\title{
MONOGRAELE LIBAE
}

TOM IV

SEARCHING

FOR IDENTHTY

Personal Experiences

and Methodological Reflections

Edited by

Ayur Zhanaev

Olha Tkachenko

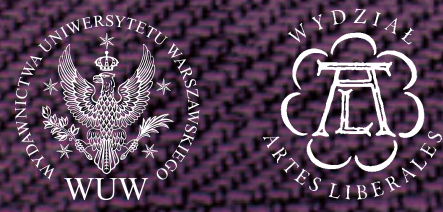


Searching for Identity 


\section{LABORATORIUM INTERDYSCYPLINARNYCH BADAŃ ARTES LIBERALES (LIBAL)}

Wydział „Artes Liberales” Uniwersytetu Warszawskiego

\section{MONOGRAFIE LIBAL}

seria pod redakcją

JANA KIENIEWICZA

TOM IV 
Faculty of "Artes Liberales"

University of Warsaw

\title{
Searching for Identity
}

\author{
Personal Experiences \\ and Methodological Reflections
}

Edited by

AYUR ZHANAEV

OLHA TKACHENKO
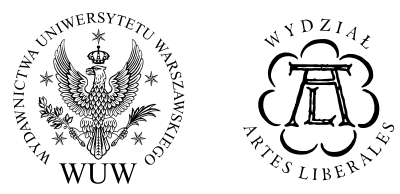

Warsaw

2021 
Reviewers

TATIANA BERNYUKEVICH

AGNIESZKA KAMPKA

Commissioning Editors

ANNA KĘDZIOREK

EWA WYSZYŃSKA

Proofreading and Editing

JAKUB OZIMEK

Cover Design

ZBIGNIEW KARASZEWSKI

Cover Photos of the Authors

AUTHORS' PRIVATE COLLECTIONS

Layout

IWONA MIŚKIEWICZ

Typesetting

DARIUSZ GÓRSKI

Published with financial support from the University of Warsaw.

Published with financial support from the "Artes Liberales

Institute" Foundation.

(C) Copyright by Wydawnictwa Uniwersytetu Warszawskiego, Warszawa 2021

(C) Copyright by Wydział "Artes Liberales" Uniwersytetu Warszawskiego, Warszawa 2021

Ayur Zhanaev ORCID 0000-0002-8976-8811

Olha Tkachenko ORCID 0000-0002-0777-7897

ISBN 978-83-235-4807-2 (print) ISBN 978-83-235-4815-7 (pdf online)

ISBN 978-83-235-4823-2 (e-pub) ISBN 978-83-235-4831-7 (mobi)

Wydawnictwa Uniwersytetu Warszawskiego

00-838 Warszawa, ul. Prosta 69

E-mail: wuw@uw.edu.pl

Online bookstore: www.wuw.pl

1st Edition, Warsaw 2021

Print and binding POZKAL 


\section{CONTENTS}

Olha Tkachenko, Ayur Zhanaev

Foreword ............................

Robert Sucharski

A Few Words in Way of Introduction ............. 15

Jan Kieniewicz

Experiences in Searching for the Identity of a Nation.......

I

INSIDER AND OUTSIDER EXPERIENCES

Daria Burnasheva

Uncovering Arcticness: Experiences of Arctic Identity at Home and Abroad ............................

Galina Dondukova

Insider, Outsider, or In-Between? The Experience of Studying the Buryat Ethnic Identity in Poland................

Ayur Zhanaev

The Falling Rain Will Stop, The Guest Who Arrived Will Leave: Once Again on "Insider" and "Outsider" Positions in the Buryat Field ............................. 


\section{CONTENTS}

\section{I}

\section{IDENTITY IN THE TEXT AND IN DISCOURSE}

Olha Tkachenko

Perceived Identity: Real Objectivity or Deconstruction of Discourse?

\section{Irina Koluzaeva}

Life Strategies in a Wartime Borderland: Problems of Identity of People "In Between" on the Eastern Border of the Grand Duchy of Lithuania during the Livonian War . . . . . . . . 137

Bato Dondukov

Virtual Reality as Fieldwork: A Study of Buddhist Communities of Russia on the Internet . . . . . . . . . . . . . . . . . . 155

\section{I I}

\section{FROM PERSONAL IDENTITY TO IDENTITY}

OF A SCHOLAR

Kyunney Takasaeva (Künnej Takaahaj)

Reflections on Name and Identity: "What Do You See in My Name?"

Wojciech Cendrowski

A Blue Collar as an Ethnographer: A Few Reflections about Ethnographic Fieldwork in the Context of the Polish University

\section{Marzena Maciulewicz}

In Search of Scientific Identity: Reflections on Intercultural Partnership, Fieldwork, and Researcher's Engagement . . . . . 229

Kamil Maria Wielecki

International and Interdisciplinary Doctoral Programs in the Polish Academic Culture - Obstacles and Opportunities: Observations of a Graduate and Coordinator . . . . . . . . . . 267 


\section{V}

\section{INTERCULTURAL COMMUNICATION}

AS A COMPONENT OF ACADEMIC CHANGE

Valeria Korablyova

Imagining a Modern Poland: Lessons for Ukraine . . . . . . 287

Oleksiy Polunin

Time Flow in the Human Mind. . . . . . . . . . . . . . . 307

Inna Sukhenko

Literary Chernobyl as a Factor of Ecological Identity Formation:

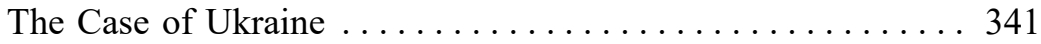

Natalia Andriichuk

Terminology in Inclusive Education: Its Evaluation in Ukraine 361

About the Authors ........................ 375 


\section{Olha Tkachenko}

ORCID 0000-0002-0777-7897

University of Warsaw; Insitute of Slavic Studies,

Polish Academy of Sciences, Warsaw

\section{Ayur Zhanaev}

ORCID 0000-0002-8976-8811

University of Warsaw

\section{FOREWORD}

This volume is dedicated to the international $\mathrm{PhD}$ program "Searching for Identity: Global Challenges, Local Traditions," organized at the Faculty of "Artes Liberales," University of Warsaw, in 2013-2018. The eponymous seminar that was at the center of this program was an excellent example of academic cooperation. For six years of its duration, the seminar was a real platform for multidisciplinary academic discussion and thoughtful insight. A logical conclusion to our seminar is the present volume, dedicated to our common research problem. The participants of our seminar pursued very diverse topics and came from diverse academic backgrounds. However, the thing they all had in common was their interests in identity, which was the core element of all our discussions and presentations during the seminar meetings.

The volume considers quite significant methodological issues. It aims at showing identity as a processual concept, 


\section{Olha Tkachenko, Ayur Zhanaev}

using the example of the researcher as a living personality. It thus corresponds with the general trend in the humanities and social sciences of paying attention to the researcher and the ways his or her personal background and experience influence the generation of knowledge. We are constantly changing and our views on identity are changing, as well. By introducing this topic, we would like to show completing a $\mathrm{PhD}$, or any other research, as a dynamic process with a personal history of success and failure, as well as to demonstrate the impact of the "Searching for Identity" project.

While working on the volume, we asked our authors not to hide behind theories and be free in defining the vague term "identity" to show their own personal and academic evolution. We also encouraged contributors to share their experience of searching for the proper methodology, and the difficulties faced by them while working on the thesis or research project.

Despite our openness to various perspectives and formal choices, the task we gave our contributors turned out to be very difficult. Many of them thought that this approach was not "scientific" enough, or were not used to writing in a such a way. While in anthropology it is not uncommon, for historians, literature studies scholars, or sociologists it was, indeed, a new perspective. Every field and every perspective introduced a new aspect, new description of identity and its dynamics. Not everybody ended up going beyond objectivism (which is not necessarily a bad thing); however, for many of the authors, the vantage point we proposed opened up a new outlook on their own work. It helped them to define their position in the 
research process, to estimate their possibilities and weaknesses, and gave them more confidence in their work.

The volume consists of fourteen chapters, an introductory word of Professor Robert A. Sucharski, Dean of the Faculty of "Artes Liberales" at the University of Warsaw, and an opening article by Professor Jan Kieniewicz, Head of the International PhD Program "Searching for Identity: Global Challenges, Local Traditions," organized in 2013-2018 at the Faculty of "Artes Liberales," University of Warsaw. Ten chapters are the texts by former participants of the $\mathrm{PhD}$ program. The remaining four were authored by the guest scholars doing their research within the Global Dialogues Fellowship at the Faculty of "Artes Liberales," funded with support from Open Society Foundations. While seemingly different, all these texts are united by the theme of searching for identity, of identity types and ways of their exploration, cognition and perception, and of personal experiences and changes on the academic path.

The first block of articles is called "Insider and Outsider Experiences." The article opening this part is Daria Burnasheva's text, presenting her own way to, and experience of, researching Arctic identity. Having been born in Yakutia (Sakha Republic), she perceives herself as an Indigenous researcher of Arctic identity, and describes all the difficulties related to it. Moreover, Daria Burnasheva shows her own way of researching Arctic identity from abroad and the ways this influenced her work as an Indigenous researcher.

The second text of this part is by Galina Dondukova, who reflects on her status as a researcher of Buryat identity in the 
poetry of Bair Dugarov. Through the lens of her own life, Galina Dondukova shows the path of becoming "three scholars in one" during her work on the $\mathrm{PhD}$ thesis. The article shows the experience of a researcher being an insider, an outsider, and a person in-between, all at the same time.

Like his colleagues, Ayur Zhanaev also presents his view on the issue of being an insider as well as an outsider during his research. Ayur Zhanaev's PhD dissertation was devoted to Buryat ideas of the social order. The author shows how being a Buryat himself helped and, conversely, handicapped him in researching his own culture, especially on the level of fieldwork.

The second part of the volume is called "Identity in the Text and in Discourse." It is dedicated to researches of identity in different time periods that used various materials which could be seen as texts opening new, broader discourses and contexts. Olha Tkachenko's article is dedicated to the notion of perceived identity. Having studied Ukrainian identity in the Polish media discourse, she shows what theoretical and methodological grounds are most suitable for research like hers, based on the sociological notion of identity, which she transfers to media studies and analyzes with the help of Critical Discourse Analysis.

Irina Koluzaeva's chapter demonstrates how identity could be researched, and what kind of identity could be researched, from a historical perspective. Her article is dedicated to people of the borderland referenced in the correspondence of Filon Kmita Czarnobylski (1530-1587) - Captain of the borderland Castle of Orsha, and the Palatine of Smolensk. Irina Koluzaeva 
shows the way historians research identity using only written texts from the given period.

A very interesting approach is to be found in Bato Dondukov's article. He researches Buryat identity but from the perspective of religion, namely Buddhism. In Bato Dondukov's case, the text that is studied is that of virtual reality - the representation of Buddhism on the Internet. The article recounts his experiences and demonstrates the methodological instruments that could be used in research of this kind.

Each text of this volume concerns the aspect of personal identity of the researcher and its changes that eventually take place during the cognition process. Three of them, however, stand out in their particular focus on the issue of personal identity of the scholar during research. We decided to bring those texts together in the third part, called "From Personal Identity to

\section{Identity of a Scholar."}

Kyunney Takasaeva's article goes deep into the roots of her personal identity while describing her research on Yakut names and surnames. Wojciech Cendrowski presents his reflexion on ethnographic fieldwork and how it changed his own identity. Marzena Maciulewicz's paper explores different aspects and components of academic identity, trying to identify circumstances which may influence significantly the shaping of a young researcher's scientific perspective. The final article by Kamil Wielecki is based on his personal experience of participating (as a student and then coordinator) in three international and interdisciplinary doctoral programs that were operating - or are ongoing - at the Faculty of "Artes Liberales," University 
of Warsaw. He goes beyond a narrowly understood personal view in order to indicate the basic pros and cons of such programs, and formulates several practical solutions that may be implemented in organizing interdisciplinary doctoral studies. The author thus comments on interdisciplinary education in the context of the contemporary labor market and refers to the place of international and interdisciplinary programs in the Polish academic culture.

The four chapters closing this volume form its final part, entitled "Intercultural Communication as a Component of Academic Change." As we mentioned, these articles showcase the academic work of four guest scholar of the Faculty of "Artes Liberales." Despite representing different fields of studies, the texts all concern particular aspects of identity. Valeria Korablyova writes about post-communist transformations in Poland and the context of Polish-Ukrainian relations. Oleksiy Polunin presents the philosophical aspect of time flow in the human mind. Inna Sukhenko's article deliberates on the Chernobyl disaster as a factor in the construction of ecological identity. Finally, Natalia Andriichuk discusses terminology in inclusive education and the problems Ukraine has with it.

We hope that the volume presented to the reader will inspire further reflexion on the fascinating subject that is identity and thereby prove a worthy commemoration of the seminar to which it owes its existence. 


\section{Robert A. Sucharski}

ORCID 0000-0001-7708-7173

University of Warsaw

\section{A FEW WORDS IN WAY \\ OF INTRODUCTION}

Cultural heritage and tradition, and the sense of identity that stems from them, have been among the fundamental research problems for the scholars associated with the Faculty of "Artes Liberales" at the University of Warsaw since the dawn of its existence. The aim inscribed already in the name of the Center for Studies on the Classical Tradition in Poland and CentralEastern Europe at the University of Warsaw (OBTA UW) - an institution established on December 19, 1991, and a predecessor of today's Faculty - required, and still requires, active efforts to establish an international network of institutions of higher education that would encompass also countries lying to the east of Poland, especially those united with it by common heritage of the Polish-Lithuanian Commonwealth (Rzeczpospolita Obojga Narodów) of the Jagiellonians and elective kings. The first volume in the working paper series Lacina $w$ Polsce [Latin in Poland], titled Między Slavia Latina i Slavia Orthodoxa [Between the Slavia Latina and the Slavia Orthodoxa], opens with an introduction by Professor Jerzy Axer, the originator and 
long-time Director of the OBTA UW, then (since January 23, 2008) Director of its successor, the Institute for Interdisciplinary Studies "Artes Liberales" at the University of Warsaw (IBI AL UW), and after the latter was transformed into the present Faculty (October 1, 2012) - its first Dean. In the introduction, we read:

The purpose of our interdisciplinary and long-term research program is to create an extensive collection of documents and literary texts written in Latin, of readings which can bring back to the national memory a set of experiences that have largely been forgotten and at the same time - to introduce into the international academic circulation knowledge about the eastern peripheries of the historically shaped community of Latinspeaking European elites. This purpose, however, can only be sensibly pursued when perceiving the Polish Latinness in a broader context of the Latinness of the entire region; what is more, we must not forget even for a moment the peculiar dialogue and confrontation between the Latin element and the world of Byzantine tradition (Axer 1995, 7-8).

By and large immediately, this idea found its reflection in the International School of Humanities (MSH). This project planned for many years ahead and still operating in a somewhat altered form - has three basic goals:

- to create a cooperative network of Central and Eastern European academic institutions;

- to popularize modern theories and methodologies in the human sciences and - above all - to offer support to young scholars representing the fields that were underrated in many countries of the region (especially the USSR), but which were and remain of crucial importance to the revival of the humanities; and consequently,

- to create an international and interdisciplinary community, capable of cooperation, and as a result - to eliminate the 
vacuum which might get filled by an ideology of primitive nationalism along with ethnocentric delusions and clichés.

To follow these premises means to educate specialists in the common history of the region, questions of cultural heritage, translation studies, linguistics, publishing technologies, archival science, classical languages, and so forth. It also means to resist the trend, predominant in the 1990s, of teaching law, economy, management and business administration, or applied social science... The MSH has remained one of the very few international programs addressed to humanists, and the only one to stress the importance of the Mediterranean tradition in the region. Now run by the Faculty, the School emphasizes the need for humanist education for the specific reason that it is such education alone that may consolidate the intellectual communities which could be leaders for the civil society and play an especially important role in promoting the national tradition and fostering historical memory, and therefore forming the public opinion in the countries of the region.

The MSH is intended for young academics, including doctoral students and people working on their postdoctoral/habilitation dissertations. The participants are selected in a competition, with candidates who come from all Central and Eastern European countries and fall into one of the following categories:

- young scholars from universities and academies of sciences who hold teaching positions or are serving teaching internships;

- researchers from archives and libraries who also teach at institutions of higher education; 
- fourth- and fifth-year students of the institutions which allow the inclusion of MSH-taught courses in their students' curricula;

- by way of exception, students of earlier years at special request of their schools' presidents (this was associated with reforms in the curricula of the humanities programs in progress at the school in question);

- by way of exception, scholars from the US and Western Europe who specialize in topics associated with Central and Eastern Europe.

The importance of this project was soon recognized, owing to which the MSH could count on financial and organizational support from both the University of Warsaw (organizing the MSH is one of the elements in the fulfilment of the Faculty's goals of offering interdisciplinary and interfield courses and research in the area of human and social sciences, including especially the broadly understood classical - Greek, Roman, and Byzantine - tradition, and is listed as such in the Faculty Rules and Regulations) and numerous benefactors from Poland, Europe, and America.

Also relatively soon, it turned out that these goals can likewise be realized by methods different from those standardly applied at the MSH - namely, by organizing short, usually month-long, sessions, during which the participants undergo intensive training under the supervision of their academic tutors; then, having returned to their home institutions, the participants carry out more or less broadly defined research tasks. Thus, on the initiative of Professor Jan Kieniewicz, within the 
Transcidiplinary Inter-Faculty Doctoral Programme - run jointly by the Faculty of "Artes Liberales" and the Faculty of History, University of Warsaw - a special module was introduced, called "Searching for Identity." The doctoral students who partook in it came from Poland, Ukraine as well as from European and Asian (Siberian) parts of the Russian Federation. The participation of students from outside Poland was made possible by the AURORA and WEBB Projects with the EU Erasmus Mundus Program.

The "Searching for Identity" Project has come to completion - it produced several excellent doctoral dissertations; this volume presents some of the works by its participants. The project's main premise was to allow the students to engage in a free dialogue in the spirit of mutual respect, which often runs counter to one's own identity. In a hierarchical world that is academia, engaging in a conversion that stems from one's sense of identity, and (a much more difficult task) being able to defend it, see it through the eyes of others, and thus allow for its potential redefinition, requires from the participants not only particular tactfulness but above all adopting dialogicality as the fundamental principle of such endeavor. Here, we come back to the general need for a humanist education that forms and consolidates intellectual communities in a given country or, more broadly, in the region and globally. The dialogical principle is especially important in the context of our region of the world, where we often find ourselves dealing with historical resentments, while ethnic, confessional and linguistic identity is perhaps the most important determinant of nationality. However, 


\section{Robert A. Sucharski}

in the peculiar context of academia, dialogicality is also important in research work: it enables one to transgress the confines of narrowly defined scientific disciplines, as it opens up the academic discussion to new methodologies and perspectives. In other words, it favors inter- and transdisciplinarity.

Given all this, the Faculty's engagement in Open Society Foundations' Global Dialogues Program is hardly surprising. Though the beneficiary of the OSF grant is its close collaborator, the "Artes Liberales Institute" Foundation (FIAL), the Faculty of "Artes Liberales" provides the participants with academic supervision as well as opportunities for academic contact. Four postdoctoral researchers from Ukraine took part in the 20 first, one-semester-long phase of the project (2016-2017), while four postdoctoral researchers from Belarus partook in the second phase (2018-2019). The program offers support to researchers who specialize in broadly defined human and social sciences and are open to interdisciplinarity and, furthermore, aware of the responsibility falling on the academic world due to its presence in society. The articles presented in this volume are meant to document also this kind of social responsibility of academia.

In a world where access to information is no longer a problem - on the contrary, what has become problematic is excess of information and the resulting need for selectiveness - a dialogical, interdisciplinary and socially responsible academic thinking is a necessity.

Translated by Jakub Ozimek 


\section{A FEW WORDS IN WAY OF INTRODUCTION REFERENCES}

Axer, Jerzy, ed. 1995. Między Slavia Latina i Slavia Orthodoxa [Between the Slavia Latina and the Slavia Orthodoxa]. Vol. 1-2 of Lacina w Polsce: Zeszyty naukowe. Warszawa: OBTA. 


\section{Jan Kieniewicz}

ORCID 0000-0002-3580-9112

University of Warsaw

\section{EXPERIENCES IN SEARCHING FOR THE IDENTITY OF A NATION}

Searching for identity has never been straightforward - not at any time nor at any place. Our doctoral program "Searching for Identity: Global Challenges, Local Traditions" did not define

a priori the concept of identity, nor the meaning of searching for it. Despite these doubts, our joints efforts and searches, discussions and disputes, proved to be helpful in building our research project. That is why for the topic of my final reflection I chose my own experience in searching for the identity of a nation, specifically the Polish nation. I wish to explain how I have reached a systemic conceptualization of the matter - and what results from it.

National identity is sometimes understood as belonging - that is, a feeling of participation within a community that is a nation. Members would thus accept their national identity from the community - regardless of whether ethnic-natural roots are posited for the nation's identity, or if the community was simply imagined. These identities are accepted and imagined in diverse ways, depending on the changing circumstances, and scientific disciplines have developed differing approaches to the matter 
(Dyczewski and Wadowski 2009; Borowik and Leszczyńska 2008). Ultimately, we encounter individual and collective, social and national, religious and cultural identities (Bokszański 1989). This multiplicity advises caution, particularly in the case of national identity, a community suspected of being both primordial and concocted. In what follows, my approach is systemic, not disciplinary. I have written about the matter many times (J. Kieniewicz 2014, 68-70), therefore I shall confine myself to the elements required to understand my intention.

A systemic conceptualization of national identity indicates its capacity to exist. At the same time, it spotlights the dialogical character of such a community. And by that I understand that the national community exists owing to decisions made by individuals who are inclined to build mutual relations and are ready to treat them as a result of their free choice. These choices coalesce into "the dialogic," that is a dialogue of contrary logics, where synthesis does not take place, and a retroactive impact continues (Morin 1987, 127). Thanks to this, the nation can be an autonomous system that clearly differs from other communities. Here I particularly underline the distinctive ability of humans to conduct dialogue (Grygiel 1982; Grygiel 1988, 33; Tischner 1992, 19-22; J. Kieniewicz 2003, 67).

Thus, I have proposed to "go beyond the cliché of stating that the identity of individuals does not combine into a whole, as it is not derivative in itself of the whole" (J. Kieniewicz 2016, 37). National identity is one matter, the nation's Identity another.

${ }^{1}$ According to Edgar Morin, "Le terme de dialogique veut dire que deux ou plusieurs logique, deux principes sont unis sans que la dualité se perde dans cette unite." 
The nation's Identity in my conceptualization refers primarily to an ability to regulate processes guaranteeing the existence of its structures and of conducting transformations. I recognize the reality of a voluntary association of free individuals assuming the preparedness to act for a common future. National identity is, in turn, an expression of affiliation, meaning the participation of the individual in a community which is able to act on behalf of the nation's existence. Poland is therefore a community of people convinced that they want to be Poles and consistent in the way of considering themselves a nation. The Poles' national identity is Polishness, resulting from an individual choice and from a sense of common duty (Lepkowski 1987).

My research experience indicates two circumstances. Firstly, nations are not universal, and there are still communities bound on different bases, creating their structures differently. Secondly, as any form of a community, nations are not eternal. Nations are formed by people convinced about their affiliation, about their will and ability to create a community. Many sundry benefits result from this, such as national pride, and individuals are ready to make sacrifices for the community understood in this way. There is a feedback loop between people and the community, yet it does not boil down to the person acquiring the ability to exist owing to affiliation to their community. Paradoxically stated, Poland cannot exist without Poles, but Poles can exist without Poland (Czapliński 2013). ${ }^{2}$

\footnotetext{
${ }^{2}$ Poles like to deny this, since they are interested primarily in excluding others from the community.
} 
The Polish nation is a historically shaped community of people considering themselves Poles. The nation's Identity is the capacity to exist as a community; it is a set of characteristic variables. I wish to present a correlation between the defense of identity and the continuation of existence even at the price of structural changes. In systemic categories, defending identity is a set of actions undertaken in order to sustain the system's structures. A change of structure requires new mechanisms controlling the changes (new transformations). In my understanding, Searching for Identity is namely the conscious effort towards sustaining existence, as well as the effort to continue existing despite structural changes. ${ }^{3}$ All of this has happened over the period of at least two centuries, in real relations as well as in concepts.

The issue of defending identity first arose for me in works on the history of India. While writing about the precolonial society of Kerala, I had to grasp the problem of the society's existence, and its ability to independently continue in rapidly changing circumstances (J. Kieniewicz 1975). I wished to imagine the continuity in circumstances of very powerful external stimuli, ones lasting for millennia. The world of the Indian Ocean was not the only thing that had impact on this society. Kerala remained in economic relations with economies spread from East Africa to China, being a country supplying others primarily with pepper (J. Kieniewicz 1989a). This had a strong impact on forming the environment, where land under food cultivation

${ }^{3}$ An extreme case is the new identity of a community resulting from an adaptation of its surviving part. 
could be limited in favor of gardens. The deficit of rice, a basis of the Malayalam people's diet, was easily complemented by import. Under the influence of intensive connections with the world overseas, Kerala society shaped itself as a "littoral oriented" one (J. Kieniewicz 1986b). The Portuguese confronted this reality, and later on so did other newcomers willing to establish their trading posts and fortresses there (J. Kieniewicz 1970). I searched for an explanation of the effectiveness in resisting foreign expansion, not only military and economic. This also concerned the civilizational pressure which had with utmost clarity revealed itself in a multigenerational conflict between the local Christians of the Syrian rite and the Roman Church (J. Kieniewicz 1990, 2001). In order to understand this case, it was not enough to simply abandon Eurocentric concepts (J. Kieniewicz 2007). The theory of systems allowed me to understand the mechanism of development that sustained these societies in equilibrium. Societies like these I defined as stationary.

Kerala was a part of the world which Europeans called India. It was not easy for me to grasp its identity as a society in a way that did not refer to European terms. Keralans had a common language, a caste social order, and lived between the ocean and the mountains. To some extent they were connected by remembering their past. They differed in religion, shared state loyalties, and had divergent interests. This was a country open to others: Jews, Greeks, Arabs, and the Chinese. Kerala in its diversity fell within something that could be called the Indian civilization, though not much else can be added here, 
since it has belonged to the united Indian state only from $1956 .{ }^{4}$ This classification is of European origin and does not mean anything more than does saying that Poland is in Europe not only geographically.

I generalized this experience. Above all, I acknowledged that the subordination of India to European dominance consisted in fact in the transformation of those societies from a stationary to a backward condition (J. Kieniewicz 1989b). On the contrary basis of India, I broadened my theoretical vision referring to all societies, not only European (J. Kieniewicz 1980a, 1980b). Eventually, this was reflected in an attempt to describe the social transformations which had happened under the influence of European expansion (J. Kieniewicz 1986a, ch. 3).

All of this has had an impact. For a long time, I focused on how the community carried out transformations, and especially on understanding the mechanisms supporting the community in sustaining its functional balance - primarily ecological balance. Only later did I give thought to how these societies lost their autonomy. I asked what happened, when did adaptational processes have to refer to foreign dominant structure? Over time, I came to the conclusion that the mechanisms determining change were crucial for existence. Hence the Transformation, known from systems theory. ${ }^{5}$ In this way, I became interested in the problems of identity as a crucial and universal category describing the

\footnotetext{
${ }^{4}$ After 1947, the Travancore Princedom and the property of the Raja of Cochin joined the Union. In 1949, they were merged with Malabar, which had remained under British governing since the beginning of the 19th century. Eventually, the Kerala state was created in 1956 on a language basis.

${ }^{5}$ Fixed Transformations were in charge of regulations and adaptations of a balanced system. New Transformations were shaped by the system adapting in a disequilibrium state.
} 
condition of any system. That is why I ultimately argued in favor of a systemic, and not, for instance, a psychological understanding of identity. One consequence of this was expanding my way of understanding and explaining all social systems.

The urge of existing, the desire to sustain the essence of one's entity - I recognized these as analogous in the case of both an individual and a community. This allowed for averting the uncomfortable question of how many members must reconcile their participation in a community in order for it to last. Perhaps this is the same perpetual problem of the inability to specify how many righteous people there had to be to save Sodom from the Creator's wrath (Gen. 18; J. Kieniewicz 2008, 241). In other words, I did not give consideration to the quantitative aspect of the individuals' willingness to create and defend the community as a national one. I remarked that social systems exceeding the scope of ethnic or local bonds, systems sustaining balance in relations with their surroundings and environment, created cultural rules of behavior that determined the way of implementing changes. In such a set of rules or models I found behaviors which were to defend the balance from constant infraction by external impulses. I called this the immunological barrier of social systems. The elements constituting it were not conservative in themselves - rather, they evinced a dynamic ability to counterbalance stimuli, allowing a reinstatement of the system's functional balance. I emphatically underlined that being stationary did not imply motionlessness, or a steadiness deprived of the capacity to develop (J. Kieniewicz 1975). That is why the identity of societies in a stationary state was not etched 
in stone, not unchangeable. It is crucial societies of this type carry out changes, including quantitative changes, using their own resources of rules and in an autonomous way. In defining them as stationary, I underlined the meaning of sustaining an ecological equilibrium and at the same time I indicated that they did not remain "behind." Progress, according to my approach, was recognized as constant imbalance. Duration meant that identity was being sustained and that the society was changing in order to exist. Survival could mean this type of adaptation, while a transformation of the system's structure signaled its new identity.

This distinctive new form was adopted by the transformation process in circumstances of aggression, which I describe as crossing the border dividing society from the environment (J. Kieniewicz 2005, 41). I compare this to the breakdown of the immunological barrier. Cases of conquest are the best known, yet other forms of external impulses aggressively barging into society have also occurred. Analyzing this phenomenon, I indicated the diversity of violence and oppression (J. Kieniewicz 2009, 20-58). A classic case of defending identity was provided to me by the history of colonial India. The British did not intend to change the social structure, yet they directly interfered in economic, ownership, state, and educational relations.

Crucially, their interferences had unexpected effects. Accepting the caste system, an attitude dictated by reason, was completely contradictory with the disgust to it commonly 
felt among Englishmen. It resulted, for example, in introducing population censuses including the caste division. The Indian tradition of the Varna division and the locally identified Jati division had never been centralized and codified in this way. The introduction of a registering system by the British had two unintended effects, and both were considered unfortunate for Indian society. It suddenly turned out that there were thousands of castes which shaped an inviolable hierarchic system. Secondly, it was acknowledged that this was a natural characteristic which had its origins in Hinduism. From my perspective, meanwhile, the proliferation and petrification of the caste system is a marvelous example of a sustainable reaction of the system facing the threat of losing its identity.

I have in mind the phenomena crucial for the system to exist; in the case of India, this concerned in particular village communities. Not states and not ethnic regions, but villages, with the local bonds relatively determined by environmental circumstances and by traditions of cooperation. These communities underwent the strongest civilizational oppression. This was one of the numerous consequences of the British conquest that proved to be completely different from the well-known experiences of aggressive conquests of Mogols / Mughal or Maratha. The oppression resulted from the overlapping of a long-lasting system of exploitation, an educational deformation, law codification, and indeed the arrangement of what earlier had been a state of nature. Village communities, or more broadly, local communities, reacted to these forms of pressure with an increasingly strong following of the binding rules of 
separation, rationing, and hierarchization. The consequence of the resistance, described as a conservatism allegedly natural for India, was the shaping of a self-fulfilling vision of an eternal stillness and incapacity to induce an independent change.

In the case of India, its conquest did not only lead to subordination: it resulted in dependency. That is why I talk about a change of the state of social systems from a stationary into a backward one. Backwardness ${ }^{7}$ was a petrification of the ecological disequilibrium without opening chances for progress. That permanent loss of the system's functional balance did not activate the mechanism of economic development; on the contrary, the efforts that were to cause the take-off resulted in 32 the petrification of dependency. Therefore, this was not only a trap of failed progress. Within backwardness I primarily notice the false promise of modernization, in the evolutionary as well as revolutionary version. One of the symptoms of backwardness is colonialism. I see colonialism as a universal phenomenon, a characteristic property of systems of subjugation, enslavement, and exploitation (J. Kieniewicz 2009a, 48; J. Kieniewicz 2014, 76). Colonialism proved to be a crucial barrier in attempts to modernize these systems as undertaken by non-European societies - also after gaining independence.

One symptom of colonialism was Orientalism, here understood as acceptation of the dominant model by the subjugated (J. Kieniewicz 1985). I have found that this can be generalized and applied to cases of pre-colonial aggressions by European

\footnotetext{
${ }^{7}$ I deliberately use this term and not underdevelopment.
} 
countries. In my concept it is crucial to indicate that this was not some kind of import, a type of a systemic stencil imposed by colonial governments. This was a specific type of submission of dependent societies (J. Kieniewicz 1992). In the second half of the 20th century, when the global world was formed, the division between the Center and the Peripheries, the West and the Rest, was established. It looks like a division between the rich and the poor, yet it does not accord with state borders or national affiliation. These divisions seem to be a subsequent interpretation of the state of dependency. Here the case of Poland proves helpful, as it is a country not associated with colonialism.

The analysis of cases where societies managed to overcome this arrangement, exit backwardness and enter a state of progress, indicates that it required a structural change, indeed a change of identity. I call this a metamorphosis. In many cases in the old Third World, this process had a dual character: a modernized sector was being shaped within society, yet the majority of society remained in a realm of poverty. Today it looks even worse, because the consequences of the domination of progress pertain to everyone's condition, and especially the biosphere's. The above descriptions of the social systems' condition, which in my opinion described the modern world in general, prove to be less helpful in the global world. Even societies having a distinctly outlined national identity have faced the problem of the globalization of their surroundings and primarily their environment. This remark applies all the more clearly to societies that have devoted the entire past century to "exiting underdevelopment." Among them to Poland. I realize 
that backwardness was referred to in a different, economic sense. It needs to be remembered that it extended to technically all areas of life. My conceptualization of the backward state perfectly embraces these attempts at description. I believe that it explains things better. Yet globalization, and primarily the related ecological crisis, changed the most important parameters of my comprehension. It may prove that the relations between societies and ecological niches have become significantly distorted because of the following changes in the biosphere.

Old Indian communities were not nations, nor are all states in today's world national. The view that non-national communities are in decline predominates. Despite not taking up this topic, I nevertheless wonder: what other shape will be adopted by communities? All the more so in circumstances of generalizing dependencies and the spread of ecological disequilibrium, matters impossible to control with known resources. People speak negatively about nations because of conflicts and nationalisms which threaten national safety, particularly when facing mass migration. I consider nations as exceptionally favorable forms of communities, yet I know that this form will have its end. But first of all, I am interested in the question: which Poland is the Polish nation?

We believe in one, constant, and everlasting Poland. And yes, a Poland undergoing differing phases, but for a millennium a Poland organizing our common identity, and basically considered national. As every belief, this one also has practical consequences. One of them is the cognitive dissonance between the idea and the experience. This concerns understanding the 
continuity of the national entity in times covered by our memory. The past as such is inaccessible to one's own experience, and the mediated past is often constructed, imagined, belied, basically adapted to momentary needs. The things we know personally are harder to subject to manipulation.

Regardless of faith, we are faced with reality: social structures, state organizations, managing models, and the thing we consider the national character (not particularly accurately). When experiencing the dissonance of imagination and reality, we conduct various adjustment procedures. One of them is reconstructing the past. Another is projecting the future. The question recurs: can Poland, understood as a collectivity considering itself a nation, be described in categories of defending identity? In my opinion it can, and even must. I refer, first, to the post-partition period of Polish history.

The partitions erased the Rzeczpospolita, as Poles speak of their onetime Commonwealth, from European reality for over one hundred years. Let us add that for the antecedent century it had been deeply dependent on Russia, and in the opinion of Europeans, it belonged to Eastern Europe. ${ }^{8}$ Hence the conviction that the anarchic and anachronistic Poland is likely a periphery of the civilized world that can exist without Poland. This state of affairs was consolidated by the Treaty of Vienna in 1815. The arrangement proved to be effective, as was demonstrated by the last century. Versailles and Yalta will remain the century's symbols. However, people remained who considered

\footnotetext{
${ }^{8}$ In essence, not Europe. This is a euphemism which with time served the identification of the West (as opposed to the East) with Europe.
} 
themselves Poles, who made the regaining of Polish lands a requirement of their identity. ${ }^{9}$ Poland also remained as a symbol, an idea, and finally an aspiration. Besides, for several generations, Lithuania and Ukraine remained in Poles' memories. ${ }^{10}$ This is not the place to determine what the Rzeczpospolita was as a system (cf. J. Kieniewicz 2013a, 2013b). Yet it behooves us to underline that it constituted a political version of the civilizational project of the szlachta, the noble citizens of the old Rzeczpospolita, and from this project several Polish generations derived their basic source of tradition.

It is difficult to consider in these circumstances the functioning of defense mechanisms recognized in my Indian research. Can the Rzeczpospolita as a system be recognized as a stationary form? Similarly to India or modern Europe, the Rzeczpospolita combined many ecosystems. In certain areas language, cultural, and religious differences shaped separate communities. The Rzeczpospolita represented a whole for the szlachta estate, which in itself was very diverse. It was a common matter, an idea and a term, a political and legal reality, a net of neighborhoods and clientelist relations (Mączak 1993). For the noble citizens who formed it, it was also the Motherland, one very specific, albeit diverse in its landscape. It did not create an empire, neither did it become a separate

\footnotetext{
9 "Będziem Polakami" (We shall be Polish) was a call indicating the necessity of regaining authority over Polish lands.

${ }^{10}$ Also after 1945. I remember the Christmas Eve of 1944 and singing the carol Stary wiarus, which includes the lines: "W Betlejem się rodzi maleńka dziecina, będzie wolna Polska, Litwa, Ukraina..." ("A small child in Bethlehem is born, "twill be a free Poland, Lithuania, and Ukraine tomorrow morn..."). This 19th century lyric, though repeated thoughtlessly, had meaning to people who awaited the end of the war and the reinstating of order...
} 
world-system. ${ }^{11}$ This variant of the European civilizational project was created on the border of worlds. We can talk about the identity of the Rzeczpospolita for instance in the period subsequent to the Polish-Lithuanian Commonwealth, when it was named Res Publica utriusque nationis, and we can talk about the identity of Poles of that time, yet by no means in categories like those arisen in national states. Viri Poloni constituted a political nation, natio.

The affiliation of people of different estates to the Rzeczpospolita was not evident for the nobles, and above all it was understood as coming in different degrees. The structures of authority, principles of law, and economic relations pertained to all, even if exceptions were made, like the separateness of Lithuanian statutes, or a certain legal autonomy of the Jews (Goldberg 2012; Cieśla 2016). Religion, language, and culture bonded groups aware of their separateness. Ownership relations and the range of freedom divided people who were otherwise closely bound. However, estate prejudices and mythologies of provenience constituted a whole whose range of impact was very diverse. For educated people, for instance in the Latin language, this whole thing became more and more Polish with time. And the idea of the Motherland was understood locally up until the collapse of the Rzeczpospolita.

Neither generally nor locally do I undertake an estimation of the condition these societies were in. Ascribing them stationarity

\footnotetext{
${ }^{11}$ I do not mean empire understood colloquially, as it was presented, for example, by Michael Morys-Twarowski in Polskie Imperium. Wszystkie kraje podbite przez Rzeczpospolita (Polish Empire: All the countries conquered by the Rzeczpospolita), but rather a type of authority and a developmental tendency as it was recognized by, for example, Immanuel Wallerstein.
} 
without a solid study of all cases seems risky. The categories of backwardness or progress do not, in turn, seem adequate. Therefore, I limit myself to assuming that at least in the Crown of the Kingdom of Poland during the time when the kingdom was being shaped from the 14 th to the 16 th centuries, tensions related to imbalance were building up and the rules of recovering balance were established. We can talk about stationarity at least in this case. I assumed that Poland, as just the Crown, was being formed in a great vortex which encompassed people of all proveniences and affiliations around the Baltic-Black Sea axis (J. Kieniewicz 2017). And one of the consequences was the shaping of the monarchy in a mixed formula based on the belief that lex est rex. Even if today we can define the identity of the Rzeczpospolita, this does not mean that it was a nation's identity. However, we can acknowledge that in the understanding of the enlightened reformers (Krasicki, Naruszewicz, Wielhorski), the nation was the community of Poles accepting responsibility for the state and for its collapse.

It is even more difficult to determine the condition of societies torn apart by partitions, ascribed to several very divergent state organisms. We are talking about four regions which were considered by Poles as Polish. Those were societies shaped in the lands of the old Rzeczpospolita and on the basis of its personal and cultural resources. However, they were subject to very diverse treatment which in time resulted in different survival strategies. In the lands incorporated into Russia as its western governorates, Poles, being the minority, could not withstand Russification. From the second half of the 19th century they 
called those lands Kresy, which means "borderlands," underlining the defensive character of their position. Other Polish lands under Russian rule were recognized as the Kingdom of Poland, or Congress Poland, after the Congress of Vienna. They were inhabited by a Polish and also Jewish population. It was a land that uprose twice to wrest its freedom, and for both subsequent losses it paid with blood and treasure. Poles in Galicia, as the lands under Austrian rule were called, lived for generations enshadowed by the peasant revolt against the Polish szlachta in 1846. The population which used the Polish language, mostly Catholic, in the partition's eastern part coexisted in an escalating conflict with the predominantly Orthodox population which used the Ukrainian language. The Prussian partition, ethnically the most homogenous, confronted very strong Germanization pressure (Tilse 2011; Holste 2017). No national future was envisioned for the inhabitants of these lands, in any of the four cases. After regaining independence in 1918, the undertaken integration of lands, people, economies, could not - for a host of reasons - mean reinstating the old entity.

Nevertheless, a century after Poland was partitioned, the nation arose. The conviction about its existence was not at once common, let alone understood and accepted by everyone. The national concept, as formulated by the greatest of Poles: Niemcewicz, Lelewel, Mochnacki, and Mickiewicz, was a Romantic one. They expressed themselves in opposition to reality, where nationality had to be connected to the idea of a modern state (Serejski 1977). It needs to be understood that after one hundred years all the partitions had different traditions 
and customs. Also local patriotisms. What is most important, all those systems, though to a different extent, were affected by the formation taking place in states having other nationalities than Polish. At the same time, because of dependency and lack of autonomy, these systems did not create separate Polish political communities in the invaders' states. Embroiled in varying conflicts on ethnic and national grounds (with Germans, Ukrainians, Jews, Lithuanians, and Belarusians), they referred to the imagined community of Poles. While all, consciously and unconsciously, referred to Poland, not all understood it the same way - even when the poets' words bonded them above divisions, whether it was Słowacki's or Lechoń's words. Therefore, it is impossible to define these systems as distinct, as they were not fully determined. And furthermore, they did not shape Poland jointly, because Poland remained just in the realm of the Word. Its eruption in 1918 was treated as a miracle of resurrection, yet it would be more appropriate to compare it to the act of creation.

The crucial difficulty in adapting my idea to Polish postpartition history lies indeed in the lack of specification of the relation between society and the environment. With the liquidation of the Rzeczpospolita, not much seemingly changed; all the people remained where they were. However, the ownership relations, legal systems, administration, and education were distinct in each partition and this caused a far-reaching difference of societies, where language and religion remained the same. Poles under the partitions, deprived of sovereignty, did not create autonomous relations in their own circles, 
as they were in circumstances analogous to colonial. That is why their defense strategies, ones in fact causing dependency and underdevelopment, did resemble colonialism in many ways (S. Kieniewicz 1987; J. Kieniewicz 2009).

First of all, what is striking is the ineffectiveness of this defense and its false interpretation. The point is that conservative attitudes, the kind cherishing customs and home virtues, so natural for individuals living under foreign authority, proved to be hardly useful for sustaining a national community. Against convictions to the contrary, defending language, religion, and ownership was not enough. The civilizational oppression forced on Poles a certain minimalism, obscured by the pathos of slogans like "every doorstep will be a fortress for us." The problem of the dependent society consisted in the necessity of drawing on foreign structures in its own transformations. The oppression manifested itself in imposing foreign behavioral models where it was hard for the oppressed society to work out its own models due to the lack of territory. This "dependency in the environment" made it harder to construct answers to its challenges. "The longest war in modern Europe" was fought by Poles in the Prussian partition under the rule of law, yet they accepted confrontation in circumstances which had been imposed on them. This did not afford any chances for the nation. Under Russian rule, people looked for modernization models in the West, yet applying them was limited, not only because of the lack of capital but also because Poles lacked independence in decision-making. In both cases the initiatives and ambitions could be fulfilled only in imperial structures. Making use of them 
for national purposes was limited. ${ }^{12}$ Eventually, the Bolshevik Revolution destroyed the resources which remained in Polish hands, and it was difficult to tell whether there was any alternative for Poland in "white" Russia, either (Zarycki 2016, 126). The Austrian partition, after the Ausgleich agreement in 1867, gradually gained autonomy, becoming the "Polish Piedmont," giving a chance for Polish education and participation in politics, yet it did not offer prospects for modernization. Still, we have to remember about how in the "wretched" Galicia national forms developed among the peasants, who had not that long before genuinely considered themselves "imperial." Finally, we have to say that this inertia could not have been overcome by any individual, nor by spectacular successes in management of noble property, nor in industrial plants.

All of this combined for Polish backwardness and a dramatic sense of lacking prospects.

The nation, therefore, had to be invented, and this consolidated the conviction of its eternal lastingness, in order to attract the People to it. On the way to modernity, the "social issue had to be solved," and in defiance of circumstances, the economy had to be modernized. This required a revolution. ${ }^{13}$ Meanwhile the defense of Polishness consisted in defending the status quo. This is how a paradox formed, the defense of identity had to lead to searching for a new identity for the nation (Bendix 1977). Poets knew about this. Art was to replace capital: literature,

\footnotetext{
${ }^{12}$ This was a crucial thread of positivistic literature, fighting for Polishness, land, and the talents of the people working in partitioned Poland.

${ }^{13}$ This dilemma constituted the foundation of Polish thought during the partitions.
} 
music, and painting became tools used to shape the nation. This patriotic servitude weighed on artists, who often "lacked means even for bread crusts." ${ }^{14}$ Winning souls did not translate into appanage. Another far-reaching consequence of this defense was Polonization engendered by Catholicism. The bond of religion with national identity was only one of the elements of this process, which stretched back for over a century. In my opinion, the saturation of religiousness with patriotic, and over time nationalist, elements is more crucial. This fusion, so emphatically expressed in 1979 by John Paul II on Victory Square, during his homily in Poland's capital, Warsaw, had an undercurrent of monopolizing Christ by the Polish nation (J. Kieniewicz 1985). This interpretation is possible when we grasp this process in a dialogic perspective. The nation as a system is an actual bond of people, and the form it adopts makes up an integral part of the social system's structure.

Searching for identity has two elements. It is a pursuit towards expressing a common sameness, where the concept of continuity tries to hide the necessity to constantly regulate and even adapt. However, it is also a state of consciousness where the need of change is noticed, internalized, and becomes a program. Thus, the current called the modernization program formed (Kizwalter 1991) at the same time that the program of sustaining tradition was being formulated. They remain interlocked to this day. The second half of the 19th century made this clear in a dramatic way. It of course came down to 
the People who were to become the Nation wanting to accept this interpretation fused from contradictions.

The dispute over who and how would lead the transformation was led throughout the whole period of captivity, and obscured the process whereby the modern Nation was being shaped. Additionally, we realize that in subsequent generations we give this process a new form, or just a re-interpretation. Importantly, the conceptions of it also changed in relation to who was speaking out (Pąkciński 1994, 141). The process of forming the nation, inventing a new identity, was undertaken by the Polish intelligentsia (Jedlicki 2008, 219-43), which invented and fulfilled itself in this process. The intelligentsia also was to be rejected by the nation, or rather the nation allowed it to be deprived of voice (J. Kieniewicz 2009). In the role of determining the parameters of Polishness it was admittedly hard to replace, yet the Polish nation has its own way of self-appraisal.

How did searching for identity proceed in this case? Can it be considered as a stage of the system's evolution that did not defend itself, suffered a catastrophe causing backwardness, and in consequence a forced change of identity? In pondering this, we are willing to consider that the "life" of Poles, that is worshipping Polishness by a certain group of people, is the same as sustaining the identity of the system. We do not accept the rupture of continuity and the adaptational changes that caused new coordinates of Polishness. In a word, aware of the necessity to search for identity, we reconcile ourselves to maintaining the fiction of continuity, we defend outdated forms and we perpetuate national mythology. This had indeed united 
the emigrants divided by borders, free Poles, but ones cut off from the Motherland. The question looms: how did it happen that mythology came to be taken as historical truth?

In conditions of the lack of statehood, defending identity meant that one of the factors uniting people became the project for the future itself. Surely it was variously formulated, but the effort to transform an idea into a community and thereby uphold Polishness - this was a requirement for forming a modern nation. ${ }^{15}$ The remarkable effort made in the endeavor to preserve Polishness brought wonderful literature, influenced social transformations, and in every generation, it ended up with the catastrophe of an independence uprising. The price of the stubbornly persisting Polishness was very high (Łepkowski 1989). It proved to be in the way of modern thinking about the nation where traditions of a multicultural political nation had to be abandoned. This new way of thinking became nationalism. It was accepted so easily that it gained support in a deeply rooted defense system.

Yet we have to ask the question about the repercussions of these pursuits to endure against everything. The challenge consisted in the question: was being Poles enough to sustain Poland? In other words, was it about whether the nation could survive without statehood and land, or rather if the nation could arise in such circumstances? It was such a peculiar case in history that following 1918 Poles by their own will and common

\footnotetext{
${ }^{15}$ Messianic projects were not completely detached from the positivistic ones, all of them assumed working through and transforming Poles into a community capable of restoring the Motherland, that is, to unite the lands by uniting the estates.
} 
effort gained their own state. It is not crucial here whether the promises made then and the hopes put in them were fulfilled. The point is that the new identity was that of the nation of Independent Poland.

From the perspective of 1918 it seemed that the intelligentsia's educational effort and peasant aspirations bore fruit in the form postulated by generations of people fighting for independence. Class conflicts, cultural differences, people's pettiness and greatness, all of this gave way to the shared feeling of success. Yet it was often only a feeling of being "happy to regain a dumpster" (J. Kieniewicz 2012, 111). It also seemed that the guarantee of the regained state would be the nation. In its name the poet assured that the "account of wrongs" would remain an internal issue and that the state was an indisputable value. This was to prove a delusion. From the perspective of the year 2018 we can say that the national community reconstructed after 1918 found its new identity. It can be considered a state identity, yet one third of Polish citizens did not feel committed to Polishness. Disputes regarding Polishness persisted, taking on sharpness in step with Poles embracing nationalism. The ideology of the Polish National Democratic political party arose at the turn of the 19th and the 20th centuries as a defense movement having a clear project for the nation's and state's identity. In the II Rzeczpospolita, i.e., in the interwar period, that ideology did not rule the country, yet it proved to be the most durable. This resulted primarily from a successful connection of the pursuit to give the nation a new identity with the slogan of defending identity from a threatening internal danger. 
The drama of defeat in 1939 showed a significant progress of such a national identification as its ideological underpinning.

The nationalism of the 20th century was one of many ideologies. However, it needs to be underlined that it proved to be incredibly effective in mobilizing the masses. It also had the ability to take over other ideological movements to form extremely radical currents like the national socialism or national communism (Zaremba 2001). The dispute over the nation's leadership loomed over the fight over authority in the state regardless of the ideological orientation, rightist or leftist. Combining the defense of the nation with the vision of its new, in principle dominant, future identity led to a total character of connections. In Poland's case, it proved to be extremely dangerous for the nation's identity.

The nation's first problem in a multinational state turned out to be the conflict over regained lands. The nation took ownership of the land and on this basis it struggled to build relations with the People. There was a certain problem with the fact that the intelligentsia did not usually have anything yet they undoubtedly contributed to the broadening of the love for the land of Poland. However, so long as Polish lands were ruled by others, conflicts were located primarily in the sphere of imagination. After 1918 the native land, although truncated in reference to aspirations, was fought for by the armed nation. When it was taken "by sword," the nation could boldly talk about the fulfilment of its ancestors' postulates. Nonetheless, it turned out that the Motherland had to be shared with other nations. During the time of captivity Poles were focused on 
educating the People about their national, meaning Polish, identity. They did not acknowledge the other, non-Polish national aspirations of their fellow inhabitants. This caused conflicts with Ukrainians in Galicia, over Vilnius with Lithuanians, the issues of plebiscites in Silesia and Mazury with the Germans. There was also a clash with Jewish national aspirations and with nationalist resistance against assimilating them (Wasserstein 2012). People proceeded to build the state from the foundations, at the same time making this a search for the nation's identity. Defending territory, demarcating borderlines, uniting the state organism and its organizing would have been unthinkable without the presumption that it was happening in the name and for the sake of the nation. The conflict over native land was inscribed into the nation's identity.

Since then, the Polish state has continued despite several ruptures. However, Poles had to adjust their Motherland to the new lands. This happened for the first time after 1918, when the lands were regained, and then again in 1945, when lands were conferred by the Soviet Union. Poles expelled from prewar Poland's eastern lands and obtaining western lands after World War II found themselves in their Motherland alone with their opinions, unlike before the war. They perceived this new reality variously, because ethnic unity contradicted the centuries old heritage of diversity. However, the belief about the positive character of the accordance of national identity with the identity of the nation prevailed.

Looking from today's perspective, we are aware that the new identity of the nation after 1945 was not only a derivative of 
the territorial reallocation and the equally radical change of national relations. An equally crucial factor compelling the search for identity was the revolution of 1939-1945 (Leder 2014). A revolution destructive to some, and to others not satisfactory, although it brought them benefit. Paradoxically, the consummation of the revolution's fruit and the related satisfaction did not occur until the 21st century.

The shock of war and defeat, change and revolution, caused an exacerbation of defensive activity. The Poles were, as in colonial India or in partitioned Poland, deprived of the crucial element of statehood. Or actually the agency of statehood, the possibility of constituting not only laws, but also rules of behavior. After the war, the Polish state was not democratic, and the working methods intended to stabilize the regime even more severely violated the system's structure (Zaremba 2012). In these circumstances, establishing the Stalinist terror and the transition to the administrative command-economy model was accepted perhaps not with relief, but with helplessness. The phase of searching for identity had begun, and Poles became divided. After all, many supported the new reality, though not necessarily approving of it. The ones resisting, militarily and politically, were massacred. After 1956, when the communist regime underwent a "thaw," the majority accepted their fate, knowing that international arrangements did not offer any chance to openly express what type of regime the new state should have. It is not possible to unambiguously determine the nation's identity, not only during the revolution, but also in the subsequent decades. "The whole nation is rebuilding its 
capital," "The party's program is the nation's program" - these were the official slogans, used despite the constantly repeated declaration of being on the way to socialism. The nation had sworn its "Jasna Góra" Catholic vows, and all the political powers referred to it, including WRON, the military organization which introduced Martial Law in 1981. Against official declarations, in the People's Republic of Poland, people treated nationalism with understanding. In this "pretend-state" at issue was who would gain control over the nation without allowing it to emancipate itself (Eisler 2018). It seemed as if the thought of searching for identity was not allowed, and attempts were made to convince the nation about the accordance of the present with tradition. Paraphrasing the official thesis, People's Poland was to be socialist in form and nationalist in content.

This accordance was to a large extent an illusion. National identity was recognized as a sacred resource of Poles' characteristics, threatened by the aggression from the west and the east. It seemed that the submission to authority and the awareness of no alternatives would persuade Poles to accept this option. To agree with the Situation (J. Kieniewicz 2012, chs. 3, 7). From the perspective of the nation's identity it is noticeable that this illusion carried a real threat. Various people and circles gave expression to this. The Poles following the national movement and the ones undertaking independent ideas did not have a common language. Yet for all, the same issue arose as in the century of captivity: would the nation survive when adopting defensive stances?

In the second half of the 20th century searching for identity more and more blended in with the defense of the nation. 
This resulted from two new circumstances that were absent in the nation-creating process in the previous century. The first was the Holocaust, and the second was communism.

From the perspective of the nation's identity, the Holocaust meant not only the physical elimination of neighbors, but also exterminating Jews from the common memory. In turn, communism, also in the pragmatically adjusted version of "real socialism," changed not only social and production relations, it also changed mentality. All of this accumulated in phenomena responsible for changes (transformations) and in their banishing from consciousness by petrified defense processes similar to those that took place under colonialism. As a result, the regaining of sovereignty after the political change of 1989 was not able to ensure the effectiveness of the New Transformations. More importantly, it is none other than these, not fully recognized, processes that falsified consciousness. Thirty years after having pointed out the weakening national bond (J. Kieniewicz 1987), I have the feeling that defense mechanisms paralyze the pursuits which can lead to metamorphosis.

The conclusions resulting from these deliberations are not unambiguous. Searching for identity is always an attempt to, more or less consciously, stop the process of the system's degradation which leads to catastrophe. The defense of existence is a natural preservation mechanism of systems, thus the Polish nation did not particularly stand out in this regard - including when it comes to Poles' attitudes towards their own past and their willingness to build identification illusions. The problem, as it seems, is that in these defense mechanisms illusions erupt 
that alleviate the feeling of threat and, therefore, falsify reality. In the case of Poland, we can also recognize that defense mechanisms, like an immunological barrier of sorts, have succumbed to degeneration, becoming a part of an addictive system. Hence the paltry readiness to find solutions radically changing the rules of performing changes. In current attempts at searching for identity, the Polish nation has continuously been limited by an emotional attachment to defensive experiences.

\section{REFERENCES}

Bendix, Reinhard. 1977. "Tradition and Modernity Reconsidered.” In Reinhard Bendix, Nation-Building and Citizenship: Studies of Our Changing Social Order, 361-423. Berkeley: University of California Press.

Bokszański, Zbigniew. 1989. Tożsamość - Interakcja - Grupa: Tożsamość jednostki $w$ perspektywie teorii socjologicznej [Identity - interaction - group: Individual identity in sociological theory]. Łódź: Wydawnictwo Uniwersytetu Łódzkiego

Bokszański, Zbigniew. 2008. Tożsamości zbiorowe [Group identities]. Warszawa: PWN. Borowik, Irena, and Katarzyna Leszczyńska, eds. 2008. Wokół tożsamości: Teorie, wymiary, ekspresje [On identity: Theories, dimensions, expressions]. Kraków: Nomos.

Cieśla, Maria. 2016. "Żydzi a Rzeczpospolita” [Jews and Rzeczpospolita]. In Adam Michnik, Agata Bielik-Robson, and Przemysław Czapliński, My i Oni: Społeczeństwo nowożytnej Rzeczpospolitej wobec państwa, edited by Wojciech Kriegseisen, 259-85. Warszawa: IH PAN.

Czapliński, Przemysław. 2013. "Horror polonicus.” In Kim sa Polacy, 96-123. Warszawa: Agora.

Dyczewski, Leon, and Dariusz Wadowski, eds. 2009. Tożsamość polska $w$ odmiennych kontekstach [Polish identity in various contexts]. Lublin: Wydawnictwo Katolickiego Uniwersytetu Lubelskiego.

Eisler, Jerzy. 2018. Czterdzieści pięć lat, które wstrząsnęty Polską: Historia polityczna 1944-1989 [Forty-five years that shook Poland: Political history 1944-1989]. Warszawa: Czerwone i Czarne.

Goldberg, Jakub. 2012. Żydzi w społeczeństwie, gospodarce i kulturze Rzeczypospolitej szlacheckiej [Jews in society, economy and culture of the nobles' Republic]. Kraków: Polska Akademia Umiejętności.

Grygiel, Stanisław. 1982. "Naród i kultura" [Nation and culture]. Znak 329: 163-66. 


\section{EXPERIENCES IN SEARCHING FOR THE IDENTITY OF A NATION}

Grygiel, Stanisław. 1988. "Wypowiedź w dyskusji o dialogu i jedności Europy"

[An opinion in the discussion on the unity of Europe]. Znak 394: 33-35.

Holste, Karsten. 2017. "Reform from Above and Politics from Below: Peasants in the Prussian Partition of Poland." In Imaginations and Configurations of Polish Society: From the Middle Ages through the Twentieth Century, edited by Yvonne Kleinmann et al., 217-37. Göttingen: Wallstein Verlag.

Jedlicki, Jerzy. 2008. Błędne koło 1832-1864 [Vicious circle 1832-1864]. Warszawa: Neriton.

Kieniewicz, Jan. 1970. Faktoria i forteca: Handel pieprzem i ekspansja portugalska na Oceanie Indyjskim $w$ XVI wieku [Factory and fortress: Pepper trade and Portuguese expansion in the Indian Ocean in the 16th Century]. Warszawa: PWN.

Kieniewicz, Jan. 1975. Kerala: Od równowagi do zacofania [Kerala: From equilibrium to backwardness]. Warszawa: Wydawnictwa Uniwersytetu Warszawskiego.

Kieniewicz, Jan. 1980a. "Indie jako społeczeństwo stacjonarne (okres przedkolonialny)" [India as a stationary society (pre-colonial period)]. Przeglad Orientalistyczny 3 (115): 221-32.

Kieniewicz, Jan. 1980b. "Indie jako społeczeństwo zacofane (okres kolonialny)” [India as a backward society (colonial period)]. Przeglad Orientalistyczny 4 (116): 307-17.

Kieniewicz, Jan. 1985. “Orientalizm: Idea kształtująca rzeczywistość” [Orientalism: An idea shaping reality]. Przeglad Orientalistyczny 1-4 (141-144): 9-29.

Kieniewicz, Jan. 1986a. Od ekspansji do dominacji: Próba teorii kolonializmu [From expansion to domination: An attempt at a theory of colonialism]. Warszawa: Czytelnik.

Kieniewicz, Jan. 1986b. "Pepper Gardens and Market in Precolonial Malabar." Moyen Orient \& Océan Indien 3: 1-36.

Kieniewicz, Jan. 1987. “Zagrożenia polskości” [Threats to Polishness]. In Nurty życia społecznego: Studium kultury chrześcijańskiej, 82-91. Warszawa: Kościół św. Trójcy w Warszawie.

Kieniewicz, Jan. 1989a. "Ocean Indyjski jako problem” [The Indian Ocean as a problem]. Przegląd Historyczny 80 (4): 651-71.

Kieniewicz, Jan. 1989b. “Tradycja, modernizacja i kształtowanie się świadomości państwowej w Indiach" [Tradition, modernization and the shaping of state consciousness in India]. In Narody: Jak powstawaty i jak wybijaty się na niepodległość?, edited by Marcin Kula, 375-87. Warszawa: PWN.

Kieniewicz, Jan. 1990. "Szukając chrześcijan w Kerali” [Looking for Christians in Kerala]. Przegląd Powszechny 12: 409-30.

Kieniewicz, Jan. 1992. "Periphery and Backwardness: An Essay in the Interpretation of Colonialism." In 17 Congrès International des Sciences Historiques (1990), edited by Eloy Benito Ruano and Manuel Espadas Burgos, vol. 2, 771-79. Madrid: Comité Español de Ciencias Históricas.

Kieniewicz, Jan. 2001. "Cristaos e especiaria: The Portuguese Impact on the Malabar Christian Community." In The Portuguese, Indian Ocean and European Bridgeheads 1500-1800: Festschrift in Honour of Prof. K. S. Mathew, edited by Pius Malekandathil and Jamal Mohammed, 119-32. Tellicherry: Fundação Oriente. 


\section{Jan Kieniewicz}

Kieniewicz, Jan. 2003. Wprowadzenie do historii cywilizacji Wschodu i Zachodu [Introduction to the history of civilizations of East and West]. Warszawa: Wydawnictwo Akademickie "Dialog."

Kieniewicz, Jan. 2005. "Borderlands and Civilizational Encounter." Memoria y Civilisación: Anuario de Historia 8: 21-49.

Kieniewicz, Jan. 2007. "Contact, Conquest and Colonialism on the Malabar Coast." In Theatrum Mirabiliorum Indiae Orientalis: A Volume to Celebrate the 70th Birthday of Professor Maria Krzysztof Byrski, edited by Monika Nowakowska and Jacek Woźniak, 45-58. Warszawa: Elipsa.

Kieniewicz, Jan. 2008. "Polskość po przejściach" [A post-transitions Polishness]. In Jan Kieniewicz, Ekspansja, kolonializm, cywilizacja, 226-43. Warszawa: DiG. Kieniewicz, Jan, ed. 2009. Silent Intelligentsia: Study of Civilizational Oppression. Warszawa: Instytut Badań Interdyscyplinarnych "Artes Liberales."

Kieniewicz, Jan. 2011. "Intelligentsiia i imperiia" [Intelligentsia and the Empire]. Ab Imperio: Studies of New Imperial History and Nationalism in the Post-Soviet Space 1: 131-62.

Kieniewicz, Jan. 2012. Wyraz na ustach zapomniany: Polskiej inteligencji zmagania z Ojczyzna [A forgotten word on the lips: The Polish intelligentsia struggling with the Homeland]. Warszawa: DiG.

Kieniewicz, Jan. 2013a. "Eurosarmacja: O Europie Środkowej z perspektywy cywilizacyjnej" [Eurosarmatia: About Central Europe from a civilizational perspective]. Kwartalnik Historyczny 4: 817-23.

Kieniewicz, Jan. 2013b. "The Eastern Frontiers and the Civilisational Dimension of Europe." Acta Poloniae Historica, 107: 165-75.

Kieniewicz, Jan. 2014. "Ekohistoryk wobec wyzwań przyszłości” [An ecohistorian facing future challenges]. Przegląd Humanistyczny 1: 65-80.

Kieniewicz, Jan. 2016. "Poszukiwanie tożsamości w procesie transformacyjnym" [Identity search in the transformation process]. Przeglad Humanistyczny 2: 29-39.

Kieniewicz, Jan. 2017. "The Jagiellonian Idea and the Project for the Future.” Politeia 51: 5-25.

Kieniewicz, Stefan. 1987. "Jak być Polakiem pod zaborami” [How to be Polish under the partitions]. Znak 390-391: 35-43.

Kizwalter, Tomasz. 1991. "Nowatorstwo i rutyny”: Spoleczeństwo Królestwa Polskiego wobec procesów modernizacji (1840-1863) ["Innovation and routines": Society of the Polish Kingdom and modernization processes (1840-1863)]. Warszawa: PWN.

Leder, Andrzej. 2014. Prześniona rewolucja: Ćwiczenia z logiki historycznej [A wakingdream revolution: Exercises in historical logic]. Warszawa: Wydawnictwo Krytyki Politycznej.

Łepkowski, Tadeusz. 1987. "Myśli o historii Polski i Polaków” [Thoughts about the history of Poland and Poles]. In Tadeusz Lepkowski, Rozważania o losach polskich, 83-154. Londyn: Puls.

Łepkowski, Tadeusz. 1989. Uparte trwanie polskości: Nostalgie - spory - nadzieje - wartości. [Persistence of Polishness: Nostalgies - disputes - hopes - values]. Londyn: Aneks. 


\section{EXPERIENCES IN SEARCHING FOR THE IDENTITY OF A NATION}

Mączak, Antoni. 1993. “Jedyna i nieporównywalna? Kwestia odrębności Rzeczypospolitej w Europie XVI-XVII wieku" [Unique and incomparable? The issue of the separateness of the Rzeczpospolita in 16th-17th century Europe]. Kwartalnik Historyczny 4: 121-36.

Morin, Edgar. 1987. Penser l'Europe [Thinking Europe]. Paris: Gallimard.

Pąkciński, Marek. 1994. Konserwatyści na rozdrożu: "Młodzi konserwatyści” warszawscy wobec ideowych dylematów schyłku XIX wieku [Conservatives at the crossroads: The Warsaw "young conservatives" in the face of ideological dilemmas of the late 19th century]. Warszawa: Instytut Badań Literackich PAN.

Ścigaj, Paweł. 2012. Tożsamość narodowa: Zarys problematyki [National identity: An overview]. Kraków: Księgarnia Akademicka.

Serejski, Marian Henryk. 1973. Naród a państwo w polskiej myśli historycznej [Nation and the state in Polish historic thought]. Warszawa: PIW.

Tilse, Mark. 2011. Transnationalism in the Prussian East: From National Conflict to Synthesis (1871-1914). New York: Palgrave Macmillan.

Tischner, Józef. 1992. Etyka solidarności oraz Homo sovieticus [Ethic of Solidarity; Homo Sovieticus]. Kraków: Znak.

Tomasiewicz, Jarosław. 2012. Rewolucja narodowa: Nacjonalistyczne koncepcje rewolucji społecznej w Drugiej Rzeczypospolitej [National revolution: Nationalist concepts of social revolution in the Second Polish Republic]. Warszawa: Europejskie Centrum Analiz Geopolitycznych.

Wasserstein, Bernard. 2012. W przededniu: Żydzi w Europie przed druga wojna światowa [The day before: Jews in Europe before the Second World War]. Warszawa: Wydawnictwo Magnum.

Zaremba, Marcin. 2001. Komunizm, legitymizacja, nacjonalizm: Nacjonalistyczna legitymizacja władzy komunistycznej w Polsce [Communism, legitimacy, nationalism: Nationalist legitimization of the communist authorities in Poland]. Warszawa: "Trio"; Instytut Studiów Politycznych Polskiej Akademii Nauk.

Zaremba, Marcin. 2012. Wielka trwoga: Polska 1944-1947 [Great fear: Poland 1944-1947]. Kraków: Znak,

Zarycki, Tomasz. 2016. "Polska jako peryferie stykowe" [Poland as a contact periphery]. In Polska jako peryferie, edited by Tomasz Zarycki, 105-47. Warszawa: Scholar. 


\section{INSIDER AND OUTSIDER EXPERIENCES}




\section{Daria Burnasheva}

ORCID 0000-0002-2029-6115

Arctic State Institute of Culture and Arts, Yakutsk

\section{UNCOVERING ARCTICNESS: EXPERIENCES OF ARCTIC IDENTITY AT HOME AND ABROAD*}

INTRODUCTION: WHY WRITE ABOUT PERSONAL EXPERIENCES?

My dissertation on Arctic identity began from a short presentation at the International Lomonosov Conference at Moscow State University in April 2014. Although I got the first prize in my session, the sociologists from the MSU Sociological Department claimed the topic of Arctic identity was not yet relevant, and probably would only become so in fifty years. As one can see from this example, despite growing interest in the Arctic, it still remains far from being fully understood by those who do not live in the region. Indeed, the character of Arctic research is still exclusive, relatively

* Parts of this paper are excerpts from an unpublished $\mathrm{PhD}$ dissertation defended in 2019 at the University of Warsaw. I used the quotes and made similar points derived from the dissertation in other papers in Anthropology and Archeology of Eurasia, Artic Yearbook and the volume Facing Challenges of Identification. The references are included where necessary. 
few researchers from outside the Arctic are actively engaged in Arctic Studies.

To set the stage, I first have to introduce myself by explaining my personal background. I am an Indigenous Sakha (Yakut). Brought up in a rural area, I learnt my native language at home and at school, where I was also introduced to my culture and traditions. As I believe, I have come to understand Arctic identity from an insider perspective. This perspective, coupled with training in Arctic Studies undertaken at universities both at home and abroad, allows me to capture Arctic identity and argue why it is important. However, in this short essay, I am not going to focus on Arctic identity itself, but will employ an alternative perspective and explore my own Arctic identity and the way it has been and is being formed.

As Michael Hall notes, in terms of research, what we do, we cannot ignore the personal, since personal subjectivities of our experiences are vital to our choice of research paths (Hall 2004). Doing research on identity, we inevitably face a need to define our own identity, which is not always easy. While these struggles are rarely manifested in dissertations, reflecting on personal experiences could provide a deeper understanding of these processes.

Personal experience is highly relevant in Indigenous research. As noted by Renee Linklater, an Aboriginal educator hailing from Rainy River First Nations, it "tells us that we have to locate ourselves in our study. That is, first write our own stories and share our position in the world before we write about the world. This is a big task, because first we have to come to terms with 
who we are and how we come to do the work that we do" (Linklater 2011, 1).

Locating myself in my research has indeed been one of the most challenging tasks that my PhD project posed for me. The two processes - formation of my own Arctic identity and my research project taking shape - went hand in hand throughout those years, mutually encouraging their development. It seems to me that the deeper I got involved in the issues of Arctic identity, the more I realized its importance for me personally. In this light, the process of formation of one's Arctic identity can be seen as becoming aware of being from the Arctic, or recognising one's Arcticness. I will try to uncover some specific attributes of this process below.

\section{EXPLAINING MY POSITION WITHIN MY RESEARCH}

In order to move forward with my goals, set up in the beginning of the essay, I should answer the questions about who I am and how I have come to do research on Arctic identity. In regard to my research, I position myself as an insider. Moreover, I identify myself as an Indigenous researcher. Though it might seem obvious, it is not easy to define who an Indigenous researcher is. In this section I shall try to answer this question, which will subsequently unfold my position in the research that I am doing.

The relation between academic research and Indigenous people is closely tied with the concept of colonialism (Tuhiwai 
Smith 1999; Porsanger 2004) and their coping with the "interest" paid by the outsider researchers to their physical characteristics and culture. A popular Sami joke about a typical Sami family consisting of parents, children, a dog and an anthropologist epitomizes the spirit with which the Sami people have learnt to cope with this situation (Mazzullo 1995, 23).

The Aboriginal Maori scholar Linda Tuhiwai Smith, author of the seminal critical work Decolonising Methodologies: Research and Indigenous Peoples, criticizes the entire Western concept of research and describes research's devastating effects on Indigenous peoples. The main idea of her work is that colonialism not only imposed control over Indigenous lands 62 and resources, but most importantly, dominated the mentality of Indigenous people and has continued to do so long after independence was gained and, therefore, its influence is far from being over (Tuhiwai Smith 1999).

However, the relation between academia and Indigenous scholars is even more complicated. Though there are a lot of scholars of Indigenous background, the academic environment still draws the line between scholarship and indigeneity. International conferences often claim to gather "scholars, experts and indigenous people," as though these categories were mutually exclusive. If Indigenous people who have been in the Arctic for centuries and even millennia cannot be considered as Arctic experts per se, who can be recognized as such? This categorisation seems profoundly wrong, since Indigenous belonging is not a category to be defined along with belonging to a professional domain (Burnasheva 2020b). Yet, as the 
Aboriginal scholar Michael Hart, a member of the Fisher River Cree Nation, described his situation, "the indigenous people were faced with leaving their indigeneity at the door when they entered the academic world" (Hart 2010, 1).

The position of Indigenous scholars remains indeterminate considering that the issues of Indigenous methodology were first raised comparatively recently. The problem is that Indigenous scholars themselves do not engage fully in the issues of Indigeneity or question their position in the research they do. Therefore, critique of the established Western approach to Indigenous research does not aim to abolish it but, first and foremost, to inspire Indigenous scholars to engage in alternative methodologies proposed by the Indigenous paradigmatic approach.

In their critical exploration of tourism and decolonial theory, Donna Chambers and Christine Buzinde, Black researchers of Caribbean and African descent, note that scholars of Indigenous background should recognize their engagement in "colonial thinking" manifest in their tendency to privilege theoretical approaches emanating from the Western academic thought and to insufficiently acknowledge the relevance - or even the legitimacy - of their own knowledges and cosmologies, which were represented as inferior to the Western system of knowledge (Chambers and Buzinde 2015, 5). This amounts to support and encouragement of long-established approach to Indigenous peoples as a problem or, at best, as societies with problems (Coates 2004, 16). As Tuhiwai Smith argues, the entire existence of Indigenous people 
seems to be a problem or a question for researchers: "problematising the indigenous is a Western obsession" (Tuhiwai Smith 1999, 91).

However, the trends are shifting in the realm of academia. A number of native researchers are actively working to ensure that Indigenous research is not only respectful, or "culturally sensitive," but is also based in approaches and processes that are parts of Indigenous cultures (Hart 2010, 1). Indigenous methodology has been developed by scholars of native ancestry, for example by Plains Cree / Saulteaux scholar Margaret Kovach, to legitimize the traditional way of collecting and transmitting knowledge. Aimed to overcome the domination of the Western paradigm in research, this methodology situates itself within the decolonising framework. However, it does not wish to suggest that Western perspectives have no value and should therefore be summarily dismissed. It is rather an acknowledgment by Indigenous researchers who have themselves privileged these perspectives and have consequently subordinated and even silenced their own knowledges, which in fact have equal legitimacy (Chambers and Buzinde 2015, 5).

As Indigenous Sami scholar Jelena Porsanger notes, neither does it mean that Indigenous people should be prioritized, but rather suggests that the Indigenous knowledge and expertise be taken into consideration. It allows to make visible what is special and needed, what is meaningful and logical in respect to our own understanding of ourselves and the world. The main aim is to ensure that research can be carried out in a more respectful, ethical, correct, sympathetic, useful and beneficial 
fashion as seen from the point of view of Indigenous peoples (Porsanger 2004, 107-108).

Therefore, the position of Indigenous researcher does not dismiss nor exclude the non-Indigenous one. In fact, the two perspectives can be combined and coexist. Morris et al. suggest that the insider and outsider perspectives are not necessarily opposed to each other and can be integrated to overcome limitations of narrower frameworks (Morris et al. 1999).

The ambiguous relationship between the two positions shows the liminal, in-between character of the Indigenous researcher. In this connection, Chambers and Buzinde note that Indigenous people have recognized the rather ambivalent and hybrid nature of their own identities not only in terms of social location and relationship with Western knowledge but also in terms of their own current geographical location within the Western institutions of power (Chambers and Buzinde $2015,11)$. This perspective is already instilled in the mentality and worldview of Indigenous peoples. Leroy Little Bear, a renowned Aboriginal scholar and veteran educator, member of the Blackfoot Confederacy, states that colonisation, instead of destroying the worldview among Aboriginal peoples, left a fragmentary, jagged worldview, neither Aboriginal, nor Eurocentric. In this regard, the Aboriginal consciousness became a site of overlapping, contentious, fragmented, competing desires and values: "It is this clash of worldviews that is at the heart of many current difficulties ... It is also this clash that suppresses diversity in choices and denies Aboriginal people harmony in their daily lives" (Little Bear 2000, 9). 
Here, the challenging task is to find the balance between two different paradigms. As noted by Fikret Berkes, distinguished Canadian scholar working on traditional ecological knowledge, instead of "synthetisizing" or "integrating" Indigenous knowledge into scientific knowledge, the question should be about "bridging of different kinds of knowledge respectfully" (Berkes 2018).

In this regard, the Indigenous scholar can be seen as located in a borderland, a liminal space in-between, where the Indigenous and Western worldviews and mentalities overlap, where identity is formed between different cultures, states, peoples, and traditions. I suggest that the liminal, in-between space that the Indigenous methodologies develop fosters an alternative way of thinking and knowing. As a result, it can provide deeper understanding of the colonial, post-colonial and de-colonial. It is first and foremost about decolonising ourselves and our mindset and mentality as Indigenous researchers, which is actually the aim of the Indigenous critique started by Linda Tuhiwai Smith (1999).

Finally, I should acknowledge my position of an Indigenous researcher as characterized above. Following Margaret Kovach, the already-mentioned Canadian scholar of Plains Cree / Saulteaux background, who brings to the foreground the conversational method as aligning with an Indigenous worldview that is based on orality as means of transmitting knowledge (Kovach 2010), I have decided to do so by writing about my personal experiences of Arctic identity.

Below, I therefore present the story of my Arctic identity formation, which was crucial to my personal and professional 
growth and understanding of my place in the world. I believe that it has been my life experience that has inspired and enabled me to embark on this journey and explore this research topic. I have decided to look at this process from two different yet coexisting perspectives: at home and abroad.

\section{ARCTIC IDENTITY AT HOME}

In 1994, I went to an elementary school and got a Finnishmade backpack as a present from the Yakutian government, which supported the population hit by economic difficulties of the early 1990s. These cold-resistant and extremely durable backpacks became an essential part of childhood memories for the 1990s generation of schoolchildren. In times when people were first introduced to imported goods, this referral to Finland was rather symbolic, considering the growing popularity in Sakha (Yakutia) of the Nordic and North American experience of sustainable development.

This time was marked by fundamental changes and transformations in the republic, which declared itself a sovereign unit within the Russian Federation (1990), elected its first president, Mikhail Nikolaev (1991) and passed the Constitution (1992). No doubt, the inspirational atmosphere of this period has greatly influenced my generation, mostly through school education. We had a chance to learn our native language, literature and culture at school as compulsory part of school curriculum. The day of signing the Declaration of State Sovereignty was celebrated annually as official bank holiday. 
The Arctic image of Yakutia was actively forming at that time, supported by the then President Mikhail Nikolaev, who was a key figure in the Arctic-related decision making. (Burnasheva 2020a). The notion of Arcticness was a good opportunity to underline the uniqueness and the advantages of the Northern community. Promoting Arctic identity drew on the support of local scholars (Stammler-Gossmann 2007), including the sociologist Ul'iana Vinokurova and her theory of the Arctic circumpolar civilization. She defines it as a community of people living in similar climatic natural conditions of the circumpolar North and being united by a close culture, both spiritual and material, and worldview (Vinokurova 2011; Vinokurova and Iakovets 2016).

Political geographers note that building of a region is not a mere political choice, but it is always historically and culturally rooted: a region is not created ex nihilo (Neumann 1992, 1999 as cited in Keskitalo 2004; Paasi 1986). On the one hand, from within, the Arctic identity in Sakha (Yakutia) was predetermined by historical and cultural traits specific to the North. On the other, from without, it was stimulated by growing global interest in the Arctic (Burnasheva 2020b).

By the end of the 1980s, the world had witnessed a remarkable growth of environmental awareness, strongly related to a rise of Indigenous - and in a wider context, human - rights. The involvement of Arctic states in Arctic issues and their desire to find common solutions to existing problems was inspired by the then Soviet Premier Mikhail Gorbachev in his Murmansk speech of 1987, which promoted greater cooperation among 
Arctic countries and the region as a zone of peace (Steinberg, Tasch and Gerhardt 2015).

For the Indigenous peoples of Sakha (Yakutia), this was a period marked by a significant growth of their self-determination and identity, and restoration of self-dignity. One of the significant steps towards the global Arctic community taken by Sakha (Yakutia) was the development of an extensive environmental policy. In doing so, Sakha (Yakutia) tried to overcome its colonial-like status of raw materials source imposed on it by the federal center (Burnasheva 2019; Burnasheva 2020b). Never in its history had the republican government taken the environmental concerns so seriously.

The Arctic identity of Sakha (Yakutia) was also a demonstration of its willingness to become, despite its regional character, an independent player in the international arena. Since the end of the 1980s, it became actively engaged in the activities of such international organisations as the Arctic Council and the Northern Forum, being a founding member of the latter. Symbolically, in 1989, the Alaskan city of Fairbanks became the first sister-city to Yakutsk, capital of the republic (Burnasheva 2019; Burnasheva 2020a).

Subsequently, in 1996, the Yakutsk State University became a founding member of the international network of educational and research institutions in the North, called the "university without walls," the University of the Arctic, or the UArctic. Within its framework, intensive international cooperation began in the area of research and education. The online Circumpolar Studies program was co-created by its member institutions. 
Offered online by partner universities, it allowed students from even the most remote locations to integrate into an international Arctic community.

As an English Philology student, I took online Circumpolar Studies courses, where I studied in online classrooms with youth from all over the Arctic. The courses included Peoples and Cultures, Land and Environment, and Contemporary Issues of the Circumpolar North at the University of Alaska Fairbanks (US) as well as Yukon College, University of Manitoba, Saint Mary's University, University of Saskatchewan and University of Northern British Columbia (Canada). We often had assignments to describe a case or apply theoretical knowledge to a certain situation at our home countries and regions, so we shared a lot of local knowledge and experience with one another, expanding our horizons with knowledge of other Arctic regions.

Though we certainly had no awaraness of a shared Arctic identity, it was clear that as young people, we shared a lot in common, often struggling with the same issues specific to the Arctic, such as isolation, hard accessibility, non-availability of certain things, etc. These courses allowed me to further develop my interest in the Arctic and choose Arctic-related topics for my diploma projects: first, on the linguistic aspect of advertising campaigns of Arctic universities and second, on the representation of the North in ethnographic films.

In 2011, after graduating from the universities in Yakutsk and Versailles, I chose Tiksi, a small Arctic town of about 5,000 residents, as the place for my first employment as a school teacher. Tiksi was built to serve the Northern Sea Route as part 
of Soviet osvoenie Severa, or conquest of the North, one of the most ambitious and large-scale urbanisation projects humanity has ever implemented. The project was aimed at fundamentally transforming the vast territories lying between the Barents and Bering Seas and covering the northern edge of almost the entire Eurasian Continent. This process not only created urban spaces, never before seen in the Northern environment, but also produced new meanings, symbols and perceptions. It was in this Far Northern region that, as I believe, I understood a number of important factors forming Arctic identity, such as its strong potential as a regional factor and the sense of belonging among the non-Indigenous settler communities for whom the Arctic is also home.

In 2012, I took an international coordinator job at my home university, where I mainly worked with the projects and programs related to the cooperation within the UArctic network. At meetings in and outside Russia, I met colleagues from the Arctic region. It was an important part of my professional experience to foster and promote the ideas of building a sustainable future for our Arctic region by means of cooperation in the academic field. I had some very interesting conversations regarding the role of academic mobility and its opportunities for building an Arctic identity among the youth. During my work in the international relations field, I have come to understand the importance of dialogue and intercultural communication in the formation of common identity. 


\section{ARCTIC IDENTITY ABROAD}

First and foremost, I feel grateful for the opportunities that enabled me, a person from a Yakutian rural area, to travel and study abroad, expanding my horizons and shaping my mindset. In this regard, I am in a way a typical product of international cooperation in the Arctic, a part of an entire generation of young Russians educated in Nordic countries through cooperation programs, as described by the Norwegian scholar Geir Hønneland (Hønneland 2016, 127-28).

In 2007, I took part in a UArctic north2north exchange program and spent one semester in Northern Norway, where I was first exposed to international educational environment and Norwegian lifestyle. This experience has strongly influenced my perspective on the world. In my exchange feedback I wrote that it "has made me feel as a part of one big community, one environment, one mentality, one Arctic. I wish that everyone living in the North could feel the same" (Burnasheva 2008, 29).

Ten years later, this statement is still highly relevant for me. The term "identity" was not on my mind yet back then, but I apparently tried to reflect on the shared sense of community in the Arctic. In general, three important milestones have encouraged the formation of my Arctic identity: studies at the University of Tromsø, University of Versailles Saint-Quentinen-Yvelines and University of Warsaw.

The Arctic University of Norway in Tromsø is the northernmost university in the world. In 2009, I went there on exchange and took the courses at its Department of Social Anthropology 
focused on Indigenous Studies, which gave me insight into contemporary Indigenous issues in a wider global context. We studied with Indigenous people from all over the world: I got to meet fellow Aboriginal people from Canada, the US, the Nordic countries and Russia. Trips to traditional Sami areas in Manndalen gave us knowledge of Indigenous issues in Northern Norway, providing at the same time an interesting insight to the global character of Indigeneity.

In 2010, after graduating from my home university, I had a chance to take the Master's Program in Arctic Studies at the University of Versailles Saint-Quentin-en-Yvelines in France. Although a non-Arctic state, France obtained the observer status at the Arctic Council in 2000. The Arctic Studies in France have been strongly influenced by the legacy of renowned French cultural anthropologist and polar researcher Jean Malaurie, an active advocate of Indigenous peoples' rights and peaceful cooperation in the Arctic. His special interest in Greenland is instilled in the tradition of French Arctic research, which now carries on his heritage. In line with this tradition, the program was mostly focused on Greenland; it did, however, provide us with deeper knowledge of Arctic issues. Our educational trip to Copenhagen gave us a comprehension of the Greenlandic case in the context of power relations and post-colonialism.

It is during these stays abroad that I came to understand the common identity shared by the people of the Arctic. In 2014, I started my PhD studies in Poland, which turned out to be an entirely new experience compared to my previous stays in Norway and France. 


\section{SOME REFLECTIONS ON MY PHD PROJECT}

Seven years ago, I started my $\mathrm{PhD}$ journey at the University of Warsaw and stepped into the labyrinthine territory called "Searching for Identity." As the title of our PhD program suggests, the formation of identities is a complex process, in which both the global and local aspects play a crucial role. The Arctic does indeed prove to be a demonstrative example of global and local implications of identity, along with issues of civilizations and borderlands that we touched upon in our program.

At the first glance, the Faculty of "Artes Liberales" of the University of Warsaw seems far from the Arctic, both literally and figuratively. I struggled to find a way to apply my Arctic topic to the existing Siberian framework and it was not very successful. Unlike Siberia, the Arctic embodies global and international dimensions and far exceeds the boundaries and limitations set by the Siberian context. However, I eventually came to understand the 114 applicability of the Arctic to the Mediterranean context, which naturally fit the Faculty's focus on this region.

In a famous 1921 account titled The Friendly Arctic: The Story of Five Years in the Polar Regions, the IcelandicCanadian ethnographer and polar explorer Vilhjalmur Stefansson predicted that the Arctic would soon become a region of great strategic importance. Located between continents, as the Mediterranean between Europe and Africa, the Arctic, Stefansson claimed, would one day become a Polar 
Mediterranean (Stefansson 1921). His prediction was certainly premature then, and at a time when the colonial perspective prevailed in Arctic perceptions, his ideas were much criticized, casting shadow on his position as an Arctic expert and visionary (Gaupseth 2012).

However, the recently documented losses in sea ice suggest that the transformation is finally taking place, a century after it was predicted (Dodds 2010). In this connection, the Faculty of "Artes Liberales" turned out to be the right place to explore and deepen my understanding of the concepts of civilization, borderland and identity in relation to the "Polar Mediterranean," a region with cold climate, but hot geopolitics.

The Arctic is rapidly changing and globalising. In the face of abrupt climate change that will certainly affect the whole planet and pose challenges for its future, states outside the Arctic are developing their Arctic policies. Thus, the Arctic issues are not limited to local, regional and national scales, but present interest to the whole world. Poland also has its Arctic policy, adopted by the Ministry of Foreign Affairs in 2015.

Regarding the Polish tradition of Arctic research, I would suggest that it began even prior to the establishment of a polar station on Spitsbergen in 1957. Though not yet recognized as Arctic in the 19th and early 20th centuries, the North became the center of attention for the Polish political exiles turned ethnographers, such as Wacław Sieroszewski. Having spent twelve years in Sakha (Yakutia), he came to be the advocate of understanding civilization as a culture, not a level of technological development. In this regard, he acknowledged the 
importance of the traditional knowledge system and cosmology, which allowed him not only to survive in severe conditions of the North, but most importantly, to rediscover himself as a part of this system (Seroshevskii 1997; Takasaeva 2017).

For Indigenous scholars, addressing those researchers who attempted to challenge the established colonial paradigm, and the corresponding ways of describing the native people, represents a particular mission. It is very symbolic that we, the Indigenous researchers ourselves, should re-introduce them to modern academia, since their ideas anticipated the development of alternative methodological approaches which support the Indigenous paradigm.

All in all, the time spent at the University of Warsaw proved to be both challenging and instructive. I never realized how far it would take me when as a Sociology student at the North-Easter Federal University, I wrote to Professor Ul'iana Vinokurova and asked if it was possible for her to become my research advisor.

\section{CONCLUSION: ARCTICNESS UNCOVERED?}

As the Arctic is rapidly transforming, new Arctic-related concepts are being coined and used on an everyday basis. One of them, Arcticness, as noted by editor of a book of the same title, is aimed to reflect the quality of "being Arctic" (Kelman 2017, 1-6). It is not easy to define the Arctic, since it involves various topics, contexts and even interests, so determining its qualities likewise poses a challenge (Medby 2017). However, as noted by Hall and Tucker, just because something is difficult to 
describe does not mean it is not there or that it is unimportant (Hall and Tucker 2004, 1).

The humanities, social and natural sciences define the Arctic in their own ways depending on their research focus. The Arctic does not have clear borders, but rather boundaries which fluctuate and are subject to various interpretations by those who are involved in Arctic issues, be it in terms of research or policy. With no borders or universal definition, the Arctic becomes what states and actors make of it. At its heart, Arcticness is an issue of identity, power and interestformation (Duda 2017, 47), in other words, as put by Nikolas Sellheim, "Arcticness lies in the eye of the beholder" (Sellheim 2017, 112).

As a borderland civilization between the North American, Western European and Eurasian civilizations (Vinokurova 2011; Vinokurova and Iakovets 2016), the Arctic also provides an opportunity to think and act beyond the borders. Similarly, Arcticness has a significant potential for overcoming the limits of locality. For academia, this means overcoming the colonial paradigm that often supports the backwardness, isolation and frontier narratives. Arcticness provides an everyday context and basis for social identity, cultural survival and spiritual life. In a wider context, it denotes a system of knowledge that constitutes a specific type of civilization based on the principles of sustainability and resilience.

Reflecting on Arcticness, Ilan Kelman notes that "it is about taking the power and creating the voice in, for and of the Arctic which for too long has resided outside the northern latitudes - 
to a large extent revealing an 'Arctic of the oppressed.' It is about creating an Arctic home for those living in this everchanging home" (Kelman 2017, 153). Being an Indigenous person in academia, one cannot escape the feeling of being objectified and your homeland being associated solely with a resource frontier. However, it is up to ourselves and our own determination to recognize those patterns and try to overcome them.

While working at my home university, I came across situations that clearly demonstrated an urgent need to change our mindset. One example were university promotional brochures, now out of use, that proudly presented Sakha (Yakutia) in frontier terms as a place where diamonds, gold and oil were extracted. Instead of focusing on the intellectual potential, ethnic and cultural diversity and creative atmosphere, it employed colonial-like representations, which, according to Tuhiwai Smith, demonstrated the state of our mentality (Tuhiwai Smith 1999). In this connection, Arcticness challenges the colonial patterns that dominate the mentality of Indigenous people and distort their self-image and identity.

My $\mathrm{PhD}$ thesis did not intend to give full and ultimate definitions of what the Arctic, Arcticness and Arctic identity were. All these concepts represent a process, not a result, therefore, as noted by Ingrid Medby, they remain open to discussion and interpretation by those to whom they are relevant (Medby 2017), across state borders and on the global, national, and local levels. Thus, the Arctic and Arcticness represent a unique variety of glocality - quality of being global and local at the same time. 
The Arctic is undergoing profound change, and so is the concept of Arcticness. However, the most important aspect of Arcticness is that it always refers to humans and their experiences.

\section{REFERENCES}

Berkes, Fikret. 2018. Keynote speech at the IPBES Seminar on Arctic Indigenous and Local Knowledge and Sustainability, June 8, Helsinki, Finland.

Burnasheva, Daria. 2008. "Student Profile." In Shared Voices: The University of the Arctic Newsletter: International Polar Year Legacy Edition, edited by Outi Snellman, 29. Rovaniemi: University of the Arctic.

Burnasheva, Daria. 2019. "Arctic Identity: Between Frontier and Homeland." Anthropology \& Archeology of Eurasia 58 (4): 271-307.

Burnasheva, Daria. 2020a. "Searching for a New Identity in a New Era: Emergence and Development of Sakha (Yakutia) as an Arctic Region." In Facing Challenges of Identification: Investigating Identities of Buryats and Their Neighbor Peoples, edited by Kamil M. Wielecki and Ivan Peshkov, 227-55. Warsaw: University of Warsaw.

Burnasheva, Daria. 2020b. "Understanding Climate Change from an Indigenous Paradigm: Identity, Spirituality and Hydrosocial Relations in the Arctic." Arctic Yearbook 2020: 1-17.

Chambers, Donna, and Christine Buzinde. 2015. "Tourism and Decolonisation: Locating Research and Self." Annals of Tourism Research 51: 1-16.

Coates, S. Ken. 2004. A Global History of Indigenous Peoples: Struggle and Survival. New York: Palgrave Macmillan.

Dodds, Klaus. 2010. “A Polar Mediterranean? Accessibility, Resources and Sovereignty in the Arctic Ocean." Global Policy 1 (3): 303-11.

Duda, Elizabeth. 2017. "Arcticness: In the Making of the Beholder." In Arcticness: Power and Voice from the North, edited by Ilan Kelman, 40-51. London: UCL Press.

Gaupseth, Silje. 2012. "A Hero in the Friendly Arctic: Deconstructing Vilhjalmur Stefansson's Rhetorical Maneuver.” Nordlit 29: 69-78.

Hall, Michael C. 2004. "Reflexivity and Tourism Research: Situating Myself and/ with Others." In Qualitative Research in Tourism: Ontologies, Epistemologies and Methodologies, edited by Jenny Phillimore and Lisa Goodson, 137-53. London: Routledge.

Hall, Michael C., and Hazel Tucker. 2004. Tourism and Postcolonialism: Contested Discourses, Identities and Representations. London: Routledge.

Hart, Michael A. 2010. "Indigenous Worldviews, Knowledge, and Research: The Development of an Indigenous Research Paradigm.” Journal of Indigenous Voices in the Social Work 1 (1): 1-16. 


\section{Daria Burnasheva}

Hønneland, Geir. 1995. "Northerners: Common Identity or Worlds Apart?" In The East-West Interface in the European North, edited by Margareta Dahlström, Heikki Eskelinen, and Ulf Wiberg, 29-44. Stockholm: Nordisk samhällsgeografisk tidskrift.

Hønneland, Geir. 2016. Russia and the Arctic: Environment, Identity and Foreign Policy. London: IB Tauris.

Kelman, Ilan. 2017. Arcticness: Power and Voice from the North. London: UCL Press.

Keskitalo, E. Carina H. 2004. Negotiating the Arctic: The Construction of an International Region. New York: Routledge.

Kovach, Margaret. 2010. "Conversational Method in Indigenous Research." First Peoples Child \& Family Review 5 (1): 40-48.

Linklater, Renee L.B.L. 2011. Decolonising Trauma Work: Indigenous Practitioners Share Stories and Strategies (PhD thesis). Toronto: University of Toronto.

Little Bear, Leroy. 2000. “Jagged Worldviews Collide.” In Reclaiming Indigenous Voice and Vision, edited by Marie Battiste, 77-85. Vancouver: UBC Press.

Mazzullo, Nuccio. 1995. Perception, Tradition and Environment among Sami People in Northeastern Finland (PhD thesis). Manchaster: University of Manchester.

Medby, Ingrid. 2017. "Preface: Arcticness and Change." In Arcticness: Power and Voice from the North, edited by Ilan Kelman, V-VII. London: UCL Press.

Morris, Michael W. et al. 1999. "Views from Inside and Outside: Integrating Emic and Etic Insights about Culture and Justice Judgement." Academy of Management Review 24 (4): 781-96.

Neumann, Iver. 1992. "From a Nordic Region to What?" In The Baltic Sea Area: A Region in the Making, edited by Sverre Jervell, Mare Kukk, and Petti Joenniemi, 62-76. Karlskrona: The Baltic Institute.

Neumann, Iver. 1999. Uses of the Other: The East in European Identity Formation. Manchester: Manchester University Press.

Paasi, Anssi. 1986. "The Institutionalisation of Regions: A Theoretical Framework for Understanding the Emergence of Regions and the Constitution of Regional Identity." Fennia 164 (1): 105-46.

Porsanger, Jelena. 2004. "An Essay about Indigenous Methodology." Nordlit 15: 105-20.

Sellheim, Nikolas. 2017. "Scopes and limits of 'Arcticness': Arctic Livelihoods, Marine Mammals and the Law." In Arcticness: Power and Voice from the North, edited by Ilan Kelman, 102-15. London: UCL Press.

Seroshevskii, Vatslav [Wacław Sieroszewski]. 1997. Iakutskie rasskazy [Yakutian stories]. Yakutsk: Kuduk.

Stammler-Gossmann, Anna. 2007. "Reshaping the North of Russia: Towards a Conception of Space.” Arctic \& Antarctic: International Journal of Circumpolar Sociocultural Issues 1 (1): 53-97.

Steinberg, Peter E., Jeremy Tasch and Hannes Gerhardt. 2015. Contesting the Arctic: Politics and Imaginaries in the Circumpolar North. New York: Palgrave.

Stefansson, Vilhjalmur. 1921. The Friendly Arctic: The Story of Five Years in Polar Regions. New York: The Macmillan Company. 
Takasaeva, Kunney. 2017. Jakuckie prace Wacława Sieroszewskiego w kontekście przemian świadomości narodowej Sacha (Jakutów) [The Yakut works of Wacław Sieroszewski in the context of changes in Sakha (Yakut) national consciousness] (PhD thesis). Warszawa: Uniwersytet Warszawski.

Tuhiwai Smith, Linda. 1999. Decolonizing Methodologies: Research and Indigenous Peoples. Dunedin: University of Otago Press.

Vinokurova, Ul'iana A. 2011. Tsirkumpoliarnaia tsivilizatsiia: Idei i proekty [The circumpolar civilization: Ideas and projects]. Yakutsk: AGIIK.

Vinokurova, Ul'iana A., and Iurii Iakovets. 2016. Arkticheskaia tsirkumpoliarnaia tsivilizatsiia [The Arctic circumpolar civilization]. Novosibirsk: Nauka. 


\section{Galina Dondukova}

ORCID 0000-0002-4390-7556

East Siberia State University of Technology and Management, Ulan-Ude

\section{INSIDER, OUTSIDER, \\ OR IN-BETWEEN? THE EXPERIENCE \\ OF STUDYING THE BURYAT ETHNIC \\ IDENTITY IN POLAND*}

In May 2018, I attended the conference "Mapping Cultural

Identities: Translations and Intersections" in Bucharest, Romania. When I was discussing the topic of my dissertation during a coffee break, one of the scholars pointed out that my research did not imply fieldwork, but rather homework. I had never encountered such wordplay before, though I was conscious of being an insider researcher. So when a call for papers for this collection was announced, I decided to write an essay in which I would reflect on my insider experience using my doctoral research as a case study.

As contemporary scholarship argues, both insider and outsider approaches have their advantages and disadvantages (see Young 2004; Chavez 2008; Greene 2014). What is more, a recent critique proposes that

* This article is a revised version of Introduction to my $\mathrm{PhD}$ dissertation The Settled Sorrow of Saddle: The Buryat Ethnic Identity in the Poetry of Bair Dugarov (Dondukova 2019). 
instead of worrying over whether one is too much of an insider or outsider, researchers should strive to be both. There is much to be gained from being close to one's research, as there is much to be gained from keeping one's distance and having an outside perspective (Greene 2014, 10).

In this essay, I argue that in the contemporary scholarship the researcher's identity becomes more complicated than a binary division into insiders and outsiders. Using my own example, I aim to show a researcher in-between. First of all, even though I am an insider, ethnically Buryat, I am "alienated” from the "field," as I perform my research in Poland, and thus have an opportunity to distance myself from the Buryat community in order to attain a broader view. In other words, I neither fully belong among local Buryat scholars, nor can I be defined as a Western scholar. Another layer of my mixed researcher's identity emerged due to the state of the Buryat culture and my relations with it. During my academic activities, I realized how much knowledge about history and culture of Buryats I actually lacked, so I felt myself an outsider to the community under research. And performing homework helped me to enrich my own Buryat ethnic identity.

I start with introducing the historical background of Buryatia and the story of its Soviet modernization, which resulted in mass acculturation and forgetting of the "traditional" culture among the Buryats. I reflect on the influence of Polish academia on my insider identity, and analyze the choice of the topic for my dissertation and the way I conducted my research on Bair Dugarov's poetry from the point of view of my insiderness. I conclude by demonstrating how my research enhanced my Buryat identity. 


\section{AN INSIDER NOT "KNOWING" THE FIELD}

The majority of the articles devoted to insider research focuses mainly on the advantages and disadvantages of insiders and outsiders, or what the special training for each of them should be. Christina Chavez writes,

I entered the field with my training as a traditional scholar, some readings on insider issues, and little critical reflection or understanding of my unique circumstance. After the completion of the project, I had experienced my status at times advantageous, at other times, not. More importantly, I realized that neither my insiderness, nor my training, adequately prepared me to maximize the privilege of already "knowing" the field ... (Chavez 2008, 480).

From this perspective, I actually started my research not "knowing" the field. I can say that even before I began my $\mathrm{PhD}$ studies, I lacked the cultural and even linguistic background of a Buryat, and what is more, I was not the only Buryat with such gaps in knowledge about Buryat history and culture. In order to better understand the reasons for such state of affairs, it is necessary to introduce the historical context of Buryatia. ${ }^{1}$

The Buryat people are an ethnic group living on the shores of Lake Baikal. The Buryats represent the major northern subgroup of the Mongolian peoples and are one of the largest ethnic groups of Siberia. Before entering the Russian Empire in the late 17 th and early 18 th centuries, they were firmly integrated into a broader Mongolian culture. Many centuries of

\footnotetext{
${ }^{1}$ When speaking about Buryatia, I refer to ethnic Buryatia, a region in Southeastern Siberia, which includes the Republic of Buryatia and parts of Irkutsk Oblast and Zabaikalskii Krai (see Nowicka 2015).
} 
living on a common territory, of similar cultural and religious practices, shared pastoralism, as well as the single literary language provided relative unity to the Mongolian world and its historical and literary traditions. The literary heritage of the Buryats included oral and written literary monuments, historical chronicles and, crucially, didactic Buddhist literature. The Soviet period brought rapid advancements in social mobility, education levels and urbanization, but at the same time was marked by an attempt to discredit the past of the Buryats. Following the policy of that time, the Soviet scholars were presenting the rapid modernization as a transition from the backward past to the advanced present and future. The ambition to create a new "Soviet man," who would be free of any ethnic background, resulted in several decades of acculturation, most dramatically endured by non-Russian ethnic groups, including the Buryats. Beginning from the 1950s and ' $60 \mathrm{~s}$, the languages of other nationalities were gradually replaced by Russian in the spheres of politics, culture and education, since the state language and new social models were considered to be the only possible way to general progress. As a result, the Buryat language was taught neither in higher education institutions nor in technical schools. In the beginning of the 1970s, education in Buryat language was prohibited even at primary schools. Such policy could not but produce identity confusion and transformation for people. Only after 1986 did the study of the Buryat language become accepted at schools where most of pupils were Buryats. Some measures were also taken to foster the language, including an increase in publishing literature 
in Buryat and broadcasting programs on radio and television in the language.

After the fall of the USSR, ethnic identification was placed at the center of the social and political discourse in Buryatia. However, the national and cultural revival movement involved mostly politicians, the academic community, and cultural workers. The majority of the Buryat population, while defining themselves as ethnic Buryats, actually knew very little about Buryat culture and seldom spoke Buryat in everyday life. The trend to consider the language as an irrelevant ethnocultural identity marker became so strong that it started to receive a more symbolic, unifying value and not speaking Buryat did not affect negatively the ethnic identity itself (see Khilkhanova and Khilkhanov 2004, 22). I realized this based on my own experience. Though I had studied the Buryat language for eight years at school, and another year at the university, I could not use it in everyday interaction with relatives, or write or read in Buryat without using a dictionary. My mother, despite speaking very good Buryat herself, made little effort to communicate in Buryat at home with me or my sister, and we did not actually feel any strong obligation to learn the language. Nevertheless, I always considered myself a Buryat. The same vacuum characterized my, and many other Buryats', knowledge of Buryat history or culture. In such a way, many elements of traditional culture were forgotten.

Buryats of my generation did not study Buryat history at school. At universities we also had only the general Russian history courses, with a few lectures on the history of Buryatia, 


\section{Galina Dondukova}

where most attention was given to the period since Russian Cossacks settled in Transbaikalia in the 17th century. In other words, by the beginning of the 21 st century, for the majority of Buryats the proclamation of their Buryatness had little to do with the essential knowledge about the language, history, or culture of Buryats. Due to historical developments, most notably the years of Soviet acculturation, I, as well as many of other Buryats, could not speak the Buryat language and shared general ignorance about the history and culture of my native people.

\section{AN INSIDER RESEARCHER IN POLAND}

Before entering the PhD program "Searching for Identity: Global Challenges, Local Traditions" at the Faculty of "Artes Liberales," University of Warsaw, my major was Linguistics. I had obtained the degree of kandidat nauk (Candidate of Sciences, equivalent to a doctoral degree) with a dissertation devoted to the translator's commentary in the cognitive theory of translation. Due to the general topic of the $\mathrm{PhD}$ program in Poland, I had to shift from my initial academic interests and start a completely new research project. I did not have any specific knowledge of qualitative research within anthropological or ethnographic studies and knew few trends in contemporary literary studies. In other words, I was a total beginner in those fields of the human sciences, and could feel a definite gap between my level of training and that of other, Western scholars. Communicating with Polish anthropologists who had studied 
various aspects of Buryat culture, I also soon understood that I actually knew less than them about my own culture.

I had to admit that the widespread idea that insiders a priori "possess a more profound knowledge of the historical and practical happenings of the field" (Chavez 2008, 481) was actually a false one. I started to fill in the gaps about Buryat history and literature and even included in my dissertation chapters about the development of Buryat literature since the 13th century and about the post-Soviet ethnic identity revival. I realized that performing research in Poland made me feel more inside the Buryat community than I had ever felt in Buryatia. In other words, a study on ethnic identity of Buryats enhanced my insiderness, my own ethnic identity.

One of the complications of insider positionality that I faced was the "difficulty with recognizing patterns due to familiarity with community" (Chavez 2008, 479). To overcome this issue, my supervisor, Ewa Lukaszyk, advised me to always write with the readers in mind. Indeed, this problem is partially linked with the switch in the expected readers. Instead of a Buryat audience to which a local scholar addresses his or her work, I was now writing a dissertation in English, for English-speaking readers, who, due to the lack of research devoted to Buryat literature available in the English language, would demand the broadest possible historical and cultural context of Buryatia. What a Buryat would understand without any explanations, an outsider reader would define as new and unknown: how to celebrate the Sagaalgan, who was Geser, or what does sülde mean? The Buryat concepts connected to traditional culture, 
toponyms, and simply words in the Buryat language now required clarification. I have already mentioned that by doing research, I actually enriched my own ethnic identity because I had not had profound knowledge of the history of Buryatia before I started my doctoral studies. But at the same time recognizing the possible gaps in the readers' familiarity with Buryat culture and looking into the origin and history of various terms somehow made me distance myself from my insider status and, thus, helped me in "recognizing the patterns."

What is more, the PhD studies developed my critical thinking towards the issues of identity construction. I reconsidered a lot of facts of Buryat history and realized that many of them could be 90 seen as "invented." Once, during the summer break after the first year of studies, my parents took me to mineral springs located not far from Ulan-Ude. All the way there I was admiring the beauty of our native land. At one moment, the steppe landscape changed to rocky mountains, and my mother said in instructive tone that a new settlement which had belonged to Genghis Khan had been discovered not far from that place. I already knew about long-lasting debates concerning Genghis Khan's origin and Buryat efforts to inscribe the ancestry of Buryat territories into the all-Mongolian history (see Amogolonova, Elaeva, and Skrynnikova 2005), so I smiled and said it all sounded doubtful to me. Mother got really angry and murmured something about me having become too smart. I could understand her reaction, because to her it was an indisputable fact. I can imagine how the local media presented that story of Genghis Khan settlement's discovery with much argumentation, arrival 
of respectful scientists (preferably from abroad), evidence from some historical chronicles about this place, and other similar references. No wonder the Buryat community starts to accept this information and include it in their mental map of Buryatia and its history. My studies abroad not only helped me to enrich my knowledge about Buryatia and the Buryats, but also helped me to attain a broader view of various historical facts, dig deeper into the roots of various events and find out the reasons hidden between the lines of common facts. In other words, even though an insider, owing to my studies abroad, I developed some characteristics of an outsider. I learned to separate myself from the "field" so that my familiarity with the Buryat community did not confuse me in recognizing the patterns.

\section{CHOOSING THE TOPIC FOR THE PHD DISSERTATION}

For a June 2014 doctoral workshop, Professor Tatiana Bernyukevich proposed the topic of constructed identity, and the first idea that came to my mind was to write about the poem The Nomad's Star by Bair Dugarov. Adapted to music, this poem and song were very popular during the time of post-Soviet searching for ethnic identity and ideally fit the nomadic nostalgia of the people at that time. In my presentation, I argued that the poet actively promoted the nomadic identity of the Buryats, evoking such images as the rider, the horse, the yurt, etc. But my acquaintance with Dugarov's poetry happened much earlier, in 2008, when I was still an undergraduate student. My aunt 


\section{Galina Dondukova}

presented to me a collection of Dugarov's poems entitled The String of Earth and Sky (Dugarov 2007). Frankly speaking, I was quite skeptical about Buryat literature, I did not expect the locals to write anything comparable to Russian poetry. To my surprise, Dugarov's poetry impressed me a lot, as if I was learning the history of the Buryats in an artistic form. The Nomad's Star opened the collection, and this fact determined its major place not only in that book but, probably, in all of the author's work (the collection was devoted to the 60th anniversary of the poet). I knew that Dugarov (born 1947) was one of the most popular poets of contemporary Buryatia. His poems were recognizable and were ranked as modern classics of Buryat literature.

After that workshop, I no longer had any more doubts about the topic of my future thesis: I wanted to write about the reflection of Buryat ethnic identity in the poetry of Bair Dugarov. Hence, my personal insider experience prompted me to choose the subject for analysis. As I discovered later, Dugarov, both his poetry and his activities as the head of the Union of Writers of Buryatia in the 1990s, indeed had a great impact on the postSoviet national and cultural revival movement. Such "natural" decision about the topic of dissertation could not be made by an outsider. It would demand his or her long inclusion into the field: he or she would have to identify the most important cultural activists in Buryatia as well as study the public opinion about them. 


\section{ACCESS AND ESTABLISHING INTERACTION WITH BAIR DUGAROV}

An inestimable advantage of doing research about a living classic is that one can get acquainted with the poet himself, ask about his own vision of the poems and learn the story of their appearance from his own words. This gives a unique opportunity to follow very closely the development of his poetry, its style, and genres. What is more, the interviews with the poet seen as field data can represent a valuable historical material for the future generations. I must admit that, once again, being Buryat proved an advantage for me from the point of view of securing access to the "field" and making contacts. Getting acquainted with the poet became possible thanks to the local bonds and relations. In 2014, a friend of my parents' accidentally met Bair Dugarov at Altargana Festival ${ }^{2}$ and told him that there was a Buryat girl who wanted to write a PhD thesis about him. Dugarov was very intrigued and gave his business card to the woman. I called him and that is how I got access to the poet.

At the very first meeting, we had a long talk at his office at the Institute of Mongolian, Buddhist and Tibetan Studies of the Russian Academy of Sciences and managed to establish "natural" interaction very quickly. I think this was another advantage of being an insider - we eliminated the necessity for official talks or reading his poems out loud. Following that

${ }^{2}$ The Altargana International Festival aims to preserve, protect and promote the culture and customs of people of Buryat ethnic origin. It has been organized biennially since 1994. On July 18-21, 2014, it was held in Dadal Sum, Khentii Aimag, Mongolia. The name Altargana originates from the name of the plant altan khargana, or goldenrod, which symbolizes eternity. 
first occasion in 2014 we started to meet almost every half a year, each time I was in Ulan-Ude. We talked about our news, discussed our academic achievements, and of course, my $\mathrm{PhD}$ project. Almost every time we met, Bair Dugarov presented me with a book or two - his collections of poems or works of Buryat scholars devoted to his poetry. He usually signed his books for me. On one of the collections, he wrote:

\section{To Galina Dondukova - my nice countrywoman - Uragshaa! Warmly from the author}

The poet underlined our common belonging in the Buryat land, that is, recognized me as an insider. As for the Buryat word uragshaa, it means "onwards" and is a very popular Buryat slogan today, which originally served as an all-Mongolian battle-cry. In this context, I see it as an encouragement for my academic progress and my finishing of the $\mathrm{PhD}$ thesis. Buryat society has always placed a great value on education, and statistics of the late Soviet period proved that educational and professional levels of the Buryats were one of the highest throughout the Soviet Union. ${ }^{3}$ That is why I think Dugarov was not only proud about his poetry being studied, but also appreciated a Buryat girl, his countrywoman, making progress in Western academia.

Nevertheless, the insider status also had a side effect for me, one associated with reciprocity. In 2017, Bair Dugarov told

${ }^{3}$ As Melissa Chakars notes, "education became increasingly an ideal for many Buryat families who came to expect that their children needed an education for success" (Chakars 2014, 120). 
me he would like to publish a book in English, and offered me to make translation of his poems from Russian into English. Perceiving this as an ethical act of reciprocation, I could not refuse his offer. So I started to work on selecting the poems and making word-for-word translations. He also gave me the materials for the new collection he already had - translations of about 30 poems which were made by his American friend in the 1990s. I needed to sort them out and to digitize and revise all the materials for the collection. One might argue that this additional work made me take more time to complete my research. Thus, while my insider status benefited me as I was entering "the field," it now obligated me to do additional reciprocal work, which most likely would not be experienced by an outsider scholar, whose research - and the help provided therein - would not be perceived by the poet as an endeavor aimed at promoting his and the researcher's common culture.

\section{MORE BURYAT THAN EVER BEFORE}

In my dissertation (Dondukova 2019), after introducing the historical background of Buryatia, its literary tradition as well as identity revival in the post-Soviet period, I undertake the analysis of the poems by Bair Dugarov which constitutes the practical part of my thesis. Close reading Dugarov's poems made me go deeper into the traditional knowledge of the Buryats, and thus, unconsciously, I was enriching my own ethnic identity once again. But the research on Bair Dugarov made me feel more Buryat not only because I was learning 


\section{Galina Dondukova}

more peculiarities of Buryat history or traditional culture. I think the most important benefit of being an insider for me was that I could "understand the cognitive, emotional, and psychological precepts of participants" (Chavez 2008, 481) without stereotyping or underestimating them. In my case, I can say that my belonging to the Buryat community helped me to more closely render the underlying cultural meanings of Dugarov's poems. I could put myself in the place of his ordinary reader, who is a contemporary Buryat, speaks Russian instead of Buryat, and learns with great interest the hidden pages of Buryat history through his poems. I could feel it myself that the poetry of Bair Dugarov inspired and evoked pride in Buryatia. The nomadic images of the horse, the steppe, etc. were perceived as dear to the heart but lost, and caused nostalgia about the past of the Buryats. This emotional part of my research which is connected to the impressions I received from Dugarov's poetry, I think, also contributed to the strengthening of my ethnic identity.

The article represents my reflections about the issues of insider research. Using my own example, I try to show the researcher in-between, one who belongs to the community, but at the same time applies the methodologies of outsider analysis. My dissertation is, thus, an attempt to balance between both interpreting the poems as an insider and recognizing patterns as an outsider. What is more, my insiderness not only helped me in interpreting the poems but also influenced my own ethnic identity. The research on the revival of Buryat ethnic consciousness 
in post-Soviet Buryatia through the prism of Bair Dugarov's poetry actually led to a strengthening of my own ethnic identity. Strange as it may sound, it is nevertheless true: though performing my research in Poland, I felt more Buryat than I had ever felt in Buryatia.

\section{REFERENCES}

Amogolonova, Darima D., Irina E. Elaeva, and Tat'iana D. Skrynnikova. 2005. Buriatskaia etnichnost' $v$ kontekste sotsiokul'turnoi modernizatsii (postsovetskii period) [Buryat ethnicity in the context of socio-cultural modernization (post-Soviet period)]. Irkutsk: Radian.

Chakars, Melissa. 2014. The Socialist Way of Life in Siberia: Transformations in Buryatia. Budapest: CEU Press.

Chavez, Christina. 2008. "Conceptualizing from the Inside: Advantages, Complications, and Demands on Insider Positionality." The Qualitative Report 13 (3): 474-94.

Dondukova, Galina. 2019. The Settled Sorrow of Saddle: The Buryat Ethnic Identity in the Poetry of Bair Dugarov (PhD thesis). Warszawa: Wydział "Artes Liberales," Uniwersytet Warszawski.

Dugarov, Bair. 2007. Struna neba i zemli: Stikhotvoreniia [The string of Earth and sky: Poems]. Ulan-Ude: Respublikanskaia tipografiia.

Greene, Melanie J. 2014. "On the Inside Looking In: Methodological Insights and Challenges in Conducting Qualitative Insider Research." The Qualitative Report 19 (29): 1-13.

Khilkhanova, Erzhen, and Dorji Khilkhanov. 2004. "Language and Ethnic Identity of Minorities in Post-Soviet Russia: The Buryat Case Study." Journal of Language, Identity and Education 3: 85-100.

Nowicka, Ewa. 2015. "Towards the Creation of Modern Ethnicity and Imagined Community: Ethnofestivals and Constructing the Buryat Nation." Etnografia Polska 59 (1-2): 141-54.

Young, Alford A., Jr. 2004. "Experiences in Ethnographic Interviewing about Race: The Inside and Outside of It." In Researching Race and Racism, edited by Martin Bulmer and John Solomos, 187-202. London, New York: Routledge. 


\section{Ayur Zhanaev}

ORCID 0000-0002-8976-8811

University of Warsaw

\section{THE FALLING RAIN WILL STOP, THE GUEST WHO ARRIVED WILL LEAVE: ONCE AGAIN ON "INSIDER" AND “OUTSIDER" POSITIONS IN THE BURYAT FIELD*}

The fieldwork and the problems one encounters there are an integral part of the research, and an integral part of its description, as they illustrate the implementation of methodological knowledge in the field and disclose ethical issues of the work. In most of the cases, however, authors prefer to conceal this part of the research process, fearing to betray possible deviations from "ideal" methodological standards (Thøgersen and Heimer 2006 , 2). Indeed, the fieldwork as an integral part of a PhD students' learning process never follows forethought plans or meets all expectations, a fact which requires working out one's individual coping strategy (Saether 2006). Both successes and

* This article is a revised version of the introductory part of my PhD dissertation published as: The Human Being in Social and Cosmic Orders: Categories of Traditional Culture and the Problems of Contemporary Buryat Identity (Zhanaev 2019, 23-34). 
failures in the field could be useful in learning and drawing conclusions, which is richly described in scholarly literature (cf. Rabinow 1977). In my opinion, the process of gathering empirical data and the role played therein by the researcher's personality are an interesting topic to discuss. I would like to share my own fieldwork experience, with special emphasis on the researcher's position in the field and the knowledge to which one could have access owing to it.

I conducted fieldwork in different regions of ethnic Buryatia ${ }^{1}$ and in Mongolia, in close cooperation with my mentor Ewa Nowicka, as well as Wojciech Połeć and Blanka Rzewuska in 2012, 2013 and 2014; ${ }^{2}$ and independently during summer vacations between 2012 and 2016. My PhD project was dedicated to ideas of the social order in Buryat culture. This is not an issue that could be investigated through straightforward questions, but a topic that demands from the researcher considerable creativity and imagination to (re)construct/discover the theory used in everyday practices. Conducting the research itself could be seen as a sort of disturbance the order of things, as a "breaching" experience (Garfinkel 1991). One of the reasons that ideas of the social order, which were the main topic of my research, grasped me from the very first steps in the field was how very different the reaction of the field was

${ }^{1}$ A region in Southeastern Siberia, which includes the Republic of Buryatia and parts of Irkutsk Oblast and Zabaikalskii Krai.

${ }^{2}$ The research project led by Ewa Nowicka, entitled "Between Russia, Mongolia and China: Buryats and the Challenges of the 21st Century," was funded by the National Science Center (decision no. DRC-2011/03/B/HS6/01671). I accompanied the project participants only in Aga Okrug, Ulan-Ude and Kizhinga Aimag of the Buryat Republic and Khentii Aimag of Mongolia. 
THE FALLING RAIN WILL STOP, THE GUEST WHO ARRIVED...

depending on whether the researcher was a, loosely defined, outsider or insider.

\section{GUEST RESEARCHER IN BURYATIA}

Despite the controversial ways of its applications and the effects thereof, the Western scientific discourse could already be considered a common meaningful ground between the Western researcher and a non-Western community. This is not the 18 th or 19 th century, when the Western researcher could arrive in an "intact" community and draw a line between the scholarly and the local. The ideology of objectiveness and the privileged position of science (or anything with pretensions to the status of science) have already come into dialogue (unfair as it often is) with the local milieu and transported various ideas between these worlds. Thus, the academic categories and elements of sociological analysis are common discourses to be encountered in the Buryat field. This is what Anthony Giddens claims in his theory of double hermeneutics: "the 'findings' of the social sciences very often enter constitutively into the world they describe" (Giddens 1993, 150), and the other way round (Giddens 1993, 150-53). One should also add to this picture of the modern ethnographic encounter the common use of the Russian language as a factor facilitating interaction for the both sides. Moreover, in the case of Polish researchers, the common historical experience within the Russian Empire, influence of USSR policies and many other historical events make it impossible to consider fieldwork interaction in places 
like Buryatia merely in terms of "cultural differences." Rather, it is one link in the chain that is a history-long dialogue. All in all, therefore, I had a general impression that the distance between the Western researchers and the Buryat field is often exaggerated by both sides.

When I was offered a position of co-researcher and interpreter during the fieldwork of Polish anthropologists, I took it as a perfect opportunity to learn about their methodology and to gather my own field material. During my first visits to the field, I decided to see my work as an open-ended explorative project. I was overwhelmed with the conceptual cosmologies of these two worlds, that of the Polish social scientists and that of 102 their Buryat interlocutors, which, despite the processes of globalization and some common historical experience that I described above, were still very distant in many respects. The project of the Polish team was devoted to the modern cultural "canons" of Buryats living in Russia, Mongolia, and China. During the previous researches of Ewa Nowicka in Ust-Orda Buryat Okrug $(2000,2010)$ and in the Republic of Buryatia (1993 and 1994) she was constantly told about Aga Buryat Okrug as the most "traditional" Buryat region, where language and culture survived in the most undisturbed form in comparison to the rest of ethnic Buryatia. This was also the opinion I myself heard many times in regular life. I would like to emphasize this point here. I neither make or dispute claims about this region being more "traditional." This definition was "taken from the field."

My experience of accompanying foreign anthropologists acquainted me with the privilege and prestige that they enjoyed 
and that I later missed working on my own (see below). Foreign anthropologists were classified as "respected guests" and, to cite Uradyn Bulag's definition, important "cultural brokers" (Uradyn 1998, 6) that brought certain "outsider possibilities" (Young 2004, 192). Their position of "teachers" (bagsha) and scholars (erdemten) at university added more prestige than if they had been just regular guests, for having education (erdem) is traditionally a highly valued trait among the Buryats.

People in Aga Okrug were extremely helpful. Ewa Nowicka in her book The Roots of the Altargana Run Deep (Nowicka 2016), based on the material of this fieldwork, even called these conditions "luxurious" (Nowicka 2016, 9). Indeed, the local people did much to accommodate the "guests." In Aginskoe, the local administration even supplied us with transportation to get to the remote villages. In Duldurga, a local TV journalist shot a reportage about the Polish researchers for the local news channel and another journalist took an interview with them for a newspaper, so that when we visited other localities, many people already knew about us. We were shown all the key places of local importance, places of cult, and historic sites. I had the opportunity to watch the image and symbols of Buryatness that local people tried to present to the foreign guests.

In July 2012, we visited the town of Aginskoe in Aga Buryat Okrug during the opening of the Altargana International Buryat Festival, uniting the Buryats from Russia, Mongolia, and China. According to rough estimations, it gathered around 10,000 people. We were able to conduct interviews with guests who arrived from various parts of ethnic Buryatia and even 
with those living abroad. Importantly, we made contacts with people from other parts of Aga Buryat Okrug, whom we visited after the festival, during the remainder of our stay. In 2013, during our second visit to Aga Buryat Okrug, we decided to visit the remaining third part of the Okrug - Mogotuiskii District (Raion). Here, in the village of Mogotui, we used our own contacts from the Buryat State University and, again, the local administration helped us with transportation and accommodation. After that, we made shorter and longer visits to the villages of Usharbai, Zugaalai, and Kusochi. In every village, we were met by locals and accommodated in their homes, local school dormitories, and once even in 104 a Buddhist temple.

In 2014, we visited my home Kizhinga District in the Republic of Buryatia. This is another region treated as especially "traditional," where I spent most of my years from the kindergarten to the end of school. I had a network of relatives and acquaintances in this place. They were very helpful and took us to the important places of the region, offering their assistance and guidance. We visited a mass ceremony dedicated to Buddha Maitreya, in which more than 13,000 people gathered in Kizhinga, and a minor oboo ceremony in Ulzyte dedicated to the respected lamas from this locality.

After visiting Kizhinga, we continued our research in Mongolia in the predominantly Buryat village of Dadal in Khentii Aimag, where we had the opportunity to participate in the tenth edition of Altargana Festival. For me, it was an astonishing experience to see how a small village became 
full of various people sharing the same Buryat origin. Long lines of buses and cars were bringing in the participants from different regions of ethnic Buryatia, Mongolia, and China. We were also pleased to see people whom we knew from our previous fieldwork in Aga. They, too, were glad to see the Polish anthropologists once again, made pictures with them, and talked with them as old friends. There were many unidentified "friends" who would wave to us while driving past in buses and cars and we waved back to them in reply. I was also surprised to meet in Dadal my relatives whose grandfathers had migrated there from Kizhinga during the 1917-1922 Civil War in Russia. It is at such mass events that many Buryats have a chance to meet and communicate with their estranged kin. After the festival, we spent a few days in the village talking to local people. Apart from conducting interviews, a huge part of our research activity was dedicated to observation and participant observation.

During the fieldwork with the team of Ewa Nowicka, our informants were mainly representatives of the local elite. Since teachers (bagsha) have traditionally possessed high status in the Buryat society, we were often referred to them as to the best specialists in local culture. In the Buryat villages, teachers, apart from providing instruction in their main subjects, often volunteer organizing various workshops and the local cultural life more generally. For example, a math teacher was the person who organized the local museum, gathered artefacts, and taught museum lessons for children. Many teachers are also keen on researching local traditions and are respectfully 
called kraeved ${ }^{3}$ (local historian or regional ethnographer). Generally, the school and teachers could be called the center of the cultural life of a Buryat rural community. Apart from teachers and cultural workers, we conducted numerous interviews with representatives of local administration and religious institutions/cult - lamas and shamans - who also have enormous influence on the contemporary shape of the Buryat culture. In Ulan-Ude and Aginskoe, we met many cultural revival activists, artists, singers, and actors who eagerly shared their experience, plans and opinions on the issues related to Buryat culture. Of course, many people from outside the elite also made important contributions to our research.

Contacts with our Buryat informants always evoked panic among them. Clueless as to what to do, the Buryat hosts resorted to me for advice on how to treat the foreign guests from Poland. I was often asked about very practical things, like what they did and what they did not eat and drink, and how they might react to this or that thing. Many hosts felt uncomfortable because of their poor living conditions or unawareness concerning the topics their guests would be interested in, and I had to calm them down, explaining the cultural background of the European guests. The hosts also told me many things they never uttered to the guests directly, identifying me as an insider (manai Buriaad khübüün, "our Buryat boy/son," or niutagai khübü̈̈ "our native boy/son"). During the fieldwork, I often felt like a mediator (and interpreter) between

\footnotetext{
${ }^{3}$ Kraeved was also the status which was applied to me as to a researcher - and, most importantly, as a "local" researcher.
} 
the Buryat world and the world of the foreign guests, a world which I partly understood owing to my stay there as a student. By the time of our first visits, I had been learning Polish for three or four years and staying in Poland for couple of years, and I was able to translate ideas when it was necessary. I found priceless our conversations with Prof. Ewa Nowicka and Dr. Wojciech Połeć, who would share with me their thoughts and explain various aspects of anthropology and sociology. The border between our cooperation and friendship was getting more and more fluid and thus, perhaps, our work was all the more fruitful as well as sensitive (Nowicka 2012, 109).

I would not like to idealize the local hospitality, for of course both pleasant and unpleasant situations took place during the fieldwork. I also sometimes felt uncomfortable when I would notice some abrasive behavior. Various sensitive topics, like the attitude to World War II in Poland and Russia or the contemporary political situation, would also occasionally appear in our conversations (Nowicka 2014). During the three years of our visits, we could observe certain changes in views and attitudes, various other topics could gain currency - both the field and the researcher changes over time. Every such contact brings a new insight into the culture and serves as empirical material, and, despite all the trickiness and controversies, it certainly offers new opportunities and multiple perspectives to the experience of the culture.

I spent the fieldwork gathering not only empirical data, but also impressions, experience, and ideas which I developed during my further, independent fieldwork. While working on 
my own, I could see how the sense of the Buryat social order was subjectively important for me and for those with whom I made contact.

\section{“INSIDER" RESEARCHER'S EXPERIENCE}

The falling rain will stop, the guest who arrived will leave (Orohon boroo arilkha, erehen ailshan kharikha) - this popular Buryat proverb that I used in the title of the article shows the double-facedness of local hospitality. It means that one should exert every effort to make a good impression on a guest, comforting oneself in one's mind that his or her stay will not last for long. However, this recommendation does not regard those who were not classified as guests. Let me describe the other side of this proverb that I got to experience while doing research.

In the Buryat culture, one could commit a sin (nügel) by telling improper information (buruu iume khelekhe) which could disturb the order of events. It is one of the basic sins in the Buddhist view, along with the sin of improper intentions and improper deeds. I noticed that many people whom I met deemed themselves incapable of saying anything about their culture because they did not want to take on such responsibility. Especially when asked about religious issues, some of the people would recommend talking to another person or a lama. ${ }^{4}$ Apart from that, in the modern context, kraeveds, ethnographers and other scholars bear the same responsibility for

${ }^{4}$ Admittedly, analogous strategies are very common and could be observed also, for example, in Poland. 
producing knowledge as lamas, seniors, and wise and educated men traditionally did.

Kraeveds and ethnographers enjoy a high position in the Buryat society as specialists in the sphere of culture who have the authority to determine cultural canons and produce legitimate narratives of tradition and history. These are the specialists whom local people trust and on whom they depend in their undertakings aimed at the revival of the local cultural heritage. My position of a researcher of culture understood as categories of thought and as the scope of existing ideas was incompatible with the image of scholar they were used to. I was often blamed for lack of knowledge, for in the opinion of my informants, I asked very "elementary" questions. While the foreign anthropologists could feel free to ask about the meaning of commonly known practices, it was irritating when I did so. I heard some subtle comments like whether I read books and Buryat newspapers, because "everything was already written" there, and in any case, as a kraeved I should know a good deal more about the local culture than they did. The local people were very respectful of positivist, definite knowledge and suspicious about any questions indicating uncertainty. ${ }^{5}$ By asking them such questions, I definitely was marking myself as an outsider.

I was blamed even more for being not only a poorly educated kraeved but also a poorly instructed young Buryat, who was supposed to have learnt such things from his family and

${ }^{5}$ I am grateful to Prof. Andrzej Tymowski for pointing out to me the difference in academic cultures and its consequences. 
relatives. One of my uncles, who introduced me to a senior man for an interview, warned me not to ask "foolish" questions, as otherwise the man might not say anything, but would think in a bad way of me and my family. My informants also very often did not tolerate when I asked about the same thing twice, or was "chatting" too much, which is considered to be a "feminine" feature not appreciated much as a trait of a man's personality. Generally, the attitude to young men in the Buryat culture is sometimes very harsh. I had to consider such matters, since my gender, age, and family origin played a huge role in the extent of openness of the people I met. The configurations of being an insider or outsider seemed to me limitlessly relative.

There were of course people who were able to understand my methodological suppositions, yet among them, there were also some that were not contented with my research, for two reasons. This is best exemplified by my communication with one Buryat man. I asked him about the categories of kinship, which for him was elementary knowledge for a Buryat, thus after initial discontent with my ignorance, he started instructing me as an inexperienced young person. Soon due to the character of my sometimes quite subtle questions, he understood that I knew more than I pretended to. He was quite enraged after realizing this because he thought that I was just checking his knowledge and making fun of him. The second reason I found out after I explained properly that what I was trying to learn from him was his knowledge, his experience, and his opinion about the matter. After some considerations, he finally said that what I was doing was not a good thing because I was 
just spreading around rumors (khob sherekhe). Thus, gathering information "in the field" unexpectedly became another "sin" for me - spreading rumors, which is also considered a very impolite and "ugly" (muukhai) behavior. From this perspective, the work I was writing could indeed be seen as a collection of different rumors picked up from an enormous number of people in various situations, some of which happened long before I even thought about becoming a researcher. The position of insider researcher in the Buryat society challenges one to make a range of personal decisions, many of which I myself have not yet fully arrived at. My position implied a number of restrictions, and meant that I had to act in breach of many people's norms of politeness, and sometimes even of morality, with limited possibilities of being excused in comparison to an outsider. This circumstance, which contradicts the view that an "insider" position is more conducive for data collection (Young 2004, 188), determined my possibilities and strategy of research work in the field.

It is a common problem. The researcher asks about matters that lie on the surface, while thinking about their deeper meaning. As a person who was just learning to do independent research, gradually I tried to modify my strategy of coping in the field. Soon I understood all limitations of in-depth interviews in my case and became aware that the best methods for me to get information were observation and participant observation. This actually agreed with local behavioral tradition, as according to the Buryat cultural ideal, a young man like me should keep silent, talk less, and instead listen and 
watch what other people do and how they do it. Moreover, my position was strengthened by the role of a student who receives education far away from his homeland, somewhere in Poland. This was considered an extremely positive aspect of my personality - I was always encouraged, and some people I visited even granted me money gifts to support my education.

Thus, in the field, I lived my role of a young man who should be instructed and informants took on the role of teachers and elders. Therein probably lies a practical strategy to use to avoid angering your informants. However, a deeper, methodological question is at stake here - is it fair to pretend to ask about one thing, while really being interested in something else? I did not 112 try to hide my knowledge, since I did not want to be classified as a fool, but I courteously asked my informants to share their experience to help me in my research. They had to interrupt their routines to talk to me and were instantly asked if the conversation could be recorded, which as a rule they refused, fearing that their words might not be good enough to be heard somewhere far away in Warsaw. In most cases, I had to ask them, "Please, let me record you, I will need it badly in my study," and that sometimes worked. My own circle of relatives and acquaintances was extremely helpful, for I could rehearse the interviews with them, test, consult and negotiate many ideas. This was a strategy of getting knowledge that proved the most effective and most convenient for me psychologically. It was also important for me because, as I have mentioned, one cannot ask directly about the problem of the social order but can only extract knowledge about it through complex analysis. 
All in all, I got to know much about the ideas of the social order through disturbing it and synchronizing with it. Apart from the fieldwork, during my stay in Buryatia I lived an extremely active Buryat cultural life. I visited all possible exhibitions, museums, meetings, performances, local movies, concerts, theatrical productions, public debates, book presentations, conferences, religious ceremonies, and many other events to understand what was happening in the contemporary culture of the Buryats, who, as any other society in the world, are always in the process of change and searching their way. This was an almost paranoid state of finding, selecting and interpreting the meanings produced and negotiated in the culture.

\section{CONCLUSION}

What happened during my research project, however, was not restricted to the fieldwork and the analysis of literature on the topic. My knowledge, and my own position, were also significantly influenced by my stay in Poland as a PhD student. I could experience how the field was changing and how the researcher, myself, was changing, as well. The words of famous Polish linguist Anna Wierzbicka about her stay in Australia perfectly illustrate my situation:

One of the most important of these personal discoveries, which I owe to my life in Australia, was the discovery of the phenomenon of Polish culture. When I lived in Poland, immersed in Polish culture, I was no more aware of its specialness than I was of the air I breathed. Now, 
immersed in the very different Anglo (and Anglo-Australian) culture, I gradually became more and more aware of the distinctiveness of Polish culture (Wierzbicka 1997, 115).

During my stay in Poland, I made important observations on the social order of a distant culture, making comparisons, finding similarities and differences. I never thought of myself as purely "Asian" but as a person quite "assimilated" into the European culture. Yet despite the fact that throughout my whole life I was in regular contact with the Russian culture and language, and that the school and university I attended had Western curricula, my own conceptual cosmology is strongly rooted in my native culture. I had not realized that until I experienced on several occasions while living and studying in Poland the cultural differences between that country and Buryatia. I also highly appreciate the instruction of Prof. Stanisław Zapaśnik, who spent an enormous amount of time explaining to me various aspects of Polish, and generally European, culture.

On a more abstract level, I had the chance to study sociology, consult with researchers, and thus to negotiate and ground my theory. Such opportunity was also offered by the seminars, workshops and other events within the "Searching for Identity" project, led by Prof. Jan Kieniewicz, to which I owe a huge part of my reflections. Time and again, cooperation with Polish anthropologists allowed me to look at my own culture from different perspectives. It showed me the prospects and blockades of my own mind and the possibility to construct a certain distance to my own culture following the principle of methodological relativism (Zapaśnik 2010, 8), though I am fully 
aware that this relativistic demand is just as vague as the requirement to be objective.

One has to confess that despite aspirations to methodological objectivism, a researcher is never able to suspend his or her personal background and experience. This background, however, should not always be considered as an obstacle, blockade, but also as a foundation for the possibility of various ways of interpretation. I do not want to go into discussion on whether it is better to be an insider or outsider researcher. Each of these positions opens one sphere of culture and at the same time closes access to others. There are, furthermore, no clear measures of insider and outsider (Young 2004, 201). The advantage of my research was the opportunity it provided me to experience both of these loosely defined positions in their multiple manifestations. The multiplicity of these perspectives gives access to a multitude of meaningful contexts.

\section{REFERENCES}

Uradyn, Bulag. 1998. Nationalism and Hybridity in Mongolia. Oxford: Clarendon Press Garfinkel, Harold. 1991. Studies in Ethnomethodology. Oxford: Polity Press.

Giddens, Anthony. 1993. "Problems of Action and Structure." In The Giddens Reader, edited by Philip Cassell, 88-175. Stanford: Stanford University Press.

Nowicka, Ewa. 2012. "Friendship in Anthropological Fieldwork: Some Ethical Doubts." Lud 96: 109-22.

Nowicka, Ewa. 2014. "Wielka Wojna Ojczyźniana nad Ononem: Bohaterowie Okręgu Agińsko-Buriackiego w muzeach i obiektach pamięci” [The Grear Patriotic War on the Onon River: Heroes of Aga Buryat Autonomous Okrug in museums and sites of memory]. Kultura i Społeczeństwo 3: 131-49.

Nowicka, Ewa. 2016. Korzenie Attargany sięgaja głęboko [The roots of the Altargana run deep]. Kraków: Nomos.

Rabinow, Paul. 1977. Reflections on Fieldwork in Morocco. Berkeley: University of California Press. 
Saether, Elin. 2006. "Fieldwork as Coping and Learning." In Doing Fieldwork in China, edited by Maria Heimer and Stig Thøgersen, 42-57. Copenhagen: NIAS Press.

Thøgersen, Stig, and Maria Heimer. 2006. "Introduction.” In Doing Fieldwork in China, edited by Maria Heimer and Stig Thøgersen, 1-23. Copenhagen: NIAS Press.

Wierzbicka, Anna. 1997. "The Double Life of a Bilingual: A Cross Cultural Perspective." In Working at the Interface of Cultures: Eighteen Lives in Social Science, edited by Michael Harris Bond, 113-25. London, New York: Routledge.

Young, Alford A., Jr. 2004. "Experiences in Ethnographic Interviewing about Race: The Inside and Outside of It." In Researching Race and Racism, edited by Martin Bulmer and John Solomos, 187-202. London, New York: Routledge.

Zapaśnik, Stanisław. 2010. Patrzac z Tadżykistanu [Looking from Tajikistan] (unpublished book).

Zhanaev, Ayur. 2019. The Human Being in Social and Cosmic Orders: Categories of Traditional Culture and the Problems of Contemporary Buryat Identity. Warsaw: Wydawnictwa Uniwersytetu Warszawskiego. 

AND IN DISCOURSE 


\section{Olha Tkachenko}

ORCID 0000-0002-0777-7897

University of Warsaw; Institute of Slavic Studies,

Polish Academy of Sciences, Warsaw

\section{PERCEIVED IDENTITY: REAL \\ OBJECTIVITY OR DECONSTRUCTION \\ OF DISCOURSE?}

In almost every book or study on identity, one reads that it is a multifaceted phenomenon, characterized by different attributes depending on type and/or dimension. Hence, identity could be related to gender, ethnicity, ideology, political interests, language, religion, profession, and many other aspects.

In my $\mathrm{PhD}$ dissertation, I was trying to see how the identity of one nation (Ukraine) was being perceived by another nation (Poland) in its media discourse. From a sociological point of view, I was considering this as relations between an in-group and an out-group. In other words, I wanted to discern if there was a particular image of Ukraine in the Polish media, or if there was some kind of separate identity of Ukrainians as one group through the lense of the media discourse current among another group, namely the Poles.

To answer these profound questions, I started to research Polish opinion-forming press and its treatment of the subject of Ukrainian 


\section{Olha Tkachenko}

identity, using the theoretical paradigm of national identity studies and the methodology of Critical Discourse Analysis, which helped me to demonstrate the entire spectrum of social processes and orders of discourse related to the issue of identity.

The aim of my research was to investigate the main discourses of Ukrainian identity predominating in the Polish opinionforming press during the most significant social and political events in 21st century Ukraine, such as the Orange Revolution and Euromaidan. A distinguished place in my study was devoted to the theoretical and methodological part of the research, in order to introduce new forms of textual analysis of the media. In my research, I aimed neither to investigate what the Orange 120 Revolution and Euromaidan were as social phenomena and their meaning for further development of Ukraine, nor to explore the Polish-Ukrainian relations and mutual perception. Instead, I wanted to use the particular methodology of CDA to show how the Orange Revolution and Euromaidan had been perceived in the Polish press in terms of identity.

\section{THEORETICAL FRAMEWORK}

OF PERCEIVED IDENTITY

Before elaborating on identity studies, I would like to say a few words about the $\mathrm{PhD}$ program "Searching for Identity: Global Challenges, Local Traditions." As the very title of the program suggests, identity was a crucial concept not only for my academic development but on my way to finding myself, as well. Indeed, most concepts of identity are focused on the definition 
of the self and on retaining it over time (Ścigaj 2012, 51). Consequently, identity is researched through the sense of the "self," the studied people's own subjectivity. However, this theoretical framework could not be applied to my research of Ukrainian identity in the Polish press, for the obvious reason that its subject were not the carriers of the identity - but external observers. In short, my goal was to observe the observer. What is more, the task I took upon myself was not only to present a positivistic image of Ukraine in the Polish press based on cold empiricism, I wanted to understand why this image formed in one particular way and not another.

Why are Ukraine and Ukrainians portrayed the way they are in the Polish media discourse and what mechanisms does this reveal? It was during one of our first PhD seminars when I asked myself this question. We had two official languages of communication in our program - English and Russian. At the beginning of my $\mathrm{PhD}$ studies, I was the only Ukrainian in my group, the rest of the students were from different parts of Russia. Naturally, during the seminar my colleagues from Russia spoke Russian, and our Polish professors, who used to learn Russian at school during the time of the communist Polish People's Republic, had no problems understanding them. When it was my turn to express an opinion, I thought that the participants were expecting me, a Ukrainian, to speak Russian, too. Yet I found I could not say a word in Russian about more serious academic issues, my brain was generating words in English and it was much easier for me to participate in academic discussion in English than in Russian. That came as a shock to myself, 


\section{Olha Tkachenko}

as well, because I was sure that due to the post-colonial status of Ukraine and its long-time submission to Russia, I would be able to express myself freely in Russian on different topics, confirming thus the wide-spread stereotypes.

I started to wonder why I had problems with the Russian language in academia, despite never having had problems with simple communication in Russian. I am from the generation of people born in the USSR but brought up in independent Ukraine, in my case - western Ukraine. I have not learnt Russian at school, nor have I heard it in everyday life, either at home or at school. I just picked it up from the Russified mass media, reading Russian literature and Russian translations of world's classics which lacked Ukrainian versions. This sort of post-colonial way of learning language is how young Ukrainians know Russian. That is why I was surprised when other people thought that simply being Ukrainian automatically meant speaking perfect Russian. Very often in Poland people, having realized that I am from Ukraine, try to speak Russian to me, even though there is no need for that because I know Polish. This is meant as a polite gesture that is supposed to make me feel comfortable, and is based on the mistaken assumption that Russian is easier and closer for me. For that reason and many others, I decided to search for more theoretical knowledge about identity and to investigate the image of Ukraine in the Polish press, in order to understand what the perception of the Ukrainians in Poland was, and why it took on the form it took.

However, having set out to research Ukrainian identity in the Polish press, before formulating the research questions and 
hypothesis, I was troubled by a number of issues: What kind of identity do I research? How do I go about doing this? From what methodological and theoretical positions should I start my academic journey?

During one of my numerous consultations with Professor Jan Kieniewicz at the University of Warsaw, after listening to my reflexions, he said two words in Polish that set direction for my research: "tożsamość postrzegana," which translates into English as "perceived identity." These words prompted me to start my research from investigating the very notion of identity in social sciences. I needed to know what "identity" was in order to research "perceived identity."

Naturally, I started from learning what this notion was and how it had entered the public and academic discourse. As it turned out, identity's career in social science began relatively recently. First introduced by Sigmund Freud as one of his psychoanalytical concepts (Brubaker and Cooper 2000, 2), it then made its way to works on the psychopathology of the individual and then got popularized in the United States of the 1950s and 1960s by Erik H. Erikson (Ścigaj 2012, 51); today, it permeates not only the academic lexicon but that of journalism, as well (Brubaker and Cooper 2000, 2).

The main challenge for me was to work out a theoretical and methodological framework to apply to my empirical research of identity in the Polish press. The typology of identity in social sciences is based on the dimension of subjectivity. Subjectivity, in turn, is created through discourses (Taylor and Spencer 2004). Depending on the form and measure of subjectivity, there are 


\section{Olha Tkachenko}

two fundamental types of identity in social sciences: individual and collective. National identity, which I have chosen as my topic, refers both to the individual and the collective type of identity. In addition, a nation in the meaning of a people can be a subject and an object of identity (Ścigaj 2012).

In accordance with the type of nation, national identity is divided into civic and ethnic, hence, there are also ethnic and civic nationalisms (Sand 2009, 53). Based on this division, I started to create my code tree in order to get a close structural reading of the Polish press. I elaborated the structural elements of my code tree following Anthony Smith, who delineated five main features of national identity:

1. common historic territory, or homeland;

2. common myths and historical memories;

3. common culture;

4. common legal rights and duties for all members;

5. common economy with territorial mobility for members (Smith 1991, 14).

Common territory, culture and historic memories constitute the core of common origin of a certain ethnie and of its nexus with the nation-state. Speaking about ethnies (ethnic communities), Smith adds more features, three of which are: collective proper name, a myth of common ancestry, and a sense of solidarity for significant sectors of the population (Smith 1991, 21). Hence, ethnic identities are more exclusive and emphasize the uniqueness of the in-group (Smith 1986). Ethnic identity is regarded as comprising various components, including exploration, resolution, and affirmation of ethnicity 
(Umaña-Taylor 2011, 792). Overall, ethnic identity stresses primordial values - the special role of national culture, history and traditions (Phinney and Ong 2014) - and, as Holley Hansen and Vicky Hesli admit, it fosters the promotion of one's own sub-group to the exclusion of other groups (Hansen and Hesli 2009, 4).

Civic identity, on the contrary, is based not on ethnic attachment but on the group membership of residence and on tolerance of the other ethnic groups living in the state (Shulman 2004). Hence, civic identity is a subject of personal choice, to quote Liah Greenfeld, "membership in the nation in this case ultimately depends on one's will to be a member, and nationality, similarly to religion, may be both acquired and lost" (Greenfeld 2001, 2).

All these components of identity I sought in texts from the Polish press that dealt with Ukrainian issues, and then coded each case as the representation of either ethnic or civic identity.

However, national identity is a multifaceted phenomenon which relates to political and social life, ethnicity, nation, culture, and religion, to name just some aspects. In order to systematize the approaches to identity research, I referred to Polish sociologist Zbigniew Bokszański, who proposed to group national identity into several models (Bokszański 2008, 114-35):

1. the objectivist model;

2. model of discovered identity;

3. model of constructed identity;

4. model of identity as public opinion. 


\section{Olha Tkachenko}

Among the approaches and models of national identity, I found the model of constructed identity to be the most relevant for my study, which looked namely at the constructed images of Ukrainian identity as presented to the readers of the Polish opinion-forming press. Below I offer a review of the general objectives of the constructivist approach as applicable to my research on identity.

\section{WHO CREATES “US" AND "THEM"?}

During our $\mathrm{PhD}$ seminars we talked a lot about categorizing humans into "our" and "other people" and different ways of defining "us" and "them." This research attitude was compatible with the constructivist approach in identity studies, which I had chosen for my research. Shmuel Eisenstadts and Bernhard Giesen were among the first scholars to elaborate theoretical aspects of collective identity as a construct. In their article "The Construction of Collective Identity," Eisenstadt and Giesen (1995) made frequent reference to Durkheimian structuralism and the Weberian notion of Gemeinschaftsglauben (belief in communality). They proposed a general model for the analysis of collective identity and demonstrated strong arguments to be quoted in support of its constructionist character.

I decided to follow the ideas that were central to the seminar in my theoretical studies, so I paid attention to the issue of inclusiveness and exclusiveness, which is deeply intertwined also with searching for the Other in the identity-making process. The definition of who is Ours and who is Other or a Stranger is 
crucial to the transitory post-Soviet societies in their processes of identity-making and establishing symbolic boundaries (Barth 1998). One can find vivid examples of this in the intellectual discussions of the 1980s in countries throughout the Soviet bloc. The cornerstone question was about the belonging of these countries to Europe. Intellectuals identified the Ours with Europe, while the Other was embodied by the Soviet system. I found confirmation of this dichotomy in the Polish media discourse related to Ukraine. In the articles about European aspirations of the Ukrainians, they were perceived as definitely Ours. On the other hand, any manifestation of Ukrainian post-Soviet, pro-Russian identity was perceived as a display of Otherness.

\section{UKRAINIAN IDENTITY COMPLEXES}

\section{AND POLISH MEDIA DISCOURSE}

I realized that a general identity theory was not enough for my research. As I have already mentioned, I spent most of my life in western Ukraine. I grew up in a small village in the Carpathian Mountains, which was populated entirely by ethnic Ukrainians, but where there still was a spirit of the multicultural societies of Central and Eastern Europe. Although there are no Polish people anymore and an Orthodox church was built on the place of the village's Catholic temple, people still use the Polish word and say that they go to the kościót. Although the Soviets organized a sewing plant on the place of the Jewish temple, people still call this place "the synagogue." 


\section{Olha Tkachenko}

I went to a high school in the nearest big town of Drohobych, which despite its post-Soviet contemporaneity also had a Central European multicultural spirit. Drohobych is the birthplace of writer Bruno Schultz and academic Iurii Kotermak (Iuryi Drohobych), who studied medicine and liberal arts in Cracow and Bologna, and then was a professor of the Cracow Akademia (Jagiellonian University), and the rector of the University of Bologna in 1481-1482. Then I studied at the University of Lviv, where I was overwhelmed by, among others things, the diversity of contemporary Ukrainian literature, music and arts, which were very Ukrainian and European at the same time. Of course, I knew about other types of contemporary Ukrainian identity, 128 but I had not experienced them in my everyday life and in my surroundings. At that time, I associated them with the identity of big politics, of the then president Leonid Kuchma, it was the identity of the Russified capital of Ukraine, which had frightened me for a long time, it was the identity of oligarchic clans and corrupted state officials. But it was not my identity, and I never faced it directly - until the presidential election in 2004. At that time I was a first year student, being only 17 , I could not vote yet, and perhaps I should have been occupied with the studies and the approaching exams, but when, walking with my friend along Shevchenko Avenue leading to the Lviv Opera and Ballet Theatre on this snowy November evening, we heard about Viktor Yanukovych winning the second round, tears were in our eyes. We were frightened, frightened of being captured again and pushed back into the hands of the Empire. That was the first, most memorable and painful episode of 
facing this Other Ukrainian identity for me. After that, as history shows, there were many displays of this Other identity I had a chance to witness. Having grown accustomed to it, I decided to research Ukrainian identity in a more structural way.

Mykola Riabchuk, Ukrainian scholar and essayist, has rightly claimed that from the perspective of identity-making processes, Ukraine is the most ambiguous of the post-communist states that went through the transition of 1989-1991 (Riabchuk 2012). This complicated my research even more, and as I started to explore Ukrainian identity-construction process, I tried to choose a suitable paradigm to provide a more structural framework for my analysis. ${ }^{1}$ Eventually, I found it in Stephen Shulman's theory of identity complexes (Shulman 2004).

It is obvious that in Ukraine, like in other post-Soviet states, national identity depended on supranational orientation - the choice between Russia and Europe or the West, whatever the latter meant in different periods of independent Ukraine. Thus, next to national identity, supranational identity became the second identity category in my research paradigm and my code book. The connection between Ukrainian national and supranational identities is clearly illustrated by Stephen Shulman, who does so by distinguishing two identity complexes: ethnic Ukrainian national identity, which he links with orientation to Europe and the West, and Eastern Slavic national identity with orientation to Russia (Shulman 2004, 45). So, following Shulman, when I found in the Polish press texts about Ukraine

${ }^{1}$ I have already presented some results of my analysis in the articles: Tkachenko 2016a, 2016b. 


\section{Olha Tkachenko}

comparing it to other Central and Eastern European countries, I coded this as European ethnic identity. Despite the presence of ethnic elements, some researchers characterize this type of identity as an inclusive civic one, albeit with a strong component of national cultural adherence (Riabchuk 2012). This was also confirmed by Shulman in his another article, where he analyzed Ukrainian identity complexes and the tendency to support changes and reforms in social and political life. Shulman discovered that the people in the group that was coded by him as "ethnic Ukrainians" were more likely to participate in civic life and support social changes towards democracy (Shulman 2005).

The Eastern Slavic ethnic national identity complex, on the 130 other hand, assumes that the Ukrainian nation is founded on two primary ethnic groups, languages, and cultures - Ukrainian and Russian. One variant of the Eastern Slavic identity is post-Soviet identity, which derives from the quintessential (post-)Soviet man, or homo Sovieticus. This identity is characterized by a weak feeling of culture and ethnicity. Representatives of the post-Soviet identity often regret the dissolution of the USSR and speak neither the Ukrainian nor the Russian language but their mix, called surzhyk (Melnykovska, Schweickert, and Kostiuchenko 2011). Whenever I found a representation of Ukraine and Ukrainians in the Polish press that fit this description, I coded it as pro-Russian, post-Soviet identity.

I also realized even more that the supranational identity played a crucial role not only in terms of contemporary preferences of foreign orientation but in the historical discourse, as well. Whereas Russia influenced the pro-Soviet category of Ukrainian 
identity, Poland facilitated the tendencies in the Ukrainian national context to connect with Europe. Analyzing the process of Ukraine's transition to a modern nation-state, historian Roman Szporluk proves the kinship of Ukraine and Europe in terms of institutional structures by demonstrating the existence of the so-called European idea in the Ukrainian historical and intellectual discourse (Szporluk 1997), current especially among the intelligentsia, who first realized that Poland "knows a shorter road to Europe, in particular to its liberal and democratic ideas and institutions" (Szporluk 2007).

The idea of Europe found a wider reflection in the cultural context and public intellectual discourse. Ukrainian writers and scholars emphasized that the European idea could be inscribed into the Ukrainian identity frame through the notion of "Central and Eastern Europe," as it had been done by intellectuals of other countries of the former Soviet bloc (Hnatiuk 2005). In this case, Europe and its identity were perceived in Ukraine mostly in two different dimensions: Europe as an institution and Europe as an idea (Yermolenko 2014).

With the idea of identity complexes, my theoretical framework regarding perceived national identity of Ukrainians was complete. What was left now was to apply to it the methodology of Critical Discourse Analysis. I chose discourse as a crucial category for two reasons. Firstly, I think that the analysis of media discourse opens up a broader understanding of the role of mass communication in contacts between the two states. Ordinary people form their views about the world mainly from the mass media, hence an awareness of how 


\section{Olha Tkachenko}

Ukrainians and their identity are perceived in the Polish public discourse could be useful for further international relations, reconciliation, and better understanding between the people of Poland and Ukraine.

Secondly, I find discourse to be the most appropriate tool to study the perception of the identity of one group in the environment of another group. According to Ernesto Laclau and Chantal Mouffe's theory of discourse (Laclau and Mouffe 1985), every social process, including identity construction, could be understood through discourse, which in their view is not limited to linguistic phenomena only. What is more, Laclau and Mouffe claim that certain notions or structural elements of reality do not 132 possess meaning in and of themselves, but acquire it through discourse. In other words, it is only through discourse that some portions of reality can be perceived as a separate phenomenon or entity, and consequently become "an issue" or "a problem." With that in mind, to learn how Ukrainian identity was pictured in the Polish press, I combined classical content analysis with Critical Discourse Analysis of the written text. These two approaches enabled me to link both quantitative and qualitative methods. The analysis of the textual samples was based on the selection and coding of the texts. For this analysis I chose all paper-based articles about Ukraine in the Polish opinionforming weeklies during the period of Orange Revolution and Euromaidan. After excerpting qualitative data from the content, the textual samples were coded to prepare them for further qualitative analysis with the help of CDA. Generally speaking, I used four main analytical tools of CDA. In most cases, 
the samples were analyzed according to Norman Fairclough's basic principles of critical analysis of the discourse: description, interpretation, explanation (Fairclough 2001). Then I analyzed texts on the issues of identity using Ruth Wodak's approach to the analysis of discursive construction of national identity, which encompasses the analysis of strategies and of personal, spatial, and temporal references (Wodak et al. 2009). Simultaneously, one of the core elements which constituted my analysis of the perception of Ukrainian identity in the Polish press was the analysis of the actors of identity proposed by Theo van Leeuwen (Leeuwen 1995). Finally, I analyzed the narrative. I also created specific tree of codes, which helped me to make my analysis of Ukrainian identity in the Polish press more structural and objective.

\section{CONCLUSION}

My PhD studies have taught me that it is very important to choose a specific category for your analysis, otherwise it is very easy to get lost in the numerous concepts and theoretical and methodological approaches. In this brief summary of my backstage research process, I strove to show how both the process of my professional training and my experiences that preceded it led me to devise a solid quantitative and qualitative research method and, consequently, to discover the perceived identity of Ukraine. Perceived identity is the identity constructed not in the environment of the identity-carrier, but by the observer, by the Other. It is similar to Edward Said's concept of Orientalism, but unlike 
Said's notion, it can be applied not only to the colony-colonizer and center-periphery dichotomies, but to a wide range of social structures. In my study, perceived identity was discovered in the media discourse with the help of the methodological tools of CDA. To answer the question stated in the title of this paper: texts about Ukrainian issues in the Polish opinion-forming press create a particular discourse with the help of which the identity of one group (Ukrainians) is constructed in the environment of another group (Poles). Perceived identity, like regular identity, is also a construct. Therefore, it may vary depending on the preferences of the readers. As agenda setters, the media create particular discourses of identity. Thus, in the media discourse, perceived identity becomes real subjectivity.

\section{REFERENCES}

Barth, Frederik. 1998. "Introduction." In Ethnic Groups and Boundaries: The Social Organization of Culture Difference, edited by Frederik Barth, 9-38. Longe Grove: Waveland Press.

Bokszański, Zbigniew. 2005. Tożsamości zbiorowe [Collective identities]. Warszawa: Wydawnictwo Naukowe PWN.

Brubaker, Rogers, and Frederick Cooper. 2000. "Beyond 'Identity." Theory and Society 29 (1): 1-47.

Eisenstadt, Shmuel Noah, and Bernhard Giesen. 1995. "The Construction of Collective Identity." Archives Européennes de Sociologie 36 (1): 72-102.

Fairclough, Norman. 2001. Language and Power. Harlow: Longman.

Greenfeld, Liah. 2001. The Spirit of Capitalism: Nationalism and Economic Growth. Cambridge, MA: Harvard University Press.

Hansen, Holley E., and Vicki L. Hesli. 2009. "National Identity: Civic, Ethnic, Hybrid, and Atomised Individuals." Europe-Asia Studies 61 (1): 1-28.

Hnatiuk, Olia. 2005. Proshchannia z imperiieiu: Ukrains 'ki dyskusii pro identychnist' [A farewell to the empire: Ukrainian discussions about identity], translated by Marta Boianivs'ka. Kyiv: Krytyka. 


\section{PERCEIVED IDENTITY: REAL OBJECTIVITY...}

Laclau, Ernesto, and Chantal Mouffe. 1985. Hegemony and Socialist Strategy: Towards a Radical Democratic Politics. London: Verso.

Leeuwen, Theo van. 1995. "The Representation of Social Actors." In Texts and Practices: Readings in Critical Discourse Analysis, edited by Carmen R. CaldasCoulthard and Malcolm Coulthard, 32-70. London, New York: Routledge.

Melnykovska, Inna, Rainer Schweickert, and Tetiana Kostiuchenko. 2011. "Balancing National Uncertainty and Foreign Orientation: Identity-Building and the Role of Political Parties in Post-Orange Ukraine." Europe-Asia Studies 63 (6): 1055-72.

Phinney, Jean S., and Anthony D. Ong. 2007. "Conceptualization and Measurement of Ethnic Identity: Current Status and Future Directions.” Journal of Counseling Psychology 54 (3): 271-81.

Riabchuk, Mykola. 2012. “Ukraine's 'Muddling Through': National Identity and Postcommunist Transition." Communist and Post-Communist Studies 45: 439-46.

Sand, Shlomo. 2009. The Invention of the Jewish People, translated by Yael Lotan. London: Verso.

Ścigaj, Paweł. 2012. Tożsamość narodowa: Zarys problematyki [National identity: An overview]. Kraków: Księgarnia Akademicka.

Shulman, Stephen. 1999. "The Cultural Foundations of Ukrainian National Identity." Ethnic and Racial Studies 22 (6): 1011-36.

Shulman, Stephen 2004. "The Contours of Civic and Ethnic National Identification in Ukraine." Europe-Asia Studies 56 (1): 35-56.

Shulman, Stephen. 2005. "National Identity and Public Support for Political and Economic Reform in Ukraine.” Slavic Review 64 (1): 59-87.

Smith, Anthony. 1986. The Ethnic Origins of Nations. Oxford, Cambridge: Blackwell. Smith, Anthony. 1991. National Identity. Harmondsworth: Penguin Books.

Szporluk, Roman. 1997. "Ukraine: From an Imperial Periphery to a Sovereign State." Daedalus 126 (3): 85-119.

Szporluk, Roman. 2007. "The Western Dimension of the Making of Modern Ukraine." Institut für die Wissenschaften vom Menschen website. Accessed August 15, 2019. https://www.iwm.at/transit-online/the-western-dimension-of-the-makingof-modern-ukraine/

Taylor, Gary, and Steve Spencer. 2004. Social Identities: Multidisciplinary Approaches. London: Routledge.

Tkachenko, Olha. 2016a. "The Perception of Ukrainian Identity During Euromaidan in Polish Opinion-Making Press." Studia Medioznawcze 1 (64): 75-85.

Tkachenko, Olha. 2016b. "Reinventing Ukraine: Ukrainian National and Supra-National Identity in Contemporary Polish Opinion-Forming Press." Colloquia Humanistica 5: 141-63.

Umaña-Taylor, Adriana J. 2011. "Ethnic Identity.” In Handbook of Identity Theory and Research, edited by Seth J. Schwartz, Koen Luyckx, and Vivian L. Vignoles, 791-809. New York: Springer. 
Wodak, Ruth, Rudolf de Cillia, Martin Reisigl, and Karin Liebhart. 2009. The Discursive Construction of National Identity, translated by Angelika Hirsch, Richard Mitten, and J. W. Unger. 2nd edition. Edinburgh: Edinburgh University Press.

Yermolenko, Volodymyr. 2014. "Dreams of Europe," translated by Jim Dingley. Eurozine, February 6. Accessed November 21, 2014. https:/www.eurozine.com/ dreams-of-europe/ 


\section{Irina Koluzaeva}

ORCID 0000-0002-2685-4288

University of Warsaw

\section{LIFE STRATEGIES IN A WARTIME \\ BORDERLAND: PROBLEMS OF}

IDENTITY OF PEOPLE "IN BETWEEN"

ON THE EASTERN BORDER OF THE

GRAND DUCHY OF LITHUANIA

DURING THE LIVONIAN WAR

This article is written on the basis of my $\mathrm{PhD}$ research, which was devoted to Filon Kmita Czarnobylski - Captain (Starosta) of the borderland Castle of Orsha and Palatine (Voivode) of Smolensk (b. 1530, d. 1587). This person was chosen for the purposes of researching an identity which faced global challenges: born an Orthodox Ruthenian nobleman in the preReformation Grand Duchy of Lithuania, he took part in military conflicts against Russia ruled by Ivan the Terrible, and was an eyewitness to the Union of Lublin and the Reformation. Above all, however, the very fact of being a citizen of the PolishLithuanian Commonwealth can be said to have made him a man of the borderland, as it has been a common approach to consider this entire territory as a borderland (Kenevich 2011, 98-103). 
After looking through many sources of different types related to this topic, I understood that even this most formalized ${ }^{1}$ part of the border between Smolensk in Muscovy and Orsha in the Grand Duchy of Lithuania, in the researched period (soon after the Union of Lublin of 1569), to some extent still remained a borderland. And it was not only the person of this state officer which made me think about this territory as a borderland, but rather those "smaller" people whom I met in correspondence, in diplomatic documents, different reports and other types of sources. I used these sources extensively in my main research, yet after finishing it, I realized that there were so many issues connected to the borderland society which fell outside the scope of my $\mathrm{PhD}$ research and which were nevertheless still a part of the main topic of my studies - borders and the borderland. That is why I decided they should be discussed.

When a historian has to deal with identity research, he or she encounters various problems which are probably unfamiliar to anthropologists, sociologists etc. A historian has to do mostly with written or material sources, and it is regarding those sources that he or she has to be able to ask proper questions. This does not mean that the historian has no tools with which to research someone's identity. The first thing we should admit, however, is that we are not always sure what type of identity we are looking for. Sometimes we find ourselves in need to "ask" our subject's contemporaries, one by one, in order to form a bigger perspective. For instance, while it is quite easy to 
establish religious identity of a person, when it comes to his or her national identity, things become more complicated: in my research I dealt mostly with Ruthenian nobility, and the main problem in revealing their identity was that there were no certain criteria of nationality applicable to this period and this society. There is always the possibility to use Benedict Anderson's idea of "imagined community" in order to find out the group identity of the person. However, in my opinion, it is almost impossible to find the self or the ipse identity (Ścigaj 2012, 30-31) of a person from the past. The reason is simple - most sources appeared in certain circumstances and are pre-determined by those circumstances. They did not give their author much possibility to express him- or herself, or to provide answers to the most important existential questions.

The best approach is still the anthropological approach, started in the mid-20th century, or the microhistorical approach (Domańska 2011, 218-25), which focuses on smaller groups or societies and also includes a number of anthropology-derived methods. The research process has to be a dialogue conducted by historian not only with a written source, but also with the person who is behind the text of this source, in order to understand their point of view and motivation. However, we should always bear in mind the cultural difference between the researcher and his or her "interlocutor." That is why I chose the microhistorical approach both in this paper and in my $\mathrm{PhD}$ research.

Below, I am going to focus more on the ideas of the border, borderland and population of the borderland, which were developed in the works of Jan Kieniewicz. Regarding 
the modes of coexistence and conflict in the borderland, he wrote, "not always the consciousness of the presence of the Aliens beyond the border led to a confrontation, which would bear as fruits new forms of the civilization" (Kieniewicz 2005, 21), adding that, "a considerable part of Intermarium territory consisted of the typical borderland, where fights were constant, simultaneously with the commercial relations and cultural exchanges" (Kieniewicz 2005, 32). According to Kieniewicz's assertions, dialogue is one of the most important features of the Civilizational Borderland, a territory which is best understood in categories of "imagined societies" (Kenevich 2011, 9-10).

I would like to devote this article to those "small people" whose behavior tells us so much about strategies of life in the borderland that (despite many challenges) still existed in the period in question on the Eastern Frontier of the Grand Duchy of Lithuania. I am going to discuss different strategies chosen by the local denizens in a time of conflict. I believe that they were not barely voiceless witnesses to those events but could participate in them in different ways, and those strategies reveal that in the mid-16th century the borderland had not yet disappeared on this territory. I want to prove that the "Borderland" in its literal meaning was understood by its inhabitants as a peculiar community and peculiar space, and constituted a type of imagined community and imagined space which created specific border identity and different types of encounter, not only conflict but also a dialogue (Kieniewicz 2005, 11). 
One of the most significant researches of the last years regarding this problem was made by Mikhail Krom. His study discusses the border society of the first half of the 16th century (Krom 2010). This topic was also raised by Andrei Ianushkevich in his study about the first period of the Livonian War (15581570) (Ianushkevich 2013, 323-39). He focused on different issues related to the condition of the local population: relations of the Moscow government with the population of Polotsk after the area was seized by the Muscovites in 1563, attitude of the locals towards the requirement of defending their own land and castles, cases of treason, and migrations from devastated territories. The main conclusions of this chapter of Ianushkevich's work are that the "presentiment of war" developed on this territory a specific "way of life, where the main purpose of the common people was to save their own life and property in every circumstances" (Ianushkevich 2013, 339). The author also states that there is no evidence to justify speaking about any ideological patriotism among the peasants, and if patriotism did manifest itself, it was only an expression of loyalty toward their feudal lord (Ianushkevich 2013, 327, 339).

The border between the Grand Duchy of Lithuania and Muscovy experienced many changes in the 16th century. The Smolensk-Orsha section of the border was set by a treaty of 1522. After more than 100 years of being part of the Grand Duchy of Lithuania, Smolensk officially became a part of Muscovy for the following almost 100 years. ${ }^{2}$ The next war

${ }^{2}$ Smolensk was taken by the military forces of Tsar Vasili III in 1514, with the treaty formalizing this fact in 1522 . 
happened in 1534-1537, but it did not alter this part of the border. It is impossible to speak about any pro-Moscow sentiments among the population of Smolensk in 1514, when the city was taken by the Muscovite army (Krom 2010, 219). After a war started in Livonia in 1558, new conflict broke out between Moscow and the Grand Duchy of Lithuania in April 1562, with very intense fighting up until the treaty of 1570 and then again in 1579 during Stephen Bathory's campaign.

Most local people did not usually take any active stance in or in regard to the warfare, and life decided for them whether they would become refugees because their houses were ruined and their villages razed, a fate that befell significant parts of 142 the Polotsk Palatinate (Ianushkevich 2013, 334-39).

However, there were people who actively took part in what was happening on the border: especially those whose service was directly connected to the border castles - scribes, judges, and castle servants.

Due to its diplomatic function, the Castle of Orsha was always in need of specific servants: attendants (pristavs - people who escorted diplomatic missions from the border to their final destination), military escort for some of the diplomats, guides (people with very good knowledge of the locality), couriers for quick exchange of correspondence with the opposite side, as well as merchants, spies and agents, etc. The locals were engaged in these activities in different capacities. Thus, while on the one hand, war destroyed these lands and many settlements, on the other hand, it created many new "borderland-related" activities. 
The borderland is not only a space of constant encounter but one of constant potential conflict, as well. Thus, the Muscovite-Lithuanian border was not only a space of larger conflict between states, or if we take into consideration Jan Kieniewicz's point of view - civilizations, but was also full of conflicts on a minor scale. At the risk of sounding controversial, one might say that those conflicts were "internal" to the borderland, and it is only when considered in the categories of a clash of two major polities, such as Muscovy and the Grand Duchy of Lithuania, that they receive the status of international conflicts. As noticed by Belarusian historian Viktor Temushev, who studied the history of Homel Land, the everyday life of that society was overshadowed by those "wrongs, provocations and harms" (Temushev 2018, 167-68). Such smaller conflicts were a permanent feature of the borderland - they are often mentioned in books of diplomatic records in the form of "lists of wrongs," exchanged by both sides (Karpov 1887, 321). For example, in 1550, King Sigismund Augustus wrote to Tsar Ivan IV that he had received many letters from border starostas (local administrators whose responsibilities included law enforcement), complaining about damage caused by people from borderland Muscovite towns (Karpov 1887, 335). In response, Ivan IV sent a similar list which contained cases when the Lithuanian Cossacks robbed citizens of Muscovite border towns, stealing horses and other property. Such situations occurred along the whole border (Karpov 1887, 345-47). This activity did not stop throughout the period leading up to the war, even when it was crucial for both central 
governments not to provoke unnecessarily the aggression of the opposite side.

Book 564 of the Lithuanian Metrica preserved many letters from the King to border starostas from the first years of the Livonian War (the earliest of them date to 1561). Sigismund Augustus repeatedly warned the border starostas against causing any harm in the Muscovite lands (Baliulis 1996). The government of border towns had to be able to control local citizens as well as Cossacks, a military formation which existed not only on the territory of the Zaporozhian Host, but was also an integral part of the borderland society (as defensive military units). As diplomatic records show, most of mutual damage in earlier 144 times had been done by these military formations. When the local administration was able to control the military activities of Cossacks, it assigned them with different tasks. Cossacks could not only collect intelligence, but were often sent to capture prisoners from whom to extract the necessary information (Dyplomatariusz 1910, 192, 223). However, controlling them was not always possible: the Cossacks sometimes mounted their raids on villages in Muscovite lands even when it was crucially important to maintain peace on the border.

In 1568, the Starosta of Orsha complained to the Field Hetman that a Cossack band led by a man named Sevriuk was, on their own initiative, attacking Muscovite people and that the Grand Duke of Moscow would probably retaliate (Dyplomatariusz 1910, 155). Such activities endangered the civilians on the Lithuanian side of the border, who were the ones to complain about the raids to the starosta. 
Offensives of this kind were also carried out by the Moscow side: in 1566, Sigismund Augustus informed Ivan IV that one of Lithuanian officers had written to him from the border to complain about Muscovites raiding the Lithuanian lands, killing people, taking captives, and seizing property (Karpov 1892, 383).

Then came war, which created new ways to get rich. The character of many of the military expeditions carried out in this territory in the 1560 s allowed their participants to count on some spoils of war. As diplomatic documents show, even representatives of the Lithuanian nobility who headed those expeditions took captives with the purpose of receiving head money for them (Karpov 1892, 464).

Yet it was not only military activity that occurred on this border. Orsha lay on the main road between Moscow and Vilnius. Its everyday function in the 16th and early 17 th centuries was connected to different cross-border activities. War and the peace negotiations that it eventually led to created a lot of small but very important roles in diplomacy and intelligence: couriers, spies, runners etc. Sources from both sides of the conflict preserved names of some of those people.

The importance of intelligence on the eastern border was indicated by the King already at the beginning of the war. Border starostas had to coordinate this activity (Baliulis 1996, 69, 89-95, 120-21). In Orsha, there were different types of people engaged in obtaining surveillance information - couriers, local spies, Muscovite spies, attendants etc. Spies were recruited especially for carrying out reconnaissance, and were paid regularly. The problem of payment for their service was so important 
that in 1567, after the Starosta of Orsha left the castle without securing funds to pay the spies, its Captain Bohusz Sielicki was afraid the fortress would " remain deaf and without news" because spies would go to work for Moscow (Dyplomatariusz 1910, 171).

This shows that spying became for its performers not only a choice but a sort of craft and profession, as well. Let us take a closer look at those who are known from sources for being spies on this territory and what their motives could have been.

The border starostas were responsible for exchanging correspondence with the opposite side, and the Starosta of Orsha had to correspond with the Voivode of Smolensk on diplomatic issues, such as arrivals of emissaries, meetings on the border etc. Any possibility of sending a courier to the enemy's land was used for the purpose of receiving information from that side: usually the courier met with some anonymous "allies," who told him what they knew about the current situation in their country and its possible military designs. In 1569, the Starosta of Orsha wrote to the Voivode of Smolensk offering an exchange of prisoners: captives from Izborsk who were imprisoned in the Grand Duchy of Lithuania were to be traded for people from Polotsk held in Moscow. The Voivode sent an answer to Orsha with two couriers: Tyshka Lomakin and Bohdan Kopylo. When those couriers returned to Smolensk, they informed about preparations of a Polish-Lithuanian diplomatic mission and about the planned sending of Lithuanian military forces in the direction of the border (RGADA, f. 79, op. 1, reestr 2, d. 2, [stolbets] 1569, 1-8). 
Several years later we meet one of those couriers - Tyshko Lomakin - in the correspondence of Filon Kmita, the Starosta of Orsha, already as a Lithuanian spy. Kmita passes on information about the Cheremis and Nogai troops which Moscow was going to send to the Lithuanian border, and to lend credibility to his sources, he refers to the person of the witness: "Lomakin is a long time spy of mine, and earlier he gave me lots of dangerous messages and warnings" (Przezdziecki and Malinowski 1844, 261). From Filon Kmita's letter we know that this time Lomakin passed information along to the Starosta through Orsha's denizens, adding that the Voivode of Smolensk was looking for him and that he [Lomakin - I. K.] would probably be sent to the Tsar. Lomakin asked to pass all this information to the Starosta of Orsha and admitted that, "For us it would be better if there was peace between the monarchs" (RGADA, f. 79, op. 1, reestr 2, d. 2, [stolbets] 1569).

A similar case from the opposite side was noted by a document of the Muscovite Ambassadorial Office. When the mission of Moscow's emissary Gregory Nashchokin was returning to Moscow, the moment the Muscovite ambassadors and their entourage crossed the border, boyars kidnapped one of the Lithuanian guides who escorted the mission, whose name was Maksymko Hohol. The Lithuanians, in their turn, kidnapped a Muscovite guide. As I established on the basis of records of the Muscovite Ambassadorial Office, before this incident, Hohol was an informant of the Moscow intelligence: in February 1580, he met at the border with spies from Smolensk and gave them information about Lithuanian military plans (RGADA, 
f. 79, op. 1, reestr 2, d. 2, [stolbets] 1569, 74-75). For some reason, he evoked anger of Ivan IV, who ordered to abduct him. Eventually, this episode even became a topic of correspondence between King Stephen Bathory and Tsar Ivan IV (Pogodin and Dubenskii 1843, 85). In Moscow, Maksymko had to endure examination led personally by Tsar Ivan, who finally decided to have him tortured. After tortures he was sentenced to death, but in the end somehow he managed to escape and go back to the Grand Duchy of Lithuania.

During the first stage of the Livonian War, very intensive spying activity took place in the Lithuanian town of Dubrovno, not far from the Muscovite border in Vitebsk Voivodeship. Orsha's Starosta complained to the Hetman that a lot of wrongdoing occurred in Dubrovno (Dyplomatariusz 1910, 133-34; Ianushkevich 2013, 330-31), meaning by this that a lot of people collaborated with the enemy's spies. I think that the reason for this situation should be looked not only in pro-Moscow sentiments of the inhabitants but, in this particular case, also in the fact that Dubrovno belonged at that time to Jan Hlebowicz, who was an informant for Ivan IV.

Collaboration with the enemy was also determined by strong relations with informants on the other side. Often we can see the same people crossing the border multiple times in order to deliver correspondence from one side to the other. During their missions, they met with "friends" on the opposite side and obtained necessary information. One of notable couriers for Orsha's starostas was Ilia Poltev from Orsha. His friends or relatives must have not been resettled from Smolensk Land by the 
Moscow government, which allowed him to visit them during his trips to the Muscovite territories. In November 1568, Poltev met with them and passed on important information to Orsha Castle's commander Filon Kmita. On the other side of the border, Andrei and Hrehory Poltev from Smolensk, possibly connected to Ilia, are met at service of the Grand Duke of Moscow. The Poltevs were one of the most prominent Smolensk boyar families in the late 15th century (Krom 2010, 235), however in 1514, when Smolensk was taken by the Muscovites, they left the city for Lithuania, where they received land grants from King Sigismund I.

This shows that even in the second half of the 16th century, old relations and connections still existed and played an important role in transborder dialogue.

The third important reason which inclined some Muscovites to collaborate with Lithuanians was the politics of Ivan IV. People were unhappy with the oprichnina, which in their perception was worse than Tartar invasions. Opinions like this were sometimes voiced unofficially by Muscovites in conversations with their Lithuanian allies (Dyplomatariusz 1910, 273).

But collaboration with the opposite side did not always find expression in spying, sometimes the emissaries tried to communicate with the Muscovite government through their attendants. One such instance happened in 1553, when the Lithuanian mission of Stanislaw Dowojna, Ostafi Wołłowicz and Piotr Semaszko visited Moscow. One of Dowojna's servants - Paweł Kozicki - told their Muscovite attendant, "We are borderland lords, we live in the borderland; and whatever 
deal your sovereign wants to be done - it will be done" (Karpov 1887, 384).

Not only ordinary guides or officers of the lower ranks are noticed in such roles, but even those ranking much higher. Of course, I do not mean the well-known cases like those of Andrei Kurbski or Semen Bielski, who are known for changing their sovereign, or even the case of Jan Hlebowicz, who did not change the country, but did pass secret information to Ivan IV for a long time. These examples are not applicable here because those people were more connected to the person of the sovereign, they did not have to live their life on the border, and so the mechanisms of their choices were different.

Rather, an applicable example is to be found in a Muscovite book of diplomatic records. In 1586, the next Tsar, Fedor Ivanovich, sent to Lithuania his ambassadors - Fedor Pisemski, Fedor Troekurov, and Druzhyna Petelin. On their way back to Moscow, they called one of their Lithuanian attendants, the Orsha scribe Andrei Voropai, and asked him to explain why Lithuanian lords [Panowie Rada] did not want to negotiate perpetual peace but required the cession of Smolensk and some other lands. The Muscovites noted that earlier Voropai had served a good turn for the Grand Duke of Moscow, ${ }^{3}$ and they asked him to do it again by telling them what he knew about the position of the Lithuanian Council of Lords. Voropai was aware that he should not disclose the information to Moscow emissaries: "to talk with foreigners about one's own land, what is happening now and

\footnotetext{
${ }^{3}$ The circumstances of his service remain unknown.
} 
what will happen, is treason against one's sovereign and the whole Commonwealth." ${ }^{4}$ However, Voropai did answer all the question of Muscovite emissaries and explained his action saying that it was not a treason to speak about peace among Christians (RGADA, f. 79, op. 1, d. 16 [1586], 432v.-440v.).

I quote these two cases in order to show that sometimes people responsible for obtaining information were not completely loyal to only one side, they could also be recruited by the enemy and start double dealing. Was this a common occurrence? There are not so many examples of such behavior mentioned in sources, but I would say that it was one of the ways for borderland people to survive. Most of people who had to live next to the border, either common people, peasants or townsmen, or nobles, were interested in peace with Muscovy.

Such big importance attached to the conditions in the borderland is also visible in letters of the Starosta of Orsha, Filon Kmita. In 1572, by order of some of the Lithuanian lords, he wrote a letter to Ivan IV, in which he offered assistance to his son Fedor in obtaining the Polish-Lithuanian throne. As we now know, this was only a trick devised to deflect the Tsar's attention, prevent the Muscovite military attack, and uncover the further plans of Ivan IV (Lulewicz 2002, 144). Later, the Starosta of Orsha narrowly avoided allegations of treason, but he was relentlessly confident about the correctness of his actions: in the uncertain conditions of the borderland, he wrote, people felt danger from both the Lithuanian and the

\footnotetext{
${ }^{4}$ In this case, "the Commonwealth [Rzeczpospolita]" is used in the meaning of the whole nobility of the Polish-Lithuanian Commonwealth.
} 
Muscovite side, and should defend themselves in all possible ways (Przezdziecki and Malinowski 1844, 271). Many of his letters paint the image of the borderland as a dangerous space, open to enemy's invasions, always in a state of alert.

From this brief review we can conclude that during the Livonian War the described territory still preserved some borderland features, the main among them being the capability to maintain a dialogue. This territory, which for a long time was the subject of struggles and wars between two states - Muscovy and the Grand Duchy of Lithuania - created a specific type of identity, a local identity less connected to the Center, one that prevailed both on the Lithuanian side and among old settlers 152 of Smolensk Land.

As we can see, the Borderland with its specific conditions became for its inhabitants their main experience: to the local people it constituted a certain "imagined space," which dominated their everyday lives, determined their choices in a time of conflict, and made them constantly watchful and interested in peaceful coexistence with the people across the border.

\section{REFERENCES}

Baliulis, Algirdas, ed. 1996. Lietuvos Metrika: Knyga Nr. 564 (1553-1567): Viešuju reikalu 7 knyga [Lithuanian Metrica: Book 564 (1553-1567): Book of public affairs 7]. Vilnius: Mokslo ir enciklopedijų leidykla.

Domańska, Ewa. 2011. "Historia antropologiczna: Mikrohistoria" [Anthropological history: Microhistory]. In Natalie Zemon-Davis, Powrót Martina Guerra, translated by Przemysław Szulgit, edited by Ewa Domańska, 195-234. Poznań: Zysk i S-ka. Dyplomatariusz gatęzi niesuchojeżskiej [Collected diplomatic documents of the Niesuchojeże line]. 1910. Vol. 7 of Archiwum Książą Lubartowiczów Sanguszków w Stawucie, part 2, 1554-1572. Lwów: Instytut Stauropigijski. 


\section{LIFE STRATEGIES IN A WARTIME BORDERLAND...}

Ianushkevich, Andrei. 2013. Livonskaia voina: Vil'no protiv Moskvy 1558-1570

[Livonian War: Vilnius versus Moscow 1558-1570]. Moskva: Kvadriga.

Karpov, Gennadii, ed. 1887. Pamiatniki diplomaticheskikh snoshenii Moskovskogo

Gosudarstva s Pol'sko-Litovskim [Documents of diplomatic relations between the Muscovite and Polish-Lithuanian states]. Vol. 59 of Sbornik Imperatorskogo Russkogo istoricheskogo obshchestva. Sankt-Peterburg: Tipografiia F. Elkonskogo i Ko.

Karpov, Gennadii, ed. 1892. Pamiatniki diplomaticheskikh snoshenii Moskovskogo Gosudarstva s Pol'sko-Litovskim [Documents of diplomatic relations between the Muscovite and Polish-Lithuanian states]. Vol. 71 of Sbornik Imperatorskogo Russkogo istoricheskogo obshchestva. Sankt-Peterburg: Tipografiia A. Kataiskogo i Ko.

Kenevich, Ian. 2011. "Obstoiatel'stva dialoga na pogranich'e: Nekotorye razmyshleniia" [Conditions of dialogue in the borderland: Some reflexions]. In Tsivilizatsionnyi vybor i pogranich'e, vol. 4 of Debaty IBI AL, edited by Ian Kenevich, 91-108. Warszawa: IBI AL.

Kieniewicz, Jan. 2005. "Borderland and Civilizational Encounter." Memoria y Civilización: Anuario de Historia 8: 21-49.

Krom, Mikhail. 2010. Mezh Rus'iu i Litvoi: Pogranichnye zemli v sisteme russkolitovskikh otnoshenii kontsa XV-pervoi treti XVI v. [Between Ruthenia and Lithuania: The borderlands in the system of Russian-Lithuanian relations from the late 15 th to the first third of the 16th century]. Moskva: Ob"edinennaia redaktsiia MVD Rossii.

Lulewicz, Henryk. 2002. Gniewów o unię ciag dalszy: Stosunki polsko-litewskie $w$ latach 1569-1588 [More ado about the Union: Polish-Lithuanian relations in 1569-1588]. Warszawa: Neriton.

Pogodin, Mikhail, and Dmitrii Dubenskii, eds. 1843. Kniga posol'skaia metriki Velikogo Kniazhestva Litovskogo, soderzhashchaia v sebe diplomaticheskie snosheniia Litvy v gosudarstvovanie korolia Stefana Batoriia [The ambassadors' book of the Lithuanian Metrica, covering diplomatic relations of Lithuania during the reign of King Stephen Bathory]. Moskva: Universitetskaia tipografiia.

Przezdziecki, Aleksander, and Mikołaj Malinowski, eds. 1844. Źrzódła do dziejów polskich [A Polish history sourcebook], vol. 2. Wilno.

RGADA [Russian State Archive of Ancient Documents, Moscow], f. 79, op. 1, d. 16, [stolbets] 1586-1587.

RGADA, f.79, op. 1, reestr 2, d. 1, [stolbets] 1579.

RGADA, f. 79, op. 1, reestr 2, d. 2, [stolbets] 1569.

Ścigaj, Paweł. 2012. Tożsamość narodowa: Zarys problematyki [National identity: An overview]. Kraków: Księgarnia Akademicka.

Temushev, Viktor. 2018. Russko-litovskoe pogranich'e: Gomel'skaia zemlia v kontse $X V$-pervoi polovine XVI v. [The Russian-Lithuanian borderland: The Homel Land from the late 15 th to the first half of the 16th century]. Moskva: Tsentrpoligraf. 


\section{Bato Dondukov}

ORCID 0000-0001-5501-9858

East Siberia State University of Technology and Management, Ulan-Ude

\section{VIRTUAL REALITY AS FIELDWORK: \\ A STUDY OF BUDDHIST \\ COMMUNITIES OF RUSSIA \\ ON THE INTERNET}

INTRODUCTION

There is probably no need anymore to demonstrate the fact that the Internet has penetrated into all spheres of life and that, conversely, it does not exist separately and detached from reality. A new question is whether the Internet is an equivalent to reality as a field in which to carry out research in cultural studies, anthropology, and other human sciences. How to look for phenomena on the Internet? How to understand what exactly occurs in this space and in what direction it moves? In this article I would like to describe my experience of studying Buddhism in the Russian-language segment of the Internet, which was not only a research experience, but also an insider experience for myself as a Buddhist and Internet user, and an experience of a shift in academic views. The Internet is a rather specific sphere in which to study religion due to various 


\section{Bato Dondukov}

features of sacrality, like those connected with the transfer of practice, which in Buddhism requires the physical presence of the teacher, and other aspects of religion that at times make its online manifestations more difficult but simultaneously add mysteriousness and awaken interest. The move of various religious processes into the Internet is a topic that is more than relevant today. Religion on the Internet becomes a more and more popular direction in the humanities; various aspects of it are, for example, studied in the Heidelberg Journal of Religions in the Internet. Nevertheless, case studies of Christianity and Islam clearly prevail in the journal over ones concerning Buddhism, not to mention the Buddhism of the Russian Internet.

156 Meanwhile, there is a fair amount of Buddhist resources on the Russian-language Internet, which can even be confusing at first: what to begin with, what to look for, and what research methods to apply? Taking into consideration the fact that there is almost no research devoted to the functioning of Buddhism on the Russian Internet, my experience can be called pioneering, which is why from the very beginning it took on the form of an exploration. Apart from issues concerning the Internet as a new field of research, I also share my thoughts about academic traditions, because my experience involved a switch in academic views and approaches from exact sciences to the humanities, and also from the Russian academic tradition to the European one. 
VIRTUAL REALITY AS FIELDWORK: A STUDY OF BUDDHIST...

\section{FIRST STEPS IN RESEARCH}

Before my graduate studies at the University of Warsaw, I studied Statistics and Accountancy, and worked as an IT specialist in the Republic of Buryatia, Russia. Looking back at the first year of studies in Poland, I can say that my IT background determined the first steps of my research. The Internet space, with no boundaries except for the linguistic ones, was full of various Russian-language Buddhist resources. As I had studied statistics, I decided to consider Internet as a database from which to draw big data for analysis. I started to look for software to work with such data and also thought about using statistical methods such as scaling factors, etc., which I expected to yield noteworthy results.

First of all, I applied search engines to identify the quantity of Buddhist resources on the Russian Internet. By using various combinations of Buddhist terms as the search string, I tried to classify the returned resources according to various criteria, like association with a certain variety of Buddhism. For instance, entering Buddhism in the Russian search engine Yandex yielded ca. 37,000 records, out of which 18,000 were associated with Tibetan Buddhism, 10,000 - with Southern Buddhism, and so on. In such a way, the results of initial exploratory work were represented by tables with statistical reporting. In other words, I tried to reveal the very existence of Buddhist resources, their quantity, as well as ratios and interrelations between their varieties. 
However, such approach quickly led me to a deadlock, for two main reasons. Firstly, I realized that while big data could reveal some regularities, working with big data could actually cause me to miss some important phenomena. Secondly, Buddhism had too many doctrinal and other peculiarities which complicated the usage of big data methods even more. In other words, research devoted to Buddhism was difficult due to the complexity of the existing categories. Many of them demanded reconsideration and deconstruction, or altogether new ones needed to be developed. One of the problems was that the content of the existing categories missed a lot of issues concerning identity and its expression. For example, the definitions of traditional Buddhist and neophyte are rather vague. Such ethnoses as Buryats, Kalmyks, and Tuvinians are usually referred to as traditional Buddhists of Russia. In Buryatia, Kalmykia, and Tuva, the traditional religious environment of Tibetan Buddhism has been developing over the last 400 years; and it has worked out specific features of perception of the sacred, as well as specific religious practices and rituals. In other regions of Russia, Buddhism started to develop much later, drawing from all possible branches and schools, and thus shaping other types of Buddhist identity. I will not go into details in this article, but the fact is quite obvious: nowadays a person, irrespective of his or her ethnic origin, can come into contact with different Buddhist environments and therefore the above-mentioned categories no longer reflect stable regularities. Big data analysis demands a rather rigid categorization, and such vague definitions can considerably distort the result. That is why it is more 
appropriate to consider each case separately. Thus, before I even started using big data software, I realized it was better to focus on other methods for my research.

After the disappointment with big data analysis's ability to give an adequate idea of the Buddhism on the Internet, I decided to approach the topic from a reverse perspective and to try to study the Internet activity of the most influential offline Buddhist organizations. I started to visit the webpages created by the official Buddhist communities, sanghas, of Russia, trying to comprehend the main purposes for Internet resources creation. To my discontent, I realized that Buddhist institutions paid little attention to the Internet space, and did not make active efforts to attract Internet audience. Looking through their webpages, I recognized that the majority of them had rather simple structure and generally contained information about the organization, the teacher, events, which made them look like Internet announcement boards. Some websites stored electronic Buddhist literature and other information; however, there were practically no attempts of interaction with people online, or of transferring sacral practices into the online space. A lot of webpages were created at the beginning of the 2000s and stayed unupdated for many years, or were simply abandoned. At that point, a crucial question arose about the reasons why the Buddhist organizations of Russia paid no interest to the Internet space. That issue would certainly be analyzed in my study, yet I did not consider it a possible basis for my project, as I found it pointless to build research on lack of activity. Buddhist institutions undoubtedly had a great influence on the processes happening offline; 


\section{Bato Dondukov}

however, their Internet activity was very low. At the same time, the Internet was rich in various Buddhist resources, and if they were not created by the official organizations, it was necessary to find out who they were created and directed by, and thus to understand who influenced the online Buddhist space. I could not answer these questions by means of either the first, or the second of my initial approaches.

\section{ACADEMIC MILIEU AND SWITCH IN APPROACHES TO SCIENTIFICITY}

My first steps in research supported my main belief about high value of objectivity and distance from the studied object. In other words, I was convinced that I needed to find information and then analyze it, without joining in or interacting with the phenomena found on the Internet. It is difficult to say what exactly influenced such belief: the fact that I had studied statistics or the Russian academic tradition in general, yet for me, it was something self-evident. I also think this attitude could have formed under the influence of specifically Buryat academia, remote and small in comparison to the central one, one which could only tentatively describe its findings using the methods provided by the center, and make a report about the studied object that would satisfy the center. I perceived such approach as being in line with the conditions of scientificity, whereas interference with the studied object and subjective experience I treated as unscientific. The big amount of data available on the Internet and the use of statistical methods met my perception of 
scientificity. At the same time, my background and my notions of scientificity created a certain barrier and for a long enough period prevented me from immersing into online Buddhist communities of the Russian Internet.

To my surprise, I later found out that I had been following the principles of positivistic sociology, such as reliability, representativeness, reactivity, and replicability (Burawoy 2009, 30-32). This approach underlined the importance of distance from the studied object and of standardized methods of data collection and analysis. The reason that I found this surprising was that, interestingly, I had not been acquainted with these principles and had never read any academic works about them. In other words, it seems that the need for positivism permeates the Russian academic milieu and it is not even necessary to expressly master its principles. This thirst for positivism is the natural and only choice for this model of scientificity. Professor Valerii Tishkov, in the introduction to his book Requiem for the Ethnos, describes exactly the same situation when he argues that postmodern ideas and hermeneutical approaches are criticized and not accepted by the Russian academic community, which negatively perceives and calls such approaches "Western influence" (Tishkov 2003, 9). In short, the Russian academic community is not ready to leave behind positivist approaches developed in Soviet times and before. To my mind, the Russian rejection of "Western influence" is rather natural because so-called "postmodern views" disrupt the existing academic structures, which inevitably provokes resistance. In my personal opinion, the acceptance of a postmodern framework in Russian science is a matter of time, 


\section{Bato Dondukov}

and a lot might, in fact, have changed in the 15 years that have passed from the publication of Tishkov's book to the time of writing these words. However, if we speak about the academic community in Buryatia, from my perspective, the situation is still the same. Recently, I took part in a seminar with the Buryat colleagues and raised the topic of immersion and interaction with the studied object, but was met with comments that such approach was just not scientific.

The studies at the University of Warsaw have exerted on me the very "Western influence" some Russian academics oppose, and my views on research approaches have significantly changed over time. First of all, my supervisor, Professor Ewa Łukaszyk, 162 influenced the shift in my academic views. Cooperation with her has helped me to understand what kind of approaches were appropriate and what kind of questions could be important to the Western academia. Secondly, the very academic milieu has impacted me. Many scholars with whom I was acquainted in Poland were performing fieldwork research. Communicating with them, I noticed that the experience in the field - for example, extraordinary cases which the researcher had witnessed or which happened directly to him or her in the field - raised great interest. If they spoke about statistics, their research would obviously not spark so much curiosity. I also realized that the image and understanding of the object came from its observation, and mostly from such cases which were registered by the researcher him- or herself. And while I could feel this approach was mostly a prerogative of the Western academia, which traditionally explored the outside world, the Orient, etc., 
I saw that such approach was much more inspiring. It may look as if I was adapting to the Western academic community in order to be accepted, but I felt as if I had been given a free hand and my own deliberations had led me to no longer consider the Internet simply as a database but as a field with which it was possible to interact, taking into account not only quantitative and qualitative indicators, but also personal experience.

\section{THE INTERNET AS THE FIELD}

Thus, I started to perceive the Internet as a field of anthropological research, where you met people with different ideas about Buddhism, who acted, interacted, and thus shaped the Buddhist Internet communities. My shift in approach to research can be compared to the shift from Web 1.0 to Web 2.0, where it is no longer the creators, but rather users of the resources, their self-expression and interaction, that are of greater importance (O'Reilly 2005). In 2013, I had the opportunity to accompany Dr. Albert Jawłowski during his fieldwork on Buddhism and Buddhists in Buryatia. The experience proved very useful for me, as it provided first-hand knowledge on how visiting researchers collect data and attain insight of the people inhabiting a space. Observing Albert and people whom he talked to, I understood that when doing research, it is important not only to search for and record interesting cases and data from informants but also to reflect in order to interpret these data. And this reflection can be gained through long stay within the studied community. 
Studies in Poland and the new academic environment gave me an idea: why not treat the Internet as a place, a field which I can go to for a long time, get acquainted with people I meet there and visit the Buddhist Internet communities?

At this point it is necessary to say a few words about the Internet users who shape Buddhist communities online. In 2014, during one of the seminars, I presented a small overview of my research, and was asked a question very crucial from the point of view of anthropology: "How can you be confident that the user you study represents him- or herself truly on the Internet and is not fake?" This is a rather typical question for people who do not actively use the Internet. In general, the concept of virtuality often misleads to the idea that Internet communities are less real than physical ones (Jones 1995). Nevertheless, this question made me think about what exactly the contemporary Internet user was like. From the very beginning of the online space, the possibilities for self-representation of individuals on the Internet were evolving, starting from a nickname in local chats to global social networks such as Facebook, where a user is required to provide real information about him- or herself. In other words, user representation has been shifting from anonymity to de-anonymization. The once popular phenomenon of Internet freedom of self-representation is no longer relevant in the conditions of social networks. Due to the fact that for an anthropological research the question of identification of the studied people is particularly important, I decided to focus on social networks instead of ordinary webpages. The very essence of social networks is to recreate real social 
communication on the Internet, a goal which cannot be reached in the conditions of anonymity (Tikhonov 2013, 17). Of course you can create a fake account on a social network specifying another sex, age, nationality, etc., yet making this account look real requires much effort of painstakingly imitating rich social bonds of this nonexistent persona.

In 2015, I observed a popular video games portal organize a giveaway where people who reposted an announcement in the social network VKontakte could win a gaming computer worth $\$ 10,000$ or one of 49 other prizes. The promotion gained such popularity that about five million users were following the online draw, which even caused a temporary crash of the social network's servers (Shchepilov 2015). The winner was picked by means of a random selection service. The organizers of this promotion were afraid that a great number of users had created fake accounts to increase their chances for victory, therefore they approached this issue carefully. When the service chose a user, they looked at the photos, friends and relatives in his or her account to judge its completeness, and if there were very few data and it was evident that the account had been created quite recently, they excluded the user from the giveaway.

I started to approach the users in the same selective manner before including them in my research. This is important since it is necessary to understand the user's background as a representative of a certain Buddhist community and belonging to a certain group can influence his or her views and behavioral motives. For example, an ethnic belonging (Kalmyk, Buryat, 


\section{Bato Dondukov}

Tuvinian, or Russian) can speak about belonging to traditional or non-traditional Buddhism communities, just as membership in communities of Ole Nydahl or Theravada communities can be very telling. What is more, studying the actions of a specific representative gives an idea about community in general, and this cannot be achieved in the conditions of anonymity.

\section{LONGTIME IMMERSION INTO \\ INTERNET COMMUNITY}

In comparison with offline fieldwork, longtime immersion into Internet communities is of even more crucial importance. When offline, direct acquaintance with people facilitates openness and dialogue. There is also an opportunity to get easier access to the community thanks to the people from inside: a person more willingly cooperates and agrees to help with research if he or she is asked by someone he or she knows. I think field researchers will agree that having a friend inside the community is an invaluable help in accessing it and starting interaction with its members. On the Internet, people often interact online while being absolute strangers to each other. A researcher is another stranger to them, so they can easily avoid communicating with, or just ignore, him or her. Neither nonverbal means of communication nor human qualities help you to access the online field. Administrators of public pages on social networks may receive hundreds of questions a day, and due to such busyness, can only answer your queries about research briefly and casually. Longtime immersion and 
participation in discussions online, on the other hand, allows one to build relationship with the users and to obtain the status of a familiar person, which helps to build closer contact and engage in deeper conversations.

Another important feature of online fieldwork which speaks in favor of longtime immersion is that events on social networks are quickly changing, as are the users, who come and leave (apart from moderators and administrators, who permanently follow the activities of their public pages). Long presence in the online communities helps to identify some regularities or stable phenomena which are formed by both permanent and temporary participants. A lot of curious cases happen on social networks. They may cast a shadow on, or damage, the reputation of the Buddhist community, or simply distort the Buddhist doctrine, so after publication such materials are often removed by administrators. That is why long and frequent presence on a public page allows you to record the events and reactions of users, and thus to get an idea about the community and its members.

In addition, while the sequence of events can be easily traced in archives and databases, continuous observation allows you to feel the interrelations, online and otherwise, of phenomena arising online. For instance, I could feel a strong tie between the incident of desecration of a statue of Buddha by a Dagestanian in Kalmykia which occurred in April 2016, and the protest wave against "Buddha Bars" in Russia in July 2016. In both cases disapproval was mainly related to the national question of traditional Buddhists. If it were not for longtime immersion in both the studied communities and Buddhist affairs, I could have 


\section{Bato Dondukov}

missed this interconnection, as no protest posts about Buddha bars had references to the first event.

In such a way, I started my immersion into the Buddhist Internet community, and the quantitative data I'd gathered before became very useful, as they led me to the most popular public pages. Following the activities in several Buddhist online groups of VKontakte, I decided to focus mainly on the community called "Buddizm," which at that time had 27,000 followers and could be estimated as the most popular not only by the number of users but also by the number of discussions and user actions.

The shift from an observer to a participant could be reached only in interaction with other users. And here my another 168 background - not of a researcher, but of a Buddhist - came to the forefront. What is more, I can identify myself not just as Buddhist, but as a traditional Buddhist. Being Buryat, I was raised in a Buddhist tradition, though it should be noted that my family was not quite typical. When I was a child, my parents often took me to various Buddhist events and retreats, we met different Buddhists, including visitors from other cities in Russia and abroad. In other words, by the time I started my research, I had already had some experience of communicating with Buddhists, as well as some knowledge of Buddhist philosophy. If I had only superficial knowledge about Buddhism, it would be difficult to obtain some position in the online community, and most likely I would join the visitors who ask such elementary Buddhist questions as "What does Buddhism teach?," or "How to convert to Buddhism?" At the same time, my traditional Buddhist experience practically deprived me of 
a neutral point of view regarding this environment. I cannot say I had a "clear" view on the phenomena occurring in the online Buddhist groups, but despite such "obstacles" to my objectivity, I think that my traditional Buddhist background gave me advantages in searching for cases to study which could be inaccessible to outsider observers. In other words, I was an insider of the Buddhist community, who started to participate in online Buddhist interaction.

On the "Buddizm" public page, I started to ask questions and express my opinion commenting the questions of newcoming users. To my surprise, it turned out that among those who asked and answered questions in this group, there were only three traditional Buddhists: one Buryat (me), one Kalmyk, and one Tuvinian, and they were not frequent participants in the discussions. I also noticed that advice from traditional Buddhists was often corrected by "old citizens" of this resource. Their words could be met with such comments as: "the decline of Buddhism in your region is possible to overcome by..." or recommendations like: "you need to study the theory more." In other words, in the Internet space, the western Buddhists a priori assumed more authority than traditional Buddhists. It turned out that this space was not so natural for me as a Buryat Buddhist and I could not feel an insider in that environment. I had the feeling of being viewed as a younger brother of more advanced western Buddhists. For me, it was rather strange because in Russia traditional Buddhists significantly outnumber the Western ones. In such a way, I defined one of the peculiarities of the online Buddhist community: the amount of traditional Buddhists was 


\section{Bato Dondukov}

much smaller than that of non-traditional ones, which was exactly opposite to the offline situation. I needed to observe this phenomenon for a longer time in order to trace the appearance and activities of traditional Buddhists in this group, and try to understand the reasons for such low interest in their opinions, and thus, their low influence on Internet Buddhism.

Soon, I discovered another aspect of this group that surprised me: this community was neutral and did not belong to any Buddhist school, and thus, was full of disputes around the asked questions. Buddhism, which has the reputation of the world's peaceful religion, in this case of the "Buddizm" public page in VKontakte was an arena of constant fight over the truth 170 of views. The fact that people often asked questions on this resource was transforming the interrelations into market ones: representatives of various communities tried to establish their own views and convert followers to their school of Buddhism. Users went as far as to criticize Buddhist teachers who did not fit their views, which I as a traditional Buddhist was bewildered with. When you grow in a traditional Buddhist environment, you hold the monks in great respect. In Tibetan Buddhism, to criticize teachers means to behave badly and bring bad karma. Since early childhood, you observe respectful attitude to monks from any group of society and thus the criticizing of teachers causes great dissonance. For example, you can meet such cases in the Internet when one traditional Buddhist in a conversation referred to a source he revered - the texts by Bidiya Dandaron, the Buryat Buddhist guru of the Soviet period - and received such answer: "Dandaron's ideas are complete nonsense even for 
Vajrayana." Of course such expressions caused further indignation and argument. Possibly, this freedom of expression is the reason why a great number of traditional Buddhists avoid these public pages. For me as a researcher, the interest in such cases prevailed over rejection of them, though I cannot say I did not feel the same indignation. By and large, such constant disputes over the views on Buddhism have made this community one of the most popular ones and caused it to stand out significantly from the other Buddhist public pages in VKontakte.

\section{TOOLS FOR ONLINE RAPPORT \\ AND IMMERSION}

Apart from active participation in discussions, social networks provide other tools, which allow for a passive response that helps settle the dispute and build rapport with the community. One such way to take the side of a person is by leaving a like on his or her statement. Comments with most likes gain more value both for the participants of discussion and for observers. The authority of a user within the social network grows if he or she often participates in discussions and receives likes from the majority. Furthermore, a like from such person starts to weigh more than likes from other users. At the same time, users usually track who supports them via likes, and generally start to perceive those people as allies. In other words, such passive participation in disputes promotes rapprochement with active users. This is not to say that I used these tools for rapport opportunistically. I actually left likes only on those comments 
with which I agreed. I noticed myself that after I liked a user's opinion, his or her attitudes towards me changed for the better over time. The users whose commentaries I had supported started to support me in return, or if they did not agree, they expressed it more delicately.

Now that I look back at my Internet fieldwork, I see that my position of a researcher allowed me to look more closely at actions and reactions of users and try to discover their motives, without perceiving them as absolutely positive or negative. I did not join any specific group of users, but tried to stick to a neutral position. Over time, I started to realize that the majority of conflicts happened because of misunderstanding of 172 the positions of the opposing groups. For example, the followers of Theravada were offended when the Tibetan Buddhists applied the term Hinayana (from Sanskrit: "Lesser Vehicle") to refer to Southern Buddhism. However, the Tibetan Buddhists simply might not have known it was offensive because the categories of Mahayana ("Great Vehicle") and Hinayana come from sacred texts, such as Lamrim, and were often used by the teachers of Tibetan Buddhism. Yet representatives of Theravada could perceive this as an intended insult. In turn, Theravada followers could speak depreciatingly about the power of deities and bodhisattvas of Tibetan Buddhism, because they do not exist in the Southern tradition, and the representatives of Tibetan Buddhism who did not know about the absence of a pantheon of deities in Theravada could become offended, too. When I became recognizable among frequent users of the "Buddizm" public page and I started to present myself as a scholar who 
researched this community, at least in personal correspondence with the participants of this group, users behaved more openly and tried to clarify their positions in more detail. I also continued to take part in discussions, and in cases of conflict I tried to settle the dispute by explaining to the parties the reasons behind one or another position. For example, in the discussions concerning traditional Buddhism, I tried to explain its features which were unknown to western Buddhists. Surprisingly, I often settled the disputes, and even received a peacekeeper reputation. Thus, my position as well as relations with users strengthened in this online community, and allowed me to maintain an open dialogue.

"THE GREAT SPLIT,"1 OR HOW I BECAME AN ADMINISTRATOR OF THE "BUDDIZM" PUBLIC PAGE

The "Buddizm" public page in VKontakte, which positioned itself as neutral, had a number of administrators, from both Theravada and Mahayana branches of Buddhism. There were, however, no representatives of the traditional Buddhism of Russia (Buryatia, Kalmykia, or Tuva). In 2015, there developed a conflict between administrators. It turned out difficult to uphold the neutral environment because of irreconcilable differences in views on Buddhism and some personal reasons. The group actually split and representatives of Theravada created their

\footnotetext{
${ }^{1}$ The name "The Great Split" was coined by one of the participants in the conflict.
} 


\section{Bato Dondukov}

own "neutral" public page. The number of the "Buddizm" administrators thus decreased rapidly, and unexpectedly for myself, I was invited to become one of the administrators of this resource. As the remaining administrators argued, I was a person with neutral position and as such I suited them. I became even more surprised when I was invited to administrate the new "neutral" group created by representatives of Theravada, as well. I accepted all the invitations and thus to some extent formed a new case to study because I became the first and only representative of traditional Buddhists among the administrators of both groups.

The fact that I was an administrator started to matter to other traditional Buddhists. I received messages from several Kalmyks and a Tuvinian with requests to settle a debate or remove content which, for example, showed in bad light the Buddhism of Kalmykia. In other words, they perceived me as "their" person who had some position and could understand their problems. There was even a situation when a Tuvinian asked me to enter a discussion about the Buddhism of Tuva on another public page and to express my opinion as a weightier one, because I was one of administrators of a large resource.

In such a way, I became a real insider researcher, who was not only Buddhist but also a full member of an online Buddhist community. The status of administrator also gave me access to another resource, a closed page for administrators, which I had not been aware of. In this space, called "staff area," administrators discussed how to settle various cases, which users to ban, and how to justify the restrictive actions. Incidentally, the 
conflict which led to the split of administrators took place on this internal public page. For reasons of ethics, I will of course not disclose, in my dissertation or elsewhere, what occurred in this "staff area." However, this new status of a user with privileges, additional opportunities such as editing content, banning users, and having access to an internal service, became a completely new experience. Being an administrator allowed me to understand and interpret more deeply the way this Internet community functioned as well as the mission and responsibility it took upon itself as a Buddhist resource which actually did not have any relations to the Buddhist institutions and organizations offline.

\section{CONCLUSION}

The online Buddhist communities today have influence comparable to that of the official Buddhist institutions; and especially in a situation when the latter conduct little activity in the Internet space, it is very important to study the other, new Buddhist communities. My academic way of studying the Buddhist communities of Russia on the Internet developed from exact sciences to the humanities, and also led to a shift from a Russian positivistic scientificity to a Western relativism. In this article, I described the methods I used during my Internet fieldwork, including longtime immersion into the Internet community, and tools of rapport, such as participation in discussions and leaving likes, which helped me to understand more deeply the issues of the online Buddhist community of Russia and 
even led me to the position of an administrator of two popular Buddhist public pages on the VKontakte social network. In some periods I thought that my methods of data collection were too involved, but overall I am convinced that any other way of achieving high-quality contact with the online community and getting an idea about the processes happening there would be more difficult and would not possibly bring me to the level of awareness that I managed to reach. In my opinion, nowadays it is more relevant to perceive the Internet space not as a database but as a field similar to a physical territory. And I hope that my experience of Internet fieldwork and of an insider of the Internet community proves helpful not only to Buddhologists, but to all researchers of the Internet.

\section{REFERENCES}

Burawoy, Michael. 2009. The Extended Case Method: Four Countries, Four Decades, Four Great Transformations, and One Theoretical Tradition. Berkeley: University of California Press.

Jones, Steve. 1995. "Understanding Community in the Information Age." In CyberSociety: Computer-Mediated Communication and Community, edited by Steve Jones, 10-35. Thousand Oaks: Sage.

O'Reilly, Tim. 2005. "What is Web 2.0." O'Reilly Media website, September 30. Accessed July 1, 2018. http://www.oreillynet.com/pub/a/oreilly/tim/ news/2005/09/30/what-is-web-20.html

Shchepilov, Aleksandr. 2015. "Administratsiia soobshchestva pozhalovalas' na blokirovku iz-za nepoladok 'VKontakte,' vyzvannykh eio konkursom.” TJournal website, April 9. Accessed July 1, 2018. https://tjournal.ru/54678-igm-vs-vk

Tikhonov, Oleg. 2013. Transformatsiia fenomena identichnosti $v$ prostranstve seti Internet [Transformation of the phenomenon of identity in the space of the Internet] ( $\mathrm{PhD}$ thesis). Kazan': Kazanskii (Privolzhskii) federal'nyi universitet.

Tishkov, Valerii. 2003. Rekviem po etnosu: Issledovaniia po social'no-kul'turnoi antropologii [Requiem for the ethnos: Studies in socio-cultural anthropology]. Moskva: Nauka. 


\section{III}

\section{FROM PERSONAL IDENTITY TO IDENTITY OF A SCHOLAR}




\section{Kyunney Takasaeva (Künnej Takaahaj) ORCID 0000-0002-1383-9206 \\ University of Warsaw}

\section{REFLECTIONS ON NAME AND IDENTITY: "WHAT DO YOU SEE IN MY NAME?"}

\section{INTRODUCTION}

French writer of Lebanese descent Amin Maalouf in his book In the Name of Identity: Violence and the Need to Belong (Maalouf 2003) states that each person has many identities and that struggling to harmonize these multiple identities and narrowing them to just one is a source of problems and conflicts. The author claims that the social adaptability of an individual with multiple identities places them in a borderland space and gives them the privilege of being a connecting link between cultures, countries, languages, etc. The issues of pluralism posed twenty years ago by Amin Maalouf are even more urgent today, when we search for identification in the globalizing world, than they were at the end of the 1990s.

In the context of this article, I am interested in the author's theses on components of identity: vertical (given from birth) and horizontal (obtained in the process of socialization), and the 
need to develop them not in isolation, at the expense of each other, but seeking harmony between them. Otherwise, conflicts arise, which causes the problems to worsen and eventually may lead even to wars. According to the author, identity becomes a problem when it is threatened. He connects this with the fact that the social environment forces a person to affirm a particular identity - often religious, racial, or ethnic - to make it his "banner" and pride, which reduces identity to one single dominant affiliation and pushes people into narrow partisanship, sectarianism, intolerance: if we don't want the world to become a jungle, warns Maalouf, we need to observe, study calmly, understand the dual nature of this phenomenon and above all the fact that many crimes in the modern world are committed on behalf of or in the name of acquiring or maintaining identity. Amin Maalouf thus tries to express the contradictory essence of identity based on the need to belong and the need of each person to protect what they feel to be their innermost self. This need can provoke a person to both aggressive and peace-loving actions with the aim of self-preservation and protecting their identity, especially in the fight against the destructive impact of globalization.

The author examines himself, and his own life experience of a Frenchman of Libyan origin serves him as a guiding star in seeking a balanced awareness of the essence of his indivisible identity. In the works of Maalouf the reader discovers a Mediterranean culture which appears as a symbolic borderland space of tolerance, where different nations peacefully coexist. He is not a supporter of the concept of a clash, or conflict, of civilizations; rather, he speaks of a meeting of civilizations. 
He explains the uniqueness of his identity by the fact that he happened to live in two states, speak three languages, follow several cultural traditions. And all this cultural diversity has formed his single identity, from which nothing can be removed without damaging its integrity.

In this article, I would like to make a similar analysis. I want to consider the history of my identities, which have undergone a number of transformations due to my experience of living in different places and belonging to different cultures. I shall attempt an analysis of the transforming identity using the example of my own name and try to show the vertical and horizontal components of my identity in the life-long process of socialization. I would like to consider the dynamic that can exist between one's own name and one's identity as an individual and/or representative of a particular group/groups. For this kind of analysis, I have decided to share experiences of my native Yakut (Sakha) culture, or, more precisely, the experiences connected with my own microhistory of the name, which in my opinion reflects historical transformations/dynamics of identity-searching of the Sakha people.

\section{NAMING TRADITIONS IN THE HISTORY OF THE SAKHA PEOPLE}

Identity in the context of name transformation was considered by British linguist of German origin W. F. H. Nicolaisen in his article "An Onomastic Autobiography, or In the Beginning Was the Name." The author talks about the formation of his 
anthroponymic identity, thus initiating onomastic biography as a separate direction in autobiographical literature. He describes how his official name has transformed in the course of his life. Recorded in the birth certificate as Wilhelm Fritz Hermann, it initially reflected the family tradition as part of a particular genealogical culture, as well as, more generally, the belonging to the German national culture. Both these identifications changed with age and with changes in the author's socio-cultural environment, thus creating a separate, purely individual history of his own unique identity reflected in his changing name. Based on the above-mentioned material, I would like to offer a similar discussion of my own name.

The formation and development of the system of Yakut personal names has gone a long way, from compound names rooted in the Turkic naming tradition to the status of secondary names or nicknames, to the present-day revival. The three-component naming model among today's Yakuts was imported from the Russian culture after Yakutia's accession to the Russian state. Before the arrival of the Russians, the Yakuts did not need to use their patronymic names and surnames; these innovations were connected with official clerical work during the process of Christianization in Yakutia as well as the procedural needs of the state apparatus (population census, taxation, etc.). This process was gradual; it began in the first half of the 17 th century and was completed by the 1920 s.

The modern anthroponomic systems of Turkic peoples (a collection of ethno-linguistic groups to which the Yakuts belong) preserve the proto-Turkic model of the pre-Islamic and 
pre-Christian time. The study of Yakut personal names more specifically is inextricably linked with the history of the Yakut language. Historian Fedot G. Safronov raised questions about the Yakut ethnos's interactions with other nations in the process of its formation and historical development. According to him, in the anthroponymic vocabulary of the Yakuts, about $47 \%$ of etymologized names are Turkic words, $37 \%$ are Mongolian, 5\% - Turkic-Mongolian, 10\% - Evenki. This corresponds to the lexical composition of the Yakut language, which is basically Turkic, but has absorbed elements from the Mongolian and Tungus language groups (Safronov 1985, 23). Regarding anthroponymic Mongolisms, referring to the works of Leonid N. Kharitonov, Safronov admits the possibility of the emergence of early Mongolisms in the language of the ancient Turks before the formation of modern Turkic languages, including Yakut (Safronov 1985, 25). These borrowings could have appeared in those distant times when the Kurykans, the ancestors of the Yakuts, had close ties with Otuz Tatars, and then, having moved north to the territory of modern Buryatia, with the Mongols of the Onon and Kherulen River basins. The history of the formation of Yakut-Evenki contacts, Safronov claims, also comprised two stages: the first contacts took place during the time of the Evenks' cohabitation with the Kurykans in the areas of Lake Baikal and the headwaters of the Lena; the second stage began in the 10th-11th centuries, when the Evenks and Yakuts were again in geographical neighborhood on the territory of modern Yakutia (Safronov 1985, 26-27). Tungus-Manchurian dialect borrowings are represented mainly 
in names derived from elements of the landscape (Siibikte, Chagda), as well as in names associated with the military lexicon (Khotokhoon).

Yakut names were given at birth, but could be changed later in life, according to the character of the person. 17th and 18th century documents abound in pre-Christian names. After this period, due to Christianization, well-known Russian names spread among the Turkic Siberian peoples (the Chuvash, Yakut, Gagauz, Altai, Khakas). A Russian name was given to each Christianized Yakut at baptism. After that, the old Yakut names continued to be used along Russian ones. In the process of Christianization, however, the original given names of the 184 Yakuts, Evenks, Evens and Yukagirs were eventually almost completely replaced by Russian personal names. In this regard, it should be noted that Yakuts perceived Christianization as a peculiar naming process, which was also manifested in the Yakut vocabulary: Christianization is referred to as aat kiriite, or a process of receiving names. In Yakutia, one can still find so-called confessional (Old Russian, Old Believer) Christian names, such as Nikon, Avvakum, Theodosius (Feodosii), Bartholomew (Barfolomei), Illarion, Avksentii, Agrippina, Matriona, Theodor (Fiodor), and so on.

Historical periods can be traced by personal names in Yakutia. The process of Christianization (Russification) and then the onset of the Soviet period both marked the onset of a separate naming tradition. After the collapse of the Soviet Union, one can trace the process of returning to Yakut names. Modern Yakut scholars have been studying genealogy and 
naming traditions, and very fruitfully so; the Research Institute of Genealogy and Ethnology of the Peoples of the North of the Republic of Sakha (Yakutia) was created that organizes conferences and seminars on drawing up genealogies (also in digital form), an activity recently enjoying great popularity in Yakutia. Currently, the Yakut epic names and toponymy are the most thoroughly studied sections of onomastics. This finds its reflection in the name of the Republic. The lands of the Sakha (Sakha Sire) were called "Yakutia" during the Cossack campaigns and recorded in this form in archival documents. In the 1990s, the Republic officially regained the original name Sakha, but the name Yakutia remained in brackets. I will try to explain these onomastic processes in the present article, showing in parallel not only the dynamics of my own name but also the history of name and identity transformations in Yakutia.

\section{MY STORY IN MY PEOPLE'S HISTORY}

In comparison to the Buryats or the Türks (Turkic peoples) of Central Asia, among the Yakuts, Russian surnames and names are more common. In our family, the awareness that name and identity are associated was connected with the fact that my parents spent their student years in the 1960s far away from Yakutia, in Leningrad. My parents, father Takasaev Revolii Timofeevich (1942-2006) and mother Krivoshapkina Elizaveta Denisovna (1940-2001), were very proud that their studies passed in one of the most beautiful cities in the world, Leningrad, now Petersburg, during the Thaw of the 1960s. 
Being far from their native Yakutia, they felt the importance of identification through an ethnic name. They said that many nationalities (Kazakhs, Uzbeks, Buryats, Mongols, Koreans) could be identified by their names, and they were often asked why they, the Yakuts, had Russian names instead. Therefore, their circle of students from Yakutia decided to invent Yakut names for themselves - pseudonyms derived from Yakut literature and the Yakut epic (Olonkho), and it was then that my parents decided to give their future children only Yakut names.

My father told me why he and my mother decided to give us all, their three daughters, Yakut names - Sargy, Tuiaara, Künnei. He explained how unique my name was and how 186 hard it was for him to give it to me. He defended every Yakut name for his daughters when applying for birth certificate in the Yakut village council. This shows how determined he was in the choice of our Yakut names. Every time after one of us was born, my father visited the Yakut village council and had to insist that the Yakut names should be officially recorded. This was not practiced at that time due to the absence of such names in the official list of names in the Soviet era and the spread of Russian names, or Soviet names like Traktorina, Oktiabrina, etc. Therefore, many Yakuts only called children by their Yakut names at home, and officially everyone had mostly Russian names, surnames and patronymic names.

Thus, according to the law, at birth I was given a threecomponent name: Takasaeva Kyunneyi Revol'evna: the first is the paternal last name, the second is my name and the third is the patronymic (derived from father's name, and used in Russia in 
official situations). This is the form in which it was recorded in the birth certificate by the Yakut village council. The fact that my name was recorded during the Soviet period additionally caused certain problems with the usage of Yakut letters. As I said, there was no such name on the list of names in the Soviet period, just like there were no other Yakut names there. But my father insisted, as he already had two previous experiences with recording Yakut names for my older sisters Sargy and Tuiaara. Their names also demanded to be written in Russian transcription, which did not quite agree with the original Yakut pronunciation. For example, the elder sister with the original Yakut name Саргы (Sargy), which translates as "happiness, luck, success," in 1966 was recorded as Саргылана (Sargylana, Russified version, with the addition of the name Lana), and the middle sister with the Yakut name Туйаapa (Tuiaara), meaning "to sing, to float," in 1969 was registered as Туяра (Tuiara), due to the lack of double letters in Russian for those present in the Yakut alphabet to denote stress. The letters ЙAA (iaa) were therefore replaced by the Russian letter $Я$ (ia), which does not convey the original stress from the Yakut language. As for me, my Yakut name Күннэй (Künney) was written with the letters $Ю$ (iu instead of $\ddot{\mathrm{u}}$ ) and $Я$ (ia instead of e), that is as Кюнняй (Kiunniai), which completely distorted the original Yakut pronunciation of the name.

My name firmly connects me with my family, culture, and the history of the people of Sakha (Yakutia). I doubt, however, that when I was born my parents could have imagined that I would live for a long time outside my native republic and even 
abroad (in Poland) and that I would decide to call myself by my real original Yakut name: Künnei Takaahai (Künnej Takaahaj in Polish transcription). During my socialization and stays in different countries and different cultures, there have been cases of my name being distorted because my original name contains the spelling of the Yakut language - the letter $\ddot{U}$ in the given name (Künnei) and the double AA with the Yakut letter $h$ in the original spelling of my last name (Такааһай / Takaahai). Apart from orthography, this is also a matter of the semantics and phonetics of the name. As a result, each time, depending on the situation, I had to think of ways to quickly explain the meaning and sound of my name so that it could be pronounced correctly. If the situation did not require long communication, I tried not to pay attention when my name was pronounced incorrectly; in interaction with the broadly understood state, however, I am always on the alert for incorrect renderings of my Yakut name, since mistakes in pronunciation and spelling happen very often and can have greater consequences. Throughout my life, there have been situations when I was called by names completely unfamiliar to my close relatives - Esmeralda, Küna, Katia, Tat'iana Ivanovna, Kasia, Słońce i Księżyc, SunMoon, which I will try to explain further below.

When I was a child, Yakut names were not popular. In my rural Yakut childhood, at age 6, after reading fairy tales and watching films and cartoons with European faces and names (there were no other options), I wanted to have a "princess name." I liked the mysterious name Esmeralda - in my child imagination, it was precisely the name for princesses. Ironically, 
Esmeralda would not be a very strange name in the Yakut reality of that time. My aunt on the mother's side, Isabella, who had a musical talent and what they call romantic imagination, gave all her four children names beginning with the letter EEleonora, Eduard, El'sa and Edgard. With such names they had no particular problems in the then Yakut reality, in contrast to me, a girl with a proper Yakut name. My cousin on the father's side officially had a Russian name, Iraida Pavlova, and at home everyone called her by the Yakut name Künnei, but as she grew older, her Yakut name disappeared from use. Apparently, the presence of such extravagant names among my close relatives motivated my desire to be called Esmeralda, but ultimately only my favorite blue-eyed dolls, whom I imagined to symbolize me in my games, received this name.

Another telling event from my childhood was when we went to visit my mother's relatives in another region of Yakutia. I was outraged by the fact that a calf had the same name as me (Künnei). Later, it was explained to me that Yakuts from other areas retained the presence of Yakut names by giving them to pets, since Yakut names did not exist in the Soviet official lists of names. Such practices - adapting Russian names, naming domestic animals by Yakut names - were an indicator of historical transformation and an attempt to preserve the originality of Yakut proper names and ethnic identity in general.

Then, when I was about 10 years old, my whole family moved from the village to the Russian-speaking capital, Yakutsk, where I first encountered a multinational environment. In the street and in school, the children did not have Yakut names and they would 
often ask me what Russian name I had or try to transform my name to make it more convenient to use for Russian speakers for example, Küna or even Katia, based on the first letter of my name - but I did not like it at all. Later, when I was a student in Irkutsk, during the compulsory teaching internship in a kindergarten, my supervisor firmly stated that I should take a "usual," "pure" Russian name because it would be difficult for the kids to pronounce my unusual true name. I agreed to take the name of the teacher who demanded that I change my name, and thus I got the stereotypical "teacher's" name in Russia - Tat'iana Ivanovna. Although it was a very short period of time, I clearly remember that this experience did not agree with me and since 190 then I decided never to change my name to please society.

I began thinking of ways to explain my name to others so that they could memorize it. When making an acquaintance, I would spend much time explaining my name, what culture it came from, what it meant and why I did not agree for it to be Russified. This proved effective. Thus, when I worked as a university teacher in Moscow, where all my students were Russian, on the very first day I wrote down my name on the blackboard, asked the students to pronounce it correctly, and explained why I was doing this. Once there was even an incident at the department where I worked: the students did not remember the "usual" Russian names of the other teachers but they remembered my name exactly and even said that it was easy, because if one got used to it once, one never forgot it.

It was also during my Moscow period when my patronymic name Revol'evna became more used because name and 
patronymic is the official form of address in Russia, especially at universities. The Soviet-inspired name of my father was more understandable and acceptable for others than my Yakut name, which seemed complex and incomprehensible to Russian speakers. The name Revo, Revolii requires additional clarification. My father was named after the historic event that was the October Revolution of 1917. This reflects how strong both the belief in the Revolution and also the popularity of Soviet names were in Yakutia. One can only imagine the significance that the revolution (and revolution propaganda) had for the Yakut people. This must have applied in particular to my grandfather, since before leaving to fight in World War II (from which he never returned), he gave such name to his unborn child. He told my grandmother, "If it's a son, call him Revo, and if it's a girl - Liutsiia." That is to say: revoliutsiia (revolution), a name referring to the tradition of revolutionary Soviet names.

After my move from Russia to Poland and in connection with the spread of the Internet and social networks, I needed to come up with a new version of my name and an online nickname, and once again my name required a certain transformation. I decided to use as my online name my real name in its correct Polish spelling - Künnej Takaahaj. I was absolutely delighted with this opportunity. In addition, I noticed that when using the Latin alphabet, it became easier for me to explain precisely the Yakut pronunciation of my name. At the same time, it is precisely abroad that I have faced another problem, this time regarding the Russian spelling of my name, because I began to use my passport more often, and there my name is mechanically 
transliterated from Russian transcription to the Latin script using the official transliteration ("Kyunney Takasaeva"), which in my opinion completely distorts my Yakut name and has too many letters. I cannot get used to this form, and every time I fill official papers, I have to check how my name is spelled in my passport - I think it often seems suspicious to some officials.

There have been cases in Poland when people had trouble hearing or pronouncing my Yakut name properly so instead they called me by another name starting with a $\mathrm{K}$, for example, Kasia. Mostly they were people who were aware that they would not get to communicate with me for a longer period. In other 192 cases, after I explained the meaning of my name, people would prefer to use its literal Polish translation and call me Słońce i Księżyc (Sun and Moon). I also noticed that after I began to introduce myself to foreigners as Künnej Takaahaj, they sometimes address me in the masculine form in correspondence, which makes me smile. The name does not underline gender identity, which in fact appeals to me, and consequently does not betray my gender until one sees me personally, excluding only people belonging to the Yakut culture.

The recent years have seen a new transformation of my name in international communication: more and more often I come across situations that require the use of an English spelling of my name, and not its Polish transcription. In other words, the process of globalization and the associated proliferation of English now obliges you to think about how to correctly sign your messages. I do need to think about the best way to spell 
my name in English, since the Polish name does not correspond to the English transcription and is read incorrectly. The options are plenty: Kiunnei Takaahai without using the Polish " $\mathrm{j}$," Kyunney Takaahay or Kyunney Takasaeva, Kunnyai Takasaeva, Kunnei Takaahai, etc. Perhaps my name will soon undergo another transformation, but I have not yet decided which name will suit me better. That will depend on the situation and the environment that I will be a part of. I noticed that the literal English translation of the meaning of my name (SunMoon) works well. I sometimes use it as a nickname, although on social networks I still use Künnej Takaahaj. For many years, I have been given a variety of names by different people, in different situations, different languages, different documents, and all this has formed my identity/identities.

\section{NAMES AND CIVILIZATIONAL CHOICES OF THE SAKHA CULTURE}

Back at the age of 11, I remember, I began to get annoyed that for their own convenience, the children at school were calling me not by my real name, and that my Yakut name was often mispronounced. And my father and I had a conversation about my name, about why my parents gave me a name that was so strange/unpopular (in the Soviet period), one which was always pronounced incorrectly. This conversation played a big role in my personal development, and I remember it distinctly, because afterwards, I started to like my name, it even made me feel a unique individuality. 
My father was of a philosophical nature and poetic mentality, and could spend a long time talking about our family name and my given name. He explained that my name could be interpreted, and what is more, could be interpreted differently in different cultures, that at the same time it was very universal and understandable for all people, regardless of nationality and where they lived. He began with the interpretation of the roots that go deep into the Turkic origin of the Sakha. He explained the origin of my Yakut surname and name. I still clearly remember our conversations about Yakut names, conversations that implicated another important issue - the identity of the Sakha people.

My name Künnei originates from Kün ("sun” and "day"), and $E i(A i)$, which in Turkic languages means "moon" and "month." Thus, my name can be interpreted as Sun and Moon, or the day of the month, or even as the Sun and Peace (Eie). The component kün is an element of many Yakut names. The epithet kün is conferred upon various male and female characters of different texts of the Yakut epic Olonkho. It is also found among the names mentioned in 17th century tax (iasak) documents as a male name (Nikolaev 2018, 15). We know that the ancestors of the Yakuts deified the sky, the sun, and other celestial bodies. Probably, the motivation of names with the kün component is associated with the common Turkic worldview of the sun cult, where the sun, sunshine, ray have an extensive semantic field, associated with the ideas of life and vitality, knowledge, and luck.

Personal names with the kün component are also represented among Altaians, Tuvinians, Karakalpaks, Kazakhs, 
the Kyrgyz, Uzbeks, Tatars, Bashkirs, Azeris, the Nogai, the Gagauz, and Turks. For example, people in Southern Altai deified the Sun and Moon, believed them superior to the host spirit of the Altai, and asked that they would grant them wellbeing in life. The Sun and the Moon were considered to be living beings by the Khakas people. On holidays they prayed to them, asking for happiness and prosperity. The Tuvinians, too, preserved remnants of direct worship of the Sun and the Moon (Nikolaev 2018, 15). According to Mongolian scientist Biambyn Rinchen, the father of the Mongolian people was believed to have been the Golden Moon, the mother the Golden Sun - thus, the Mongols are the people of the Sun and the Moon (Galdanova 1987, 15). Metaphoric names were a creation of the pre-Christian time, a creation which was subsequently lost, modified due to the introduction of the Russian anthroponomical system from the 1630s on, and due to Christianization in Yakutia. The spirit of these times is revived in the Turkic, Mongolic roots of my name.

Yakut surnames appeared in the 18th-20th centuries and were primarily associated with the Christianization of the region. They spread in two ways. First, at baptism, the Yakuts usually received the surnames of their Russian godfathers. So the Yakuts would sometimes receive the names of the priests who baptized them; for example, since the baptism of the indigenous people in the north of Yakutia by the priests Aleksei and Mikhail Sleptsov, the Russian surname Sleptsov became widespread there. Secondly, the actual Yakut surnames (like Arylakhov, Bardakhov, Kyllakhov, Tumusov, Khoiutanov, and others) were formed with the help of Russian suffixes $-o v /-e v$, -in or $-s k i$ 
from the Yakut proper names that due to Christianization became second names or nicknames, but continued to play a significant role in Yakut anthroponymy. It should be noted that the modified Yakut surnames survived mainly in two areas of Yakutia, in Tattinskii Region (Ulus) and my native Verkhneviliuiskii Region. Some people can determine where I come from just by my last name.

Takaahai, my paternal surname, appears only in the locality where I was born, i.e. the village of Nam, Verkhneviliuiskii Ulus, Western Yakutia. My surname originated from the nickname of my ancestors. In some cases, nicknames derived from some external characteristic of the person, in others - from their personal qualities, their position in the family, their relatives, or their occupation. A family nickname, on the other hand, was used regarding the whole family, could be inherited, and although unofficial, it could replace the official surname and become the basis for the names of the wife and children. It is often difficult to restore the history and time of occurrence of such nicknames.

In the case of my ancestors, the family nickname which gave rise to the surname Такааһай (Takaahai) presumably comes from the Yakut word takaiar - "to improve something, to teach, to train." There is also another possible interpretation of my last name, associated with gait, i.e. a special way of walking (for example, limping). From the archival data gathered as we tried to restore the family tree, we know that our surname was modified, but its original sound was Takaahai:

- Takaahai (Такааһай) Semion (b. 1790) - my great-greatgreat grandfather; 
REFLECTIONS ON NAME AND IDENTITY: "WHAT DO YOU SEE...

- Takasii (Такасий) Ivan Prokop'evich (b. 1831) - my great-great grandfather;

- Takasaev (Такасаев) Ivan Ivanovich (b. 1867) - my greatgrandfather;

- Takasaev (Такасаев) Timofei Ivanovich (b. 1912) - my grandfather;

- Takasaev (Такасаев) Revolii Timofeevich (b. 1942) - my father, lived a life without a father.

So, my Yakut surname Takaahai was Russified and at least from 1867 began to be written in documents as Takasaev. The Yakut version of our surname is known only in our village and until now we are identified by this name. In the Yakut plural we can be called Takaahaidar - this means "those from the Takaahai household." I have to add that I have tried several times to start a discussion with my sisters about the possibility of registering the correct version of our surname: Takaahai, not Takasaeva. Although this official name change to the Yakut spelling would cause some difficulties with the re-issuance of all documents and so far has not been possible, I decided to keep the Yakut version of my name as a pseudonym and on the title page of my PhD thesis, where next to the official name recorded in my passport, an inscription in parentheses says: (Künnei Takaahai).

Our father was very worried that after his daughters marry, we would change our surnames, and our family name would disappear, since he was the last of his male line and had no son. It was important for him to pass the last name along. Thus, when my sisters and I were still children, we decided not to change 


\section{Kyunney Takasaeva (Künnej Takaahaj)}

our original surname after marriage in order to preserve both the name and ancestral memory. When my sisters were about to have children, my father even had conversations with them to ensure that at the birth of their sons they would give our last name to one of them. When the time came, father insisted that his eldest grandson should be a person to inherit his surname. My sister agreed and, moreover, her son got his first name in honor of our father - Revolii Takasaev II. Revolii recently got married, and his young spouse took our last name. Now one can meet only six people in the world with the surname Takasaev: my father's three daughters, his eldest grandson - and namesake - his wife and their daughter. I think our father was proud that he managed, through some efforts, to preserve his original Yakut family name. As for me, on the one hand, thanks to my last name, I am directly connected with the history of my people, with the Yakut culture and epic which is deeply rooted in the Turkic world; on the other hand, my given name represents symbols universal for all of humanity.

On top of that, I want to add that my paternal grandmother, Stepanida Vasil'evna, bore the Polish surname Kardashevskaia, as she was an adopted daughter of Baai Kinees Kutaskyyn (an anthroponym comprising the words baai - rich, kinees high-ranking elder and the Yakut given name Kutaskyyn), whose official name was Ivan Leont'evich Kardashevskii. One can still find Polish noble surnames in Yakutia, some of which are now rarely met even in Poland (for example, Iavlovskii, Piletskii, Zaborovskii, Krzhyzhanovskii, Gromadzskii, etc.). This fact is associated not only with the exile of Polish people in the 
wake of the 19th century uprisings, but also with migration to Siberia for professional or economic reasons. The story of how the Kardashevskii surname first appeared in Western Yakutia is very interesting. In 1805-1816, a certain Pole, Ivan Grigor' evich Kardashevskii, was the head of the Yakutsk region, and before that he served in the Viliui District. He had a reputation for having good relations with the local rich people, who highly appreciated and respected him. It is difficult to say how reliable this information is, but legend has it that when he left Viliuisk, he gave his surname to Legentei, the ancestor of the Kardashevskii clan in Verkhneviliuisk. This fact is described in the book Pre-Revolutionary Chiefs of the Yakutsk Territory, where historian Fedot G. Safronov notes: "When he was in Viliuisk, Ivan Grigor' evich Kardashevskii became quite close with the Yakuts, and at baptism some of them accepted his surname" (Safronov 1993, 38). Thus the Polish surname Kardashevskii spread on the Viliui River.

On my mother's side, there is Slavic blood in my family: my great-grandmother Anna Gromova - mother of my maternal grandfather Dionisii Innokent'evich Krivoshapkin - was from a Don Cossack family. According to a family legend, she came from a family of Siberian gold miners from Bodaibo and it is allegedly these Gromovs that are the main characters of Viacheslav Shishkov's famous family saga Ugrium reka (1933).

Through each one of my names, each place of residence, I am associated with a huge number of people - not only with my home village, but also with the history of an entire people, which emphasizes my individual history and my uniqueness among 
others. The history of a family is capable of comprising the history of a people in a condensed form, and so my transforming family name reflects subsequent periods in general history of the Yakuts. As my example shows, in Yakutia, historical periods can be traced through personal names. The local culture, the process of Christianization (Russification), and then the onset of the Soviet period - each was marked by the presence of a separate naming tradition.

\section{CONCLUSION}

After the collapse of the Soviet Union, one can trace a trend of returning to indigenous names. From the 2000s on, it becomes very popular in Yakutia to give children Yakut names. Today, there exists an official list of Yakut names of the Sakha Republic, used when registering newborn children. This is very different from the situation of my childhood, when I was one of the few children with such name. There are also precedents when adults change their names to Yakut ones in the official documents, for example, Egorov Eduard Anatol'evich transformed into Dokhsun Kuogkhaiaan or Nikolaeva Anna Petrovna became Tuiaara Alaas. They and others like them do so in part because throughout the history of Yakutia, Yakut names were not preserved in official documents.

I count my peers in Yakutia among the generation of the transition period, a generation that saw what might be called a borderland of historical eras take place before our eyes. We caught the sunset of the Soviet stagnation period, but did not 
have time to be fully involved in it before it was swept away by a period of great historical changes on a global scale. The transition period led to the search for and revival of local ethnic identity in Yakutia. Memories of this transition are rooted deeply in my self, it is these memories that allow me to delve into the history of my own Sakha people. I think, however, that an even deeper understanding of the uniqueness of the Yakut culture came to me thanks to my involvement in a different cultural milieu (in Poland), and this I saw as a certain privilege. It was while away from my homeland, taking part in discussions about the search for identity in the Polish academic environment, that I began to formulate questions about my own identity.

Being inside a culture, we do not particularly notice its features, and when one finds oneself in a different environment at a certain distance, one begins to analyze consciously one's self, find differences, appreciate them and look for opportunities to accommodate to the environment while preserving one's original, birth-given culture. This happened when our family moved from a small Yakut village to the Russian-speaking capital of Yakutsk. It happened again in my student years in Irkutsk and later in Moscow, but it was only when I came to Poland, a country with a history different from that of Russia, that I began to dive into the ups and downs of Yakutian history. Gradually, I introduced my colleagues to various features of the Yakut culture by placing it in the context of borderlands, which allowed us to see that the Sakha culture belongs simultaneously to several civilizational circles, such as the Turkic, Mongolian, Arctic, Eurasian, and Siberian ones, and to see the 


\section{Kyunney Takasaeva (Künnej Takaahaj)}

transformations that its people have been undergoing throughout history. I regard Yakutia as a borderland and a space of dialogue among a diversity of cultures, where vast territories and harsh climate conditions make it impossible to live without developing qualities such as communication, dynamism, tolerance, diplomacy, and coexistence. Despite the conflicts that arise, there is always a spirit of reconciliation.

Our globalizing world is such that we no longer live in the reality in which we were born and cannot adhere to only one identity throughout our lives. During their lifetime, some leave the places where they were born, others, without going anywhere, simply cannot recognize their places of origin. In modern times, we are forced to learn foreign languages and other cultural codes that are different from those of our ancestors, and anxiety arises over our identity - the threat of losing it when we accept, or find ourselves in, another culture. It is often possible to alleviate the tension and create a friendly climate between different groups, but this is a very delicate process and one should not enter it lightly because it can easily lead to the opposite effect. For example, wanting to help some minority, the majority can push it into a reservation or ghetto from which it can no longer get out.

One might say that I have been searching for myself in changing conditions in order to protect my own identity. With each new place or culture, I had to explain my name in order to preserve the existing codes related to my background and to emphasize my original Yakut identity. Perhaps this is also related to the problem of identity conflict in the time of globalization, 
about which Amin Maalouf asserts: ultimately each of us is the custodian of two legacies - one emanating vertically from our ancestors, the other horizontal, which emanates from the epoch in which we grew up, and from our contemporaries and these vectors can intertwine. For example, I have more in common with a doctoral student from Poland than with my own great-grandmother, despite outward resemblance, and in this respect, my search for a balance between the loosely defined "traditional" and "modernist" components of my identity will determine my personality. In my particular case, the threat of the disappearance of cultural identity in a period of globalization affects the ambivalence of identity and is associated with the need to develop two mutually exclusive processes - protecting identity and simultaneously finding ways to adapt it.

\section{REFERENCES}

Bolo, Sesen I. 1994. Lieneghe nuuchcha kelien innineeghi sakha ologho: Urukku D'okuuskai uokuruk sakhalaryn bylyrgytyttan kepseennerinen [The past of the Yakuts before the Russian arrival on the Lena: According to the legends of the Yakuts of the former Yakut District]. Iakutsk: Bichik.

Bravina, Rozaliia I. 2015. "Antroponimiia iakutov v trudakh F. G. Safronova" [Anthroponymy of Yakuts in the works of F. G. Safronov]. Severo-Vostochnyi gumanitarnyi vestnik 1 (10): 61-66.

Galdanova, Galina R. 1987. Dolamaistskie verovaniia buriat [Pre-Lamaist beliefs of the Buryats]. Novosibirsk: Nauka.

Kharitonov, Leonid N. 1947. Sovremennyi iakutskii iazyk: Fonetika i morfologiia [Modern Yakut language: Phonetics and morphology]. Iakutsk: IakGiz.

Maalouf, Amin. 2003. In the Name of Identity: Violence and the Need to Belong, translated by Barbara Bray. New York: Penguin Books.

Nicolaisen, Wilhelm F. H. 1999. "An Onomastic Autobiography, or In the Beginning Was the Name." Name: A Journal of Onomastics 47 (3): 179-90.

Nikolaev, Egor R. 2018. Iakutskie lichnye imena: Lignvokul'turologicheskii aspekt [Yakut personal names: The lingual-cultural aspect] (Summary of PhD thesis). Yakutsk: Institut gumanitarnykh issledovanii i problem malochislennykh narodov 
Severa SO RAN. Accessed July 1, 2018. http://igi.ysn.ru/files/news/razmeshenie/09.02.2018/files/avtoreferat_NikolaevER.pdf

Safronov, Fedot G. 1985. Dokhristianskie lichnye imena narodov Severo-Vostoka Sibiri: Istoriko-etnograficheskii obzor i imennik [Pre-Christian personal names of the peoples of the North-East of Siberia: Historical and ethnographic review and name book]. Iakutsk: Knizhnoe izdatel'stvo.

Safronov, Fedot G. 1993. Dorevoliutsionnye nachal'niki Iakutskogo kraia [Prerevolutionary chiefs of the Yakutsk Territory]. Iakutsk: Sitim. 


\section{Wojciech Cendrowski \\ ORCID 0000-0002-1884-3386 \\ University of Warsaw}

\section{A BLUE COLLAR \\ AS AN ETHNOGRAPHER: \\ A FEW REFLECTIONS ABOUT \\ ETHNOGRAPHIC FIELDWORK \\ IN THE CONTEXT OF THE \\ POLISH UNIVERSITY}

Ethnographic fieldwork is the main marker of socio-cultural anthropology. The research methodology proposed in the early 20th century by Bronisław Malinowski revolutionized ethnology and it is still relevant today. Of course, for decades researchers have preferred different ways of collecting data. Apart from interviews and visual observation, these have included also experience gained by the senses of taste, touch, and hearing. In a nutshell, anthropologists transform their own bodies into research tools. The close connection between the ethnographer and a place of fieldwork is undeniable. All of activities which we undertake have an influence on us and our research partners; the experience of fieldwork thus changes both ourselves and our interlocutors (Kairski and Buliński 2015, 5-6). Postmodernist 
anthropologists suggested that there was no objective knowledge in the ethnographic endeavor - they pointed out that ethnographic research could look only for an inter-subjective point of view. As a consequence, ethnographers have stopped being invisible. We have started to be present in our texts. Additionally, we invite our interlocutors to be coauthors of our books and articles. ${ }^{1}$ The anthropological community has gained awareness that even if the topic and the site are the same, different researches will yield different results. For instance, during ethnographic fieldwork, each researcher might establish rapport with different persons, and various unexpected accidents might elicit emotional reactions. Aware of these realities, anthropologists have abandoned positivist theories of knowledge, focusing on the inter-subjective character of the collected data. Such factors as the experience of researchers, new theories, regular exchange of ideas, including conversations with other researchers, can influence our personality and have impact on our scholarly interests and approaches to knowledge. This influence is a part of what has been referred to as serendipity (Bloch 2016; Hazan and Hertzog 2012). Most descriptions of serendipity in anthropological investigation treat it as a strike of chance that can change direction of research, provide answers to research problems, and, last but not least, be helpful in choosing the subject of our interests. Below I provide a short discussion of the specific kind of serendipity in the trajectory

${ }^{1}$ As an aside, I would like to mention that within the ecological humanities, which strive for knowledge that is non-anthropocentric, non-European-centered, and goes beyond the nature-culture dichotomy, the most radical propositions involve incorporating the other species as contributors (Domańska 2013, 31). 
of Polish anthropology, predicated on the assumption that the 19th century plays the key role in the history of anthropological investigations.

All around the world, anthropology has been a discipline closely related to the political situation. Especially at its outset, this meant engagement of anthropologists in colonialism. Europeans had the opportunity to conduct their research because they could organize expeditions to their colonies. The situation in Poland was quite different. In the 19th century, the territory of Poland was divided between three counties, the Austrian Empire, the Kingdom of Prussia, and the Russian Empire. In the second part of the century, many Poles were persecuted for terrorism, participation in uprisings, and disloyalty, especially on Russian territory. The common punishment for these crimes was exile. One of these exiles was Bronisław Piłsudski, who took part in an attempt to assassinate Tsar Alexander III and was sentenced to hard labor on the Sakhalin Island. However, his relegation transformed into ethnographic research on the Ainu people. Wacław Sieroszewski was likewise punished for political activity. He was exiled to Sakha, where he also started to conduct ethnographic research. Yet not only exiles had the opportunity to conduct research beyond Europe. Bronisław Grąbczewski was an officer of the Imperial Russian Army who left plenty of ethnographic fieldnotes regarding Central Asia. Maria Czaplicka and Bronisław Malinowski studied in England and that laid foundation for their later fieldworks: Czaplicka investigated the Evenki people in Siberia, Malinowski explored Papuan islands. In my opinion, both of them played a key role 
in the development of ethnographic research methodology, even if it was only Malinowski who became known as a father of social anthropology. When Poland regained independence in 1918, there was a rich ethnographic tradition, so institutes of ethnology/anthropology which were created in the reborn state could rely on experienced fieldworkers. Unfortunately, the general situation in the Polish university system has not allowed to conduct research according to Malinowski's directives. Instead, Polish research has mostly built on another tradition from which it stems: that of fieldwork conducted close to home, usually in multiple shorter stays. The history of Polish academic tradition in ethnology during the 20th century deserves a separate monograph, and shorter attempts to present it were undertaken by such prominent scholars as Buchowski (2012), Jasiewicz (2018), Posern-Zieliński (1995). In keeping with the topic of this volume, having drawn the historical background for my considerations, I would like to focus here on my personal experience in conducting fieldwork and my own reflections about the condition of ethnology and anthropology in the Polish university system.

SOME GENERAL PROBLEMS

REGARDING THE FIRST EXPERIENCE

OF ETHNOGRAPHIC FIELDWORK

My training as an anthropology student at Adam Mickiewicz University in Poznań included a course called Methodological Laboratory, which consisted in a two-week-long group research 
trip. The coordinators of each group chose an area and prepared a research topic. Students from my cohort conducted research in Malbork, a town in northern Poland with almost 40,000 inhabitants, famous for its 13th century castle, which is listed as a UNESCO World Heritage Site. Students were divided into four groups and everyone explored different topics, from folklore to political economy. Within Methodological Laboratory, the choice of destination depends on the coordinator, number of students, and financial support. Among the fieldwork sites in other academic years were towns and villages like Szydłowiec, Dubicze Cerkiewne or Ludwikowice Kłodzkie.

Obviously, there is initial training in data collection during earlier semesters. The obligatory courses before the laboratory were Ethnographic Interview, Ethnographic Observation and Methodology of Ethnographic Research. The aim of these courses is to acquire and train basic skills in collecting data. Unfortunately, the basic textbooks of ethnographic research methodology are written by representatives of other social sciences, like David Silverman, Martyn Hammerley, and Paul Atkinson (Buliński and Kairski 2013, 13), who do little to emphasize the specifically anthropological tradition of fieldwork. The books written strictly by anthropologists are marginalized in the Polish publishing space and Polish academia. ${ }^{2}$

Despite this downside, the methodological courses are really helpful in developing research skills in young anthropologists.

\footnotetext{
${ }^{2}$ One example of an interesting anthropological work which addresses the influence of chance on fieldwork is Nigel Barley's The Innocent Anthropologist: Notes From a Mud Hut (Barley 1983). In Poznan, it is obligatory reading for the course Ethnographic Observation.
} 
However, there are a few obstacles to this way of educating new generations of fieldworkers:

- Lack of possibility to gain meaningful experience in research.

- Problem with funding research projects within the Polish university system.

- Confusion among anthropologists as to the characteristics of fieldwork and the topics for anthropological considerations.

The two-weeks-long group trip is the only fieldwork that is compulsory for all students. They are encouraged to conduct their own fieldworks as basis for bachelor's and master's theses, 210 but this is not funded and therefore not obligatory. An undoubted advantage in this regard is the fact that academic teachers organize additional fieldworks as electives, spending their own time to look for financing. Thanks to them, many of the students have an opportunity to learn much more about methodology of ethnographic research and use this knowledge in practice. In my opinion, one of the brightest cases has been a project coordinated by Natalia Bloch, called "(Re)gained Migration Memory," which was part of a multi-stage program. The course was based around letters of Polish emigrants in the US and Brazil, collected by Witold Kula. The main idea of fieldwork was to find the addressees of these undelivered letters. It was also a plea to investigate the influence of migration on the collective memory of modern locals. The result was the publishing of a book comprising a reportage as well as exhibition catalogue and educational program (Bloch 2016, 13-22, 155-56; Bloch 2017, 
337-39). This, however, is only one case and it is important to notice that the endeavor was financed from outside sources, so it, too, speaks to the shortcomings of the Polish university system.

Anthropologists who work in Polish universities have to deal with bureaucracy, underfunding, institutionalization. They have to organize their fieldwork in lieu of holidays. Additionally, authorities do not understand the necessity of intense and long-term research stays as a base for collecting material in anthropology (Kaczmarek 2016, 124). These problems impact both teachers and students. If a student wants to conduct their own research, they must find ways to finance it and the time to conduct it. The program of studies does not allow for additional time for the fieldwork one might deem necessary in order to prepare a satisfying thesis. As I am writing these words, the situation is changing dramatically for the worse. In 2018, The Ministry of Science and Higher Education decided to remove anthropology (ethnology) from the list of recognized scientific disciplines and hide it within a new category, labelled Cultural and Religious Studies. This decision will be a source of problems in terms of international cooperation, and it has met with protests from scholars from Polish universities, their students, and international societies. The next, albeit arguably related, blow was a change in the so-called cost intensity ratio of disciplines (Dohnal 2018, 15). Before the new regulations, anthropological institutions received $50 \%$ of the maximum financing quota. According to the new law, Cultural and Religious Studies institutions will get less than $17 \%$ of the maximum amount. This will impact the quality of education 
and limit obligatory ethnographic training. The other disciplines categorized as Cultural and Religious Studies do not practice long-term fieldwork, which considerably lowers the costs they incur. The cost intensity of socio-cultural anthropology should be similar to that of archaeology, as was the case before the changes in legislation.

The Polish university system offers tuition-free education for a considerable part of students but almost no real scholarship opportunities. As a result, most attendees reconcile studies with gainful work. Some students even spend part of earned money for their fieldworks. In the case of anthropology, this is another factor exerting a serious impact on long-term ethnographic 212 fieldwork, and thereby on the core of the discipline.

Thus, presently, newly-enrolled anthropology students in Polish universities can but learn about Malinowski, his achievements and about his ground-breaking method consisting in the imperative to spend a minimum of one year on intense research. Granted, the more than one hundred years that have passed since the time of Malinowski's fieldwork on the Trobriand Islands have brought about changes in the scope of the discipline. Decolonization was one of the most important factors. Anthropologists worldwide have started to conduct research in familiar areas, among different social and ethnic groups. The discipline has changed in terms of methods and ethics. Yet participant observation is still the core of ethnology and the main way to collect empirical material. Additionally, the time of fieldwork is not only a requirement of valid research but also a rite de passage for an anthropologist (Sokolewicz 2016, 141). 
Today, however, apart from scholars who conduct fieldwork, there are those who look for a subject of research that does not require it, for instance music, literature or cinematography. One of the side effects is an absence of discussion about ethnographic fieldwork, a trend that conduces to a blurring of anthropology as a discipline and to a degradation of its scientific language, which gets substituted with journalistic writing. Another problem is that some scholars use the word "research" to refer to expeditions which are closer to summer trips than to serious ethnographic observation (Buliński and Kairski 2013, 12, 14). Some Polish anthropologists conduct fieldwork that has more to do with quantitative research than with ethnography, and consists in conducting surveys, sometimes without a deeper understanding of the observed phenomena. Additionally, they use a specific jargon borrowed from the other social sciences, which may be considered more professional by an outsider but, in fact, is strange to anthropological traditions. The confusion among scholars is replicated among students, who end up losing interest in anthropology. This is in close connection with the irresponsible financing of anthropology, due to which people entering the discipline lose an opportunity to practice participant observation, and instead of expeditions base their projects on questionnaires and judge their work by sheer number of interviews, which in theory are the base for fulfilling the scientific requirements of the discipline (Kaczmarek 2014, 119-23). 


\section{ANTHROPOLOGY AT HOME, WITHIN ANOTHER JOB ${ }^{3}$}

The key question for an anthropologist, then, is how to organize and conduct fieldwork in modern political and economic conditions. And, as it is almost impossible to study in contemporary Polish university system without simultaneous gainful employment, another question is how to support yourself before fieldwork can even start. I myself resolved both these issues by working as an assistant technician for a third-sector theater group. However, my work there, and the fact that it enabled me to be at the right place and the right time to undertake my fieldwork - were also effects of serendipity.

In September 2013, I had the opportunity to see the 20th jubilee of The Zone of Silence Theater in the center of Poznań. This happened by sheer accident. I was crossing the street when I noticed a few strange parades - sportsmen, Santa Clauses, pregnant women. They met in Liberty Square and started to dance polonaise, incorporating pedestrians to this unwonted affair. At the end of the happening, the information was passed along the street that there would be a performance and party at the theater. I decided to go there.

The place was interesting and charming. It was close to the center of the city, no more than six minutes from the railway station by tram. The theater was situated in a wooden barrack, surrounded by trees and bushes. At the same plot

${ }^{3}$ In this and next sections, I used material from my master's thesis (Cendrowski 2016a), written in the Institute of Ethnology and Cultural Anthropology, Adam Mickiewicz University in Poznań, under supervision of Prof. Jacek Schmidt. 
of land there was also a driving school with a little training yard. It was evening when the show started. It was called Peepholes (Judasze). The story focused on a wedding and all spectators were invited to take part in dancing, eating and having fun. There were about one hundred spectators/guests. The performance transformed into a party with live folk music. At the end of the show, I decided I would ask whether I could volunteer at the theater.

At that time, I worked in a student work collective. The institution collected tasks from employers and then looked for students who had time to fulfill those tasks. This system was convenient and could be reconciled with both studying and getting another job. On the next occasion when I went to The Zone of Silence Theater, I asked if I could talk to the manager, because I would like to volunteer in the organization. I was led to a man who announced they did not need additional volunteers, yet asked about my previous jobs. I answered that I had been a technician during Malta Festivals ${ }^{4}$ and I had some experience as stage fitter during musical events. He referred me to the superior of the technician section, who asked me to come back in a few days in order to help with preparations for the next show. Two weeks later, the theater offered me a regular, paid position. I had a flexible schedule which depended only on the repertoire and my free time. Of course, I did not suppose then that I would stay there for the following two years and even more.

\footnotetext{
${ }^{4}$ The Malta Festival started in 1991 as an annual international theater festival. Over the last few years, the programs have come to include more events from other disciplines of the arts, like dance, music, and film.
} 
Simultaneously, I continued my ethnological studies at the master's level. I was a bit confused when looking for the topic for my thesis. There was an idea in my mind to conduct research in Siberia, but I had never been to Russia and felt my knowledge was not sufficient. For sure, it was impossible to find financial aid for this project. More important than my dream about faraway expeditions was the imperative to collect reliable data using ethnographic methods. That is the reason why I decided in favor of conducting research at home, in Poznań. But still, I had no research problem. I was interested in urban studies, so I decided to look for advice from the staff at my Institute. Someone gave me a tip to focus on Główna district. This neigh216 borhood was an example of the category of the in-between city, a space between the classical city and the suburbs. The architecture is more similar to downtown, but there are industrial plants around. This kind of district should be located near a highway and, one of its most important traits, be completely invisible to the rest of the city. The Główna district fit this category. It also had one of the highest crime rates in Poznan, but that was not the main problem for me. I found people who could introduce me to the local communities, so I could use the classic snowballing strategy. What proved most problematic was finding the time to reconcile studying, gainful employment, and quasi-ethnographic fieldwork. Renting an apartment in Główna was beyond my possibilities, so my involvement was narrowed to a small number of interviews and some informal meetings, which was not enough to satisfy my idea of the ethnographic method. Yet by chance, a helping hand was lent to me by a more 
experienced colleague, who played the role of my mentor in socio-cultural anthropology.

At first, it was really a casual conversation. I said something about problems at the theater. The hospital located across the fence from the barracks submitted to the municipal authorities a proposal for developing its infrastructure, which involved incorporating the adjacent 5.6-hectare plot where the barracks stood. The municipality agreed to this proposal, and so the theater had to look for a new residence. However, the space was used not only by the theater. There were a few NGOs, private entrepreneurs as well as local inhabitants. In fact, the problem was big. Suddenly, my older colleague asked,

"What is your fieldwork for the master's thesis?"

"I have taken on too many duties, so I can't find the time."

"Did you think about changing the topic? You could write about the shanties."

His idea was very clear and simple. If I became member of one from the local groups, I could use my personal experience in anthropology. The problem of eviction would be my problem, just like it was the problem of other users of the plot. My affiliation in the theater would allow me to hang out with locals and people who visited the barracks. The idea was tempting, so I prepared a research proposal and presented it to my supervisor. He had no objections, and so I started the research project. I used some of my previous reflections and recollections as ethnographic material. Academic ethics requires the researcher to be transparent: it is morally suspicious to undertake covert participant observation. Therefore, I started out by talking to 
my colleagues and superiors at the theater, and securing their permission. From then on, I began to spend much more time in the barracks. Beyond my job as assistant technician, I started going around and talking to people. My employment at the theater was an additional advantage because after finishing work I would often meet spectators who stayed after the show for a glass of wine and a sophisticated conversation. Additionally, the driving school instructor regularly visited our shanty to drink coffee and take a break. Unfortunately, the topic turned out to be more complicated than anticipated, as the situation proved too difficult for some actors to successfully resolve.

As a person holding a bachelor's diploma, I should have been performing some kind of intellectual or office work. There is a glamorous word to describe this kind of people: "whitecollar." On the other hand, there are plenty of people who support themselves by manual labor and there is a collective phrase for them as well: "blue-collar." Occupations for bluecollar workers can be described as "3Ds jobs": Dirty, Dangerous, and Demeaning. This is the kind of job that technicians do. There are a lot of manual and physical activities that have to be performed and it is technicians that perform them, while all the applause is reserved for actors, directors, and scene designers. The technicians create the background and they become the background. It was April of 2014 when I started to conduct research in my workplace. This new circumstance caused problems with my identity or, to use theatrical vocabulary, with my role. Before this, I had a simple identification - I was an assistant technician in a theater, that is a blue-collar worker, 
and at the same time a part of a bigger artistic collective. Then I changed into an ethnographer, a person who uses his theoretical knowledge in order to collect empirical material. These two roles I played simultaneously; however, in different situations I was forced to balance between them. This prompted me to create a word connecting these two roles, "blue-scholar," which can be used to describe all of the scholars who conduct research in the conditions of a different, physical occupation. This neologism can be a useful term to refer to ethnographers who undertake fieldworks in factories. An excellent case of a "blue-scholar" is Elisabeth Dunn, who collected material about the economic transition in post-socialist Poland during, among other occasions, manual work in food production (Dunn 2004). My situation was similar; however, my interests were totally different. My idea was to use ethnographic research to tell the story about shifts in urban space and show the interactions between particular subjects active within this space. I treated both people and organizations as actors, without forgetting that there was a huge discrepancy between their agencies. In the simplest way, my subjects could be categorized in three groups:

- The hospital and the University of Medical Sciences that runs it, which planned to incorporate the barracks and the surrounding territory.

- The Jan Ostroróg Society, uniting neighbors from historical villas surrounding the plot.

- Inhabitants of 55 Grunwaldzka Street. Among them, I counted individual families, NGOs, and private 
entrepreneurs who used the shanties. This category was the most heterogeneous one.

All of these groups were obligated to play according to the rules and laws assigned by the city, the state, and the European Union. The game showed how the global rules worked in a micro scale. My access to these groups was very different and was determined by all of the features of my position. It was obvious that I would not be able to talk with everyone (which, in any case, is non-obligatory). In theory, I should have had the best contact with other users of the land, but that proved not to be the case. Of course, the biggest problem was posed by interactions with the hospital. I tried to talk with someone who could tell me more about the development strategy and about the decision previously made by the management of the grounds - in the past, the University of Medical Science decided to allow for building a gas station and store instead of emergency department at the other plot of land in close neighborhood, which was zoned for the purposes of healthcare. My emails were met with short, laconic answers. The lack of willingness to continue the conversation was best shown by the answer I got to the question about financing sources for the investment. The answer read: "THE MONEY WILL BE THERE."

A typical day of my research started in the theater. I would leave my post and go around the shanties. That was an attempt to engage in what has been described as "deep hanging out" (Kaczmarek 2013, 37), but paradoxically it was not so simple. There were a few characteristic points within the plot. Some of them were buildings that were empty by the time I started to 
conduct my investigation. Empty, however, did not mean useless. One of them was an abandoned wooden building with two floors, which was used by three homeless persons. I attempted to talk to them, but they started to shout at me. In the shortest and most polite paraphrase, they proposed that I leave them alone as quickly as I could. That was surprising because one of them would often come to the theater to ask for hot water or to charge his cell phone. At those times, he was extremely talkative, although I suppose it could have been a strategy undertaken merely to accomplish a goal. On the other hand, he could have not recognized me, because it was dark. The homeless had a surprising method of keeping their stuff safe. They had a blue car, an old Fiat 126p, which was completely wrecked but the lock was in good condition, so they used it to keep their things. After the decision was made to pass the land to the University, city guards attempted to remove the homeless people, but after every intervention they came back. Then, one morning in the spring of 2015, police officers came to the theater. They asked if the homeless people were present at the premises. We confirmed their presence, but nobody knew any personal details about them. When asked about what had happened, the police officer showed us a photograph of a dead body - it was one of the homeless persons. At the end, the deceased man's friends left the shanties but they put up a wooden cross at the place where they'd lived.

The problem with the willingness to talk concerned not only the homeless. The families living at 55 Grunwaldzka Street represented different approaches. One woman did not 
open the door, but we had a short conversation. She said that she could not talk with me when her husband was absent, so I had to come back later. When I did come back, her husband said that he was pretty happy to leave the place and that was all. Another man, who had lived in the barracks for 20 years, invited me to his house and started telling stories about the estate. I collected material about some past establishments, such as the bakery which had been situated there in the times of the Polish People's Republic. The man also told me about a club named Arizona, where people would meet for dancing, which had been located in the shanty where the theater now resided. I got similar information from the other talks, but there was a different problem, as well - some interlocutors were not sure about specific locations. Not so far from Grunwaldzka Street was a second complex of barracks, located at Sowińskiego Street. That was the reason why some histories got mixed up and caused problems in determining the specific location of some events. However, there were certain orientation points. In the case of the Arizona dance club, for instance, the fact that Grunwaldzka at one point housed dormitories for students of the University of Physical Education made it possible to assume that a dance club could have been established in close neighborhood.

An interesting finding were the attempts at legitimizing the presence of the theater in that particular place. According to the words of one of my interlocutors, Jerzy Grotowski, the famous Polish theatrical director and one of the most important reformers of theater in the 20th century, organized his rehearsals at the shanties. According to this story, Grotowski used the very 
barrack which later became the theater center. I tried to find any evidence which would confirm these words, but I was unable to. In my opinion, it is only an urban legend, but it could have been used as a pretext to locate the theater in this specific place.

I abandoned this topic in 2016, but the only reason for that was the obligation to defend my master's thesis. The process of spatial cleansing is now complete, but at the time of writing these words the story of the modernization of the hospital is still ongoing. Local activists, like the Green Grunwald Initiative, still fight to preserve green areas in the district. Especially since the University of Medical Sciences has changed the project and it now wants to develop a much greater Integrated Medical Center. Within this monumental project, the University wants to move four clinical hospitals to the Grunwald district. This poses a risk not only to the district itself but to the entire city. The clinics are currently in the strict city center and are located in historical buildings for which it will not be easy to find new use. From this perspective, the removal of the shanties has served the purpose of changing the urban space of Poznan for the following ten years, and beyond. The modernization of the hospital is set to be complete by 2027 .

\section{CONCLUSIONS}

The conclusions to be drawn from my research experience are diverse, from the most general to more specific ones, and they have to do with the discipline, the Polish university system, and research ethics. 
Firstly, there is a basic problem with financing the educational system. Even students who are awarded scholarship for outstanding results cannot survive without support of the family or additional gainful employment, which in most cases is not correlated with the direction of studies. In the case of anthropologists, there is the additional problem with the financing of fieldwork. Complicated as this was in the past (Kaczmarek 2014; Kaczmarek and Ladykowski 2012), with the contemporary changes in the system of higher education, the situation is going to get worse. Due to the decrease of the cost intensity ratio for anthropology, the financing will be too low to allow for every student to do obligatory research during studies. On top 224 of that, everyone should conduct their own fieldwork, which constitutes an additional cost.

The second conclusion is my strong recommendation to conduct one's own fieldwork. Of course, anthropologists should still realize faraway expeditions, but sometimes it is (almost) impossible to find the funding and time to do that. If that is the case, a good strategy is to conduct research at home. Yet anthropology at home is not without its problems: in everyday life everyone has a lot of duties with their job, school, family, friends, and so on. The advantage of ethnographic observation done far away is leaving all that at home and immersing completely in fieldwork. In any case, however, regardless of where the research takes place, participant observation is our main method to collect data and it should be the base for the majority of anthropological research. It is the discipline's core. Obviously, if a researcher decides to collect materials using also different methods, he or 
she may do so, but in my opinion, those different tools should be used only if participant observation is not enough.

I also must point out the next methodological problem, which is associated with time. I do not mean work-life balance, which, as mentioned above, plays a key role when it comes to anthropology at home. The point is that each project has a deadline, but social life is an extremely plastic material and situation changes over time regardless of dates. This can be caused by economic considerations, private trajectories or changes of concepts. My research shows that it can be impossible to end the fieldwork in the allotted time. I defended my thesis one year after receiving the certificate of completion of higher education. I wanted to collect material and to write a satisfying thesis, therefore I decided to spend more time doing fieldwork. However, a lack of financing and access to key social actors and settings on the one hand, and new visions of the development on the other hand, have meant that the project had to be abandoned. Yet the situation is still in progress. In my thesis, I had to give some prognoses regarding the influence of the modernization on the local communities and urban landscape. It lost its validity almost immediately because a new idea of Central Integrated Hospital appeared at the beginning of 2017. As Edmund Leach noticed, "it is just as difficult to reconstruct the past as it is to predict the future" (as quoted in: Buchowski 2010, XXXII).

Another conclusion is that research is strongly enhanced when undertaken for the common good. Researching a national minority, an emancipation movement, or ways of participation 
in the public space can offer a possibility to introduce the voice of our research partners into the public debate. In this context, I would like to remind the words of Michael Herzfeld, "We are not that important, but we can be useful" (as quoted in: Bloch $2015,53)$. The authority of a researcher can be helpful for the investigated community. Our articles function in the social reality and they can impact its shaping. Our analyses can be helpful in bringing about a more sustainable space, safe for and respectful of all the local communities within it.

Last but not least, the greatest takeaway from fieldwork is the personal experience of each researcher. While collecting material for my master's thesis, I learnt a lot about methods of researching urban areas and about ethnographic fieldwork. In 2015, I visited Siberia for the first time. I was determined to find a fascinating topic for my next research project. My predictions as to what the project might be, based on literature, awareness of the distance between important Siberian urban centers and preliminary knowledge about the ethnic situation, proved accurate: the relation between perception of space and group identity is an important and topical research problem. This relation impacts the processes of urbanization, ways of life, styles of using the cities, and ways that the presence of different ethnicities is marked in urban space. I got the chance to verify and develop these interests within the seminar "Searching for Identity: Global Challenges, Local Contexts" at the Faculty of "Artes Liberales," University of Warsaw. It constituted a demanding yet rewarding school of studying identity in multi-level contexts. 


\section{A BLUE COLLAR AS AN ETHNOGRAPHER...}

\section{REFERENCES}

Barley, Nigel. 1983. The Innocent Anthropologist: Notes from a Mud Hut. London: British Museum Publications.

Bloch, Natalia. 2015. "Badacz rozgrywany i wewnętrzne gry interesów w społecznościach narażonych na nadużycia: O problematyczności antropologicznego zaangażowania" [The researcher being played and the internal power games in abuse-prone communities: On the problematic nature of anthropological engagement]. In Etyczno-moralne aspekty “praktyk humanistycznych,” edited by Marcin Kafar and Adam F. Kola, 53-68. Toruń, Łódź: Colloquia Humaniorum.

Bloch, Natalia, ed. 2016. Wszyscy jesteśmy migrantami: (Od)zyskiwanie pamięci migracyjnej [We are all migrants: (Re)gained migration memory]. Poznań: Centrum Kultury ZAMEK.

Bloch, Natalia. 2017 "Projekt 'Wszyscy jesteśmy migrantami: (Od)zyskiwanie pamięci społecznej"" ["We are all migrants: (Re)gained migration memory": About the project]. Studia Migracyjne - Przegląd Polonijny 1 (163): 333-39.

Buchowski, Michał. 2010. “Antropologia społeczna Edmunda Leacha: Między funkcjonalizmem a strukturalizmem: Przedmowa do wydania polskiego" [Edmund Leach's social anthropology: Between functionalism and structuralism: Introduction to the Polish edition]. In Edmund Leach, Kultura i komunikowanie, VII-XXXIX. Warszawa: Wydawnictwo Naukowe PWN.

Buchowski, Michał. 2012. Etnologia polska: Historie i powinowactwa [Polish ethnology: Histories and affinities]. Poznań: Nauka i Innowacje.

Buliński, Tarzycjusz, and Mariusz Kairski. 2013. "Pytanie o teren w antropologii" [The question of the field in anthropology]. In Teren $w$ antropologii: Praktyka badawcza we współczesnej antropologii kulturowej, edited by Tarzycjusz Buliński and Mariusz Kairski, 9-24. Poznań: Wydawnictwo Naukowe UAM.

Buliński, Tarzycjusz, and Mariusz Kairski. 2015. "Etnografia jako proces: Wprowadzenie redakcyjne" [Ethnography as a Process: Editiorial]. Etnografia: Praktyki, teorie, doświadczenia 1: 5-8.

Cendrowski, Wojciech. 2016a. “Oczyszczanie 'zmarginalizowanej' przestrzeni: Wpływ rozbudowy szpitala na społeczność lokalną Starego Grunwaldu w Poznaniu” [Cleansing a "marginalized" space: The influence of hospital expansion on the local community of Stary Grunwald, Poznań] (Master's thesis). Poznań: Instytut Etnologii i Antropologii Kulturowej, Uniwersytet im. Adama Mickiewicza.

Cendrowski, Wojciech. 2016b. "Przestrzenne oczyszczenie na Starym Grunwaldzie: Przekazanie terenu na rzecz Uniwersytetu Medycznego im. Karola Marcinkowskiego" [A spatial cleansing in Stary Grunwald: Cession of land to Poznań University of Medical Sciences]. Etnologia.pl website. Accessed August 25, 2019. http://www. etnologia.pl/polska/teksty/przestrzenne-oczyszczenie-poznania-1.php

Dohnal, Wojciech. 2018. "Smutny jubileusz" [A sad jubilee]. Lud 102: 13-15.

Domańska, Ewa. 2013. "Humanistyka ekologiczna" [Ecological humanities]. Teksty Drugie 1-2 (139-140): 12-32. 


\section{Wojciech Cendrowski}

Dunn, Elizabeth. 2004. Privatizing Poland: Baby Food, Big Business, and the Remaking of Labor. Ithaca: Cornell University Press.

Hazan, Haim, and Esther Hertzog, eds. 2012. Serendipity in Anthropological Research: The Nomadic Turn. London, New York: Routledge.

Herzfeld, Michael. 2006. "Spatial Cleansing: Monumental Vacuity and the Idea of the West.” Journal of Material Culture 11 (1-2): 127-49.

Jasiewicz, Zbigniew. 2006. "Etnologia polska: Między etnografią a antropologią kulturową" [Polish ethnology: Between ethnography and cultural anthropology]. Nauka 2: 65-80.

Jasiewicz, Zbigniew. 2018. "Skąd, z czym i w jaki sposób etnografia/etnologia/antropologia pojawiła się przed 100 laty w odrodzonym państwie polskim?” [Whence, with what and how did ethnography/ethnology/anthropology emerge 100 years ago in the reborn Polish state?]. Lud 102: 41-83.

Kaczmarek, Łukasz. 2013. “Antropologiczna rewizyta terenowa: Etnografia zagrożona systemowo" [Anthropological fieldwork revisited: Ethnography and the systemic threat]. Zeszyty Etnologii Wrocławskiej 2 (19): 17-41.

Kaczmarek, Łukasz. 2014. "Teoria upudrowana: Wyobrażenia o etnografii a praktyki badawcze w antropologii polskiej" [Powdered theory: Ideas about ethnography and research practices in Polish anthropology]. Zeszyty Etnologii Wrocławskiej 2 (21): 115-42.

Kaczmarek, Łukasz. 2016. "Między survey research a obserwacją uczestniczącą: Rozdarcia metodologiczno-tożsamościowe w polskiej etnologii/antropologii" [Between survey research and participant observation: Identity and methodological ruptures in Polish ethnology / cultural anthropology in the 21st century]. Etnografia: Praktyki, teorie, doświadczenia 2: 123-36.

Kaczmarek, Łukasz, and Paweł Ładykowski. 2012. "Ethnographic Training in Borderland: Students Fieldwork, Serendipities, and Tight Limits of Polish University System." Cargo 10 (1-2): 99-117.

Posern-Zieliński, Aleksander. 1995. "Studia etniczne w polskiej etnologii po roku 1945: Ich uwarunkowania, konteksty i nurty" [Ethnic studies in post-1945 Polish ethnology: Settings, contexts, and currents]. Lud 78: 293-316.

Sokolewicz, Zofia. 2016. "Badania terenowe jako gwarancja empiryzmu w antropologii?" [Can fieldwork ensure anthropology's empiricism?]. Etnografia: Praktyki, teorie, doświadczenia 2: 137-43.

Wróblewski, Filip, and Aleksander Posern-Zieliński. 2017. "O drodze do antropologii, badaniach terenowych i etyce $\mathrm{z}$ Aleksandrem Posern-Zielińskim rozmawia Filip Wróblewski" [On the passage to anthropology, fieldwork and ethics: Aleksander Posern-Zieliński in conversation with Filip Wróblewski]. Etnografia: Praktyki, teorie, doświadczenia 3: 19-42. 


\section{Marzena Maciulewicz}

ORCID 0000-0002-7704-1412

University of Warsaw; Institute of Slavic Studies,

Polish Academy of Sciences, Warsaw

\section{IN SEARCH OF SCIENTIFIC IDENTITY: REFLECTIONS ON INTERCULTURAL PARTNERSHIP, FIELDWORK, AND RESEARCHER'S ENGAGEMENT}

The aim of this paper is to elaborate on different aspects and components of scientific identity and to identify the circumstances which may influence significantly the formation of a young researcher's scientific perspective. Although, professionally, I have never studied the concept of scientific or researcher's identity, I have decided to share my experience because I find the issue fundamental for every young researcher. The objective of this article is also to share the experience of fieldwork, intercultural cooperation, and engagement. 


\section{AN OVERVIEW OF COMPONENTS OF SCIENTIFIC IDENTITY}

Where can one find information about a researcher's identity? Some may read it between the lines of the mostly hidden, and underestimated, methodological reflexions based on field notes. In most cases, elements of the researcher's identity appear in the form of short biographical notes on the covers of books, profiles on social media or academic networks such as academia.edu or ResearchGate. Does a list of publications and projects on an academia.edu webpage or a professional account in services like linkedIn define who we are as scientists? One of the first results returned by one of Internet search engines after entering the phrase scientific identity was the link to the website issuing the ORCID numbers. Are the identities of researchers nowadays shaped by the researchers themselves or are they dominated by promotion, parameterization, evaluation and dissemination processes? Some may even claim that those who do not have such an account, specific number, scientific blog, or an article or even a book - published lately in an appropriate journal or publishing house do not exist, at least in the scientific world.

It seems that pondering scientific identity, one should take into consideration reflections on professional identity. Regarding the humanities, this subject is explored by psychology and pedagogy, with special focus on individual experience, and, to a lesser extent, by sociology, where it is analyzed mostly from institutional perspectives and through macrosocial determinants (Marciniak 2010). Many reflections on the researcher's identity, 
including the professional one, appear in anthropology and ethnology. There are also valuable interdisciplinary projects concentrated on the issue of the researcher's professional experience. Lukasz Marciniak, making an attempt to conceptualize professional identity within the scope of sociology, argues that professional identity should not be perceived as a fixed and unchanging state or a collection of specific characteristics but be analyzed based on the individual's changing behavior. This leads to the conclusion that professional identity has a processual, pragmatic and interactional character.

Authors of works devoted to the issue of researcher's identity (sometimes referred to as professional or scientific identity) emphasize its different components that include: research perspective, professional environment, research field, engagement, as well as the researcher's personal identity - and the relative importance of science within it.

One of the most common and dominant themes is the influence of personal identity on the quality of research work. Professional identity of any kind is constructed through reference and distinction processes on the intersection between three types of identity: the identity of the profession (borders, traditions, concepts of work), individual identity (how one is perceived by others) and subjective identity (how the individual perceives him- or herself) (Marciniak 2010, after Goffman 1963).

Some of the authors emphasize personal abilities, such as sensitivity, imagination, decisiveness, patience, interpretive and analytical ingenuity as well as the ability to adjust the 
research project to changing conditions (Rapior 2015), or specific personality traits: mental resilience, nonconformity, and ability to deal with stress and cognitive ambiguity (KośćRyżko 2013). Others focus on the borders between personal and professional identity of the researcher (Grzybowski 2016) or constant mutual influence of the researcher's private and professional life (Stanisz 2011).

In many studies, experienced researchers underline the importance of individual identity to the image formed by others (mostly by locals whom the researcher is studying) on the basis of age, gender, social and marital status, confession (Bielenin-Lenczowska 2011), social roles such as mother and 232 wife (Stanisz 2011), race and ethnic identity (Hammersley and Atkinson 2007). Members of the examined local community also have knowledge, experience and ideas about the culture from which the researcher comes (Kość-Ryżko 2013), therefore his or her biography (Bielenin-Lenczowska 2011) is undoubtedly important for informants. Many studies have been devoted to gender as a distinctive element of the researcher's identity (Golde 1986; Paczóska 2009; Bielenin-Lenczowska 2011), especially the status of the female researcher, her exclusion or inclusion in particular situations or events (Hammersley and Atkinson 2007).

Researchers also share dilemmas connected with their personal ideological or political views (Bielenin-Lenczowska 2011). Due to the nature of their work, they often have to suppress or hide their personal beliefs, ties, and political sympathies in the name of the "interaction ritual" (Hammersley 
and Atkinson 2007; Goffman 1972). Nevertheless, in some situations they cannot avoid making their position known, and have to face the consequences of entanglement through public statements and scientific articles (Grzybowski 2016). Due to the influence the researcher's image has on the process of data acquisition (Hammersley and Atkinson 2007), both the image itself and, by extension, the researcher's identity have to be carefully controlled.

Apart from personal character, researchers point also to the importance of external appearance and outfit (BieleninLenczowska 2011). The style of clothing may be an information carrier, it may suggest a similarity of the researcher to the hosts and/or release the researcher from an identity that would limit his or her field of activity. Therefore, researchers should not underestimate the importance of appearance and should decide themselves what impression they want to make, and influence their appearance accordingly (Hammersley and Atkinson 2007).

Another aspect of scientific identity is connected with research perspective. Identification with a particular discipline and sub-discipline results, in the first place, from the acquired knowledge (Bielenin-Lenczowska 2011), most notably from non-empirical knowledge (Schmidt 2011). Schmidt argues that the faculty and discipline we have chosen, the masters we have met and followed as well as the books we have read are all circumstances in which our researcher's identity is being created. He uses examples of disciplines connected with fieldwork to show how the choice of research perspective determines the 
attitude towards the field, respondents/informants and the goal of the research, as well as the level of the researcher's reflexivity (Schmidt 2011).

Another important aspect analyzed is the professional environment and the fact of being a member of a particular scientific institution. Identification with the discipline may be the result of being a part of a department or association (Stanisz 2011). Apart from being a member of a university or other research entity, it also matters if one is connected only with one institution or more, what status one has in this particular structure, whether or not it affords development perspectives and, last but not least, what the nature of the researcher's cooperation with the entity is and how much prestige it commands. Frequent interactions with the international scientific environment or membership in international organizations can even cause a researcher to identify him- or herself with the international professional milieu and feel a part of international culture (Wagner 2010).

Scientific identity depends also on the research field. The borderland, to take an example relevant to my own experience, implies a constellation of diverse cultural, linguistic and political orders, and therefore some authors underline difficulties of researching cultural borderlands (Grzybowski 2016; Bielenin-Lenczowska 2011). Organizing fieldwork in a borderland demands at least a duplication of effort in terms of contact with local inhabitants and institutions, cooperation with the representatives of different groups as well as one's own engagement in the reality observed. Commentators also emphasize the consequences of tackling sensitive problems, 
such as illegal activities, acts of discrimination and violence, international conflicts, murders, ethnic cleansing (Grzybowski 2016), taboos, and other minefields (Kuźma 2013 after Albera 2001). One should also keep in mind the difficulties occurring in a field where the researcher is manipulated, becomes an object of local intrigues, faces institutional obstacles and official hurdles, or simply when his or her previous experience is being challenged (Kuźma 2013).

One of the topics extremely important for this analysis is the engagement of the researcher, in its diverse aspects: emotional, social, political, etc. A related problem is the level of engagement in research of the local inhabitants, their importance for as well as their influence on the process and results of research. Does the researcher contact locals only during the interviews or observation, or does he or she understand and act on the need to work with not on (Bielenin-Lenczowska 2011 after Pink 2000)? Another important issue are the limits of cultural relativism, and how one should react to acts of violence, or elements of social, cultural and political life as well as personal life which are in conflict with one's own culture (BieleninLenczowska 2011; Rapior 2015; Stanisz 2011; Kość-Ryżko 2013). The same concerns engagement in situations perceived in categories of injustice (Kość-Ryżko 2013). The last related question is whether the researcher understands the burden of entanglement through public statements and scientific articles (Grzybowski 2016) and to what extent one has the right, or obligation, to engage in the studied environment on the level of social or political actions. Karolina Bielenin-Lenczowska 
argues that it is important to use the opportunity of having a voice to present conclusions alternative to the dominant discourse, especially when the latter results in discrimination. Bielenin-Lenczowska herself opposes the negative image of Albanians in Macedonia by presenting examples of peaceful coexistence (Bielenin-Lenczowska 2009, 2011).

Finally, an important aspect to consider is the influence exerted on the person of the researcher by his or her role. Scientific identity may become a dominant element of overall identity when the researcher sees him- or herself mainly, or only, through the prism of work. On the one hand, it proves the researcher's strong scientific identity (Wagner 2010), but on the other hand, it may become an obstacle to further development. A lack of balance between personal and professional identity as well as an irrational belief in the profoundness of one's professional role have the potential of causing professional burnout (Kość-Ryżko 2013).

Many aspects of researcher's experience have already been covered; nevertheless, there still is, and probably will always be, the need to elaborate on them. In this paper, I would like to take a close look at the elements potentially shaping identity and at identity-creating activities (Marciniak 2010). In order to do so, I will make an attempt to follow my own progress and to identify actions and circumstances which influence the process of shaping scientific identity, taking into consideration the dilemma best summarized by two questions: what kind of researcher am I? as well as what kind of researcher am I not? Alongside my own experience, one of my reference points 
will be the experiences of my fellow young researchers and co-workers.

Obviously, other components of researcher's identity which have influence on his or her work are extremely important but due to this paper's limits, I will focus on components strictly connected with professional development. The aim of this analysis is to elaborate on the strategies researchers apply when seeking their own perspective which will enable them to properly tackle the particular research problem without losing sight of its specificity and uniqueness in the process. On the one hand, an attempt to put him- or herself in the position of the Other ultimately leads to the dispersion of the researcher's own identity and the obliteration of research goals; on the other hand, a priori subjugation of the research field to our own categories may in turn lead to a loss of contact with reality (Walczak 2009). The researcher, functioning between different categorization systems, needs to somehow cope with this problem of otherness.

Łukasz Marciniak has identified a number of fundamental identity-shaping actions: professional socialization (the process of adapting to new professional environment), status passages (associated with the development of professional career, promotions and degradations), or change of professional practice (for instance, as a result of technological advancements) (Marciniak 2010). His proposal remains another reference point for this paper: my experiences of interdisciplinary studies, mobility, fieldwork and multicultural cooperation can all be interpreted in these terms. 


\section{BACKGROUND: INTERDISCIPLINARY PERSPECTIVE}

My participation in the PhD seminar "Searching for Identity: Global Challenges, Local Traditions," like the choice of the PhD program and the subject of the thesis, was not accidental. The final decision as to the subject of the doctoral dissertation was preceded by a long period of empirical research and consultations conducted at home and abroad (mostly during my PhD studies). The research topic proposed is at the crossing point of my interests, language skills and knowledge, and the results of the preliminary research carried out during my doctoral studies in the area being the subject of the dissertation. This preliminary exploration had an impact on the choice of working methods, which included the use of diversified research material on top of conducting my own empirical research.

The choice of this particular PhD program, too, was preceded by a long period of studying the available offers and admission rules in different faculties and universities. After experiencing studies in different fields (including cultural studies and international relations) and cooperation with various academic units, my priority was to find a place where research independence and scientific self-consciousness were considered as an advantage, or at least tolerated. As a young researcher not strictly connected with one methodological perspective, who was still in search of her own scientific identity, I was looking for inspiration from students and professors, opportunities for mobility, support for independent research projects (perceived at times as too bold 
or hazardous) and, last but not least, the possibility to develop my own interdisciplinary path.

Not without significance were also the fieldwork projects which I had carried out abroad before working on my $\mathrm{PhD}$ thesis. My first independent scientific experience was research on the phenomenon of carnival in Rijeka, conducted in 2011 with a group of five other students of cultural studies. The topic seemed relatively noncontroversial but it had me face, for the first time, huge organizational challenges and those resulting from editorial process. Then came fieldwork in Pristina and Mitrovica (2015) in a group of 7 students from my faculty. ${ }^{1}$ My last research experience before conducting the research for $\mathrm{PhD}$ thesis was a project realized in Nis (2016) with a group of local sociology students. Entitled "A Contribution to the Interpretation of Urban Space in Serbia: Inhabitants' Attitudes Towards the Phenomenon of Illegal Development," the project concerned a quite sensitive topic; it also had me fulfilling a new role as the coordinator of a research group consisting of 17 local students. It was my first project organized in cooperation with foreign partners, who, apart from the research group, included also the local academic staff.

The main research challenge of my $\mathrm{PhD}$ was to examine in which aspects and to what extent one medium-sized post-conflict city was / could be perceived as a divided city. The aim of the research was to provide a multifaceted image of

\footnotetext{
${ }^{1}$ The outcome of this research was, among other results, the publication of Kosowo. Spoteczeństwo - kultura - polityka, K. Gerula, Ł. Karczewski, A. Koziej, M. Maciulewicz, M. Mudel, M. Smoter, Warszawa 2015.
} 
Mitrovica, ${ }^{2}$ an image that would not be limited to one national perspective. In most of the studies, one can find the information about the Ibar River marking the unofficial border between the de facto Albanian Kosovo and the predominantly Serbian North Kosovo. ${ }^{3}$ Whereas it is true that Mitrovica nowadays is home predominantly to these two communities, they are not the only ones. According to available data, the city is inhabited by Albanians, the Ashkali, Bosnians, the Gorani, Montenegrins, the Roma, Serbs and Turks, several sources mention also the Egyptians (either as a separate group or as a part of the RAE community: Roma, Ashkali and Egyptians), with foreigners on top of that. The domination of the ethnic/national dimension in the narratives about the divisions in so-called divided cities (not only Mitrovica but also other places in the region and beyond) was and undoubtedly still remains justified, and the thesis did not aim at challenging it. Nevertheless, one cannot underestimate the importance of other factors which shape the urban landscape in the context of disintegration and integration processes. The same concerns also communities, whose realities are more complex and less hermetic than it may seem at first glance. What is more, they constantly redefine and shape their identities in line with political circumstances and as a result of interaction with other groups. The Serbian and Albanian national identities are also not as stable and homogeneous as

\footnotetext{
${ }^{2}$ Mitrovica is a city located in the northern part of Kosovo, nowadays perceived mostly as a divided city, not only abroad but also by locals.

${ }^{3}$ Zubni Potok, Zvečan and Leposavić municipal authorities maintain Serbian government structures and use Serbian state emblems.
} 
is commonly claimed, a fact that, I believe, has been proven in my thesis.

\section{A DIFFICULT FIELD ${ }^{4}$}

During my previous fieldwork and studies, I had noticed many problems which may be universal, but were certainly characteristic of my main field of studies. It was obvious that I had to take them into consideration while preparing for the fieldwork related with my $\mathrm{PhD}$ thesis.

The most striking observation regarding the literature of the topic is that many scientific works use stark generalization, or present a far too simple picture of a very complex reality. It is still difficult to determine with certainty the causes for this phenomenon, and in any case, the reasons are probably numerous and diverse, but I have noticed that in many instances it is connected with negligence regarding the sources. Works are based on sources that are limited in terms of their kinds and languages, and those studies which feature field materials at all, do so in a limited, manipulative, or selective manner. ${ }^{5}$ In some instances, it was also the result of a biased perspective resulting from connection with just one research field.

Secondly, in many cases researchers had to face problems connected with the recent armed conflict in this territory.

\footnotetext{
${ }^{4}$ The term "field" is used in different context and is not strictly connected with particular region/territory/space. On conceptualisations of the field in cultural research, see: Buliński and Kairski 2011.

${ }^{5}$ I already identified those problems during my previous research in this area. See: Maciulewicz 2015.
} 
The research carried out in a post-conflict area is inseparably linked to a strong intensification of basic fieldwork problems and to emergence of unexpected complications. What is extremely important, post-conflict societies are incredulous and suspicious. Therefore, they are not always willing to cooperate, as either private individuals or representatives of particular entities. Researchers may struggle with many problems resulting from obstructions in the work of institutions, such as a lack of statistical data or of access to the sources in archives and libraries.

Obstacles characteristic of the region are also linked with the perception of particular professions, and of their foreign representatives. For instance, a historian (or any individual dealing 242 with history) is perceived as important, or rather useful, making it a "front-line profession" in a political sense (Czekalski 2013). Yet the status of a foreign historian is made more complicated by the fact that he or (even worse!) she is seen as obviously unable to understand local history, and therefore in need of assistance from local "interpreters." Consequently, foreign researchers deal with manipulated scientific discourse, especially in regard to relatively recent conflicts or sensitive events from the past (Grzybowski 2016; Czekalski 2013).

Tadeusz Czekalski mentions the condition of archives, which are not well maintained, without original documents and artefacts, and may prove only a waste of time, especially during short-term research, not least so because of various unexpected circumstances, like power shortages (Czekalski 2013). Very characteristic for this region and essential for most research is also the importance of oral history as testimony to and evidence 
of the past (Halili 2012), and disbelief in the reliability of any document drawn up by officials (Czekalski 2013, 152). Among important characteristics one cannot also underestimate the focus on medieval history and its extremely close connection with the modern times (Czekalski 2013, 152-53).

Many dilemmas also regard language: the importance of command of the local language and translation difficulties (Ćwiek-Rogalska 2017), transcription of the responses received and their eventual incorporation into the final research text (Kudela-Świątek 2012), as well as the engagement of the translator on every stage of research. Other linguistic problems resulted also from the region's character of a cultural and most notably linguistic borderland, which implies confrontation with complex multilingual identities (Bielenin-Lenczowska 2011).

One cannot also omit many problematic organizational aspects of fieldwork, limited as it is by time, space, and financial resources. An inexperienced researcher might not suspect how much depends on the weather, "local calendar," and current political situation. Extremely important, especially in cases of research abroad or in borderlands, is the calendar of local celebrations. For researchers who were raised in a Christian cultural contexts and are planning to conduct research, for instance, in a Muslim community, it is important to prepare in terms of organization, proper behavior and maybe even outfit, depending on the particular project.

Last but not least, it is crucial to mention once again the issue of the project's influence on the studied reality (community). Ethical aspects of a researcher's attitude towards 


\section{the studied environment and consequently towards their pro-} fessional environment have already been covered in many academic textbooks (cf. Babbie 2007; Hammersley and Atkinson 2007). Nevertheless, since fieldwork remains a kind of initiation (Bielenin-Lenczowska 2011), each and every researcher learns in practice how not to harm the local community and not to "burn" the field for other researchers.

Throughout the whole period of my PhD studies, research stays and eventually empirical research, I was trying to mitigate those obstacles. Taking into consideration all the circumstances described above, I was trying to find answers to many methodological, ethical and theoretical questions regarding my main research problem. How to study divisions within a society in a post-conflict territory? What was missing, which neglected aspect should be taken into account? How to achieve high diversity of responses and opinions so as to present accurately this undoubtedly complex local universe? How and to what extent should the local people be included in my research? How to shape and implement the anthropological imagination when confronting the Other? ${ }^{6}$ How to confront the challenge of being the Other? How to deal with the gap between the categorization of the world made by the researcher and one made by members of local community?

\footnotetext{
${ }^{6}$ Anthropological imagination is based on the possibility of understanding yourself by understanding others; being aware that any particular lifestyle is only one of an unlimited number of possibilities, anthropology can help make the exotic something known, which might enable fresh and deeper ways of thinking. Anthropological imagination moves beyond time-space barriers and concerns all disciplines of the humanities. See: Mencwel 2006.
} 


\section{MILESTONES IN SHAPING SCIENTIFIC IDENTITY}

The process of identity-shaping is a constellation of circumstances and influences which interact with one another in a way that is not easy to fathom, rather than a series of events which happen in cause-and-effect sequences. Dynamic character, processuality, intangibility are among the most important characteristics of identity-shaping. In what follows, I make an attempt to identify circumstances and elements which influence the ongoing process of shaping scientific identity and to describe them in relation to selected categories. Obviously, the proposed categorization is artificial and created with the purpose of organizing thought, and so overlapping between the categories is inevitable. In my perspective, the identity-creating activities that particularly warrant being taken into consideration are: the experience of staying abroad, partnership in research, interdisciplinary approach, and fieldwork.

\section{MOBILITY}

It has been proven that one of the factors which may significantly influence the identity of a young researcher is mobility: long-term stays (scholarships), short-term stays (conferences, preliminary research), research abroad, and other similar activities. In the case of more experienced researchers - even several-year contracts. As a result of socio-political changes after 1989, researchers have been engaged in intense mobility and mobility itself has changed character from almost exclusively 
individual to one within an institutional system of networks (Wagner 2010).

I have experienced all possible forms of mobility available to students using different scholarship programs in the region and beyond. Actually, I have spent most of my $\mathrm{PhD}$ studies abroad at different departments and faculties of numerous foreign universities: Department of Sociology (Faculty of Philosophy, University of Nis), Department of History (University of Belgrade), Faculty of Philology (University of Prishtina Hasan Prishtina), as well as Faculty of Philosophy in Mitrovica (University of Pristina with temporary seat in Kosovska Mitrovica ${ }^{7}$ ).

Mobility and the experience of work in international environment has many advantages, such as contact with different cultural and linguistic environments, and diverse research perspectives and approaches as well as narratives. I would even venture a hypothesis that mobility (like fieldwork) has the role of an identity-shaping accelerator. The young researcher, confronted with the Other in every possible aspect, is pushed to face many existential questions regarding, among other things, his or her scientific identity. Besides the undeniable benefits of studying at a foreign university, like the acquired knowledge and language skills, such form of mobility creates an opportunity to experience the feeling of otherness, to rethink one's own institutional affiliation and the system of higher education in

${ }^{7}$ A public university in Mitrovica (Univerzitet u Prištini Kosovska Mitrovica) that emerged after the disestablishment of the University of Pristina (1969-1999) as a result of the conflict in Kosovo in the 1990s. 
general, to observe oneself in different circumstances, and to evaluate critically one's own abilities and knowledge.

Firstly, being a foreigner, temporary "citizen" of another country and foreign student enables the researcher to experience a sense of being the stranger on different levels. The "temporary citizen" status engenders a specific relation with different offices of public service, such as banks, the police, etc. The foreigner experiences his or her own otherness within his or her immediate neighborhood and in everyday life: at the shop, the gym or in the cafeteria. The status of foreign student is felt extremely acutely in places where student exchanges and mobility are not that common and where he or she may be more frequently identified as "the foreigner" or by nationality than by name.

Secondly, at the other university, the exchange student represents his or her own institution, and it is possible for the sense of identification or responsibility towards his or her own academia to become stronger than at home, where he or she is not so visible and does not have to confront him- or herself with other academic structures. The foreign student is forced to build from the scratch relations with academic staff and students, which might be a transformative experience, especially for individuals who have already worked out a status in their own environment. Discussions, consultations and cooperation with the academic staff as well as students may be uplifting or discouraging, but they exert an undeniable influence on the development of the researcher. Such re-evaluation based on the confrontation of at least two academic systems may result 
in a critical approach towards one's own professional environment and system of higher education.

Moreover, academic mobility can result in a transformation of identity, not only professional but even personal one. Elaborating on the results of her research on students who experienced working abroad or in international teams, Izabela Wagner (Wagner 2010) describes changes in both those aspects. In terms of personal identity and traits of character, the students seems to gain self-confidence and courage. They also assess ambition as an obstacle to career in Poland juxtaposing it with the foreign academic creativity and initiative, which may be perceived at home as excessive boldness. Evaluating the systems of higher education, they point to differences in priorities on the part of professors, in the functioning of systems and networks regulating the labor market in the academic environment, in the nature of cooperation between researchers, and in communication between professors or experienced academics and students or young researchers. Wagner's study has demonstrated the creation of a new identity, characterized by a modified perception of hierarchy and transborder mobility and a rather negative attitude towards the previous identity. Participation in mobility programs may develop the young researcher's capacity for critical and independent thinking.

Mobility and research stays abroad are very challenging, and in some cases decisive, for young researcher, even though they are considered a time off by malignant observers. Taking into account all the above-mentioned factors, the issue of the student's relation with their Alma Mater cannot be omitted. 
In my case, apart from the contact with my tutor, participation in the seminar "Searching for Identity: Global Challenges, Local Traditions" remained one of the factors which facilitated the process of completing my $\mathrm{PhD}$. The possibility to participate in the seminars and lectures at the Faculty of "Artes Liberales" enabled me to benefit simultaneously from the stay abroad and the education offer "at home." I could stay in touch with my faculty, participate in classes in my mother tongue, be inspired by the professors' work, and become aware of the obstacles that my colleagues faced.

Paradoxically, this experience convinced me about the possibility of being an international researcher "at home." International laboratories and research teams can be created in any place as long as specific ethos and organization of work is maintained.

\section{THE IDEA OF PARTNERSHIP}

\section{IN CULTURAL RESEARCH}

It seems obvious that the participation of local inhabitants in research is inevitable. Not only do they offer invaluable organizational assistance during the whole stay at the research site, but they are also very helpful in the research process itself. They know local languages, their homes and everyday life are a part of the local landscape, they are familiar with local unwritten rules as well as characteristics of the local community. Depending on the status and identity of the local inhabitant, he or she may help gain better access to local institutions, more closed communities or less available places. 
The local inhabitants and communities should also benefit in one way or another from the mutual cooperation. Some of them value the very interest on the part of a foreign researcher in their reality, history, tradition, language, etc. Others benefit from cooperation with the academic unit the foreigner represents, his or her company, or the opportunity to communicate in a foreign language. There are also locals who take part in research to contribute to the development of their community by learning new skills as well as establishing grounds for further cooperation.

Local inhabitants were engaged in my research in all possible roles, including as independent interviewers, consultants, and guides to everyday life. Contact with local people and institutions as well as participation in local events were integral elements of my everyday practice.

One such event took place in 2017. In June, I was awarded a small UN Mission to Kosovo grant within the Youth4Youth Program to carry out an inter-ethnic project. I implemented this grant in September by organizing a workshop titled "Enjoying Empirical Research in an International Working Team! Basics of Fieldwork Research in Practice - Mitrovica 2017."

The workshop and the research it entailed remained a part of my scientific study of Mitrovica perceived through the category of a divided city. The objective of the project was to enable local young people to experience working in an international team, to gain theoretical and practical knowledge of empirical research as well as to build networks so as to integrate and improve their communication with potential future co-workers, neighbors, or simply friends. The more general aim of this initiative was 
twofold. First, using my knowledge and expertise, I wanted to contribute to the peace-building process by supporting young potential local leaders. Second, I hoped that the experience of the workshop would allow me to achieve better outcomes of my PhD research. Simultaneously, I intended to establish contacts with local students and activists to build networks which would contribute not only to my personal career but also to the cooperation between local leaders and academic institutions as well as between non-governmental organizations in the region and beyond. Taking into consideration the current situation in Mitrovica, I was sure that there was a need to create two research teams operating in the northern and in the southern part of the city. Nevertheless, the UN team convinced me to make an attempt to organize one workshop for a mixed group and create a project team which would include also local people. After two months of intense preparation during the hottest months, the workshop took place in the Diakonie Youth Center ${ }^{8}$ in Mitrovica, which I consider one of most suitable places, if not the only place, in Mitrovica where such an multicultural event can be realized.

The participants included young people, students and NGO activists from the region (not necessarily from Mitrovica) who were able to communicate in English and spoke fluent Serbian and/or Albanian. I wanted to cooperate with people from different communities, of different genders, social backgrounds, beliefs and views who were eligible for the project, which

\footnotetext{
${ }^{8}$ The youth center is a project of Diakonie Kosovo inaugurated on September 19, 2013. It is located on the Ibar River next to Mitrovica's main bridge.
} 
meant that they could communicate, but also were open to cooperating and learning. Eventually, after a long recruitment process, 18 participants were selected to take part in the activity, 11 females and 7 males, students of sociology, psychology, law, journalism, and political studies. Most of the participants were either from Mitrovica or from Pristina. For some this was their first visit to Mitrovica, there were also participants who lived in Mitrovica but met other inhabitants from Mitrovica for the first time during the workshop.

The workshop's program included theoretical introduction and practical exercises in social research methods, such as observation, conducting interviews, and using questionnaires. Participants engaged in a pilot research (in the roles of respondents and interviewers) and gained practical knowledge of presenting themselves and their scientific project to respondents. The students also learnt how to create their own research projects and where they should apply for financial support for their initiatives. Last but not least, there was also a space to discuss the different images and representations of Mitrovica, as well as to enjoy each other's company during integration exercises.

I led most of the activities myself, but some of the participants were also engaged in preparing exercises or lectures. Those who completed the workshop with positive outcomes and were open to further cooperation were engaged in my further research as independent interviewers. 


\section{PARTNERSHIP IN CULTURAL RESEARCH IN PRACTICE}

The quantitative research on the local inhabitants' attitudes towards different aspects of the functioning of the city was carried out in Mitrovica in November 2017. Regardless of some obstacles, more than 300 structured interviews were conducted by local interviewers. The research team consisted of 22 independent interviewers from different communities (Albanian, Bosniak, Roma and Serbian) and different towns (Mitrovica, Pristina and Nis), who successfully completed the recruitment process. Like the participants of the workshop, the interviewers were young people, students and NGO activists, who spoke fluent Serbian and/or Albanian. They also had to have experience in empirical research and/or be familiar with the methodology of social science; most of them were able to communicate in English and other foreign languages. The researchers' engagement in the fieldwork included several additional activities, such as participation in a fieldwork preparation course, critical analysis of the prepared questionnaire, participation in quantitative research with a sample group of respondents in accordance with provided instructions, and evaluation of the research.

Most of the interviewers completed two trainings: the above-mentioned one-week free preparatory course covering the basics of empirical research in September 2017 and a oneday training before the research in Mitrovica regarding this particular research project. 
Since I did not have any serious financial support to organize this research and was myself living on a rather modest scholarship, I could not offer my co-workers any salary (which was a common practice in this cultural context) but only my knowledge and experience. Even though it was hard to work in such conditions and the situation required more effort to find proper interviewers who would agree to work for free, in retrospect I can evaluate these circumstances positively. The reason is very simple: as a result, I managed to engage in my project young, intelligent and ambitious people who were interested in getting knowledge and experience and developing further cooperation, and who were motivated by their role as interviewers and 254 members of a multicultural team rather than by money. All in all, the participants of the research were promised to receive the following benefits: participation in a free preparatory course on qualitative research methods, certificate of completion of the course and participation in the research (issued by the University of Warsaw), free working materials (including questionnaires), reimbursement of travel costs to and from the place of the research, refreshments and snacks during the activity, and for those who fulfilled their obligations - the possibility to apply for an intercultural workshop organized in 2018 at the University of Warsaw (fully or partly financed by the organizers, depending on the then pending outcomes of funding applications).

I had to coordinate the work of two big groups, therefore I decided to prepare two trainings in both parts of the city. I came to Mitrovica two days before the planned research, with many concerns and doubts: there was no certainty if I would have 
a space to meet with interviewers and conduct the training, or even if my accommodation was arranged. In situations like these, I had to trust my local co-workers, while expecting the unexpected. During the training, too, the assistance of local partners was invaluable in translating and encouraging capable people to participate in research as well as in terms of my cooperators' knowledge of the city's topography. Unfortunately, some of the participants were absent from both preparatory trainings. Therefore, I had to organize additional meetings with those who did not participate in the training, which included making trips to Pristina.

The training included information about the goal of the research and the obligations of and benefits for the interviewers, an analysis of the prepared questionnaire, a short presentation on the characteristics of the structured interview and the selfcompletion questionnaire, as well as two practical exercises. Using the research knowledge they had just gained, the participants were practicing introductory statements and the situation of the interview in the roles of both the respondent and the interviewer. After the training, each of the interviewers received Guidelines for Interviewers (prepared for this particular research) and detailed instructions regarding the particular part of the city in which he or she would work.

The structured interviews were conducted according to a prepared questionnaire. Three language versions of the questionnaire were prepared for the purposes of the research and $\mathrm{PhD}$ thesis (the English version was not used during the empirical research). All three versions of the questionnaire were then 
verified during the pilot research, organized among the young population of the city in September 2017. All interviewers were obligated to deliver the final report after completing their part of research. For reasons of security and in order to avoid any mistakes or misunderstandings, I was in daily contact with all the interviewers. Some needed support when many people were refusing to participate in the research, others had problems resulting from bad weather conditions or interruptions in electricity supply. To evaluate their work properly and clarify any doubts, after the completion of the research, apart from a joint session, I organized separate meetings with each of the interviewers, including, again, trips to Pristina. Every meeting lasted a minimum of half an hour (but in most cases more), during which I checked carefully every questionnaire and listened to every interviewer's impressions from the field. The results exceeded all of my expectations and only strengthened my conviction that a great research team had been created.

I continued the fieldwork for my thesis in April and June 2017. In terms of qualitative research, I conducted semistructured interviews, mostly during those two stays. Thanks to numerous previous stays and preliminary research, the research site was no longer unknown ground, and my presence was not surprising for the many people that I had already met. In order to receive diverse responses and opinions, a group of respondents was selected carefully with the assistance of local co-workers. Nevertheless, I was trying to be as independent as possible when it came to the organization of everyday life, moving around the city and in neighboring locations as well as arranging and 
conducting interviews. I share the belief that to conduct valuable fieldwork, it is crucial to be able to communicate with local people. Local interlocutors should be able to use the language they feel most comfortable in. Interviews were conducted in three languages (Albanian, English and Serbian), depending on the respondents' wishes, with or without the assistance of a local translator. Most were registered using a voice recorder. Even though I had already conducted many interviews as well as unofficial conversations in foreign languages, it was one of the most demanding experiences in my research career. Additional information regarding the interview situation, results of participant observation, and methodological remarks were carefully noted down as soon as possible. This article as well as many other papers and texts could not have been written if I had not kept a detailed research diary throughout my stay abroad. Research notes enabled me to save from oblivion valuable reflections, mark the progress of the project as well as remain emotionally stable during the period of research.

\section{PARTNERSHIP AT HOME}

Eventually, our common Mitrovica project was completed by "Theory in Practice: International Workshop for Young Researchers Working in Intercultural Environment," organized in September 2018 at the University of Warsaw by the Faculty of "Artes Liberales." The workshop was, among other things, a continuation of activities aimed at increasing the potential of young researchers in the humanities, strengthening their 
intercultural communication skills and integrating Polish university students with their foreign colleagues. The previous stages of my $\mathrm{PhD}$ project were certainly an inspiration for such a project, which included not only University of Warsaw students but also participants of my former research team. The workshop was addressed to BA, MA and PhD students of the University of Warsaw representing various research and teaching perspectives as well as scientific fields (anthropology, ethnology, linguistics, history, cultural studies, Slavic studies, sociology).

The lecturers invited to conduct the workshop were scholars with significant academic achievements and didactic experience, distinguished by their activity in the international arena and representing different faculties of the University of Warsaw and foreign universities. The project presented a unique opportunity to exchange experiences between lecturers, as well as between the academic staff and students. In the institutional dimension, it aimed at strengthening the research potential of the academic centers involved in its implementation and at fostering cooperation between individual units of the University of Warsaw and other universities. Finally, the project was a response to the current problems of intercultural relations and was implemented with the aim of opening the field for a debate on the role of non-governmental organizations and the university in building and strengthening intercultural relations, as well as the issue of cooperation between the university and other entities.

During the debate titled "Engaged Humanities: NGOs and the University," the participants of the workshop raised the 
issue of the relations between academic education and practical skills in different countries. One of our guests, representing the Office for Innovation in the Academic Space at the University of Warsaw, brought up the questions of discrimination in the academic environment, the third mission of the university, and coming up with an academic offer which would be appealing to the foreign student. The meaning of the researcher's engagement was also touched upon during the meetings devoted to cultural studies in the urban space ("Research as Participation: Urban Planning and Politics") and to ethnographic research ("Doing Ethnography among and Writing about 'the Others': Challenges of Participant Observation"). Some of the classes were designed to develop the attendees' sensitivity to otherness, for instance the seminar on the importance of language in cultural research or two meetings dealing with challenges of the biographical interview.

Since the workshop formula was dominant during all above-mentioned meetings, participants gained also practical skills which they could freely develop of their own initiative. The workshop included meetings that were designed as introductory and had a strictly practical character: "Quantitative Analysis: The SPSS Software in Social Research"; "Elements of a Scientific Project"; "Scholarships, Exchange Programs and Support for Scientific Projects" and "Creative Thinking: Crisis Management."

The evaluation process included the participants' presentations of their scientific projects and the final report of the event based on evaluation questionnaires filled out by the participants using the notes they had taken during the whole period of 
the workshop. One of the foreign participants described the experience of the workshop with these words:

Workshops work best when people are engaged, motivated and working as a team. There may well be healthy discussions and disagreements, but when these are met with an ethos of collaboration, all parties can work their way through them. This is what I found in the workshop and I wouldn't change anything.

Even though the workshop took place in Warsaw, organizing this international event was no less demanding and exhausting than my activities in the field. It was obvious from the very beginning that some participants would need to apply for visas to travel to Poland, but many additional complications and unexpected circumstances made that process extremely difficult. What is more, the stay of foreign guest was arranged with very limited financial support and was accompanied by constant struggles to find transport and accommodation offers which would be relatively low-cost and at the same time would meet basic expectations. I am absolutely convinced that without the help of the Faculty, the workshop would not have taken place in such formula.

Another conclusion is therefore that the sense of support given by an institution is also one of the important circumstances which influence the shaping of a young researcher's identity. I truly appreciate the institutional support I received from the very beginning of my project from the Dean of the Faculty of "Artes Liberales," and the instructional and organizational support of the Head of my doctoral program and at the same time the coordinator of the seminar "Searching for Identity: Global Challenges, Local Traditions." I am grateful 
to my tutor for accepting my research proposal, as well as to other members of the academic staff and administration of the Faculty for their assistance in many different situations. Being perceived and treated as a bothersome supplicant in a public office or a potential additional problem may become an obstacle to a young researcher's creativity and initiative.

Little space has been dedicated in this paper to everyday struggles for financial support, scholarships and acceptable accommodation conditions, to health problems, demanding weather conditions, shortages of water, electricity and Internet connectivity, or problems with transport, nutrition and the organization of seemingly simple everyday activities, like laundry. To keep the picture balanced, it is worth to emphasize that this paper was also not dedicated to many positive sides of cultural research in this region, such as the tasty and fragrant local food, the sun, friendly and open people, the priceless experience of being a guest, and indescribable space that this experience opens up for thoughts and free thinking. The reason for this omission is simple, words cannot reflect the experience of life in a different cultural context. Such is the burden and at the same time the privilege for those who decide to start the journey that is conducting one's own research.

\section{CONCLUSION}

All that was said above leads to several general conclusions. The search for scientific identity is never over, nor should it ever be. Scientific identity is a dynamic and intangible phenomenon 
of a processual, pragmatic and interactional character. It has a complex and fluid structure which is being shaped through ongoing interactions of circumstances and influences rather than by events which happen in cause-and-effect sequences. Therefore, studies on researcher's identity include different concepts related to and components of professional and scientific identities.

Scientific identity is inseparably connected with other components of individual identity, such as personal identity, research perspective, professional environment, research field, and the importance of scientific identity itself in the constellation of individual identity. As the researcher explores identity issues 262 among representatives of other cultural and ethnic groups, his or her own identity is constantly developing and maturing (Kość-Ryżko 2013). Even though in this paper I have striven to elaborate on professional aspects of scientific identity, the influence of identity-creating activities on personal identity and vice versa is undeniable. The experience of living in a divided city and, at least to an extent, becoming a part of this reality, with its memory of recent violence and strategies of coexistence, has its consequences also for the researcher's identity. I suppose that circumstances such as restrictions on free movement, changeable conditions of living and working, and witnessing different behaviors, for instance among neighbors, have given new semantic depth and weight to my perception of words like "tolerance" or "violence."

Based on my personal experience, I have presented an overview of the circumstances which have the potential of being factors 
that shape scietific identity. The importance of interdisciplinary experience, student/researcher mobility, inter-cultural cooperation as well as the opportunity to realize one's own initiative and get involved in team work should not be underestimated in this regard. The project "Searching for Identity" undoubtedly created such circumstances: it gathered $\mathrm{PhD}$ students and professors from diverse research fields and different cultural backgrounds, with the seminar formula enabling the meetings to include students who worked abroad. The end of the seminar did not put a stop to mutual assistance and cooperation between its now former participants. On the contrary, the program has found continuation in further initiatives and common projects.

\section{REFERENCES}

Albera, Dionigi. 2001. Terrains minés [Minefields]. Ethnologie Française 37 (2): 5-13. Babbie, Earl. 2007. The Basics of Social Research. Belmont: Wadsworth Publishing. Bielenin-Lenczowska, Karolina, ed. 2009. Sąsiedztwo w obliczu konfliktu: Relacje spoteczne i etniczne w zachodniej Macedonii - refleksje antropologiczne [Neighborhood in the face of conflict: Social and ethnic relations in western Macedonia - anthropological reflections]. Warszawa: DiG.

Bielenin-Lenczowska, Karolina. 2011. "Gdzie jest mój teren i kim w nim jestem? Kilka pytań w związku z terenem, wiedzą i etyką antropologa" [Where is my field and who am I there? Several questions related to the anthropologist's field, knowledge and ethics]. In Teren w antropologii: Praktyka badawcza we wspótczesnej antropologii kulturowej, edited by Tarzycjusz Buliński and Mariusz Kairski, 151-68. Poznań: Wydawnictwo Naukowe UAM

Bielenin-Lenczowska, Karolina. 2013. "Tematy trudne, trudne badania: O wielostanowiskowej etnografii wśród macedońskich Muzułmanów (Torbeszów) w Macedonii i we Włoszech" [Difficult topics, difficult research: On multi-sited ethnography among the Macedonian Muslims (the Torbeši) in Macedonia and Italy]. In Tematy trudne: Sytuacje badawcze, edited by Inga B. Kuźma, 49-63. Łódź: Wydawnictwo UŁ.

Buliński, Tarzycjusz, and Mariusz Kairski, eds. 2011. Teren w antropologii: Praktyka badawcza we wspótczesnej antropologii kulturowej. Poznań: Wydawnictwo Naukowe UAM. 


\section{Marzena Maciulewicz}

Ćwiek-Rogalska, Karolina. 2017. Zapamiętane w krajobrazie: Krajobraz kulturowy czesko-niemieckiego pogranicza w czasach przemian [Memorized in landscape: The cultural landscape of the Czech-German borderland in a time of change]. Warszawa: Scholar.

Czekalski, Tadeusz. 2013. "Perypetie historyka - o specyfice badań nad przeszłością w krajach bałkańskich" [A historian's adventures - on peculiarities of studying the past in the Balkan states]. In Tematy trudne: Sytuacje badawcze, edited by Inga B. Kuźma, 143-54. Łódź: Wydawnictwo UŁ.

Golde, Peggy, ed. 1986. Women in the Field: Anthropological Experiences. Berkeley: University of California Press.

Goffman, Erving. 1972. Interaction Ritual: Essays in Face-to-Face Behaviour. Harmondsworth: Penguin.

Grzybowski, Przemysław P. 2016. "Od tożsamości osobowej po zawodową: Etyczne dylematy badaczy zróżnicowania kulturowego" [From personal to professional identity: The ethical dilemmas of cultural diversity researchers]. In $Z$ teorii i praktyki badań międzykulturowych: Dylematy metodologiczne, edited by Tadeusz Lewowicki, Aniela Różańska, and Urszula Klajmon-Lech, 127-41. Cieszyn, Toruń: Wydawnictwo Adam Marszałek.

Halili, Rigels. 2012. Naród i jego pieśni: Rzecz o oralności, piśmienności i epice ludowej wśród Albańczyków i Serbów [The people and its songs: On orality, literacy, and folk narratives among Albanian and Serbs]. Warszawa: WUW.

Hammersley, Martyn, and Atkinson Paul. 2007. Ethnography: Principles in Practice. London: Routledge.

Kość-Ryżko, Katarzyna E. 2013. “Etnolog w labiryncie znaczeń kulturowych: Psychologiczne wyzwania badań terenowych" [The ethnologist in the maze of cultural meanings: The psychological challenges of fieldwork]. In Tematy trudne: Sytuacje badawcze, edited by Inga B. Kuźma, 15-46. Łódź: Wydawnictwo UŁ.

Koziej, Agata, et al. 2015. Kosowo: Społeczeństwo - kultura - polityka. Warszawa: Studium Europy Wschodniej.

Kudela-Świątek, Wiktoria. 2012. "Nieznośny ciężar przekładu, czyli o przekładzie źródeł mówionych w badaniach oral history" [The unbearable weight of translation, or on translation of oral sources in oral history research]. Wroctawski Rocznik Historii Mówionej 2: 5-35.

Kuźma, Inga B. 2013. "Tematy trudne - pola minowe - tabu w badaniu naukowym: Słowo wstępne" [Difficult topics - minefields - taboos in scientific research: Introduction]. In Tematy trudne: Sytuacje badawcze, edited by Inga B. Kuźma, 7-11. Łódź: Wydawnictwo UŁ.

Maciulewicz, Marzena 2015. "Badania terenowe na obszarze postkonfliktowym" [Fieldwork in a post-conflict area]. In Agata Koziej et al., Kosowo: Spoleczeństwo kultura - polityka, 13-24. Warszawa: Studium Europy Wschodniej UW.

Maciulewicz, Marzena, and Tomasz Rawski. 2011. "Próby terenowe" [Fieldwork trials]. In Maciej Falski, Małgorzata Maciulewicz, and Tomasz Rawski, Funkcje karnawału we współczesnym społeczeństwie chorwackim, 23-36. Warszawa: Instytut Slawistyki Zachodniej i Południowej UW. 
Marciniak, Łukasz T. 2010. “Konstruowanie tożsamości zawodowej: Procesy odniesienia i rozróżnienia" [Professional identity construction: Processes of identification and differentiation]. In Procesy tożsamościowe: Symboliczno-interakcyjny wymiar konstruowania ładu i nieładu społecznego, edited by Krzysztof T. Konecki and Anna Kacperczyk, 181-95. Łódź: Polskie Towarzystwo Socjologiczne.

Mencwel, Andrzej. 2006. Wyobraźnia antropologiczna [Anthropological imagination]. Warszawa: WUW.

Paczóska, Katarzyna. 2009. “Obserwujący obserwowani - o wizerunku antropologa w badanej społeczności" [The observants observed - on the image of the anthropologist in the studied community]. In Sasiedztwo w obliczu konfliktu: Relacje społeczne i etniczne $w$ zachodniej Macedonii - refleksje antropologiczne, edited by Karolina Bielenin-Lenczowska, 19-30. Warszawa: DiG.

Pink, Sarah. 2000. "Informants' Who Come 'Home."” In Constructing the Field: Ethnographic Fieldwork in the Contemporary World, edited by Vered Amit, 96-120. London: Routledge.

Rapior, Waldemar. 2015. "Intensyfikacja wyobraźni: O tożsamości osoby badacza i zawieszeniu bezwarunkowej obiektywności” [Intensifying imagination: On the personal identity of the researcher and the suspension of absolute objectivity]. Przegląd Socjologii Jakościowej 11 (1): 84-104.

Schmidt, Paweł. 2011. "Teren badań, wiedza i tożsamość badacza” [Fieldwork site, knowledge and researcher's identity]. In Teren $w$ antropologii: Praktyka badawcza we wspótczesnej antropologii kulturowej, edited by Tarzycjusz Buliński and Mariusz Kairski, 237-60. Poznań: Wydawnictwo Naukowe UAM

Stanisz, Agata. 2011. "Emocje i intymność w antropologicznym procesie badawczym: Problemy z tożsamościami” [Emotions and intimacy in anthropological research process: The problems with identities]. In Teren w antropologii: Praktyka badawcza we wspótczesnej antropologii kulturowej, edited by Tarzycjusz Buliński and Mariusz Kairski, 181-208. Poznań: Wydawnictwo Naukowe UAM

Wagner, Izabela. 2010. "Konstruowanie tożsamości międzynarodowego naukowca" [Constructing an international researcher's identity]. In Procesy tożsamościowe: Symboliczno-interakcyjny wymiar konstruowania ładu i nieładu społecznego, edited by Krzysztof T. Konecki and Anna Kacperczyk, 219-41. Łódź: Polskie Towarzystwo Socjologiczne.

Walczak, Bartłomiej. 2009. Antropolog jako Inny: Od pierwszych badań terenowych do wyzwań ponowoczesnej antropologii [The anthropologist as the Other: From the introduction of fieldwork to the challenges of postmodern anthropology]. Warszawa: Scholar.

\section{FINANCIAL SUPPORT}

The whole project:

V4; Erasmus; CEEPUS; Faculty of “Artes Liberales," University of Warsaw (shortterm stays). 


\section{Marzena Maciulewicz}

Workshops:

Faculty of “Artes Liberales" University of Warsaw; Foundation of the „Artes Liberales” Institute: Laboratory of Interdisciplinary Research "Artes Liberales"; Office of the Vice Rector for Research, University of Warsaw; Promotion Office of the University of Warsaw; UNMIK and private sources. 


\section{Kamil Maria Wielecki}

ORCID 0000-0003-0211-9884

University of Warsaw

INTERNATIONAL

AND INTERDISCIPLINARY DOCTORAL PROGRAMS IN THE POLISH ACADEMIC CULTURE -

OBSTACLES AND OPPORTUNITIES: OBSERVATIONS OF A GRADUATE AND COORDINATOR

\section{INTRODUCTION}

There is a growing interest in Poland, just like in other countries of Central and Eastern Europe, in the development of interdisciplinary education. On the one hand, this comes from a dissemination of the liberal arts educational models taken from the United States and Western Europe. On the other hand, the tendency results from efforts to create own models that would adjust state-financed higher education to challenges of the dynamically changing labor market (cf. Dahrendorf 2000; Kieniewicz 2007; Kontowski 2016; McGill Peterson 2012). Both the Polish Ministry of Education and Science and national 
agencies, such as the Foundation for Polish Science or the National Center for Research and Development, have assigned substantial resources to working out educational reforms and implementing particular programs. A number of publications have been written in order to find systemic solutions and analyze possibilities for applying interdisciplinary models at different levels of education and in various fields of the sciences (Axer and Wąsowicz 2015; Biliński 2015; O’Connor and Wilczek 2010).

One of the groups that played a crucial role in the dissemination of liberal education in Poland was the circle that gathered around Jerzy Axer. It was him who launched the Interdepartmental Individual Studies in the Humanities at the University of Warsaw in 1992 - a model that has since spread across many other Polish universities. It was also him who a year earlier founded at that University the Center for Studies on the Classical Tradition in Poland and East-Central Europe, which subsequently evolved into the Faculty of "Artes Liberales." Since the beginning, the milieu of "Artes Liberales" has focused their efforts on developing interdisciplinary approaches in both research projects and didactic programs at every level of higher education - undergraduate and graduate, both master's and doctoral, studies.

This article neither aspires to be an in-depth analysis of the functioning of doctoral studies in Poland nor does it propose any systemic solutions. ${ }^{1}$ However, it does have the advantage

${ }^{1}$ Such an analysis would require large scale research, as it would have to cover the dynamic changes the studies have undergone in the last few years. From the third level programs that had been offered by particular academic departments, enrolling a quite massive number of students, multiple doctoral programs were formed in 2018, which - due to the implementation of a new 
of being founded on direct knowledge that has been analyzed and implemented. The empirical basis for writing it encompasses my experience gained from three doctoral programs conducted at the Faculty of "Artes Liberales." The first was the International Doctoral Project "The Traditions of Mediterranean Humanism and the Challenges of Our Times: The Frontiers of Humanity" (otherwise known as MPD), ${ }^{2}$ which operated between 2010 and 2015. As a PhD student, I participated in it for the entire duration. The second was "Searching for Identity: Global Challenges, Local Traditions." This program ran between 2013 and 2017. There, I served as a scientific secretary of the program. The last one is the "Nature-Culture Program," which started in 2018 and will last until 2023, where I am the faculty member responsible for the coordination of the program. As it is an ongoing project and no final conclusions are available, I will make only occasional comments on the latter program. All in all, this paper proposes a personal, albeit possibly somewhat unsystematic, perspective of a participant, graduate, and coordinator.

The claim of this article reads as follows: while creating international and interdisciplinary doctoral programs, one should consider setting a special educational model as a guiding idea.

reform of higher education - were consolidated into so-called doctoral schools. At the University of Warsaw, there are currently four schools of this kind: the Humanities, Social Sciences, Exact and Natural Sciences, and Interdisciplinary Doctoral School. The creation of the latter one was inspired, among other things, by experiences of the "Artes Liberales." It is the only Interdisciplinary Doctoral School in entire Poland.

${ }^{2}$ MPD stands for "Międzynarodowy Projekt Doktorancki," the Polish equivalent for "International Doctoral Project." I use the Polish acronym as it was commonly accepted as the name of the program by its members. The acronym was also used in publications associated with the program. 
The model would be based on the functioning of program participants in a communication space that everyone contributes to and simultaneously draws from. ${ }^{3}$ Creating such a space requires a joint experience of building a community that involves all program members - both doctoral students and professors. Thus, the idea goes far beyond the individual responsibilities of each participant, including writing a doctoral dissertation. The communal and communicative dimensions of doctoral programs may bring some added value in the form of shaping teamwork skills and releasing human creativity.

I start with a brief description of two programs mentioned above - MPD and "Searching for Identity." In further sections, I present the pros and cons of interdisciplinary programs - on the one hand, the risks associated with organizing them, and on the other, the advantages that characterize them. Next, I proceed to the practical hints that can be used to make these programs run efficiently and effectively. Finally, I sum up my considerations, and refer to a potential dissemination of interdisciplinary doctoral programs as a model in the Polish academic culture.

\section{DOCTORAL PROGRAMS - OVERALL CHARACTERISTICS}

The goals and functioning of the MPD and "Searching for Identity" programs have been described elsewhere (Ackermann et al. 2015; International PhD Program n.d.; PhD Program

\footnotetext{
${ }^{3}$ I am inspired here by the theory of communicative action by Jürgen Habermas, especially by his concept of consensus-oriented communication (cf. Habermas 1984, 1987).
} 
Search for Identity n.d.). ${ }^{4}$ Here, it is enough to sketch their basic characteristics, similarities and differences.

MPD - headed by Jerzy Axer - was financed by a grant operated by the Foundation for Polish Science from resources gained from the European Regional Development Fund. Previously, there had been doctoral programs in Poland that used similar formulas, but the project launched by the Faculty of "Artes Liberales" in 2010 was the first of its kind in the field of the humanities and social sciences. PhD students of the program were selected in the process of careful recruitment (there were 13 candidates per place). Throughout four years, they received scholarships that allowed them to focus only on their research and writing. In addition, the program financed their internships abroad, conference trips, and the publication of their dissertations.

The "Searching for Identity" program - with Jan Kieniewicz in charge - was not founded on a grant basis. Unlike in the case of MPD, PhD candidates were admitted to the program from the pool of students who were already studying in the Faculty on the basis of their research topics, without any additional recruitment. Some external subsidies were gained by the program; while small, they enabled the organization of individual events, such as summer workshops. Doctoral students did not receive any scholarships except the ones they had managed to obtain themselves elsewhere (Erasmus Mundus, Ministry of Science and Higher Education). Half of

\footnotetext{
${ }^{4}$ For more information on the "Nature-Culture Program," see: PhD Program Nature-Culture n.d.
} 
them did not receive any money and had to work in order to sustain themselves.

Nonetheless, both programs were similar in terms of teaching and research methods, as well as the international composition of their participants. In MPD, even though all the professors came from Poland, several doctoral students came from other countries: Germany, Serbia, Hungary, and Ukraine. Officially, the program was conducted in English and this was the language of most of the dissertations. However, some dissertations were also written in Spanish, Italian, and in Polish. ${ }^{5}$ In "Searching for Identity," in turn, the Poles were not the dominant group, as they were in the case of MPD. Almost half of the doctoral students and professors came from Russia. To be precise, they represented not ethnic Russians but indigenous peoples of Siberia (the Buryats and the Yakuts). Also, one doctoral student from Ukraine participated in the program. In addition to English, Russian served as another official language during the program.

Both programs worked mainly within the fields of the humanities and social sciences. Their participants represented a wide spectrum of disciplines: cultural anthropology, history, and history of art, various philologies, linguistics, literary studies, pedagogy, and others. In this respect, the currently operating "Nature-Culture Program" is even more challenging. In both its goals and the composition of its members, the program creates a bridge between the arts, the humanities, social sciences, and natural sciences.

\footnotetext{
${ }^{5}$ Somewhat paradoxically, the two dissertations in Polish were written by non-Polish students. Thus, each of the doctoral students wrote his/her dissertation in a foreign language.
} 


\section{RISKS}

Conducting international and interdisciplinary doctoral studies carries many risks that may threaten the success of programs. Here I list the basic ones:

\section{Rejection of the idea of interdisciplinarity}

The basic risk of such programs is that doctoral students will cling to their research subjects and narrowly chosen academic disciplines. A few of the students from the described programs considered any suggestions and requirements that went beyond their standard way of operating to be unnecessary obstacles. As a result, interdisciplinarity remained a facade in their dissertations. This is not to say that a disciplinary research is necessarily of lesser quality than an interdisciplinary one. What I want to stress here is that if this kind of attitude prevails within interdisciplinary programs, their whole idea might break down - because it is undermined and rejected by the people to whom it is directed.

\section{Low level of cooperation between PhD students}

Other risks arise from diversity. $\mathrm{PhD}$ students come from different countries, represent various fields and areas of study, and work on different topics. They may simply not work well with one another, which may jeopardize some initiatives undertaken in the program. With a low level of integration, students are unwilling to contribute to the work of others, for example. One can illustrate this with the practice of peer-reviewing. Some 
doctoral students might be paralyzed by the thought of commenting on the work of others ("I don't know anything about it"). In addition, they simply might not want to do it ("I will I get nothing from it"). Moreover, they might focus on differences between themselves and the author rather than seek a common ground. In consequence, it might be difficult to get students to cooperate (even in the simple cases of preparing a common seminar, for instance) and in general make them reach for something more - something beyond their narrow research topics.

\section{Fragmentation of topics and deepening specialization}

The subjects of individual dissertations are usually very diverse in interdisciplinary programs. In addition, during the final year of the program, when the pressure to submit subsequent chapters of dissertations increases, students are less and less willing to engage in joint tasks. On the contrary, they tend to focus on their own doctorates. At the same time - due to the deepening specialization - it actually becomes increasingly difficult to honestly comment on the work of another person. In this way, the program members are subjected to further atomization. The danger is, therefore, that doctoral students will form a rather random mix of people and thus will not be able to build any research team.

This is a tendency that is difficult to counteract. Obviously enough, the main goal for a doctoral student is to accomplish his/ her thesis. Additionally, one cannot be proficient in everything. In practice, when challenged by requirements of peer-reviewing or teamwork, students tend to divide themselves into smaller 
circles of common interests, characters, background, etc. This while fully understandable - shows that some of the gaps separating participants might turn out to be too broad to be bridged.

\section{Getting lost in the maze of possibilities}

One of the reasons for rejecting interdisciplinarity may be a sense of confusion. A PhD student needs practical solutions that lead to their final success: writing a good doctoral dissertation. Meanwhile, in an interdisciplinary program, he/she meets a number of scholars - many of them being authorities in their fields - who propose their own ideas, interests, methodologies, etc. Thus, it is likely for students to commit mistakes in their research - by choosing dead ends, reflecting too much over details, and so on. On the one hand, this circumstance might constitute an additional incentive to follow just one disciplinary framework or a chosen authority. On the other hand, however, one learns from his/her mistakes and gains knowledge on what not to do, which proves to be very useful.

\section{ADVANTAGES}

\section{Cultural capital}

The international composition, variety of academic cultures, personal experiences, topics, and research methods, and finally internships abroad - all of that enriches the cultural capital of the program participants. Participation in such a diverse program stimulates your imagination - it broadens your horizon of what is possible. 
2. Increase in self-knowledge and quality of work

Participation in an interdisciplinary doctoral program makes you aware of the scale of your own ignorance. It poses an incentive to reduce this ignorance as much as possible. In the process of self-development, a doctoral student receives support from other program participants - both students and professors. His/her doctorate is of better quality because it has been evaluated by a number of people. In a doctoral program, students have several occasions to present results of their research to the public and receive valuable feedback. Therefore, they can improve their work through a dialectical movement.

3. Understanding the foundations of your discipline and learning to explain what you are doing

Frequent presentations of your work before people who have different educational backgrounds force you to thoroughly learn the foundations of your own discipline. At the same time, both your presentations and the foundations themselves are exposed to the pillory of criticism. Sometimes, questions that might seem simple may take you off-guard. In addition, even naive questions and comments signal to a doctoral student that his/her work may be incomprehensible to recipients. This is conducive to the development of a language and a presentation method that would be more communicative. MPD students were faced with tasks such as: "Tell me in two minutes who you are, what education you have received, and what you do," or "Specify the main question which your work answers." Such exercises are extremely useful because they train the ability to take your 
own research outside the academic world. They prepare, for instance, for meetings with the mass media when you have to be succint and able to say what you actually do and why.

\section{Teamwork skills}

Studying in an international and interdisciplinary program poses a real challenge for $\mathrm{PhD}$ students. It compels them to go beyond existing boundaries, broadening their knowledge and changing their thinking habits. Speaking about his impression after he had found himself in MPD, a former student recalled, "Jesus, the way I had thought before was so boring!" This also means that a graduate of interdisciplinary program will adapt faster to new conditions. It will likewise be easier for them to find a language of collaboration with people who are different. Such skills as the ability to quickly adapt, concisely present your research, or evaluate the work of others are necessary equipment not only on the path of scientific career but also in many other branches of the labor market.

\section{PRACTICAL SOLUTIONS}

\section{Funding}

Providing $\mathrm{PhD}$ students with resources that allow them to focus only on their research is a key element in the success of an international and interdisciplinary doctoral program. One cannot expect full commitment from people for whom studies are merely an after-hours activity. It is also difficult, then, to take punitive measures in case of their unsatisfactory performance. 


\section{Kamil Maria Wielecki}

Indeed, some professional activity usually has a positive influence on a scholar's work - it links you to the non-academic world and enriches your research with "real-life" experience. Interdisciplinary doctoral programs, however, are - or should be - an undertaking too demanding to practice on a part-time basis. This means that scholarships for doctoral students must be obtained within the existing structures (e.g., Ministry of Education and Science, Polish National Agency for Academic Exchange) or by winning a grant for opening a doctoral program.

\section{Management}

To organize the cooperation of sometimes a few dozen $\mathrm{PhD}$ students and professors (depending on the size of the program) over a period of four or five years is a sophisticated task, which therefore requires efficient management. A few administrative positions have to be created, including, first and foremost, a program coordinator. The coordinator should be a personality that is characterized by diligence, meticulousness, authority resulting from extensive knowledge, and effectiveness in enforcing rules. Of course, administrative duties constitute an additional financial burden for organizers of a program.

\section{Idea and co-creation of doctoral programs}

From the very beginning, basic principles of a program have to be clearly stated - i.e., why it is organized in an interdisciplinary way and what its participants can achieve together. In other words, one needs a guiding idea, a purpose which the founders of the program define before they open the recruitment doors. 
As students move on to the next stages of the program, this guiding idea can - or even should - be negotiated and adapted to changing needs. It is important, however, that this happens in a democratic way - that all program participants can influence its shape on an ongoing basis, make their suggestions, change the form of individual stages, etc. Co-creation of the program is the foundation for shared responsibility.

\section{Integration of participants}

A student who enters an interdisciplinary course of study usually does not know at what institution he/she has actually arrived and what the other program participants do - both professors and doctoral students. A good practice, then, is to organize semi-formal activities outside of academia, especially at the beginning of the program. Interpersonal ties often precede the establishment of scholarly ones. Quick orientation - who is who and who does what - significantly accelerates the beginning of a substantive cooperation. During further stages of the program, the integration of participants will benefit a faster and better performance of group tasks.

\section{Pedagogical training and other activities}

The activities that worked well in MPD included academic advising for students, peer-reviewing and academic duties, grant application workshops, and pedagogical training. In the "Searching for Identity" program, in turn, the tradition of summer workshops proved to be very worthwhile. The workshops (open to guests from outside the program) were three-day 
events with intense activities: conference lectures, student presentations, practical exercises, etc.

I will focus on pedagogical training here. Within MPD, two- or three-person teams of $\mathrm{PhD}$ students taught an undergraduate class at the Faculty of "Artes Liberales." Since the students came from different academic backgrounds and had different doctoral projects, their classes had an interdisciplinary dimension. A good rule of thumb was that the students were supported by a team of professors who shared in their experience and observed their work. Thanks to the consultations and their own teaching experience, $\mathrm{PhD}$ students were able to try various teaching methods and formulate their own teaching 280 philosophies. The pedagogical training gave me personally the very first opportunity to teach and - according to the rule of docendo discimus - I benefited greatly from it.

\section{CONCLUSIONS}

In the article, I have sketched the characteristics of two international and interdisciplinary doctoral programs that were organized at the Faculty of "Artes Liberales" at the University of Warsaw. Next, drawing on my own experiences from these programs and at the same time trying to generalize, I listed the disadvantages and advantages of such programs. In the following section, I named several practical solutions that can be used by their organizers. Now, I am going to summarize my observations and comment on the place of such projects in the Polish academic culture. 


\section{Interdisciplinary doctoral programs - for whom?}

Answering the question for whom?, I should state that interdisciplinary doctoral studies are not good for everyone and therefore they cannot serve as a mass educational model for the Polish academic culture. In my opinion, they should rather be addressed to students looking for "something more" - ones that are especially ambitious, hard-working, and self-disciplined. It is strong personalities who know what they want - both in professional and existential terms - that are fit for interdisciplinary studies. At the same time, strong does not mean arrogant: the students have to be open to criticism and new ideas. In addition, those who already have experience in crossing discipline boundaries will find themselves well suited for such studies - those who graduated from interdisciplinary MA curricula or have diplomas in various fields. These programs are best suited for people who will make the best use of the opportunities offered in interdisciplinary programs and will not get lost in the maze of proposed paths. For such people, a special freedom afforded by the programs will not pose a burden but on the contrary - a leverage factor.

\section{Interdisciplinary doctoral programs - what for?}

In the claim I put forward in the introduction, I proposed setting the creation of a specific communication space as the guiding idea of international interdisciplinary programs. I would add here that cooperation in that space has to be based on trust and propriety that are necessary conditions of substantive discussion, constructive criticism, and the possibility of learning 
from one's own mistakes. At this point, however, one can ask: what is the use of a space like this?

My answer is that in such a space, soft skills are shaped that are nowadays heavily demanded - teamwork, imagination, quick adaptation to dynamic circumstances, creative thinking, and innovative action. This is true because the need for a deep understanding with other program participants poses a challenge. The participants come from different countries, are of different ages, have different experiences, etc. In addition, they are rooted in various disciplines and academic cultures. Overcoming such obstacles equips you with practical knowledge that you can implement in many other situations.

Having said that, I should note that connecting humanists and social science scholars is still relatively simple: a far more difficult project entails building research teams composed, in addition, of representatives of other branches of science. The latter is being attempted in the ongoing "Nature-Culture Program" at the Faculty of "Artes Liberales."

\section{Interdisciplinarity in practice}

What today's scholars often suffer from is isolation and fragmentation of their work. Researchers specialize in their fields to such extent that it is difficult for them to extrapolate beyond their narrow niches: they lack external feedback and at the same time they are incapable to comment on the work of others. The interdisciplinarity and teamwork formula allows them to get out of this compartment and link their research to issues that are more universal. Even if a graduate does not continue on an 
academic path after receiving a $\mathrm{PhD}$, skills developed during interdisciplinary studies will certainly prove useful for him/her either way. The labor market and economic reality are changing so rapidly that it is difficult to predict which occupations will be sought after in a few years' time. What is certain, however, is that skills such as critical thinking, creativity, and openness to change will not be outdated. Quite the opposite: graduates of these programs will have a chance to fill various market niches thanks to their ability to adapt and find an agreement across divisions. Last but not least, international programs force their participants to master foreign language skills - and those skills are of crucial importance in the labor market today.

Interdisciplinary studies will remain a niche in the Polish academic culture, where the education system is founded on a hierarchical disciplinary structure. At the end of the day, even a graduate of interdisciplinary studies receives a diploma in a discipline. And the diploma, or the studies themselves, become a cause for the appearance of "tribal identities." Mutual relations of those "tribes" are a domain full of stereotypes and superstitions: here the sociologists place themselves above anthropologists who, in turn, despise cultural studies scholars. Whether we want it or not, we live among disciplines and even worse: we still need them. Nevertheless, the structure of the university system is changing and the field of interdisciplinarity is expanding. International and interdisciplinary doctoral programs, therefore, may become a catalyst for alternative education. 


\section{REFERENCES}

Ackermann, Ines K. et al. 2015. Imagine There Where No Humanities. Warszawa: Wydawnictwo DiG.

Axer, Jerzy, and Marek Wąsowicz. 2015. Reguła czy wyjątek? Interdyscyplinarność $w$ polskich uniwersytetach [Rule or exception? Interdisciplinarity in Polish universities]. Warszawa: Uniwersytet Warszawski; Ministerstwo Nauki i Szkolnictwa Wyższego.

Biliński, Szczepan, ed. 2015. Szkolnictwo wyższe w obliczu zmian [Higher education faces change]. Kraków: Polska Akademia Umiejętności.

Dahrendorf, Ralf. 2000. Universities after Communism. Hamburg: Edition KörberStiftung.

Habermas, Jürgen. 1984. Reason and the Rationalization of Society. Vol. 1 of The Theory of Communicative Action. Translated by Thomas McCarthy. Boston: Beacon Press.

Habermas, Jürgen. 1987. Lifeworld and System: A Critique of Functionalist Reason. Vol. 2 of The Theory of Communicative Action. Translated by Thomas McCarthy. Boston: Beacon Press.

"International PhD Program The Traditions of Mediterranean Humanism and the Challenges of Our Times: The Frontiers of Humanity." n.d. Accessed October 25, 2019. http://mpd.ibi.uw.edu.pl/

Kieniewicz, Jan, ed. 2007. Autonomia uniwersytetu: Jej przyjaciele $i$ wrogowie [The autonomous university: Its friends and foes]. Warszawa: Fundacja "Instytut Artes Liberales”; Bobowa: Pszczelarska Oficyna Wydawnicza Maciej Rysiewicz.

Kontowski, Daniel. 2016. "On the Verge of Liberal Arts Education: The Case of MISH in Poland." Working Papers in Higher Education Studies 2 (1): 58-94.

McGill Peterson, Patti. 2012. Confronting Challenges to the Liberal Arts Curriculum: Perspectives of Developing and Transitional Countries. London: Routledge.

O'Connor, Mark, and Piotr Wilczek, eds. 2010. Collegium - college - kolegium: Kolegium $i$ wspólnota akademicka $w$ tradycji europejskiej $i$ amerykańskiej [Collegium - college - kolegium: The collegium and the academic community in European and American traditions]. Boston, Warszawa: Wydawnictwo Naukowe Sub Lupa.

"PhD Program Nature-Culture." n.d. Accessed October 25, 2019. https://nature-culture. al.uw.edu.pl/

"PhD Program Searching for Identity: Global Challenges, Local Traditions." n.d. Accessed October 25, 2019. http://www.isd.al.uw.edu.pl/searching.php 


\section{INTERCULTURAL COMMUNICATION AS A COMPONENT OF ACADEMIC CHANGE}




\section{Valeria Korablyova \\ ORCID 0000-0003-4523-7557 \\ Charles University, Prague}

\section{IMAGINING A MODERN POLAND: LESSONS FOR UKRAINE*}

We have seen that a free Poland can exist without a free Ukraine. ... as well as that there can be a democratic Ukraine without a democratic Poland. ${ }^{1}$

Katarzyna Petczyńska-Nałęcz

\section{INTRODUCTION:}

\section{AWAY FROM THE GIEDROYC DOCTRINE}

I am opening this paper with a quote from former Ambassador of Poland to Russia Katarzyna Pełczyńska-Nałęcz, a quote which is illuminating in several ways. First and foremost, it highlights an important recent shift in Polish-Ukrainian relations marking a desynchronization in the development of these two countries, but also it hints on the new intrusive factor that enabled this shift, namely the EU and NATO umbrella that arguably decreased the importance of Ukraine for Poland's national security and independence. Indeed, the so-called Giedroyc

\footnotetext{
* The research behind this article was conducted on a grant from the Artes Liberales Institute Foundation and Open Society Foundation's Global Dialogues Project in 2016-2017.

${ }^{1}$ A quote from the debate in the Batory Foundation, held in Warsaw on November 22, 2016, titled "Ukraine fatigue?"
} 
doctrine used to be the backbone of Poland's Eastern foreign policy for the most part of its post-communist history (and its underlying ideas can be traced back to the interwar period). Its core imperative prescribes that Poland should prop up the aspirations for sovereignty of its neighboring countries, Ukraine, Lithuania, and Belarus, which supposedly reinforces Poland's own sovereignty against Russia's (neo-)imperial claims. And to that end, Poland has to give up on its own quasi-imperial pretensions towards these very countries. Thus, the destiny of all the countries in question gets bound in the face of the common enemy standing as a threat to their autonomy, and the danger is so vital that it is capable of mitigating the complexities and sensitive issues of shared history. What is crucial in this context is that the doctrine's argument is seemingly rational and geopolitical (rather than moral and historical): collaboration and strategic partnership is beneficial to all the parties in the first place. Zbigniew Brzezinski in his sound work The Grand Chessboard formulated it in the following way:

the very existence of an independent Ukrainian nation encourages the transformation of Russia. ... Ukraine's loss of independence would have immediate consequences for Central and Eastern Europe, turning Poland into a geopolitical linchpin on the eastern border of a united Europe (Brzezinski 1998, 56).

Such an approach resulted in Poland adopting the role of "Ukraine's advocate" in Europe and before the US, while Ukraine found itself a sort of a frontier of Europe or - at best - a bridge connecting Europe and Russia. Indeed, back in 1991, Poland was the first state that recognized Ukraine's 
Independence Act, passed in the Ukrainian parliament on August 24, 1991, and confirmed in the nationwide referendum on December 1, 1991 (Uchwała 1991). Later on, this continued in several significant accomplishments concerning bilateral agreements, Ukraine's accession to international organizations, and active mediation by the Polish authorities in Ukraine's internal political crises (Kapuśniak 2009). However, after Poland became a NATO member in 1999 and an EU member-state in 2004, it started drifting away from the Giedroyc doctrine and adapting common European policies towards Ukraine and, crucially, towards Russia. Donald Tusk's visit to Moscow in January 2008, soon after the Civic Platform (PO) won the parliamentary election and formed the government, was a symptom of this move to "normalize relations" with Russia. ${ }^{2}$ In early 2017, the Ukrainian online resource Zbruc published a translation of the document from the Polish archives dating back to March 2008, which was a draft for a new Eastern policy strategy prepared by Jarosław Bratkiewicz (Bratkievich 2017), the then Vice-Head of the Department for Strategic Planning of Foreign Policies and Head of Eastern Department of the Ministry of Foreign Affairs (in the team of Minister of Foreign Affairs Radosław Sikorski). The document criticizes the dominant canon of "patriotic correctness," portraying Russia as an eternal enemy and Ukraine as a strategic partner. What was suggested instead was the following:

${ }^{2}$ A visit to Kyiv came after the visit to Moscow, which was largely perceived as a reflection of a new hierarchy of the Polish government's priorities in foreign policy. 
Even disregarding the colossal economic interests of Poland in Russia which are not confined to energy issues, though these certainly play a significant role in the Polish-Russian and Russian-EU relations - as well as the mutual cultural and intellectual interests, it is worth stressing that animated dialogue with Russia stands as a separate political value in itself for Poland. Not only because it makes unsubstantiated any accusations of "Polish Russophobia" but also because it strengthens the role of Poland in the Western family as the main expert on Russia. Considering the inevitable interest of the West in Russia - incommensurable with interest in any other post-Soviet country, including Ukraine - the Polish know how in the Russian affairs in an era of information meritocracy represents a key value in building our image and position in the Western world (Bratkievich 2017). ${ }^{3}$

Given that the cited document corresponds with some actions undertaken by the Polish authorities, it arguably represents a clear shift away from the Giedroyc doctrine, this time towards Realpolitik, or pragmatic reasoning in Poland's foreign affairs aimed at working out and maintaining relations with the main geopolitical actors. Leaving aside conspiracy theories, I would rather argue that the document elaborates on the first part of the epigraph to this paper: Poland's accession to the EU and NATO provided the state with guaranties of economic and military security, which in turn made the Intermarium concept redundant and outdated. The flip side of such an approach, however, is that Poland is protected as long as the afore-mentioned institutions are operative. Yet when NATO gets impotent and the EU is fragile (which does not seem inconceivable nowadays), the strategic partnership with neighboring countries is back on the table. ${ }^{4}$

\footnotetext{
${ }^{3}$ From here onwards, the italics are mine.

${ }^{4}$ More on that can be found in: Umland 2017.
} 
Another shift away from the Giedroyc doctrine has recently become tangible. After 2015, when the Law and Justice party (PiS) gained a majority in the parliamentary election, turning from a fringe conservative party to the political mainstream, a U-turn in Poland's domestic and foreign policies has been made. This shift can be framed as one from Realpolitik to the politics of fear (Gaston and Harrison-Evans 2017), where the latter presupposes the perception of neighboring countries as foes involved in plots against Poland. The "Smolensk cult" got subsequently complemented with the "Volhynia cult," which was accompanied by a growing frustration with the EU. According to the results of a sociological survey on the attitudes to other nations (Omyła-Rudzka 2016), from 2015 to 2016 the attitude of the Poles to sixteen nations - out of twenty-seven included in the survey - significantly deteriorated. A noteworthy decrease in the attitudes to the neighboring nations, namely to the Ukrainians (an index of $-0,29$ on the scale from -3 to +3$)$, the Belarusians $(-0,18)$, the Lithuanians $(-0,22)$, and the Germans $(-0,26)$, has to be mentioned separately (albeit the level of hatred towards them did not reach the early 1990s level) (Omyła-Rudzka 2016, 3-7).

The Polish-Ukrainian relations have never followed a linear trajectory but rather fluctuated depending on the historical circumstances. That the recent developments took a turn away from the Giedroyc doctrine by no means implies an absence of anti-Ukrainian sentiments beforehand or pro-Ukrainian actions afterwards. Instead, it illuminates several tipping points, potentially restructuring the framework of bilateral relations 
and triggering mutual re-adjustments of national imaginaries. The rationale of this paper is to trace the post-communist reemergence of Poland as a modern nation-state, with a special focus on the national imaginaries produced thereof, and the repercussions in the images of "significant Others" this entailed, and to offer a conclusion about what important lessons for Ukraine should be drawn from that. Therefore, the paper is not focused specifically on the Polish-Ukrainian relations. Instead, it starts from the following assumptions. Throughout the 19 th to 21 st centuries, both countries have been facing similar challenges of (re-)imagining themselves as sovereign (and, arguably, modern) nation-states and of re-assessing their 292 relations with neighboring countries. They were both initially dependent on the Romantic model of nation-building, both have suffered momentous historical traumas, and, moreover, they share common "significant Others," namely Europe / the West, on the one hand (as well as, more specifically, Germany, especially in the Polish case), and Russia, on the other. I would argue that mutual construction of each other's images has been largely instrumental for both Poles and Ukrainians in positioning themselves on this dominant axis - between Russia and the West. There are points of convergence and divergence between the two nations, but all in all, the examination of the Polish developments embodies important historical lessons for Ukraine. To quote the catchy subtitle of Timothy Snyder's book (Snyder 2016), it represents the history as a lesson and a warning - rather than simply a template to emulate (as Poles often tend to think, somewhat complacently). I will focus on the 
nation-building process in Poland, examined through the threefold framework of "revolution - transition - reaction," where 1980, 1989, and 2015 stand as the main reference points. I would argue that the dominant national imaginary has repeatedly failed to "break through into modernity." These failures prompted a false dichotomy between genuine "Polishness" rooted in ethnicity and traditions and "Europeanization" as colonization, or national betrayal. Nevertheless, active social groups and parts of public discourses that emerged throughout this modernization produced a vibrant civil society, capable of promoting a modern Polish national imaginary. I will conclude with a suggestion as to how contemporary Ukraine can build up on the Polish experience.

\section{THE POLISH NATIONAL IMAGINARY:}

FAILED MODERNIZATION

\section{AND THE RECURRENT ROMANTIC MODEL}

Andrzej Leder, in his resonant book $A$ Waking-Dream Revolution (Leder 2014), claims that in 1939-1956, Poland underwent a social revolution that radically transformed the fabric of the Polish society, yet was largely misrecognized as such. Leder argues that it incited probably the most significant change in the Polish mentality, marked with the emergence of the urban way of life and of the middle class - as opposed to the rurally defined "Polishness." However, a failure to recognize this shift enforced the traditional Romantic mentality, what Leder calls the gentry imaginary, centered around a Romantic 
universum. Indeed, this crucial period of the Polish history entailed two important consequences for Poland's further development. First, it made the Polish society more ethnically and religiously homogenous, due to the ethnic cleansing, migration, and assimilatory policies. But also it provided with strong evidence the Polish martyrdom concept: developing on Adam Mickiewicz's metaphor of the "Christ of nations," it also legitimized the policies of affirmative action towards the Poles. The underlying assumption that having suffered that much, the Polish nation is immune from any accusations of oppressing other ethnic groups, comes to the fore in discussions of the Holocaust in the Polish lands, particularly around the book by Jan T. Gross (2002).

Revolution is widely recognized as the main means of historical advancement in Europe. Thus, the well-known post-colonial theorist Dipesh Chakrabarty mentions three key absences in the history of India that supposedly support the claims of its historical backwardness: no bourgeois revolution, no proletarian revolution, and no peasant revolution in the anamnesis (Chakrabarty 2000). Along these lines, the American historian Martin Malia claims: "what we call revolutions are a historically specific phenomenon - in fact, specific to Europe and, during the last century, the area of European influence" (Malia 2006, 1). And he does not stop there. His main idea is that every nation in Europe (or one belonging to the European cultural area) has one historical chance to break through into modernity and thus to put itself on par with the great European nations: 
The drama of a Great Revolution can occur only once in a given nation's history, not for any metaphysical reasons of historical necessity, but for the thoroughly mundane reason that any given nation has only one Old Regime to be liquidated, and that once this has been accomplished - or even attempted - a millennial historical divide has been irretrievably crossed (Malia 2006, 279).

Thus, a revolution is the founding event in establishing a modern nation. It must be distinguished from a revolt, or a class uprising, as it unites most of the society against the Ancien Régime. Malia specifies it as a struggle against monarchy, aristocracy, and clergy, which is aimed at the human emancipation and the creation of a "new man." Leder accepts this reasoning and mentions that revolution is not only about changing a political system or groups in power (then it is simply a coup), but is a fundamental transformation of the social substance, a change in economic and cultural hierarchies (Leder 2014, 30). He adds that a revolution is accomplished under the following condition:

There must emerge a new metaphysics, a new system of beliefs, and sometimes an ideology connected with it, for revolutionary changes to get traction. First, what is crucial for making a revolution possible is the emergence of a new imaginary, even in the form of a utopian sketch, of a project, an object of desire. The next step is for a new master signifier to penetrate the social consciousness, to become self-evident for most of the people (Leder 2014, 28-29).

Therefore, one should focus on the transformations of mentality and mindsets rather than on groups in power. And this argument leads me to the hypothesis that 1980 instigated a modern revolution in the history of Poland, which is, as of now, unfulfilled, yet has not failed, as some scholars hastily 
claimed (Krasnodębski 2005; Ost 2005). Going back to Malia's approach, a modern revolution (or, in his words, a Great Revolution) is not a singular event but a continuous struggle. In the case of Germany, for instance, it took almost a century, from 1848 to 1945 , for it to re-establish itself as a modern nation. And it seems that in Poland the struggle is still on.

\section{0, 1989, AND BEYOND}

What is missing in Malia's approach is that a breakthrough into modernity happens not only in metropoles but in colonies as well, and there the task is twofold - to secede from the 296 colonial dominance and to overturn the old regime at home, which makes sense only if the colonizer itself does not belong to the European core; otherwise colonization implies forced modernization, and the attitude to modernity becomes ambiguous. Poland and Ukraine stand as strong cases of the former situation, when an anti-colonial struggle is wrapped in pro-European rhetoric, yet it must be conducted on one's own, in order not to slip into subordination to another metropole. What I mean here is that a genuine revolution presupposes gaining voice, acquiring political agency, and also inventing new modes of struggle - not a repetition of old patterns, nor beating enemies with the hands of others. In all these senses, the Solidarity movement instigated a modern revolution in Poland (and so did the Maidan in Ukraine). 
The revolutionary moment within the Solidarity movement was about people turning into citizens by acquiring a voice and political agency. It was a general strike, in Walter Benjamin's formulation, as it managed to involve the majority of the Polish society. It started with a workers' strike, yet its demands, shifting from mere economic to political ones, spoke to the rest of the country. Testimonies from the participants show the excitement of gaining voice. As Professor Ireneusz Krzemiński describes it, ${ }^{5}$ repeated gatherings were being held throughout 1980-1981, where different attendees, regardless of their formal status, could take the floor and express their opinion on different issues, and they felt it to be a refreshing experience. This symbolic inclusion was essentially egalitarian, and it moved beyond the traditional hierarchy of the Polish society. Moreover, as noted by Jan Lityński, ${ }^{6}$ the editor of the KOR periodical Robotnik, before Solidarity, the main symbolic figure had been "Them" ("Oni"), the officials of the PRL, but within the movement an "Us" emerged. I believe this signified a shift in the polity from an identity that was negative or transpassive (as Leder terms it) to a positive, active one, as it became centered not around an adversary figure as the main identifier, but was driven by a desire to identify who "We" were, what the Polish polity was about, and what goals it strove to achieve.

Another major shift concerned the restructuring of the public discourse from a binary to a ternary one. Paweł Rojek, in his

\footnotetext{
${ }^{5}$ During Prof. Krzemiński’s course "Dlaczego warto pamiętać o Solidarności?” ("Why should we remember about Solidarity?"), taught at the Faculty of "Artes Liberales," University of Warsaw, in the academic year 2016-2017.

${ }^{6}$ At his presentation as a guest speaker within Prof. Krzemiński’s course.
} 
book The Semiotics of Solidarity (Rojek 2009), uses the semiotic theory of Soviet scholars from Tartu, Yuri Lotman and Boris Uspensky, to argue that the Solidarity movement produced a new type of public discourse in Poland, one which was open to alternative opinions and incorporated them by constantly revising its own assumptions. Following Lotman and Uspensky, he argues that the Polish official discourse was binary, and so has been the Russian discourse throughout centuries, whereas the Western European discourse is inherently ternary, and realistic (as opposed to Romantic). This framework seems fruitful for the analysis of the recent events, as it puts the very structure of the discourse in focus, disregarding its content, and it persuasively shows that binarization of the discourse results in the antagonization of society. A side argument, also highly relevant in this context, is about drawing a clear distinction between the event that was Solidarity and post-1989 developments, the latter being discursively binary, according to the author. This claim can be paralleled with Adam Michnik's remark:

For us, the people of the democratic opposition, rebellion against communism was a rejection of official lies and [a rebellion] against that culture of monolog. In a spirit of dialog and pluralism, we rejected the idea of overthrowing the dictatorship. Today, it is clear that communism created as its antithesis not only an attitude of dialog and pluralism, but also a philosophy of replacing the communist monolog with an anticommunist monolog. ... [T] he democratic [opposition] confronted the monolog of the communists' version of history with a polyphonic voice. The official canon, variously experienced and described, was challenged by various historical truths (Michnik 2009, 447, 451).

Was the post-1989 transition a success or a failure? The recent research made by the team of the Institute of Public Affairs in 
Warsaw highlights two competing narratives in this regard: one of Poland as a "green island," a poster child of the Eastern Enlargement, and another one of "Poland in ruins," a loser in the democratic transition. The former relies on economic data, depicting Poland as "one of the best-performing European countries in Europe since the collapse of the Iron Curtain":

Since 1989, there has not been a single year of economic contraction in Poland, not even during the 2008 economic crisis or subsequent Eurozone crisis. ... Taking into account the whole period since accession to the EU (2004-2015), Poland performed relatively well despite the crisis: nominal average yearly earnings nearly doubled, minimum wage increased more than twice, unemployment decreased by 11.6 percentage points, relative poverty dropped by 3.3 percentage points and extreme poverty dropped by 5.3 percentage points (Gaston and Harrison-Evans 2017, 316, 319).

On the other hand, during the presidential election in 2015 , the Law and Justice party successfully promoted another vision, codified as Poland in ruins, "depicting Poland as a country where few benefited from growth and the masses were increasingly impoverished" (Gaston and Harrison-Evans 2017, 310). The authors conclude that "socioeconomic factors, especially income inequality, do not fully explain the electoral success of authoritarian populism in Poland," what is crucial instead is "amplifying fears" (Gaston and Harrison-Evans 2017, 305) and creating a dreadful picture having little to do with reality. However, such a juxtaposition seems to be a simplification. I would argue that the post-1989 transition is largely perceived as a failure both because it failed and because it succeeded.

Back in 1991, the GDPs per capita in Poland and Ukraine were roughly the same; in 2015, there is a significant gap 
between the indexes in the two countries, with the Polish index being 6 times higher ( $\$ 12,414$ vs. $\$ 2,186$ per capita) (World Bank Data 2017). Middle-aged Ukrainians still remember mobs of Poles that came to the country in the mid-1990s to buy food and electronics while flooding the market with cheap clothes. These days, hundreds of thousands Ukrainians are moving to Poland looking for a job, often living in extremely precarious conditions, while many young people prefer Polish universities to Ukrainian ones. That explains why, from the Ukrainian perspective, the Polish case stands as a success story, but this has little to do with the Poles' own perception.

Having joined the EU, the Poles changed the system of 300 coordinates: from that moment on, they started comparing themselves to the EU member states rather than to former Soviet countries. Entering the Schengen Area not only opened state borders for the Polish citizens, but also opened their mental horizons and set new standards for them. Going back to figures, $\$ 12,414$ per capita in Poland is 3,5 times less than the GDP in Germany and the UK $(\$ 41,324$ and $\$ 40,367$ in 2016 , respectively) (World Bank Data 2017). The economic situation improved significantly, yet it remained hardly comparable with the Western countries: "In 2014, average earnings in Poland were more than three times smaller than average earnings in the EU and just over a fifth of the average wage in the UK - the preferred destination for Polish migrants" (Gaston and Harrison-Evans 2017, 319).

Moreover, the transition entailed a post-industrial transformation of economy that marginalized industrial production and 
introduced precarious jobs, especially for young people. Mass migration, increasing precarity of life, coupled with growing expectations, barely corresponded with the emotional underpinning of the Polish success story promoted within the Civic Platform campaign in 2015. On the other hand, political and economic freedoms started being taken for granted, whereas the Soviet experience ceased to be a reference point. Thus, some of the frustration that the transition brought was precisely because it succeeded. By virtue of Poland turning into a European country, the Poles started evaluating their own life by the European standards.

There is also a post-colonial moment to be stressed here. As was mentioned above, the revolution was about people gaining voice - not only in governing their country but presumably their own voice in the European family. As Václav Havel stated in his speech in the Polish Sejm back in 1990:

We have the chance to transfer Central Europe from a phenomenon that has so far been historical and spiritual into a political phenomenon ... to transform them [Central European states] into a definite special body, which would approach Western Europe not as a poor dissident or a helpless, searching amnestied prisoner, but as someone who has something to offer (Havel 1990).

I believe those expectations largely failed to materialize, as Central European states found themselves in the position of democratic apprentices, forced to catch up and not expected to suggest anything genuine and universally worthy. This was perceived as humiliation and it produced the sentiments fueling PiS's propaganda. 
To conclude, the Solidarity movement comprised a revolutionary moment, yet this experience barely speaks to contemporary Poles. Youngsters do not comprehend what it was aimed against, as the Soviet threat means nothing to them. At the same time, Solidarity's pro-European aspirations are largely assessed through the post-1989 transformation. Thus, the movement was reduced to a historical moment that ousted the PRL authorities from power, and it got inscribed into the national mythology of struggles and martyrdom. Well-known Polish philosopher Marcin Król sadly remarked "We were foolish" ("Byliśmy głupi") (Król 2014), and it perfectly sums up the resentment of the Polish intellectual elites over the lost chance of remaking Poland in a brand new, modern way:

In a sense, Polish politics is still the same conversation from 30 years ago about who is the biggest hero, and about curing those complexes. ... Our impotence can also be seen in the absence of any utopian thinking, any ideology. No one designs the world anew (Król 2014).

The current anti-European moods have been largely fueled by the failure of the "West" to recognize the "East" as an equal partner in re-imagining the future of the continent by overcoming the flaws of the neoliberal project of the EU. Arguably, the Solidarity movement and the people inspired by it suggested such an opportunity of creating an alternative vision, but as of now, it remains unfulfilled. Instead, a counter-revolution searching for a Sonderweg for Poland has been unfolding in the country. I would argue that by the same token Poland has been emulating Russia's template: despite the persistent anti-Russian rhetoric in the official discourse, all the recent developments 
push the country towards the pool of Russia's allies. The rise of xenophobia, the alliance of the clergy and the authorities, attempts to monopolize the media and education - all this marks a shift towards a "subaltern empire" (Morozov 2015) seeking to mitigate old traumas and complexes. An interesting symptom in this context is the new media strategy. In 2017, the then Foreign Minister Witold Waszczykowski announced plans of drastically reducing funding of TV Belsat (a media outlet broadcasting in Belarus to counter the official discourse) and using the savings to fund a new Polish-language channel to be broadcast abroad (Pełczyńska-Nałęcz 2017). This shift from supporting non-government-run media in the ULB countries to promoting Polishness and Polish visions in the neighboring states interestingly rhymes with Russia Today's mission. In the midst of the Euromaidan in Ukraine, on December 9, 2013, the news agency RIA "Novosti” (established in June 1941, just two days after Nazi Germany attacked the Soviet Union) was transformed into the International Information Agency "Russia Today," listed among strategic state objects (Ukaz 2013). Dmitry Kiselyov, its Head, personally appointed by President Putin, declared: "The restoration of a just attitude to Russia as an important country with good intentions, that is the mission of the new institution I will lead" (Kiseliov 2013).

\section{CONCLUSION}

For several recent years, the world has been crossing a historical caesura whereby the future is giving way to l'avenir, 
that is to an unpredictable future. What Ivan Krastev calls a conservative counter-revolution (Krastev 2016) must be perceived as an attack on the European modernity. Against this background, the recent history of "New Europe" striving to build modern nation-states is worth a closer examination. Arguably, peripheral European nations have moved to the forefront of the current poly-crisis, potentially suggesting valuable lessons to the "developed" world (Gessen 2016; Sierakowski 2017). Keeping that in mind, I would argue that re-imagining Poland and Ukraine as modern nation-states is not simply a matter of retarded modernization, or catching-up with the symbolic "West." Nowadays, the very future of united Europe - or even 304 more broadly, of the project of modernity - is at stake: its success on the eastern fringe of Europe can reinvigorate the whole project, while its failure will empower the alt-right International.

Ukraine has its peculiarity in comparison to Poland. Its heterogeneity, oftentimes perceived as its weak point, is indeed a safety catch preventing a backslide to archaic, pre-modern models. To put it differently, unlike Poland, Ukraine cannot choose between the past-oriented and future-oriented advancement, or between retrotopia and utopia. The country is too diverse in its culture and history to invent a shared vision of the past reconciling most of its population. Yet if reconciliation fails, the symbolic split will lead to the loss of the state's independency. What has the power to unite the country is a project of a shared future, and such impulse emerged on the Maidan square. As renown Ukrainian singer and civil activist Slavko Vakarchuk put it: "Do not consider Ukraine the land of 


\section{your fathers. Consider it the land of your children. And then changes will come..." (Vakarchuk 2014).}

\section{REFERENCES}

Bratkievich, Iaroslav [Jarosław Bratkiewicz]. 2017. "Tezy pro polityku RP shchodo Rosii i Ukrainy" [Theses on Poland's policies towards Russia and Ukraine]. Translated by O.D. First published 2008. Zbruc, January 24. Accessed December 23, 2017. http://zbruc.eu/node/61422

Brzezinski, Zbigniew. 1998. The Grand Chessboard: American Primacy and Its Geostrategic Imperatives. New York: Basic Books.

Chakrabarty, Dipesh. 2000. Provincializing Europe: Postcolonial Thought and Historical Difference. Princeton: Princeton University Press.

Gaston, Sophie, and Peter Harrison-Evans. 2017. Mapping and Responding to the Rising Culture and Politics of Fear in the European Union: Nothing to Fear but Fear Itself? Summary Report. London: Demos.

Gessen, Masha. 2016. "Autocracy: Rules for Survival." The New York Review of Books, November 10. Accessed December 23, 2017. http://www.nybooks.com/ daily/2016/11/10/trump-election-autocracy-rules-for-survival/

Gross, Jan T. 2002. Neighbors: The Destruction of the Jewish Community in Jedwabne, Poland. New York: Penguin Books.

Havel, Vaclav. 1990. "President Vaclav Havel's Speech to the Polish Sejm and Senate, January 21, 1990." East European Reporter 4: 55-57.

Kapuśniak, Tomasz. 2009. "Polityka Polski wobec Ukrainy" [The Polish policy toward Ukraine]. In Polityka wschodnia Polski: Uwarunkowania, koncepcje, realizacja, edited by Andrzej Gil and Tomasz Kapuśniak, 219-32. Lublin: Instytut Europy Środkowo-Wschodniej.

Kiseliov, Dmitry. 2013. "Kiseliov rasskazal o missii novogo gosudarstvennogo SMI" [Kiselyov speaks on the mission of the new state media outlet]. Lenta.ru, December 9, 2013. Accessed December 23, 2017. https://lenta.ru/news/2013/12/09/kisselyov/ Krasnodębski, Zdzisław. 2005. Demokracja peryferii [Democracy of the peripheries]. Gdańsk: Słowo/obraz terytoria.

Krastev, Ivan. 2016. "2017 könnte ein Revolutionsjahr wie 1917 werden” [2017 could be a year of revolution like 1917]. Interview by Christian Ultsch. Die Presse, November 19. Accessed December 23, 2017. http://diepresse.com/home/ausland/ aussenpolitik/5121092/2017-koennte-ein-Revolutionsjahr-wie-1917-werden

Król, Marcin. 2014. "Byliśmy głupi” [We were stupid]. Interview by Grzegorz Sroczyński. Gazeta Wyborcza, February 7. Accessed December 23, 2017. http://wyborcza.pl/ magazyn/1,124059,15414610,Bylismy_glupi.html?disableRedirects=true

Leder, Andrzej. 2014. Prześniona rewolucja: Ćwiczenie z logiki historycznej [A wakingdream revolution: An exercise in historical logic]. Warszawa: Wydawnictwo Krytyki Politycznej. 


\section{Valeria Korablyova}

Malia, Martin. 2006. History's Locomotives: Revolutions and the Making of the Modern World. New Haven: Yale University Press.

Michnik, Adam. 2009. "The Trouble with History: Tradition: Imprisonment or Liberation?" International Journal of Politics, Culture, and Society 22: 445-52.

Morozov, Viatcheslav. 2015. Russia's Postcolonial Identity: A Subaltern Empire in a Eurocentric World. Basingstone: Palgrave Macmillan.

Omyła-Rudzka, Małgorzata. 2016. Stosunek do innych narodów: Komunikat z badań, $n r$ 53/2016 [Attitudes to other nations: Research report no. 53/2016]. Warszawa: CBOS.

Ost, David. 2005. The Defeat of Solidarity: Anger and Politics in Postcommunist Europe. Ithaca: Cornell University Press.

Pełczyńska-Nałęcz, Katarzyna. 2017. A Farewell to Giedroyc. Warsaw: Stefan Batory Foundation.

Rojek, Paweł. 2009. Semiotyka Solidarności: Analiza dyskursów PZPR i NSZZ Solidarność 1981 roku [The semiotics of Solidarity: An analysis of the discourses of the United Polish Workers' Party and the Solidarity Independent Self-Governing Trade Union in 1981]. Kraków: Nomos.

Sierakowski, Sławomir. 2017. "The Five Lessons of Populist Rule.” The Daily Star, January 4. Accessed December 23, 2017. http://www.thedailystar.net/opinion/ project-syndicate/the-five-lessons-populist-rule-1339810

Snyder, Timothy. 2016. Black Earth: The Holocaust as History and Warning. New York: Tim Duggan Books.

Uchwała. 1991. Uchwała Sejmu Rzeczypospolitej Polskiej z dnia 31 sierpnia 1991 r. w sprawie niepodległości Ukrainy [Resolution of the Sejm of the Republic of Poland of August 31, 1991, concerning the independence of Ukraine]. Monitor Polski, 29, pos. 205.

Ukaz. 2013. Ukaz o merakh po povysheniiu effektivnosti deiatel'nosti gosudarstvennykh SMI [Decree on measures for increasing the effectiveness of the state-run mass media]. Kremlin.ru website, December 9. Accessed December 23, 2017. http:// www.kremlin.ru/events/president/news/19805

Umland, Andreas. 2017. "East-Central Europe's 'Galactic' Imagining of Post-Soviet Security.” Kennan Institute - Focus Ukraine, October 23. Accessed March 18, 2018. http://www.kennan-focusukraine.org/east-central-europes-galactic-imaginingof-post-soviet-security/

Vakarchuk, Sviatoslav [s_vakarchuk]. 2014. "Ne dyvit'sia na Ukraïnu iak na zemliu svoikh bat'kiv. Dyvit'sia na nei jak na zemliu svoikh ditei. I todi pryidut' zminy" [Do not consider Ukraine the land of your fathers. Consider it the land of your children. And then changes will come...]. Twitter.com website, October 24. Accessed December 23, 2017. https://witter.com/s_vakarchuk/status/525618614314209280 World Bank Data. 2017. Accessed December 23, 2017. http://data.worldbank.org/ indicator/NY.GDP.PCAP.CD? end=2015\&locations=DE-UA-PL-EU\&start=1989 


\section{Oleksiy Polunin}

ORCID 0000-0001-9058-3200

Kyiv National University of Trade and Economics

\section{TIME FLOW IN THE HUMAN MIND*}

\section{INTRODUCTION}

How do we introduce order to our personal and social experience? What is an essential component of all human plans, arguments and expectations? What do we rely on when judging causal relations? A crucial role in answering all these questions is played by the notion of time - namely, our cognitive representation of time flow. Usually, we rely on the conventional concept of singular time flow. This strong conventionality prevents us from raising the question whether the human mind is able to produce a number of various representations of time flow and whether we apply different representations of time flow in world modelling. Despite finding some deviations in intertemporal decision-making (Loewenstein 1988; Read et al. 2005), following conventionalities, we often ignore the fact that our mind is able to develop several cognitive representations of time flow,

* This article was written within a research project carried out in the "Artes Liberales" Institute Foundation and supported by a grant from the Open Society Institute in cooperation with the Eurasia Program of the Open Society Foundations. 
thereby diversifying our world picture and providing a ground for variability of our behavior.

The goal of the essay is to raise the question about representation of time in the human mind and the mind's ability to produce not one but several representations of time flow. It also discusses the relevance of multiple time representations for many fields of research. In presenting the arguments from different disciplines, we describe some of the singular representations of time flow. We then argue that these representations have different properties and differently impact the image of an object over time. The list of arguments for a multiplicity of time representations includes findings from linguistics, behavioral economics, ethnological studies and above all from experimental psychology. Combined, they make the idea of multiple time representations explicit and show its relevance for different branches of research, like intertemporal decisionmaking modelling, causality studies, studies on counterfactual thinking, and temporal logic.

A representation of knowledge in a multidimensional space encompasses the basic categories, including time, value, space, ${ }^{1}$ and others. The basic categories provide the way to explain numerous phenomena in both social and natural sciences. Time is one among these fundamental categories and modern Western thinking is hardly imaginable without its time concept and temporal dimension. But even the most basic categories and concepts have their own cognitive representations. Such

\footnotetext{
${ }^{1}$ Here the word "space" is used in two different meanings: (1) multidimensional space - an abstract concept, and later (2) just physical space.
} 
representations may vary from epoch to epoch and from culture to culture. Already the ancient Greeks display diversity in time concepts, as epitomized by the existence two Greek gods of time: Chronos as well as Kairos - god of lucky moments. Later, Chronos was taken as the basis for the concept of linear, uniformly flowing time that we are most familiar with. In today's philosophy, however, one can find at least three different models of time: eternalism, possibilism and presentism (Dainton 2001), while some philosophers argue for four concepts of time (Molchanov 1977). All of them take time as an essence external to the subject's mind and do not assume any break of singularity of time flow, even when time flow is denied altogether. The idea of singularity of time seems to be very strong and is additionally reinforced by a century-long convention with a number of successful applications in sciences and the humanities. We remember our personal past along a singular time flow axis, human history and economic development are described along the same time line, also the future developments are modelled along singular time flow - at least most of us think this way. Let us ask ourselves whether all of that relies on one and the same representation of time flow? Is our mind not able to develop a few different representations of time flow, so that it has a few temporal perspectives on past experience and a few perspectives on expected events? Would it not be profitable from an evolutionary perspective for a multitude of temporal world-pictures to widen the spectrum of behavioral outcomes and thus distribute the behavioral risks of the whole population? At the same time, considering the role of time as a metaphysical 
category, one has to be careful with its re-conceptualization. As a corner stone of our world-picture, time provides stability to our behavior in social and individual dimensions. When attempting to overturn this corner stone, one has to think about all kinds of consequences, because such a move influences our understanding of the world, usual explanations of the events, self-representation over time, and individual behavior.

How does one justify the thesis about the mind's ability to generate several various representations of time flow? The argumentation proceeds from the thesis that the experience of time flow is a product of information processing by the human mind. The human organism has no specialized sense organ for time perception, so the experience of time flow is created by the cognitive system. Afterwards, it is conceptualized, from simple immediate experience of time flow up to philosophical theories of time. We distinguish three levels of time representation: (a) an immediate feeling of time flow, which is manifested as specific, directly given experience in the stream of consciousness, (b) cognitive representation of time flow in the form of cognitive maps describing the temporal relations between objects, which are applied in behavior regulation, like planning, remembering, comparison and judgment, especially for regulation of intertemporal activities, and (c) the theoretical concepts of time, which, as the philosophical discussions show, also display certain diversity. The first, experiential level is given as the feeling of time flow that unfolds within subjective present time. Out of this segment of experience, the cognitive system develops a few cognitive schemata describing the temporal 
relations between objects. Such cognitive schemata make up an array of time flow representations, but conventionally each of them is labeled with one and the same word - "time." At the next, third stage, reflective thinking is applied to create theories of time. These differ essentially from one another and one may find their examples in the folk concepts of time, in philosophy, and in physics. I argue that at the second as well as the third stages one finds both multiple cognitive representations of time flow and different theories of time. Below I am going to present the arguments for multiple theories of time and, what is more important, the arguments for the multiple cognitive representations of time flow, which are in a way forerunners of the abstract time theories.

\section{ARGUMENTS FOR MULTIPLE REPRESENTATIONS OF TIME FLOW: TIME THEORIES IN PHILOSOPHY}

Up to a certain level, one may believe that the modern Western folk concepts of time are rationalized and quite successfully used derivatives of the old Greek gods Chronos and Kairos. The linear Chronos-time corresponds to deliberate thinking that is projected on a plane along singular abstract axis and it is the type of time which reflects extended acting based on the ability to pursue distant goals. The Kairos-time is an orientation on some situational, opportunistically used moment, on fortunate use or misuse of circumstances in one's own interest. Since we observe two resulting behavioral patterns - Chronos- and 
Kairos-like behavior - this alone allows us to speak about at least two time representations.

The multiplicity of time representations rests upon the mind's ability to reflect information in manifold ways. In philosophy, some claims can be seen as arguments for time as an outcome of the mind's activity. St. Augustine said time was not a thing in reality but existed only in the mind's apprehension of that reality. This goes along with the position that time is a kind of mental instrument created by the mind to help it interpret and model the outside world. Thus, already in medieval philosophy there are propositions that the mind creates the basic categories helping it adapt to the world. Later one finds doubts 312 about the reality of time also in the works by Baruch Spinoza, Immanuel Kant, G.W.F. Hegel, Arthur Schopenhauer, and John McTaggart. For instance, Kant argues that time is a pure form of intuition, inherent in our faculty of sense. Our contemporary philosopher Bas van Fraassen connects time to the mind's ability of reasoning (Fraassen 1985). Also the modern, 21st century German philosopher and physicist Brigitte Falkenburg argues that time is a construct of the mind (Falkenburg 2012). The idea of non-reality of time raises the question of how to perceive the theories of time. Are they theories of non-reality, abstract outlines of how one understands and applies to the world the product of the mind's activity, namely the category of time?

At the beginning of the 20th century, McTaggart argued that there was in fact no such thing as time, and that the perception of a temporal order to the world was a mere appearance (McTaggart 1908). His argument begins by distinguishing two 
ways in which positions in time can be ordered. First, positions in time are ordered by notions like $X$ days in the future, presently, $Y$ days ago. This way of time ordering, done in relation to the present moment, McTaggart calls the "A properties" or "A series." But he proposes also the B series, when the positions in time are ordered by two-place relations like $X$ days earlier than, $Y$ days later than, simultaneous with.

Paying honor to McTaggart's attempt to show the unreality of time, we have to make a few remarks. His approach looks like an attempt to explain some contradictions in the concept of singular time flow. Implicitly, he treats time as a receptacle, and shows the fallacies of such time concept. This is certainly an argument for the wrongness of the time concept but not necessarily for the unreality of time in the outside world. One may see in his A and B series just two different ways of representing or thinking about time flow, and the contradiction McTaggart mentions as arising simply from masking these two ways to represent time by the use of one word - "time."

Taking time to be a kind of container and describing temporal properties as the A and B series, he forgets about the subject, as if the described temporal relations were observer-independent. Having missed the role of the subject, he does not approach the question about the origin of time and the role of human cognitive system in this origin. In our understanding, the A series represents so-called general time flow, which is projected along an abstract line. The B series reflects the local time relations that may appear between any pair of events, independently of their position on the geometrical line. Moreover, we may suppose 
that the cognitive system processes such temporal information differently. At the very least, both the A and B series may be just two more simple forerunners of a later, internally-produced abstract concept of time, used for describing the events/objects in the world.

McTaggart argues that the B series alone does not constitute proper time flow. His reason for this claim is that change is essential to time, and since B-series positions are forever "fixed," whereas A-series positions are constantly changing, the B series without the A series does not involve genuine change. What he is missing is the fact that after the introduction of a subject moving in time, the B series is also not fixed. It becomes just a special case of the A series.

McTaggart also argues that the A series is inherently contradictory. The different A properties are incompatible with one another. For instance, no time can be both future and past. But again, it is as if someone ignoring the movement of a subject along the time line stated that no point could be both in front and behind. According to McTaggart, we never resolve the original contradiction inherent in the A series. Based on such contradictions, he concludes that time itself, including both the A series and the B series, is unreal. In doing so, he again looks at time as abstract singular receptacle with forever defined positions for the events. But what is more interesting from our point of view is that such attempts to declare the unreality of time uncover the role of the cognitive system as the creator of time experience, and as the developer of the time representations and time theories. 
We have already mentioned the different theories of time, like presentism, possibilism, and eternalism. Each of them models time flow in specific ways. But, astonishingly, none of them gives a real, rational definition of time. They describe in different ways how time flows, but without providing a satisfactory answer to the question about what time is. Is it possible to have a theory of time without knowing that? What kind of theory will it be, if time remains undefined? This is why one has to begin a study of time from an immediately given experience of time flow, which is real in its existence as such.

Discussing the reality of time, one has to pay attention to the reductionist approach presented by Aristotle and Gottfried Leibniz. The reductionist position states that time does not exist independently of the events that occur in time. Time is reduced to the temporal relations between events. Presented as argument for this position is a thought experiment whereby all things in the whole universe stop changing for a while. Would one notice time flow in this case? So, time flow is given to us through the change of objects, through their temporal relations. The question of whether there is time without change is closely tied to the question of whether time exists independently of the events, whether time is an independent entity. But in fact, it is about independence from the perceiving subject - i.e., the cognitive system. Looking for an answer, one may get an interesting hint from the studies by Paul Fraisse, who has shown that a sleeping subject may program his- or herself to awaken at a certain moment in the future (Fraisse 1985). This points suggests that the cognitive system is able to track time flow even in sleep, 
when the perception of the outside world is almost "switched off." Even in sleep, an internal world seems to be an essential precondition for time experience and for tracking one's own position on a possibly imagined time line.

On the other hand, the question may be posed whether one needs time to notice changes in the world? Would one notice change without having a notion of time and does one need change for noticing time - such is the circularity of conventional thinking. The answer to these questions depends on the ability to take a step away from the convention of time existence. Let us consider that there are some tribes in Africa and Amazonia that perceive changes in the world but do not 316 have a concept of time, as there is no such category in their thinking. Pursuing the idea of multiple representations of time flow, one may ask whether there is only one right way to describe changes. Obviously not. In physics, this answer is even more obvious after the introduction of the relativity theory. But temporal relations between objects may also vary in the human mind, as evidenced by the different behavioral responses to the same objects.

The epistemological argumentation for the reductionist position states that we could never have any reason to posit a period of empty time; and even if there were such a period, we would not have any way of knowing about either its existence or its length. Up to a certain level, this argumentation is in agreement with the fact that the human organism has no special receptors for time perception, so we cannot perceive the flow of time as such. But this forces us to look at an immediate experience 
of time flow as a product of our brain activity, as a functional outcome of the cognitive system.

The other view on time in philosophy exists since Plato. According to this position, time is seen also as a receptacle but a universal absolute one, an empty container in which things and events happen. Time as the receptacle of all things exists independently of what (if anything) is placed in it. One of the most successful implementations of this position is the classical physics as proposed by Isaac Newton, who has introduced the idea of mathematical time, uniform for all objects (Newton 1999). Introducing multiple representations of time flow at the level of mental representation, one has to recognize the immense historical success of Newtonian physics, which is built upon the idea of mathematical singularity of the flowing time. The great fruits it has brought on historical scale are associated with the time-based calculations in the classical mechanics and technical engineering. The same concept of time has been successfully used as instrument of research in economics and the humanities. But all these past successes must not condemn us to repetitive application of the old time concept in the future. There are other fruits we have not cropped so far. This is why we should have a re-conceptualization of time.

Both the reductionist (Leibniz) and absolutists (Plato, Newton) positions consider the problem from the perspective of time-world relations: whether time real or not, how it exists in the world or how the world events are given in the timereceptacle. Our approach considers the mind-world relation, and highlights the time problem from this perspective. Time 


\section{Oleksiy Polunin}

is thought of as just an intervening variable introduced by the mind to help itself survive in the world. Such understanding of time presumes the availability of an additional scale, equal for all objects, regarding which many events can be measured and brought into relation. This helps to organize such mental functions as, for instance, systematically ordered reflective remembering and future planning, and thus increases the predictability of at least some events in the permanently changing world. In this perspective, time is just a way the cognitive system emulates the relations among things: it establishes a temporal dimension to emulate the dynamic world and to improve control over its own thoughts and behavior. The introduction of time makes

318 behavior of the living organism more flexible, as it provides a way of spectating past experience and of representing the coming developments. It is also a new dimension for reflections regarding one's own person, a new dimension for the development of the self. Modern psychopathology clearly points to the exceptional interconnectedness between disorders of the self and disorders of time perception in schizophrenic patients. Stability of the self is strongly correlated with stability of time experience and with appropriate orientation in time (Scharfetter 1999).

The interpretation of time as an instrumental adaptive product of the cognitive system highlights also the problem of the now moment. After the general relativity theory one cannot speak about a global now moment. This is a position shared also by the modern philosophers and psychologists who argue for the absence of a universal now (Dorato and Wittmann 2015). If there is no global now, how can we be sure about 
a universal past-future division? Actually, this division has also lost its universality after the introduction of relativity theory. The vagueness of the past-future distinction is in fact one more argument for the multiplicity of time flow representations. Having accepted that there are a number of ways to divide the experience segment into the past, the now and the future, one faces its multiple temporal representations. Time becomes local in relation to the time-thinking cognitive system, and so we have to speak about local cognitive representations of time flow. Such locality has not only a spatial meaning, in the sense of a cognitive system located in a particular point in space, but it is a locality in every single possible dimension of temporal thought. As examples of such locality one can distinguish the representations of time flow from the first- and the thirdperson perspective, which nevertheless are both developed in one and the same cognitive system. These perspectives (1PP vs. 3PP), despite being developed by one cognitive system and even despite aiming to describe the same time interval, differ essentially. Such discrepancy between, for instance, a future moment taken from the first- and from the third-person perspective highlights just one of the many possible localities in the representation of time flow. If the general time flow exists only as a theoretical concept, we must make a step ahead and replace this no longer valid generality by a number of local time flow representations. Thus, one may speak about a kind of cognitive temporal multiverse which should be possible even in one mind.

When introducing multiple mental representations of time flow, it is worth asking whether time must be represented 


\section{Oleksiy Polunin}

by a single line. Accepting multiple representations of time flow, we should take into account the existence of multiple time lines with different metrics. Or at least one has to agree to apply different metrics along a time line that is single but depending on (a) an actual representation of time flow and (b) on experimental conditions, e.g., the varying probabilities of event occurrence. In this case one and the same segment of experience may be activated within different temporal metrics. Conversely, it is more appropriate to expect for each time flow to have its specific metric characterizing the change of an object over time.

The philosophical discussions on modularity of the mind also provide some arguments for multiple representations of time flow. Since being proposed by Jerry Fodor (Fodor 1983), the idea of modularity has grown, adding different branches: a theory of mind (Baron-Cohen 1995; Scholl and Leslie 1999) as well as models of: the module responsible for number processing (Dehaene and Cohen 1995; Dehaene et al. 2003), the sub-system for emotions (Öhman and Mineka 2001), the module for spatial orientation (Hermer and Spelke 1996), and others. We believe that a module for time processing must be also introduced in a similar fashion. In the same way as the module for space processing develops a number of representations of space, helping the person to take different perspectives on object location and showing different spatial relations, a module for time processing must be able to generate several representations of time flow. Similarly to the representations of space, one has to distinguish at least two separate representations of time flow: 
a self-related, or egocentric, and the holistic, so-called abstract, general time flow. Of course, other representations of time flow may also be developed by the cognitive system, for instance regarding the self and a third person. According to Steven Pinker, John Tooby and Leda Cosmides, the living systems with function-specific cognitive mechanisms should enjoy a priority in natural selection (Pinker 1997; Tooby and Cosmides 1992). These specific cognitive mechanisms increase the survival probability of organisms and populations. Therefore, the different specifically applicable cognitive representations of time flow should contribute to more sustainable existence of humans as a species.

Daniel Dennett and Marcel Kinsbourne contrast two models of consciousness in terms of their treatment of subjective timing (Dennett and Kinsbourne 1992): the standard Cartesian Theater model and the Multiple Drafts model. Without going into details, one has to look at these two models as two ways to represent the temporal relations between events in the stream of consciousness. According to Dennett and Kinsbourne, the Cartesian Theater model implies that the temporal properties of the content-bearing events occurring within the privileged representational medium determine subjective order. The Multiple Drafts model, in its turn, holds that none of the temporal properties "determine subjective order, since there is no single, constitutive 'stream of consciousness' only a parallel stream of conflicting and continuously revised contents" (Dennett and Kinsbourne 1992, 183). Agreeing with the authors regarding their preference towards the Multiple Drafts model, one can 
easily see some similarities between that model and the idea of multiple representations of time.

Thus, philosophy already proposes multiple theories of time, and therefore offers prerequisites for arguing for multiple cognitive representations of time flow. One cannot forget that as a human being, a philosopher is not separable from his or her own cognitive system. The reflective thoughts of a philosopher are based upon the functional features of the cognitive system, which already has multiple representations of time flow at least in implicit form. The mind's ability to represent time in many ways is given to us as multitude of time concepts. The theories of time proposed by philosophers and the thought-based arguments about the reality or non-reality of time are undoubtedly important. But below we are proposing arguments based on experimental studies and on observations of human behavior that urge us even further to recognize the mind's ability for producing multiple representations of time flow.

\section{MULTIPLE REPRESENTATIONS \\ OF TIME FLOW IN EXPERIMENTAL AND BEHAVIORAL SCIENCE}

Time representation is examined in linguistics when it analyzes the tenses. One may ask how helpful linguistics can be in arguing for multiple representations of time flow. The development of the communication system and the system supporting the timing of information processing go hand in hand through evolution and history. Both are the products of 
the cognitive system. Hence, up to a certain level, the peculiarities of time representation must be reflected by language, and the available representations of time flow should impact the ways tenses are given in language. The question is: what is the extent to which time flow can be correctly represented in language - or, is language able to reflect the complexity of cognitive time representation? One also has to consider the fact that language contributes to the development of time concept at the abstract level and is consequently responsible for some discrepancies between the world pictures of different nations speaking different languages (Chen 2013).

Taking into consideration the historical troubles, beginning from Aristotle, with answering the question of what time is, one should assume that it must be impossible to reflect our time experience in language in a singular way. Of course language reflects some of mental representations of time flow, but the question remains whether these reflections are accurate enough to rely on them in every case. As one of the simplest examples, we may point to the multitude of time moment representations in language. Below are some sentences regarding the now moment; from the logical perspective, at the moment of writing, each of these sentences is true. But some of the sentences become wrong in a second, some in a few hours or in a few days, and some remain true for a number of years:

Now is the 21st century.

Now is the second decade of the 21st century.

Now is the year 2017.

Now is the winter of 2017. 
Now is January 2017.

Now is Tuesday, the 31st of January 2017.

Now is the morning of the 31st of January 2017.

Now is exactly 9 o'clock in the morning on the 31st of January 2017.

In each of these sentences, the now is given properly but in one of the multiple possible ways. If the reader looks at the practical connotations of each of these phrases, he or she may get a feeling of how different they are. Thus, even such simple moment as the now can be reflected in language in many ways. One may list similar sentences for past or future moments. Heinz Vater describes the different ways of presenting a moment in the German language (Vater 2007). In English, too, there are several ways to describe the past and the future. For instance, speaking about the past, Hans Reichenbach points to the differences between the preterit and perfect that play the role of norms (Reichenbach 1947). The studies on time representation in linguistics by Vyvyan Evans also point to the multiple ways of representing time marks of an event in language (Evans 2005). We believe that such true but different presentations of the now, the past and the future, that are set in language as norms, highlight the diversities in cognitive grounds and constitute an argument in favor of multiple mental representations of time flow.

Kasia M. Jaszczolt, in her essay on the representation of time in language, tackles the question about how humans conceptualize time (Jaszczolt 2009). She analyzes how the information communicated by tense, aspect, and temporal adverbs interacts 
in the mind; how the concepts of the past, present and future appear therein. One of her positions is that these concepts are composed of more basic constituents. According to her view, temporality can be traced to degrees of certainty, understood as degrees of acceptability (the notion that "it is reasonable to think that" - Jaszczolt 2009, 142) concerning the eventuality referred to in the speaker's utterance. She believes that modality provides basic conceptual building blocks for the concept of time.

To sum up, in linguistics, one finds alternative ways of expressing information about the past, present and future events that in some cases play the role of norms and highlight the qualitative discrepancy between some representations of time. This may serve as an argument for the co-existence of a few different representations of time flow. If the concept of multiple representations of time flow is to be developed further, each of the single representations of time flow must get its specification with the list of corresponding properties and conditions of its application. We should introduce also a special verbal mark for each single representation. This last move helps to step out of the shadow of the general word "time" and to introduce separate calculations for an object's variation within each singular representation of time flow.

Arguments for multiple representations of time flow are also to be found in folk theories of time and the multiple representations of time flow in cultural studies. Different nations have different concepts of time that up to a certain level correlate with their lifestyles and beliefs. We are used to applying the western linear concept of time with the corresponding modes 


\section{Oleksiy Polunin}

of the past, present and future. But there are groups that do not have an explicit concept of time or have an essentially different one. One of such instances are Buryats that live in Russia, in the broadly understood Euro-Asian borderland. The Buryat culture may be seen as a variety of Mongolian culture and represents the Central Asian civilization. Ayur Zhanaev states that time is given in this culture metaphorically as whirl of events, a cycle (Zhanaev 2013). This metaphor is simplified to the more concrete notions like the year cycle, the wheel of the year, revolving prayer drum, and so on. Most of them are tightly connected to the repeating natural phenomena. Agreeing with Marina Sodnompilova, Zhanaev states that in the Buryat folk literature, one cannot find a word marking pure time as such (Sodnompilova 2009). The concept of time is given indirectly through the sequences and cycles of actions and places. Moreover, the concepts of the past and future are differently projected on space. For Buryats, the past is placed in front of the person, before the person. The past is something that you already know, that has happened and you can see it before your very eyes. The future is placed behind the person, so that one cannot see it. The future is unknown, one cannot know what it will bring, one cannot see what comes into the present life from behind one's back. Ludwig Wittgenstein said that facts were a construction of our minds (Wittgenstein 2001). Such conceptualization of the future must have had implications for the historical development of the Buryat people. It is exceedingly difficult to plan one's own future, perceiving it as an unknown that one cannot see. All that such groups have to rely on are the 
already known past and a cyclically repeated quasi-future. Such construct is at odds with the notion of intentionally planned progress and with the Western term, and notion of, "vision."

A list of other cultural differences and discrepancies in time representation and time perspectives is given by James Jones (Jones 1988). He believes that time representation is an essential characteristic of a culture and its analysis must precede any cultural comparisons. Knowing that goal-directed behavior follows from the temporal perspective, one should, correspondingly, look at the cultural differences in its definition. Noticing an interdependence of time, economics and social development, one should look for arguments supporting multiple representations of time flow also within behavioral economics. The latter field shows a clear discrepancy in behavior regarding monetary savings, investment, and healthcare depending on how future is represented in a language. Clear indications of the mind's ability to develop several cognitive representations of time flow can be found in an implicit form in the studies by M. Keith Chen (2013) and Daniel Read et al. (2005). Chen uses the fact that languages differ widely in the ways they encode time to prove the hypothesis that those languages that grammatically associate the future and the present foster future-oriented behavior (Chen 2013). According to him, the speakers of such languages "save more, retire with more wealth, smoke less, practice safer sex, and are less obese" (Chen 2013, 690). This finding holds true both across countries and within countries when comparing demographically similar native households. Read and his colleagues have shown that one 
and the same future monetary proposition but in one instance marked by a calendar date and in another by a point in time described as a time delay induces different preferences (Read et al. 2005). In conclusion, they state that the description of a temporal interval affects the discounting of a proposition. But while describing this paradox, they avoid an explicit assumption about the mind's ability to produce more than one representation of time flow.

As shown in the studies by Goerg Loewenstein and other studies on the temporal framing effect (Loewenstein 1988; Chandran and Menon 2004; Loewenstein and Elster 1992; Mazur 1987; Prelec and Loewenstein 1997), there are different ways to frame a decision in the temporal dimension. Consequently, time flow representation should show essential variations, influencing in significant ways human behavior and experience. Assuming the identity of all other conditions, if there is one and only one representation of time flow, this representation of time, being applied to one and the same object (money, a healthcare proposition, an investment), should result in one and the same behavioral outcome. But studies in behavioral economics highlight the diversity of behavioral outcomes, which, we believe, is often to be explained by multiple representations of time flow.

Another source of arguments for multiple representations of time flow is developmental psychology (Campbell 1994; Friedman 1991, 2005; McCormack and Hoerl 2008; McCormack and Hanley 2011). For instance, the representations of the past and the future first appear in different developmental phases and are quite independent from each other (Friedman 2005; 
McCormack and Hanley 2011). John Campbell has shown that in the developmental stage, a person has two ways of temporal orientation that are related to McTaggart's A and B series (Campbell 1994). One is temporal orientation with respect to the phase of action. The other - with respect to particular times. Also Teresa McCormack and Christoph Hoerl distinguish event-dependent and event-independent temporal thought in the development of mature temporal cognition (McCormack and Hoerl 2008). McCormack and Hanley show discrepancy between distinguishing the past and the future in child development (McCormack and Hanley 2011). The concept of the past is developed and used much earlier than the concept of the future. Their gradual, non-simultaneous development points to the different character of representations of the past and of the future that are later put together on one geometrical line which thereafter is called the abstract time line. Although the developmental psychologists do not mention the idea of multiple mental representations of time explicitly, they show that representation of time develops in steps and that each stage of development can be described by a certain relatively stable representation of time, which functionally serves the purpose of information processing and shapes specific individual behavior. Elsewhere we have shown that the adults also process a monetary saving proposition differently depending on whether this proposition begins in the past or in the future, as if they had different time lines for the past and the future (Polunin 2009, 2014). We argue that the mind of an adult person retains an array of all these developmentally early representations of time 


\section{Oleksiy Polunin}

flow. Under certain circumstances, he or she can activate one of the representations of time flow and use it to solve a certain problem (Polunin 2015). So, according to the need at hand, a single time representation can be taken out of the whole array, activated and applied quite independently from the other representations of time flow. Moreover, the array of time representations is structured not as a line but rather as a tree, and each branch of it finds its use under certain conditions, as we apply heuristics also in intuitive decision-making.

Possibly the strongest argumentation for the mind's ability to generate numerous representations of time flow is proposed by modern experimental psychology. Regularities in behavior are 330 at the heart of explanations given within the cognitive sciences. Most of them are found based on the concept of time. The mental time flow is a kind of modulator varying the intensity of particular stimuli. A stimulus's belonging to the present moment makes it the most intensive. A change of temporal distance to the stimulus impacts its intensity, and so - its value. On the other hand, thanks to multiple time representations, physically equidistant events may be subjectively perceived as if they were located at different distances. This happens because of their different metrics. Each cognitive representation of time flow is a kind of functional subsystem responsible for processing a certain type of temporal information. The properties of each time representation modulate the processing of the corresponding temporally distant stimulus. Thus, each of the time representations leads to a specific evaluation of stimuli and, as a consequence, to a specific behavioral outcome. 
Some of the studies underline the role of the perceiving subject and this, too, stresses the fact that the mind produces time experience (Van De Grind 2002). Since there is no specialized receptor for the passage of time, one can assume that time is constructed by the cognitive system itself. This position coincides with one expressed by James Gibson, namely that events are perceivable but time is not (Gibson 1975). Psychologists Ronald Gruber and Richard Block are inclined to present time flow as a kind of perceptual illusion, a product of information processing (Gruber and Block 2013). The numerous distortions in time processing that have been recognized as related to the processing of other aspects of information point to the fact that the mind is heavily involved in the development of the time flow experience (Terao et al. 2008; Xuan et al. 2007; Kanai et al. 2006; Eagleman 2005; Schiffman and Bobko 1974; Roelofs and Zeeman 1951). The representation of time and experience of time flow are constructed by the cognitive system as a ground for multisensory integration and for the integration of extended information within one sensual modality.

A number of experimental studies on the role of time representation in decision-making also point to the multiple cognitive representations of time flow (Polunin 2009, 2011a, 2011b, 2013, $2014,2015,2016)$. Our results show the existence of relatively independent representations of time flow: situational and propositional time flow, time flow modelled from the first- and the third-person perspective, and a number of other temporal processes. We argue that the mind itself generates the time flow experience and, moreover, shapes several representations 


\section{of time flow with different properties and different impact on} individual behavior. The characteristic properties of each of the cognitive representations of time flow specifically modulate the subjective value of an object over time. This results in significantly different decision outcomes regarding one and the same proposition as it is given within different representations of time flow. Thus, a switch from one time representation to another one impacts (a) the manifestation of human behavior, and (b) the establishment of regularities in human behavior.

One may look at the thesis about multiple representations of time flow from the perspective of survival probability of the whole population. The question at hand is: what is the 332 evolutionary purpose of a multitude of time representations? The cognitive system is just an evolutionary shaped part of an organism which strives to survive, and to ensure continuation of life. In this sense, the categories it produces - like the self, time, space, power, value, and God - are the instruments providing an improved world modelling, and so they are the instruments of survival for both individual organisms and the human species. It is more probable to survive in an environment which is modelled through a number of basic categories like time than in one which has no such description at all and therefore appears as absolutely alien, discontinuously dotted in its existence and unpredictable. The time-founded descriptions of environment allow for at least subjectively secure action as long as the subject follows his or her own emulation of the world. Based on the gained experience, the more successful descriptions of the environment are improved and transmitted further. 
The multitude of time representations provides a variability of responses to one and the same distant stimulus, and this helps to avoid blind alleys in behavior. Depending on actual representation of time applied for processing of certain stimuli, different groups in population show discrepancies in their behavior. Thus, through diversity of behavior, a higher survival probability is ensured for the whole population. That is the virtue of introducing multiple representations of time flow applicable to the processing of the same stimuli. While Dan Ariely and Dan Zakay interpret "time as medium within which decisions take place" (Ariely and Zakay 2001, 187), for us time is an instrument constructed by the cognitive system for helping itself in making diverse decisions. Time representation serves the purpose of modulating behavior and better adjusting to the environment.

\section{CONCLUSIONS AND PERSPECTIVES}

An array of convincing arguments from numerous disciplines points to the mind's ability to develop multiple representations of time flow with different features. This requires the corresponding reconceptualization of time, namely, a transition from the singular to the multiple time flow concept. In the humanities, including psychology and the other behavioral sciences, like economics, time should lose its unique conceptualization as a singular, universal flow which is uniform for all objects and situations. In fact, time dissipates into a number of separate time flow representations generated by the human cognitive system. The temporal perspective of an observer (scientist) 
gets a few additional dimensions. A researcher is enabled to regard a studied effect within different representations of time flow. The introduction of multiple time flows as a new variable should engender a paradigm shift. The fundamental character of the category of time makes such reconceptualization relevant for many fields of research: causation modelling, counterfactual thinking, temporal logic, theories of explanation, modelling of intertemporal decision-making, moral judgment of temporally distant events, temporal dimension of normativity, phenomenology of time reflection, and so on. Without aspiring to list all of the fields that may be touched by such paradigm shift, below we briefly highlight just some of them.

Studies on Subjective Truth

It may be argued that there is no truth, and no laws, outside of time. What, then, will be the impact on truth of the introduction of time multiplicity? One can interpret truth as correspondence with the facts. We have shown experimentally elsewhere (Polunin, 2009, 2014, 2015, 2016) that one and the same proposition, which can be taken as a fact, is differently perceived within different representations of time flow. An introduction of multiple time representations paves the way to multiple local truths and to the multiplication of the previously singular laws. This step might be described as the introduction of temporal localities, or domains, with their own laws and truths. We may assume that this should affect subjective judgment of truth. For instance, for one and the same object or event (A) taken at the same physical time moment ( $t$ ) 
but given in different time representations, one may conclude that $\mathrm{A}\left(\mathrm{t}_{\text {repr1 }}\right) \neq \mathrm{A}\left(\mathrm{t}_{\mathrm{repr} 2}\right)$.

\section{Causation Studies}

The introduction of multiple representations of time flow raises doubts about the causal closeness to the world, which should be of interest to physicists. A physicist being aware of the role of his or her own mind in the creation of time flow should provide a new perspective not only on the already created world picture but also on his or her own ability to diversify this world picture by relying on different representations of time flow.

Beside studies on causality in the physical world, one has the whole array of studies on subjective causality modelling. The temporally tagged events may provide a basis for causal relations (Nishida and Johnston 2002), so the connectedness of causation and time concepts is difficult to overlook. In the domain of social psychology, Harold Kelley's prominent studies (Kelley 1967, 1973) apply covariation calculus to causal attribution. Different patterns of consistency, distinctiveness, and consensus drive the causal attribution towards the actor, target, context or the "actor x target" interaction. One notices that each of these variables may be given within different representations of time flow, resulting in discrepant outcomes of causal attribution. In linguistics, the concept of implicit causality was extensively studied by Roger Brown and Deborah Fish (Brown and Fish 1983a, 1983b). Different representations of time flow can quite easily be introduced in their experimental schemata and consequently allow for examining how each of 
them impacts causal attribution. Bertram Malle's recently proposed concept of subjective causality presents causal attribution as a relatively complex tree which distinguishes causation and reasoning (Malle 2005). One may notice that in his model, too, the components of causal relations can be modulated by different representations of time flow. In fact, all three models of causal attribution have a temporal dimension. Thus, time representation can be introduced into each of these theoretical models as an additional independent variable. Such variable provides a ground for a number of further experimental studies, enabling the development of instruments influencing subjective causal attribution.

Temporal Logic

The time line provides an essential component of temporal logic. Every variation in the representation of time flow must result in a possible variation of the outcomes of logical operations. Up to now, the temporal logic proposed by Arthur Prior was based upon the conventional concept of singular time flow (Prior 1957; Øhrstrøm and Hasle 1995). Such logic helps to decide whether a sentence is true or false regarding the time dimension. It also finds important applications in the studies on artificial intelligence and in different aspects of computational modelling. Today, the conventional singular time flow representation provides a unique solution of any logical task regarding the time dimension. Taking into account the mind's ability to develop a number of time flow representations should foster further development of temporal logic. A truth outcome that was previously based upon the concept of singular time 
flow may be replaced by an array of "local" intertemporal truths. The essence of the introduction of multiple time representations into temporal logic consists in a multiplication of the possible outcomes of logical operations. Such a kind of new temporal logic should more appropriately model real human experience and behavior over time.

This by no means conclusive list of new problems and directions demonstrates that the proposed multiplicity of time representations provides a useful framework for further research in many different fields.

\section{REFERENCES}

Ariely, Dan, and Dan Zakay. 2001. "A Timely Account of the Role of Duration in

Decision Making." Acta Psychologica 108: 187-207.

Baron-Cohen, Simon. 1995. Mindblindness. Cambridge, MA: MIT Press.

Brown, Roger, and Deborah Fish. 1983a. "Are There Universal Schemas of Psychological

Causality?" Archives de Psychologie 51: 145-53.

Brown, Roger, and Deborah Fish. 1983b. "The Psychological Causality Implicit in

Language." Cognition 14: 237-73.

Campbell, John. 1994. Past, Space, and Self. Cambridge, MA: MIT Press.

Chandran, Sucharita, and Geeta Menon. 2004. "When a Day Means More than a Year:

Effects of Temporal Framing on Judgments of Health Risk." Journal of Consumer Research 31 (2): 375-89.

Chen, Keith, M. 2013. "The Effect of Language on Economic Behavior: Evidence from Savings Rates, Health Behaviors, and Retirement Assets." American Economic Review 103 (2): 690-731.

Dainton, Barry. 2001. Time and Space. Ithaca: McGill-Queen's University Press.

Dehaene, Stanislas, and Laurent Cohen. 1995. "Towards an Anatomical and Functional Model of Number Processing." Mathematical Cognition 1: 83-120.

Dehaene, Stanislas, Manela Piazza, Philippe Pinel, and Laurent Cohen. 2003. "Three Parietal Circuits for Number Processing." Cognitive Neuropsychology 20 (3-6): 487-506.

Dennett, Daniel, and Marcel Kinsbourne. 1992. "Time and the Observer: The Where and When of Consciousness in the Brain.” Behavioral and Brain Sciences 15: 183-247. 


\section{Oleksiy Polunin}

Dorato, Mauro, and Marc Wittmann. 2015. "The Now and the Passage of Time: From Physics to Psychology." KronoScope 15: 191-213.

Eagleman, David. 2005. "Distortions of Time During Rapid Eye Movements." Nature Neuroscience 8 (7): 850-51.

Evans, Vyvyan. 2005. The Structure of Time: Language, Meaning and Temporal Cognition. Amsterdam, Philadelphia: John Benjamins Publishing Company.

Falkenburg, Brigitte. 2012. Mythos Determinismus: Wieviel erklärt uns die Hirnforschung? Berlin, Heidelberg: Springer Verlag.

Fodor, Jerry. 1983. The Modularity of Mind. Cambridge, MA: MIT Press.

Fraassen, Bas C. van. 1985. An Introduction to the Philosophy of Time and Space. New York: Columbia University Press.

Fraisse, Paul. 1985. Psychologie der Zeit: Konditionierung, Wahrnehmung, Kontrolle, Zeitschätzung, Zeitbegriff. München, Basel: E. Reinhard.

Friedman, William. 1991. "The Development of Children's Memory for the Time of Past Events." Child Development 62: 139-55.

Friedman, William. 2005. 'Developmental and Cognitive Perspectives on Humans' Sense of the Times of Past and Future Events." Learning and Motivation 36: 145-58. Gibson, James. 1975. "Events Are Perceivable But Time Is Not." In The Study of Time II: Proceedings of the Second Conference of the International Society for the

Study of Time, Lake Yamanaka - Japan, edited by Julius T. Fraser and Nathaniel Lawrence, 295-301. Berlin: Springer.

Gruber, Ronald, and Richard Block. 2013. "The Flow of Time as a Perceptual Illusion." Journal of Mind and Behavior 34 (1): 91-100.

Hermer, Lind., and Elizabeth. S. Spelke. 1996. "Modularity and Development: The Case of Spatial Reorientation." Cognition 61: 195-232.

Jaszczolt, Kasia M. 2009. Representing Time: An Essay on Temporality as Modality. Oxford: Oxford University Press.

Jones, James M. 1988. "Cultural Differences in Temporal Perspectives: Instrumental and Expressive Behaviors in Time." In The Social Psychology of Time: New Perspectives, edited by Joseph E. McGrath, 21-38. Thousand Oaks: Sage Publications.

Kanai, Ryota, Chris L. Paffen, Hinze Hogendoorn, and Frans A. Verstraten. 2006. "Time Dilation in Dynamic Visual Display." Journal of Vision 6: 1421-30.

Kelley, Harold. 1967. "Attribution Theory in Social Psychology." In Nebraska Symposium on Motivation, edited by David Levine, vol. 15, 129-238. Lincoln: University of Nebraska Press.

Kelley, Harold. 1973. "The Processes of Causal Attribution.” American Psychologist 1: 107-28.

Levine, Robert. 2006. A Geography of Time: Temporal Misadventures of a Social Psychologist, or How Every Culture Keeps Time. London: Oneworld Publications. Loewenstein, Georg. 1988. "Frames of Mind in Intertemporal Choice." Management Science 34 (2): 200-214.

Loewenstein, Georg, and Jon Elster, eds. 1992. Choice over Time. New York: Russell Sage Foundation. 
Malle, Bertram, F. 2005. "Folk Theory of Mind: Conceptual Foundations of Social Cognition.” In The New Unconscious, edited by Ran R. Hassan, James S. Uleman, and John A. Bargh, 225-55. Oxford: Oxford University Press.

Mazur, James E. 1987. “An Adjustment Procedure for Studying Delayed Reinforcement." In The Effect of Delay and Intervening Events on Reinforcement Value, edited by Michael Commons, James Mazur, John Nevin, and Howard Rachlin, 55-73. Hillsdale: Lawrence Erlbaum.

McCormack, Teresa, and Mary Hanley. 2011. "Children's Reasoning about the Temporal Order of Past and Future Events." Cognitive Development 26: 299-314. McCormack, Teresa, and Christoph Hoerl. 2008. "Temporal Decentering and the Development of Temporal Concepts." In Time to Speak: Cognitive and Neural Prerequisites of Time in Language, edited by Peter Indefrey and Marianne Gullberg, 89-113. Malden: Blackwell Publishers.

McCormack, Teresa, and Christoph Hoerl. 2011. "Tool Use, Planning and Future Thinking in Children and Animals." In Tool Use and Causal Cognition, edited by Teresa McCormack, Christoph Hoerl, and Stephen Butterfill, 129-47. Oxford: Oxford University Press.

McTaggart, John, E. 1908. "The Unreality of Time.” Mind 17: 457-73.

Molchanov, Iurii B. 1977. Chetyre konceptsii vremeni v filosofii i fizike [Four concepts of time in philosophy and physics]. Moskva: Nauka.

Newton, Isaac. 1999. The Principia: Mathematical Principles of Natural Philosophy. Berkeley: University of California Press.

Nishida, Shin'ya, and Alan Johnston. 2002. "Marker Correspondence, Not Processing Latency, Determines Temporal Binding of Visual Attributes." Current Biology 12: 359-68.

Öhman, Arne, and Susan Mineka. 2001. "Fears, Phobias, and Preparedness: Toward an Evolved Module of Fear and Fear Learning." Psychological Review 108: 483-522. Øhrstrøm, Peter, and Per Hasle. 1995. Temporal Logic: From Ancient Ideas to Artificial Intelligence. Dordrecht: Kluwer Academic Publishers.

Pinker, Steven. 1997. How the Mind Works. New York: Norton.

Polunin, Oleksiy. 2009. "Temporal Dimension of Framing Effect in Topical Mental Accounting." Studia Psychologica 51 (4): 343-55.

Polunin, Oleksiy. 2011a. "Temporal Processes in the Topical Mental Accounting." Studia Psychologica 3: 275-91.

Polunin, Oleksiy. 2011b. "Relative Amount of Monetary Saving as a Factor of Proposition Aging and Elimination of the Framing Effect." Studia Psychologica, 4: 327-38. Polunin, Oleksiy. 2013. "Aging of Monetary Saving Proposition Formulated from the First- and the Third-Person Perspectives as Factor Modulating the Framing Effect." Studia Psychologica 55 (2): 123-38.

Polunin, Oleksiy. 2014. "The First- and the Third-Person Perspective on Monetary Saving Proposition Made in Future Time Mode." Studia Psychologica 56 (4): 253-65. Polunin, Oleksiy. 2015. "Cognitive Representation of Situational and Propositional Time Flow as Basis for Temporal Framing Effect in Future Time Mode." Studia Psychologica 57 (1): 5-20. 
Polunin, Oleksiy. 2016. "An Impact of the Situational and Propositional Time Flow on the Monetary Saving Proposition Made from the First- and the Third-Person Perspective." Studia Psychologica 58 (3): 171-83.

Prelec, Drazen, and Georg Loewenstein. 1997. "Beyond Time Discounting." Marketing Letters 8: 97-108.

Prior, Arthur. N. 1957. Time and Modality. Oxford: Clarendon Press

Read, Daniel, Shane Frederick, Burcu Orsel, and Juwaria Rahman. 2005. "Four Score and Seven Years from Now: The Date/Delay Effect in Temporal Discounting." Management Science 51 (9): 1326-35.

Reichenbach, Hans. 1947. Elements of Symbolic Logic. New York: The Free Press.

Roelofs, C. Otto, and Willem P. C. Zeeman. 1951. "Influence of Different Sequences of Optical Stimuli on the Estimation of Duration of a Given Interval of Time." Acta Psychologica 8: 89-128.

Scharfetter, Christian. 1999. Schizophrene Menschen: Diagnostik, Psychopathologie, Forschungsansätze. Weinheim: Psychologie Verlags Union.

Schiffman, Harvey R., and Douglas J. Bobko. 1974. "Effects of Stimulus Complexity on the Perception of Brief Temporal Intervals." Journal of Experimental Psychology 103: 156-59.

Scholl, Brian, and Alan Leslie. 1999. "Modularity, Development and 'Theory of Mind."” Mind and Language 14: 131-53.

Sodnompilova, Marina Mikhailovna. 2009. Mir v traditsionnom mirovozzrenii i prakticheskoi deiatel'nosti mongol'skikh narodov [The world in the traditional perception and practical activities of Mongolian peoples]. Ulan-Ude: Izdatel'stvo BNTs SO RAN.

Terao, Masahiko, Junji Watanabe, Akihiro Yagi, and Shin'ya Nishida. 2008. "Reduction of Stimulus Visibility Compresses Apparent Time Intervals." Nature Neuroscience 11 (5): 541-42.

Tooby, John, and Leda Cosmides. 1992. "The Psychological Foundations of Culture." In The Adapted Mind: Evolutionary Psychology and the Generation of Culture, edited by Jerome H. Barkow, Leda Cosmides, and John Tooby, 19-136. Oxford: Oxford University Press.

Van De Grind, Wim. 2002. "Physical, Neural and Mental Timing." Consiousness and Cognition 11: 241-64.

Vater, Heinz. 2007. Einführung in die Zeitlinguistik. Trier: WVT; Wissenschaftlicher Verlag. Wittgenstein, Ludwig. 2001. Philosophical Investigations. Oxford: Blackwell Publishing. Xuan, Bin, Daren Zhang, He Sheng, and Chen Xiangchuan. 2007. "Larger Stimuli Are Judged to Last Longer." Journal of Vision 7: 1-5.

Zhanaev, Ayur. 2013. 'Kontsept 'vremia' v traditsionnoi buriatskoi kul'ture i vektory izmenenii ego vospriiatiia $v$ kontekste pogranich'ia Evro-Azii” [The concept of time in traditional Buryat culture and the vectors of variation of time perception in the context of the Euro-Asian borderland]. In Debaty Artes Liberales, vol. 7, edited by Zoja Morochojewa and Vera Soloviova, 130-47. Warszawa: Wydawnictwo Wydziału “Artes Liberales” Uniwersytetu Warszawskiego. 


\section{Inna Sukhenko}

ORCID 0000-0003-1295-2271

Oles Honchar Dnipro National University

\section{LITERARY CHERNOBYL \\ AS A FACTOR OF ECOLOGICAL \\ IDENTITY FORMATION: \\ THE CASE OF UKRAINE}

At the time of the Nuclear Anthropocene (Ele Carpenter), the global environmental theory challenges us to develop new concepts, approaches, principles and toolkits that foster a new thinking within environmental humanities. Their goal, as inspired by a renewed impulse coming from the environmentcentered thought, is to foster the search for an identity that is about our own perception and our relation to "the Other" within the tightly-linked "nature-human-science" paradigm. Environmental humanities ought to provide a space where humanistic accounts of political representation and ethical recognition can be considered in regard to other species, and "social identities are studied in relation to conceptions of the natural, the animal, the bodily, place, space, landscape, risk, and technology, and in relation to the material distribution of environmental hazards and pleasures" (White 2010, 287). 


\section{Inna Sukhenko}

The renewed role of technologies and science within existing paradigms encourages transformations of environmental humanities' focus in the face of the current climate change, political instability and global governance. This is best viewed as part of the process of forming a new category of human identity - namely, ecological identity. Ecological identity reflects the diversity of ways in which a person is aware of himself or herself and shapes his or her own perception of the environment within the Nuclear Anthropocene. The knowledge and experience that form the person's ecological outlook ultimately cause a rethinking of memories, events and circumstances of his or her personal life - a process known as "ecological identification." That, in turn, results in personality changes, shaping a new attitude to the environment and forming an active social position concerning the issues of nature conservation. This vision moves from a simple sense of locality to that of bioregionalism, the basic idea of which is that every region is generally self-sufficient and much more focus should be given to a local sense, a sense of place, with less emphasis on national identity (Booth 2012, 67). As regards terminology, environmental humanities provide a range of terms to describe this type of identity, among which are "environmental identity," “ecological identity," “ecological self” etc. (Wanner 1998; Hundorova 2013; Plokhy 2018)

In this paper, I offer an overview of theoretical approaches to the issue of "ecological identity," which will provide a background for interpreting this type of identity within the Chernobyl discourse and allow me to argue that it is the writing 
about Chernobyl that encourages the narrative implementation of the Chernobyl accident, shapes the symbolic fulfillment of postChernobyl Ukrainian literature ("post-traumatic Chernobyl narrative," post-travmatychnyi Chornobylskyi narativ) (Hundorova 2012, 36), emphasizes the transformations of Ukrainian writing after the catastrophe, and results in a reconsideration of the Ukrainians' ecological identity based on Chernobyl "postcatastrophic" consciousness (Hundorova 2012, 36) within the post-traumatic society.

In 1949, Aldo Leopold, in his A Sand County Almanac, observed that people working closely with nature developed particular convictions and values with respect to the land, a phenomenon which he described as a "land ethic" (Leopold 1949). In his formulation, land ethic is centered around the idea that "all non-humans and all ecosystems should be treated ethically, because they're entities with rights, not just charactersof-our-own-devising” (Leopold 1949, 11).

Constantly living in, or regularly visiting, the same locations, humans develop a strong connection, even affinity, with the place - "the sense of place" - related to the development of localized understanding of their dwelling through constantly learning the local environment. Margaret Gooch (Gooch 2002) emphasizes the sense of place as a strong agency in identity formation and stresses the deep and personal connection with a definite place that it involves - "developing and maintaining (ecological) identity, and the related issue of identification with a specific place" (Gooch 2002, 4). Ecological identity centered on a particular place can be acquired through the development 


\section{Inna Sukhenko}

of shared values, beliefs and interests of the humans, which are shaped over time by way of collective experiences. The process of self-identification with a definite place is also closely related to the development of local knowledge. In view of all this, ecological identity is best sought within a common engagement through identification with the elements of a particular local environment (Tereshina and Bashmakov 2017, 10). These steps result in shaping a profound ecological consciousness, where ecological identity of humans refers them to the values of the locality and the measures of caring about the local environment; in other words, where humans consider themselves as equal partners within the local ecosystem.

Ecological Identity: Becoming a Reflective Environmentalist by Mitchell Thomashow (Thomashow 1995) is the milestone book in this field of environmental studies related to the issues of ecological identity formation. Thomashow defines ecological identity as "all the different ways people construe themselves in relationship to the earth as manifested in personality, values, actions and a sense of self. Nature becomes an object of identification" (Thomashow 1995, 3). The scholar clearly demonstrates that all the aspects of environmental studies, as well as environmental humanities, can significantly depend on personal reflection. It was due to his work that the notion of environmental identity could be formulated and gain traction. Answering the questions: What do I know about the place where I live? Where do things come from? How do I connect to the Earth? - a person can identify himself/herself as a being within the environment, and at the same time learn from it. Answering 
all these questions can launch the process of developing a sense of "the self" as a human being within natural and social ecological systems in close connection with their other components (Thomashow 1995, 15).

By postulating for nature to "become an object of identification" for the self, Thomashow defines ecological identity as a reflexive process of recognizing the self as one that is ecologically embedded and constructed through interactions with human and non-human phenomena: a result of a confluence of factors, including "perception of the ecosystem," and the direct, embodied experience of the environment (Thomashow 1995, 3). Thomashow stresses that ecological literacy complements ecological identity so well because both are based on the place, "where people learn about nature, the importance of direct experience, the clarity of a reflective orientation" (Thomashow 1995, 175). A deep caring for landscapes and a sheer sense of wonder and delight gained from nature-based experiences are all integral to ecological identity.

The complex of ecological identity in its individual dimension is raised in The Universe Story from the Primordial Flaring Forth to the Ecozoic Era: A Celebration of the Unfolding of the Cosmos by Brian Swimme and Thomas Berry (Swimme and Berry 1992). The authors claim that ecological identity is distinguished and fostered in the process of becoming "fully human." According to their opinion, eco-identity is an important component of shaping a human's selfhood. "While being fathers, mothers, professors, artists, players, activists," they say, "we are 'earthlings.' The amalgamation of all just mentioned roles 


\section{Inna Sukhenko}

makes the identity. ... [In ecological identity] the individual 'self' can find its complex understanding concerning a family's self, a community's self, earthly self, and the Universe's self" (Swimme and Berry 1992, 268). The importance and topicality of eco-identity formation result from the urgent character of realizing the ways of communing with the environment without exploiting it. This includes working out a way of reconsidering "human-nature" relations. Swimme and Berry state that this definite historical moment - the moment of entering a new geological era, called the "Ecozoic era" - is when the Earth calls out to us to initiate a new ecological beginning, leading to a resacralization of Nature itself. And this new era demands 346 us to launch the formation of eco-identity.

The subsequent volume Ecopsychology: Restoring the Earth, Healing the Mind, edited by Thomas Roszak and others (Roszak, Gommes, and Kanner 1995), greatly promoted the idea of ecological identity formation, while connecting it with the human's psychological health - both individual and collective. The volume provides the basis for realizing that the natural world enters our minds and subconscious and is not limited to our surrounding environment.

In 1998, a team of environmental activists (headed by John Seed) published Thinking Like a Mountain: Towards a Council of All Beings (Seed et al. 1998). According to one of the authors, Joanna Macy, renewing attitude towards the environment demands a renewed spiritual outlook. She stresses the idea about the mutual interconnections of everything within the environment, which in part results from her religious beliefs - Buddhism 
in particular. Macy emphasizes that it is human attitude - mainly a self-centered as well as anthropocentric one - that ruins the environment (cf. Verhagen 2010). The authors stress the idea of avoiding the dominating role of human beings as the initial stage in the process of shaping and developing the category of ecological identity (Seed et al. 1998).

A significant contribution to defining ecological identity as a component of human identity in the age of the Anthropocene has been made by Susan D. Clayton (Clayton 2003, 2012). She writes that under contemporary "green" initiatives and "sustainable development" policies, a human can develop so-called "ecological" (environmental) identity, defined by her as a sense of interconnection with some non-human environment, which affects the ways of our perception of and behavior towards the world. She also adds that ecological identity is our belief that the environment is an important part of the common unity (Devine-Wright and Clayton 2010, 267).

The author notes that the sources of identity can be numerous and include a person's values, social affiliation and property. Based on these categories, Clayton raises the issue of the urgency and importance of the environment in terms of ecological identity formation. She emphasizes the role of ecological identity as a source of a range of psychological meanings that involves the implementation of personally meaningful motives, which are nevertheless distinguished by their social and political significance (Devine-Wright and Clayton 2010, 267).

Clayton stresses that the concept of ecological identity combines two aspects: on the one hand, emotional intimacy and 


\section{Inna Sukhenko}

identification with nature, on the other hand - environmental focus of behavior. She points out that "identity is both a product and coercion: the set of beliefs regarding the personality (self), and a coercion for a specific way of interaction with the world" (Clayton 2012, 164). The ecological identity as an encouraging force can have a significant impact on the direction of personal, social and political behavior (Clayton and Kilinç 2013, 312).

A variety of research perspectives have shown that a human's ecological identity has important implications for pro-environmental attitudes and environmental behaviors, such as energy efficiency (Clayton and Opotow 2003), green consumerism (Sparks and Shepherd 1992, 388), recycling (Mannetti, Pierro, and Livi 2004), and environmental activism (Fielding, McDonald, and Louis 2008). Some of these perspectives also emphasize the inclusion of nature within the human's cognitive representations of the self (Schultz et al. 2004).

$$
* * *
$$

The explosion at the Chernobyl nuclear power plant (April 26, 1986) became not only the milestone of ecological memory for the Ukrainians but also an element of national identity, which affected the Ukrainians' national values, social affiliation, and ethical frames. As a result, Ukraine's ecological identity is based on a definite historical event and its wider connotations for the paradigm of "human-nature" relations. Chernobyl influenced and clarified the diverse aspects of the "nature-human-society" relationship. It also happened to be an impulse for the Ukrainian ecological identity formation. Chernobyl is considered to be 
a source of psychological meanings and ways of realization of personally meaningful motives, distinguished by their social and political significance.

Any description of links between the environment and Ukrainian culture needs to distinguish between the two major parts of Ukraine's twofold character. One has to do with the physical environment and corresponding ethnic traditions, which can be defined as "the eco-ethnic complex" (Ermolaev, Levtsun, and Denisenko 2011, 63). These eco-ethnic factors result in a conflict between the industrialization process in Ukraine and historically/ethnically-rooted nature-centered spirituality. The tensions between industrialization and nature adoration are the essence of the contemporary environmental predicament in Ukraine. Relations with nature are among key aspects impacting the specific ethnic character, regarded as a set of social and psychological features (feelings, values, psychological intentions, emotions, etc.) that are determined by social, economic, historical as well as geographical factors, that find their manifestations in the ways a society functions, and that are discernible in culture, traditions, and customs. The specific features of Ukrainian ethnic character include individualism, introversion, tolerance, and emotional abundance, the complex combination of which influences the formation of Ukrainians' eco-consciousness as well as the course of further development of the country's economy and industrial activity (Ermolaev, Levtsun, and Denisenko 2011, 63).

In the post-Chernobyl era, the ecological situation in Ukraine frames the dynamics of ecological culture formation 


\section{Inna Sukhenko}

of the Ukrainian society. Ukrainian ecological culture certainly includes profound knowledge about the environment and its components, as is evident in the agricultural system, the reliance on the seasonal calendar even in 21 st century urban settings, nature's impact on folk art and folk medicine, and the poetic images in Ukrainian folklore (Fialkova 2001, 182)

These are only a few examples that demonstrate how various kinds of ecological knowledge systems continue to permeate Ukrainian culture, even as the society confronts challenges of industrialization and economic development. Ukrainian culture has always been greatly influenced by its natural environment. Its folk wisdom preserves and transmits a caring attitude toward nature, based on a practical, rational understanding of how best to use the natural resources. The Ukrainians have traditionally not confronted the environment; on the contrary, they have always had an emotional attachment to the natural world and a respectful attitude toward Nature, regarding it as being of equal, or even superior, status. Despite the Ukrainian worldview's changes in recent decades, the Ukrainian culture is characterized by its tight, unbreakable links with the environment throughout history (Tahlina 2004, 42).

Ukraine's ecological culture has shifted its trajectory of development from an agricultural focus to a technological one. This parallels a transition from the nature-centered beliefs of pre-Christian Slavs, through the theologically-centered principles of Christianity and anthropocentric attitudes toward nature that were typical of Ukraine when it was a part of the totalitarian Soviet state, to the current newly restored nature-centered 
ecological ethics. The recent formation of ecological ethics is based on a new awareness of the Earth as a crucial life-support system, on up-to-date science, and on contemporary religious beliefs as well as other cultural components, including economic demands. Due to the latter circumstance, in thinking about the development of Ukrainians' new ecological consciousness, it is necessary to pay special attention to the economic causes of both contemporary ecological crises and environmental policy formation, taking into account that the rise of consumption in the anthropogenic environment is based not on the environmental resources but on human needs and wishes (Sukhenko 2014, 118).

The ethical aspects of human relations with the environment in the context of Ukrainian cultural tradition shape the moral principles of "human-nature" relations in the Ukrainian worldview. According to Andreieva (Andreieva 2000, 201-12), historically, the Ukrainians adhered to a sophisticated system of environmental values. A fundamental love and adoration toward nature is a central trait of Ukrainian mentality. Its widely shared Slavic religious beliefs emphasized a non-dualistic understanding of the relationships between humans and the non-human world, and stressed the equal value of all living creatures. The fact of adopting Christianity as well as Western European philosophical ideas encouraged a sense of humans' dominant role in human-nature relations in what has come to be the ecological identity of contemporary Ukraine. Christianity, with its clearly defined anthropocentric perspective, justified these dualistic principles in "human-nature" relations. Due to the ecologically 


\section{Inna Sukhenko}

insensitive Christian philosophy, environmental adoration began to be substituted with a more rational, and exploitative, approach towards the environment. At the same time, Christianity, as practiced in Eastern Europe, called for responsibility not only in interpersonal relations but also in human relationships toward natural phenomena (Andreieva 2000, 202).

Chernobyl as a factor shaping Ukraine's ecological identity demonstrates the way that the national (including social and political) components result from the set of characteristic features of individual humans. While Ukrainian ecological identity is based on bioregionalism and environmentalism, the Chernobyl narrative can also be considered as a background for shaping ecological identity in Ukraine. Initially, the eco-slanted social movements it generated dealt with the post-disaster events (supporting those who had suffered in the disaster and the forcefully resettled population, demanding protection for the surviving, radiated nature), but subsequently they fostered in their members "a politicised aspect of a personal identity trait or a politics of the self" (Light 2007, 59)

The Chernobyl narrative shaped an identity that was an amalgamation of those politically-colored activities - which challenged the hegemony of science and of humans and the power of decision-making structures (concerning both the Reactor and mainly the Exclusion Zone) - and of movements of cultural identity. Thus, all these features of ecological identity, manifested in personalities, values, actions and senses of the self, resulted in the situation in which people construed themselves in relationship to the Chernobyl disaster, and the Chernobyl 
narrative and literary Chernobyl itself became an object of identification.

The explosion at the Chernobyl nuclear power plant became an impetus to create literary works that profoundly reconsidered the scientific discoveries and achievements. The Chernobyl accident produced a peculiar surge of ecologically-directed publications and enabled the appearance of "ecological non-fiction/ documentaries" (so-called "writings on ecological affairs") and "ecological memoirs" (representing the "writer's ecological approach"). Ukrainian writers' responses to the nuclear accident were extremely dynamic; among them are documentary/nonfiction works such as Iurii Shcherbak's Reasons and Consequences (Shcherbak 1986) and Chernobyl (Shcherbak 1989), Volodymyr Iavorivskyi's Maria with Wormwood at the End of the Century (Iavorinskyi 1988), Ivan Drach's Chernobyl Madonna (Drach 1988), Borys Oliynyk's Seven (Oliinyk 1988), Lidia Viryna's Shadows of a Fiery Night (Viryna 1989) and Svitlana Iovenko's A Woman in the Zone (Iovenko 1996). Chernobyl as a subject of new literary works inspired them and others (Borys Oliinyk, Iurii Shcherbak, Vitalii Iavorivskyi, Liubov Syrota, Ivan Drach and Lina Kostenko) to devote their literary works to this disaster. But the critics' responses to these and other works were restrained and low-key. Sometimes a newly published work went by unnoticed.

Rereading the written responses to the Chernobyl catastrophe through the prism of ecological identity and its transformations allows to differentiate several ways in which ecological identity emerges in the Chernobyl literature. Firstly, it manifests itself 


\section{Inna Sukhenko}

in dialogues between "the self" before and after the Chernobyl accident, as "the characters come to terms with loss: loss of loved ones, loss of health, loss of home" (Tishler 2006, 89); secondly, the theme of identity also includes interpretations of "nature-human-acience" relations within the time span of the Soviet Union and the post-Soviet period (so-called "politicized Chernobyl"); the third aspect of revealing the ecological identity transformations is through framing the image of a "Chernobyl victim" and revealing the victim-culprit opposition in the postChernobyl (post-apocalyptic) age. (Here we should mention that Tamara Hundorova (Hundorova 2012) insists on avoiding the theme of victimization in rereading the Chernobyl narrative because the search for victims and their portrayal can result in unbalanced subjectivity and an overly dramatic interpretation of the disaster (Hundorova 2013, 10).)

Reconsidering the catastrophe as a factor shaping Ukrainian ecological identity, people in Ukraine started to recognize Chernobyl in its literary implications as the lost paradise, as a part of "private historical memory," as an unhealthy fascination, and even as a litmus test that showed the attitude of the authorities towards their own society both in the 1980s and even in the time before the 2013/2014 Maidan (Korzeniowska-Bihun 2017).

One of the ways identity can be revealed is through difference (Neumann 1999; Rumelili 2004) - especially, a radical difference: between "the self" and "the other," "the enemy" and "the friend" (Andreouli 2010; Oyserman, Elmore, and Smith 2012). In the Ukrainian context, this radical difference is demonstrated through the binary opposition "before/after Chernobyl." Thus, 
Tamara Hundorova, in her monograph The Post-Chornobyl Library: The Ukrainian Literary Postmodernism, emphasizes that Chernobyl gave birth to a new era in Ukraine's national identity - it launched not only postmodern literature but a new postmodern consciousness, as well (Hundorova 2013, 10). This perspective of studying Ukrainian ecological identity emphasizes the interpretations of the Chernobyl discourse within ecological post-traumatic culture (Hundorova 2013, 15). As Hundorova stresses, the Chernobyl explosion divided the history of Ukraine into "pre-Chernobyl" and "post-Chernobyl" stages (referring the latter to the post-apocalyptic time), and even more, as she says, Chernobyl literature encourages transformations of Ukraine's national culture, changing the way national identity is shaped, they way "the Other" is received, and giving rise to "the post-Chernobyl text," which interprets the world culture as an intertext of the Nuclear Age (Hundorova 2013, 17).

According to Mikhail Kolesnikov, considering the correlation between "ecological culture" and "ecological competence," we should stress that ecological identity can be regarded as a step forward from the simple level of increasing the ecological literacy towards the process of shaping a person as a subject of ecological culture in the system comprising "ecological literacy - ecological education - ecological competence - ecological culture - ecological mentality" (Kolesnikov 2013, 72).

Studying literary Chernobyl as a factor of ecological identity formation within Chernobyl narration studies correlates with the acute issues in environmental humanities. This aspect of the research tackles issues at the intersection of the humanities 


\section{Inna Sukhenko}

and science, while regarding Chernobyl in terms of political representation as well as ethics. Thus, ecological identity is studied in its relation to the concepts of "the environment," "technology," "abandoned city," "the Exclusion Zone," "Atom for Peace" as well as "nuclear energy" in its relation to the material distribution of environmental hazards.

In the Ukrainian context, identity studies remain in close connection with the cultural, political and social meanings directly associated with the environmental debate surrounding Chernobyl in its literary representation. The multidisciplinary debate allows the contemporary eco-centered studies to examine the historical event in its intimate relation with what is often the subject-matter of just the human sciences, animal studies or technological studies, all the while stressing the development and maintenance of identity, and the related issues of identification with the place and its history.

Bringing research and writing in environmental philosophy, ethics, cultural studies, and literature under a single umbrella not only gives an opportunity to reread the Chernobyl disaster and to reconsider ecological identity within environmental humanities, but also fosters debates about "soft nuclear diplomacy" in Central/Eastern Europe.

\section{REFERENCES}

Andreouli, Eleni. 2010. "Identity, Positioning and Self-Other Relations." Papers on Social Representations 19: 14.1-14.13.

Andreieva, Tetiana. 2000. Rozvytok moralnykh zasad vidnoshennia "liudyna-pryroda" $\mathrm{v}$ ukrains'komu svitohliadi [The development of moral principles in the aspect of 


\section{LITERARY CHERNOBYL AS A FACTOR OF ECOLOGICAL IDENTITY...}

"human-nature" relations in Ukrainian world perception]. Multiversum: Filosofs'kyi al'manakh 1: 201-12.

Aronowitz, Stanley. 1992 "Reflections on Identity." The Identity in Question 61: 91-103.

Booth, Kelvin J. 2012. "Environmental Pragmatism and Bioregionalism." Contemporary Pragmatism 9 (1): 67-84. Accessed June 20, 2018. http://www. northeastbioregionalnetwork.org.au/docs/Bioregionalism.pdf

Clayton, Susan D. 2003. "Environmental Identity: A Conceptual and an Operational Definition." In Identity and the Natural Environment, edited by Susan D. Clayton and Susan Opotow, 45-65. Cambridge, MA: MIT Press.

Clayton, Susan D. 2012 "Environment and Identity." In The Oxford Handbook of Environmental and Conservation Psychology, edited by Susan D. Clayton, 164-80. Oxford: Oxford University Press. Accessed January 15, 2018. http:// www.oxfordhandbooks.com/view/10.1093/oxfordhb/9780199733026.001.0001/ oxfordhb-9780199733026

Clayton, Susan D., and Ahmet Kilinç. 2013 "Proenvironmental Concern and Behavior in Turkey: The Role of National and Environmental Identity." PsyEcology 4 (3): 311-30.

Clayton, Susan, Amanda Koehn, and Emily Grover. 2013. "Making Sense of the Senseless: Identity, Justice, and the Framing of Environmental Crises." Social Justice Research 26 (3): 301-19.

Clayton, Susan D., and Susan Opotow. 2003. "Introduction: Identity and the Natural Environment." In Identity and the Natural Environment, edited by Susan D. Clayton and Susan Opotow, 1-24. Cambridge, MA: MIT Press.

Dawson, Jane I. 1996. Eco-Nationalism: Anti-Nuclear Activism and National Identity in Russia, Lithuania, and Ukraine. Durham: Duke University Press.

Devine-Wright, Patrick, and Susan Clayton. 2010. "Introduction to the Special Issue: Place, Identity and Environmental Behavior." Journal of Environmental Psychology 30 (3): 267-70.

Drach, Ivan. 1988. "Chornobyl's'ka Madonna” [The Chernobyl Madonna]. In Ivan Drach, Khram sontsia, 11-57. Kyiv: Radzians'kyi pys'mennyk.

Ermolaev, Andrei, Aleksandr Levtsun, and Sviatoslav Denisenko. 2011. Ukrainskii kharakter: Kharakternye sotsial'no-psikhologicheskie osobennosti naseleniia Ukrainy: Analiticheskiy doklad [The Ukrainian character: Characteristic sociopsychological traits of the Ukrainian population: An analytical survey]. Kyiv: Sofiia.

Fialkova, Larisa. 2001. "Chornobyl's Folklore: Vernacular Commentary on Nuclear Disaster." Journal of Folklore Research 38 (3): 181-204.

Fielding, Kelly S., Rachel Mcdonald, and Louis R.Winnifred. 2008. "Theory of Planned Behaviour, Identity and Intentions to Engage in Environmental Activism." Journal of Environmental Psychology 28 (4): 318-26.

Gooch, Margaret. 2003. "A Sense of Place: Ecological Identity as a Driver for Catchment Volunteering." Australian Journal on Volunteering 8 (2): 23-32. Accessed June 25, 2018. http://citeseerx.ist.psu.edu/viewdoc/download?doi=10.1.1.464.4691\&rep $=$ rep $1 \&$ type $=$ pdf 


\section{Inna Sukhenko}

Hinds, Joe, and Paul Sparks. 2009. "Investigating Environmental Identity, Wellbeing and Meaning." Ecopsychology 1 (4): 181-86. Accessed June 25, 2018. http://shura. shu.ac.uk/5398/1/HindsSparks2009.pdf

Hundorova, Tamara. 2012. "Post-Chornobyl': Katastrofiinyi symptom v suchasnyi kul'turi" [Post-Chornobyl: The catastrophic symptoms in contemporary culture]. Accessed June 25, 2018. https://www.academia.edu/7297290/

Hundorova, Tamara. 2013. Postchornobyl's'ka biblioteka: Ukrains'kyi literaturnyi postmodernizm [The post-Chornobyl library: The Ukrainian literary postmodernism] Kyiv: Krytyka.

Iavorinskyi, Volodymyr. 1988. Mariia z polynom u kintsi stolittia [Mary with wormwood at the end of the century]. Kyiv: Radzians'kyi pys'mennyk.

Iovenko, Svitlana. 2016. Zhinka v zoni [A woman in the Zone]. Kyiv: Ukr. Propileyi (First published 1996).

Kennedy, Michael D. 1997. "Post Soviet Identity and Environmental Problems in Transition: Estonia, Ukraine and Uzbekistan Through Focus Groups.” Accessed January 5, 2018. https://www.ucis.pitt.edu/nceeer/1997-812-11-Kennedy.pdf

Kolesnikov, Mikhail. 2013. 'O sootnoshenii poniatii 'ekologicheskaia kul'tura' i 'ekologicheskaia kompetentnost'", [On relations between the concepts of "ecological culture" and "ecological competence"]. Vestnik Mezhdunarodnoi akademii nauk 1: 69-72. Accessed June 25, 2018. http://www.heraldrsias.ru/download/ articles/13_Kolesnikov.pdf

Korzeniowska-Bihun, Anna. 2017. “Zona czarnobylska we współczesnej dramaturgii ukraińskiej" [The Chernobyl Zone in contemporary Ukrainian dramaturgy]. In Teatr historii lokalnych w Europie Środkowej, edited by Ewa Wąchocka, Dorota Fox, and Aneta Głowacka, 212-22. Katowice: Wydawnictwo Uniwersytetu Śląskiego. Accessed January 4, 2018. http://docplayer.pl/58774161-Zona-czarnobylska-wewspolczesnej-dramaturgii-ukrainskiej.html

Leopold, Aldo. 1949. A Sand County Almanac. New York: Oxford University Press. Light, Andrew. 2007. "What Is an Ecological Identity?" Environmental Politics 9 (4): 59-81.

Mannetti, Lucia, Antonio Pierro, and Stefano Livi. 2004. "Recycling: Planned and Self-Expressive Behaviour.” Journal of Environmental Psychology 24 (2): 227-36.

Neumann, Iver. 1999. Uses of the Other: "The East” in European Identity Formation. Minneapolis: Minnesota University Press.

Oliinyk, Borys. 1988. Sim. Kyiv: Radzians'kyi pys'mennyk.

Oyserman, Daphna, Kirsten Elmore, and George Smith. 2012. "Self, Self-Concept, and Identity." In The Handbook of Self and Identity, edited by Mark R. Leary, 69-104. New York: The Guilford Press. Accessed June 19, 2018. https://dornsife.usc.edu/ assets/sites/782/docs/handbook_of_self_and_identity_-_second_edition_-_ch._4 pp._69-104_38_pages.pdf

Plokhy, Serhii. 2018. Chernobyl: The History of a Nuclear Catastrophe. New York: Basic Books.

Prévot, Anne-Caroline, Susan D. Clayton, and Raphael Mathevet. 2018. "The Relationship of Childhood Upbringing and University Degree Program to 


\section{LITERARY CHERNOBYL AS A FACTOR OF ECOLOGICAL IDENTITY...}

Environmental Identity: Experience in Nature Matters.” Environmental Education Research 24 (2): 263-79.

Roszak, Theodore, Mary E. Gomes, and Allen D. Kanner, eds. 1995. Eco-Psychology: Restoring the Earth, Healing the Mind. San Francisco: Sierra Club

Rumelili, Bahar. 2004. "Constructing Identity and Relating to Difference: Understanding the EU's Mode of Differentiation." Review of International Studies 30 (1): 27-47.

Schultz, Wesley P., Chris Shriver, Jennifer J. Tabanico, and Azar M. Khazian. 2004. "Implicit Connections with Nature." Journal of Environmental Psychology 4 (1): 31-42.

Seed, John, Joanna Macy, Arne Naess, and Pat Fleming, eds. 1988. Thinking Like a Mountain: Towards a Council of All Beings. Philadelphia: New Society Publishers. Accessed June 16, 2018. http://www.morning-earth.org/DE6103/Read\%20DE/ Beyond\%20anthropo.seed.pdf

Shcherbak, Iurii. 1986. Prychyny i naslidky [Causes and effects]. Kyiv: Dnipro.

Shcherbak, Iurii. 1989. Chornobyl' [Chernobyl]. Kyiv: Dnipro

Sparks, Paul, and Richard Shepherd. 1992. "Self-Identity and the Theory of Planned Behavior: Assessing the Role of Identification with Green Consumerism." Social Psychology Quarterly 55 (4): 388-99.

Stets, Jan, and Chris Biga. 2003. "Bringing Identity Theory into Environmental Sociology." Sociological Theory 21 (4): 398-423. Accessed June 15, 2018. http:// citeseerx.ist.psu.edu/viewdoc/download?doi=10.1.1.433.2864\&rep=rep1\&type=pdf

Sukhenko, Inna. 2014. "Reconsidering the Eco-Imperatives of Ukrainian Consciousness: An Introduction to Ukrainian Environmental Literature." In Ecoambiguity, Community, and Development: Toward a Politicized Ecocriticism, edited by Scott Slovic, Swarnalatha Rangarajan, and Vidya Sarveswaran, 113-30. Lanham: Lexington Books.

Swimme, Brian, and Thomas Berry. 1992. The Universe Story: From the Primordial Flaring Forth to the Ecozoic Era. San Francisco: Harper.

Tahlina, Iuliia. 2004. "Natsional'nyi kharakter ukrains'koho etnosu ta ioho vplyv na ekolohichnu kul'turu" [The national character of the Ukrainian ethnos and its impact on the ecological culture]. Visnyk Kharkivskoho natsional'noho universytetu imeni V. Karazina: Seriia Filosofs 'ki perepetii 638: 38-42.

Tereshina, Marina, and Igor Bashmakov. 2017. 'Ekologicheskaia identichnost' mestnykh soobshchestv kak resurs razvitiiia 'zelionoi ekonimiki'" [Ecological identity of local communities as a resource of "green" economy development]. Chelovek: Soobshchestvo: Upravleniie 18 (1): 6-16. Accessed January 4, 2018. https://elibrary.ru/item.asp?id=29906387

Thomashow, Mitchell. 1995. Ecological Identity: Becoming a Reflective Environmentalist. Cambridge, MA: MIT Press.

Tishler, Jennifer. 2006. "Identity and Meaning: Chernobyl and Literature." In Chernobyl: The Event and Its Aftermath, edited by Leonard Berkowitz, 88-113. Milwaukee: HenschelHAUS Publishing.

Verhagen, Frans. 2010. "Ecological Identity: Creating Sustainable Communities.” Earth and Peace Education International, May. Accessed January 4, 2018. http://www. globalepe.org/article_print.php?aid=23 


\section{Inna Sukhenko}

Viryna, Lidiia. 1989. Tiiei vohnianoi nochi: Chornobyl's 'ka opovid' [Shadows of a fiery night: A Chernobyl tale]. Kyiv: Molod'.

Walton, Tobin N., and Robert E. Jones. 2017. "Ecological Identity: The Development and Assessment of a Measurement Scale." Environment and Behavior 50 (6): 657-89.

Wanner, Catherine. 1998. Burden of Dreams: History and Identity in Post-Soviet Ukraine. University Park: Pennsylvania State University Press.

White, Damian F. 2010. Technonatures: Environments, Technologies, Spaces, and Places in the Twenty-First Century. Waterloo: Wilfrid Laurier University Press. 


\section{Natalia Andriichuk}

ORCID 0000-0001-8194-5417

Zhytomyr Polytechnic State University

\section{TERMINOLOGY IN INCLUSIVE EDUCATION: ITS EVALUATION IN UKRAINE}

The key words in the title above are inclusive education. It would therefore be obvious to start with the questions: Why inclusive education? What is so important about it? Why is inclusion being talked about so widely in the educational, psychological, social, sociological, jurisdictional, political, and economic fields? Inclusion is supposed to be implemented and supported both on international and national levels. Moreover, it cannot exist without the support of the local government and community. Only on condition of interrelation of all the above-mentioned structures can inclusive education work at school. Otherwise, it becomes a challenge first of all for those who are involved in the process.

It is obvious that when we talk about inclusion we cannot but talk about human rights and the rights of children. Hence, it is worth mentioning some of the main documents which regulate the right to education for every child in the world: UN Convention on the Rights of the Child (1989), 
UN Standard Rules on the Equalization of Opportunities for Persons with Disabilities (1993), Salamanca Statement - for Action on Special Needs Education: Access and Quality (1994), and UN Convention on the Rights of People with Disabilities (2006). These issues have also been widely discussed at international conferences and forums: World Conference on Education for All (EFA) by the Year 2000 in Jomtien, Thailand (1990), World Education Forum, Dakar, Senegal (2000), and others.

Here we can qoute some articles endorsing inclusive education from the documents mentioned above. The UN Convention on the Rights of the Child (Convention 1989) says in its articles that children should have equal rights regardless of race, color, sex, language, religion, political or other opinion, property, national, ethnic or social origin, disability, birth, or other status. They should have the right to quality education, to the development of their personality, talents and mental and physical abilities, respect for their own cultural and national values; disabled children should have access to education which recognizes their need for special care and assistance. The Salamanca Statement on access to and quality of special needs education states:

... schools should accommodate all children regardless of their physical, intellectual, social, linguistic or other conditions. This should include disabled and gifted children, street and working children, children from remote or nomadic populations, children from linguistic, ethnic, or cultural minorities and children from other disadvantaged or marginalized areas and groups (UNESCO 1994a, paragraph 2). 


\section{Inclusive schools are}

the most effective means of combating discriminatory attitudes, creating welcoming communities, building an inclusive society and achieving education for all; moreover, they provide an effective education to the majority of children and improve the efficiency and ultimately the costeffectiveness of the entire education system (UNESCO 1994b, paragraph 3).

The signees of the UN Convention on the Rights of Persons with Disabilities (2006), in Article 24, devoted to education, vow to ensure that all disabled children and young people

can access an inclusive, quality, free primary and secondary education on an equal basis with others in the communities in which they live. [Support should be provided] within the general education system, to facilitate their effective education. ... The education of ... children who are blind, deaf and deafblind is delivered in the most appropriate languages and modes and means of communication for the individual, and in environments which maximize academic and social development (Convention 2006).

Drawing on these notions, a 2005 UNESCO definition of inclusive education reads,

Inclusive education starts from the belief that the right to education is a basic human right and the foundation for a more just society. Inclusive education takes the Education for All (EFA) agenda forward by finding ways of enabling schools to serve all children in their communities. ... Inclusive education is concerned with all learners, with a focus on those who have traditionally been excluded from educational opportunities such as learners with special needs and disabilities, children from ethnic and linguistic minorities (UNESCO 2005).

The topicality of the problem of inclusive education implementation lies in simple yet vital things: every child has the right to live free from discrimination, to get proper education, to be healthy, to stay safe, to enjoy life, and to achieve his or 


\section{Natalia Andriichuk}

her potential, making a positive contribution. We cannot decide for the child whether he or she is good or healthy enough to go to that particular school. The child him- or herself should have an opportunity to select the school where he or she wants to study and to participate in extracurricular activities of his or her choice. Inclusion is not about where the child is taught. It is about the quality of a child's experience of school life, including both the formal and informal curriculum, in and beyond the classroom. The concept of difference is one of the distinctive values in the schooling of all children in one educational environment.

Inclusion doesn't mean socializing only those who suffer 364 from physical impairment or mental handicap, who are visually or sensory impaired. In the global context we can also talk about emigrants who do not speak the local language well enough to progress alongside other children in the class. The problem of teaching emigrants might not be of current interest for developing countries but even some of them are nevertheless making progress in the implementation of inclusive education for children with special needs in the general system of education.

It is clear that the development of inclusive education depends on the economic prosperity of a country. The implementation of inclusive education demands not only adjusting the school buildings and buying special equipment but also staff training and thorough psychological work with the schoolchildren and their parents. This does not mean, however, that only countries with developed economy can afford inclusive 
education. It is not about prestige, it is about necessity for every country and every school. Of course, developed countries have larger experience in the implementation of inclusive education, and our primary target is to use this global experience in inclusive education implementation to work out local models of inclusion.

In liberal arts, a wide range of terms, categories, definitions, notions and concepts which comprise the terminological field of inclusive education are used simultaneously: disability, a person with disability, people with functional limitations or deviations, children with special educational needs, inclusion, integration, segregation, mainstreaming, and so on.

Of these, the most widely used term is "person with disability," describing an individual who has a permanent disorder of body functions, which can be caused by illness or trauma as well as by congenital mental or physical malformations. Such individuals may require assistance and intense social care due to their disabilities. Moreover, disability can be viewed as an impairment that results in restrictions on an individual's ability to participate in what is considered "normal" in their everyday life with regard to their age, gender, social and cultural activities. Consequently, there have to be laws and regulations which ensure their social welfare and the enforcement of their rights. It is due to this association with the securing of rights that the terms "a person with disability" and "disability" are considered more politically correct than "invalid" and "invalidity," which are currently seldom used both in everyday life and academic works. 
However, to create a comprehensive general glossary of key terms in inclusive education requires studying them at different levels, looking at what definitions they have in reference guides and encyclopedias; how they are researched by scientists in their monographs, articles, and other scientific papers; finally, at how these terms are treated on the websites of the non-governmental organizations which promote application of inclusive education in comprehensive schools. Table 1 shows the major terms used in inclusive education.

TABLE 1. TERMINOLOGY IN INCLUSIVE EDUCATION

\begin{tabular}{|l|l|l|}
\hline \multicolumn{1}{|c|}{ Individuals } & \multicolumn{1}{c|}{ Processes } & \multicolumn{1}{c|}{ Conditions } \\
\hline - Disabled person & - Inclusion & - ICP (infantile cerebral \\
- People with functional & - Segregation & \multicolumn{1}{c|}{ paralysis) } \\
limitations & - Integration & - Down Syndrome \\
- Children with special & - Mainstreaming & - Autism \\
educational needs & - Assistance & - Dyslexia \\
- Invalid & - Support & - Sensory impairment \\
- Cripple & - Interaction & - Visual impairment \\
- Handicapped & - Promotion & - Mental retardation \\
- (Physically) challenged person & - Practice & - Social disadvantage \\
- Person with disabilities & & - Physical impairment \\
& & - Mental handicap \\
\hline
\end{tabular}

The key terms used in the sphere of inclusive education, however, have been: "educationally subnormal" (a term not used in the UK after the 1970s); "moderate learning difficulties (MLD)"; "retarded" or "mentally retarded" (it is now replaced with a new term, "learning and cognition needs") and "special educational needs (SEN)." The latter term is a legal definition which is used nowadays for the children who have learning difficulties or disabilities that make it harder for them to learn 
than for most children of the same age. These children may need extra help or help that is different from that given to their peers.

Additionally, the discourse in which the terms are used should be taken into account, as well. The latter defines the contextual peculiarities of the formation, creation, perception, and circulation of specialized texts, although these parameters may vary in different cultures. Most texts with inclusive education as their subject matter are systemic products, in that the state system itself assigns all essential parameters to each text. For instance, the form of some "restricted" texts has been defined by the system a while ago and in some cases has not changed one bit. If the form does undergo certain changes, it is usually caused by efforts of the people involved, rather than by the impact of the system. Modern semasiology pays much attention to the notion of discourse, defining the term as a social and linguistic structure, which is recreated by the addressee in specific communicative, social, and pragmatic situations.

The term "discourse" can be taken to mean one of three things: people's communicative activity and its pragmatic aspects (oral communication above all things); oral and written communication; the universe of texts, customs, traditions, rules and norms of a certain language and culture. Taking into account the discourses in which the conceptual and categorical framework of inclusive education is used in original texts presupposes different ways of interpretation of the terms used therein. Analysis and systematization of the terms, as predefined by the project, should be carried out at the levels of semasiology, linguistics (i.e., vocabulary, grammar, and style), 
as well as through the study of pragmatic relations between lexical units.

The research methodology postulated combines semasiology (aiming at linguistic analysis of modern inclusive terminology) and comparative linguistics (comparative analysis of terminological constructions in different linguistic environments), as well as the theory and practice of inclusive education (the use of semantic and pragmatic methodology to create a Ukrainian terminology for inclusive education). The main peculiarity of this methodology lies in its interdisciplinary character on the one hand, and the integration of applied research methods on the other hand. The following methods and techniques should 368 be used within the scope of the chosen methodology: content analysis of multilingual texts with the help of dictionaries and reference literature, including especially regulatory and legal documents from different countries; comparative analysis of notions (based on the findings obtained from the content analysis) and modelling (creation of the terminological model of inclusive education in the Ukrainian language).

The theory and methodology of inclusive education is a comparatively young branch of pedagogical sciences in Ukraine, although it has already piqued the interest of Ukrainian scientists. The novelty of this field makes it essential to study the terminology therein, as well as to systematize its common and distinctive features from the viewpoint of comparative linguistics. For the time being, in Ukraine the basic terminological units in the sphere of inclusive education (see table 1) are transplanted in their entirety from the English language and more often 
than not preserve the meanings of their English counterparts. However, they can change their connotation to a certain degree, though it usually depends on the discourse they are used in. This is especially obvious with the names of the processes. Inclusive education becomes gradually available to the general public in Ukraine. That is why considerable public effort goes into its organization on different stages of education. Moreover, legal and regulatory framework is created as well, complemented by theoretical and methodological grounds for its implementation. Thus, the creation and systematization of the conceptual and categorical framework, and its comparative analysis from the linguistic point of view, as well as the justification and practical approbation of the specific methodological complex for the provision of inclusive education services in Ukraine, serve as means to harmonize the theory and practice of inclusive education in the scientific, theoretical, social, legal, and regulatory spheres. The experience of applying terminology accumulated so far in the theory and practice of inclusive education in different educational systems gives the opportunity to coordinate and allocate potential resources of the Ukrainian system of education taking into account the general semantic environment in different countries of the world.

In their review of 28 European countries, Col Meijer, Victoria Soriano, and Amanda Watkins described three different approaches to including pupils with special educational needs in education. These are:

- one-track approach: the one-track approach occurs in the countries which have developed policies headed towards 
the inclusion of almost all pupils within mainstream education. Such kind of education is supported by a wide range of activities focusing on the mainstream school;

- two-track approach: two separate education systems exist within the country. Children with special educational needs usually study in special schools or special classes. In practice, the majority of pupils officially registered as those who have special educational needs do not follow the mainstream curriculum along with their non-disabled peers. These systems are usually under separate legislation, with different laws for mainstream and special needs education;

- multi-track approach: those countries which subscribe to the multi-track approach have a vast range of approaches to inclusion. They offer various services for both the mainstream and special needs education system (Meijer, Soriano, and Watkins 2003).

For the last few years, Ukraine has been trying to fully implement inclusive education. According to the plan, all children with special needs should have been placed in the mainstream education. But the reality is that most children with special needs are still outsiders. A very small percentage of such children study together with their peers. Special schools for disabled children in Ukraine still exist and a vast majority of these children get education there. Over the course of the last several years, however, special classes have started to open in mainstream schools. Moreover, there is another form of education, called individual form of learning, whereby pupils with 
special needs study at home. Thus, Ukraine can be referred to the two-track approach to offering schooling to special needs children. Another key feature of the Ukrainian national policy on inclusive education to consider is that schools prefer to hire psychologists as assistants. This can be explained by psychologists being more educated in the sphere of working with special needs children than teachers.

It should be mentioned that the situation of inclusive education in Ukraine is slowly improving. Ukraine is now at the crossroads between special and inclusive education. Of course, some politicians affiliate themselves with the cause and in doing so use their influence to promote wide implementation of inclusive education in the country. For instance, Maryna Poroshenko, the former First Lady, was a champion of the inclusive form of education. Due to this patronage, schools received more opportunities to provide children with special needs with all the necessary materials to fully socialize and integrate them in the society.

As for the financial support, schools that teach children with special needs receive a subvention (23,000 UAH for each child with special needs per year) to pay for additional education services and the necessary materials. Every child is invited before a PMPC (Psychological Medical Pedagogical Commission), where his or her situation is assessed by specialists (including a psychiatrist, defectologist, speech therapist, psychologist specializing in intellectual development, psychologist specializing in deviant behavior, and correctional teacher). In 2018, plans were introduced to open a network of Inclusive Resource Centers. 
Apart from the work that has already been done to fully implement inclusive education in the general education system, there are lots of initiatives which need immediate intervention: special training for teachers on how to work in inclusive education should be conducted. In this connection, the problem which was raised in this article (i.e., the creation of a common terminological field) is becoming of special importance. Moreover, the readiness of both parents and teachers to engage themselves and their charges in inclusive education can be achieved by familiarizing them with the system of notions and values significant for inclusion. And finally, the number of teachers who partake in inclusive education and work with special needs students should be increased. To these ends, more centers for teacher preparation should be created, along with more resource centers for students and especially for their parents, which would provide psychological, practical, and medical help.

\section{REFERENCES}

Convention. 1989. Convention on the Rights of the Child: Adopted and opened for signature, ratification and accession by General Assembly resolution 44/25 of 20 November, 1989. Accessed July 8, 2018. https://www.ohchr.org/Documents/ ProfessionalInterest/crc.pdf

Convention. 2006. Convention on the Rights of Persons with Disabilities and Optional Protocol. Accessed July 8, 2018. http://www.un.org/disabilities/documents/convention/convoptprot-e.pdf

Meijer, Col, Victoria Soriano, and Amanda Watkins. 2003. "Special Needs Education in Europe: Inclusive Policies and Practices.” In Col Meijer, Victoria Soriano and Amanda Watkins, Special Needs Education in Europe: Thematic Publication, 7-18. Middelfart: European Agency for Development in Special Needs Education. UNESCO. 1994a. The Salamanca Statement and Framework for Action on Special Need Education: Adopted by the World Conference on Special Needs Education, Salamanca, Spain, 7-10 June 1994. Paris: Unesco; Madrid: Ministry of Education 


\section{TERMINOLOGY IN INCLUSIVE EDUCATION}

and Science of Spain. Accessed July 8, 2018. http://www.unesco.org/education/ pdf/SALAMA_E.PDF

UNESCO. 1994b. The Salamanca Statement and Framework for Action on Special Needs Education: World Conference on Special Needs Education: Access and Quality, Salamanca, Spain, 7-10 June 1994. Paris: Unesco; Madrid: Ministry of Education and Science of Spain. Accessed July 8, 2018. https://www.europeanagency.org/sites/default/files/salamanca-statement-and-framework.pdf

UNESCO. 2005. Guidelines for Inclusion: Ensuring Access to Education for All. Paris: UNESCO. Accessed July 8, 2018. http://unesdoc.unesco.org/images/ 0014/001402/140224e.pdf 


\section{ABOUT THE AUTHORS}

\section{Natalia Andriichuk, $\mathrm{PhD}$}

Faculty of Public Administration and Law, Zhytomyr Polytechnic State University

andrnata1977@gmail.com

https://orcid.org/0000-0001-8194-5417

\section{Daria Burnasheva, $\mathrm{PhD}$}

Department of Folk and Traditional Arts, Arctic State Institute of Culture and Arts, Yakutsk dv.burnasheva@agiki.ru https://orcid.org/0000-0002-2029-6115

Wojciech Cendrowski, $\mathrm{PhD}$ Candidate Faculty of "Artes Liberales," University of Warsaw w.cendrowski@al.uw.edu.pl https://orcid.org/0000-0002-1884-3386 


\section{ABOUT THE AUTHORS}

\section{Bato Dondukov, $\mathrm{PhD}$}

Department of Organization and Management of Scientific Researches, East Siberia State University of Technology and Management, Ulan-Ude dondukovb@gmail.com https://orcid.org/0000-0001-5501-9858

\section{Galina Dondukova, $\mathrm{PhD}$}

Department of Organization and Management of Scientific Researches, East Siberia State University of Technology and Management, Ulan-Ude galina.dondukova11@gmail.com https://orcid.org/0000-0002-4390-7556

\section{Jan Kieniewicz, Professor}

Faculty of "Artes Liberales," University of Warsaw jotka8@gmail.com https://orcid.org/0000-0002-3580-9112

\section{Irina Koluzaeva, $\mathrm{PhD}$}

Faculty of "Artes Liberales," University of Warsaw ira.koluzaeva@gmail.com https://orcid.org/0000-0002-2685-4288

\section{Valeria Korablyova, $\mathrm{ScD}$}

Department of Russian and East European Studies, Charles University, Prague valeriya.korablyova@fsv.cuni.cz https://orcid.org/0000-0003-4523-7557 
Marzena Maciulewicz, $\mathrm{PhD}$

Faculty of "Artes Liberales," University of Warsaw;

Institute of Slavic Studies, Polish Academy of Sciences, Warsaw ma.maciulewicz@gmail.com

https://orcid.org/0000-0002-7704-1412

Oleksiy Polunin, ScD, Professor

Department of Psychology, Kyiv National University of Trade and Economics

polunin.oleksiy@gmail.com

https://orcid.org/0000-0001-9058-3200

\section{Robert Sucharski, Professor}

Faculty of "Artes Liberales," University of Warsaw

sucharsk@al.uw.edu.pl

https://orcid.org/0000-0001-7708-7173

\section{Inna Sukhenko, $\mathrm{PhD}$}

Oles Honchar Dnipro National University

inna_suhenko@ukr.net

https://orcid.org/0000-0003-1295-2271

\section{Kyunney Takasaeva (Künnej Takaahaj), $\mathrm{PhD}$}

Faculty of "Artes Liberales," University of Warsaw kunnej@gmail.com https://orcid.org/0000-0002-1383-9206 


\section{ABOUT THE AUTHORS}

\section{Olha Tkachenko, $\mathrm{PhD}$}

Faculty of "Artes Liberales," University of Warsaw;

Institute of Slavic Studies, Polish Academy of Sciences, Warsaw o.tkachenko@al.uw.edu.pl https://orcid.org/0000-0002-0777-7897

\section{Kamil Maria Wielecki, $\mathrm{PhD}$}

Faculty of "Artes Liberales," University of Warsaw

kamil.wielecki@al.uw.edu.pl

https://orcid.org/0000-0003-0211-9884

\section{Ayur Zhanaev, $\mathrm{PhD}$}

Institute of Social Prevention and Resocialization, University

of Warsaw

a.zhanaev@uw.edu.pl

https://orcid.org/0000-0002-8976-8811 


\section{LIBALMONOGRAPHS}

VOLUMEIV

This volume is dedicated to the International PhD Program "Searching for Identity: Global Challenges, Local Traditions," organized at the Faculty of "Artes Liberales" of the University of Warsaw, in 2013-2018. The volume aims at showing identity as a processual concept, using the example of the researcher as a living personality. It thus corresponds with the general trend in the humanities and social sciences to pay attention to the researcher and the ways his or her personal background and experience influence the generation of knowledge. By introducing this topic, we would like to show completing a $\mathrm{PhD}$, or any other research, as a dynamic process with a personal history of success and failure, as well as to demonstrate the impact of the "Searching for Identity" project. 